Universidade de São Paulo

Roberto de Barros Freire

\title{
Participação política como exercício de cidadania
}

\author{
Trabalho apresentado como exigência para \\ Defesa de Tese no Programa de Pós-graduação \\ em Filosofia da Faculdade de Filosofia, Letras \\ e Ciências Humanas, da Universidade de São \\ Paulo, em nível de doutorado, sob orientação \\ do Prof. Dr. Renato Janine Ribeiro.
}

\section{Bolsa: CAPES/PQI \\ e-mail: rdefreire@uol.com.br}

São Paulo

Dezembro de 2006 
Universidade de São Paulo

Roberto de Barros Freire

\section{Participação política como exercício de cidadania}

São Paulo

Dezembro de 2006 


\section{DEDICATÓRIA}

Dedico este trabalho a Cris, a mais humana das figuras humanas que conheço, que sempre me suportou e suporta, por saber dos defeitos humanos através de mim. A ela, representando a humanidade, está este trabalho dedicado. 


\section{AGRADECIMENTOS}

Agradeço primeiramente ao Departamento de Filosofia da Universidade Federal de Mato Grosso, que permitiu meu afastamento para realização deste trabalho, assumindo meus encargos. Agradeço a UFMT, em particular à Pró-Reitoria de Pós-Graduação, que não mediu esforços para a minha qualificação, de onde obtive todo apoio solicitado. Agradeço a Renato Janine Ribeiro, orientador, que confiou em mim e deu toda liberdade na realização do trabalho: todos os méritos são dele, os deméritos são inteiramente meus. Quem tiver paciência de ler meu trabalho e conhecer o trabalho de Renato, verá que devo muito a ele, que incorporei muitas de suas reflexões que fui compartilhando no decorrer de discussões no seu grupo de pesquisa sobre poder e na leitura de seus textos. Agradeço a Ari Ricardo Tank Brito, mais que amigo, um sábio e enciclopédico conselheiro, com o qual fui levado a pensar sob a ótica de novos pensadores que ele me apresentou, em particular Mandeville. Agradeço aos professores Maria das Graça de Souza e Sergio Cardoso que tão dedicadamente e confiantemente abraçaram o projeto de capacitação no Departamento de Filosofia da USP, e estão contribuindo não só com este trabalho, mas com o projeto mais amplo do Departamento de Filosofia da UFMT, o CAPES/PQI-20. O contato com ambos, a força que eles estão dando a mim e ao Departamento de Filosofia da UFMT, foi um prêmio extra ao trabalho de doutoramento. Agradeço aos membros da banca de minha qualificação, novamente a professora Maria das Graças Souza e o professor Milton Meira Nascimento (além do Renato, é claro, como orientador) pela contribuição que suas argüições promoveram. Por fim, mas não me nos importante, agradeço a CAPES pelo financiamento da minha pesquisa, que permitiu condições mais apropriadas para a realização do trabalho, assim como participar de diversos eventos acadêmicos tão necessários para exposição e debate dos estudos. 


\title{
Resumo
}

Dentre as diversas formas de abordar a participação política, uma em particular chama atenção: a ocorrência de uma acentuada alienação política ou uma crescente apatia pela cidadania ativa. Nesta perspectiva, a abordagem do problema político se fará do ponto de vista do indivíduo diante de condições instituintes de ordens sociais, porém, maleáveis a ações humanas intencionadas. A política não será entendida tão somente como jogo de forças sociais e interesses, mas também como busca negociada de interesses particulares visando o bem comum, como produto de um consenso possível. $\mathrm{O}$ foco principal da política está no exercício da cidadania, podendo ocorrer de forma mais ou menos consciente, o que permite qualificar a ação política como mais ou menos ética. Ao fim, estabelece a política como chamamento para a atividade consciente e ativa, objetivando fazer cidadãos participativos.

Palavras Chave : Filosofia. Participação política. República. Ética. Cidadania.

\begin{abstract}
Amongst the many possible ways that are of approaching the political participation, one calls more attention: the occurrence of an accentuated political alienation, or a crescent apathy for the active citizenship. Under this perspective, the approach to the political question will be made from the point of view of the individual before the institutional conditions of the social orders, malleable to intentional human actions. Politics, then, is not to be understood just as a game of social interests and forces, but as a negotiated search of the particulars interests meaning the common good, as a product of a possible consensus. The principal focus of the politics is in the exercise of the citizenship, and that can occur with some degree of awareness, justly what permit to designate the political action as more or less ethical. In the end, the politics is established as a calling for an active and conscientious activity, made by participative citizens.
\end{abstract}

Keywords : Philosophy. Political participation. Republic. Ethic. Citizenship. 
1. Introdução

2. Parte 1: Um Animal Político? 24

3. 1.1 - Uma Genealogia da Política 37

4. 1.2 - Sobre o Governo 46

5. 1.3 - Uma Política de Massas $\quad 60$

6. Parte 2: Um Ideal de República 70

7.2.1 - Aspectos da República Contemporânea 84

8.2.2 - Promessas Republicanas em Práticas Democráticas 99

9. Parte 3: Decorrências Práticas: uma política de longo prazo 107

10. 3.1 - Da Liberdade à Violência 109

11.3.2 - Uma Ética para a Cidadania $\quad 132$

12.3.3 -Do Fim ao Começo Sem Fim 151

16. Referências 166 


\section{INTRODUÇÃO}

Não é quando é perigoso dizer a verdade que ela raramente encontra defensores, mas sim quando é enfadonho. Nietzsche 
Como atingir uma unidade entre os interesses da cidade e os de seus cidadãos enquanto indivíduos? Podemos dizer que na evolução da teoria política, houve duas principais linhas de abordagem desse tema. Uma delas afirma que o governo será eficiente sempre que suas instituições forem fortes e corruptos sempre que seu maquinário não conseguir funcionar adequadamente. A outra linha entende, ao contrário, que se os homens que controlam as instituições governamentais forem corruptos, as melhores instituições possíveis não terão como molda-los ou refreá-los, enquanto se forem eles virtuosos, a qualidade das instituições se tornará um tópico de menor importância. Não é tanto o maquinário do governo, mas o próprio espírito dos governantes, do povo e das leis o que mais precisa ser focado. Sem dúvida, como se perceberá, essa tese está engajada nessa última linha.

Ela parte de um princípio elementar: para existir a ação política basta estar vivo. Existir é em si um fato político. Mas, para haver participação política consciente, ou seja, perceber a ação conjugada dos homens e agir em conjunto pelo bem comum, o que importa é a atitude criativa, daquele que se torna sujeito de sua vida, e não mais o lugar de onde vem: a postura, e não a posição, eis o que conta. Ser condutor de sua vida, estadista do seu destino é o desafio para cada pessoa.

Ora, como bem coloca Hannah Arendt no seu livro A Condição Humana, aquilo que faz do homem um ser político é sua faculdade para a ação; ela o capacita a reunir-se a seus pares, agir em conjunto e almejar objetivos e empreendimentos que jamais passariam por sua mente, deixando de lado alguns desejos de seu coração ao se aventurar em algo novo. A inserção no mundo humano se dá com palavras e atos, no qual confirmamos e assumimos o fato original e singular do nosso aparecimento físico original.

O ímpeto de agir vem ao mundo quando nascemos, ao qual respondemos começando algo novo por nossa iniciativa. Agir, no sentido mais geral do termo, significa tomar iniciativa, iniciar, começar, ser o primeiro, governar, imprimir movimento a alguma coisa. O fato de o homem ser capaz de agir significa que se pode esperar dele o inesperado, sendo capaz de realizar o infinitamente improvável, tanto para o bem como para o mal. E isto, por sua vez, só é possível porque cada homem é singular, de sorte que, a cada nascimento, vem ao mundo algo singularmente novo. 
Entretanto, o estabelecimento de um novo início através da ação incide sempre sobre uma teia já existente, e nela imprime suas conseqüências mais imediatas. Juntos, os homens iniciam novo processo, que mais tarde emerge como a história de vida do recémchegado, que afeta de modo singular a história de vida de todos aqueles com quem ele entra em contato. É em virtude desta teia preexistente de relações humanas, com suas inúmeras vontades e intenções conflitantes, que a ação quase sempre deixa de atingir seu objetivo; mas é também graças a esse meio, onde somente a ação é real, que ela "produz" histórias, intencionalmente ou não.

Pelo fato de que todo ator se movimenta sempre em relação a outros seres atuantes, ele nunca é simples agente, e sim ao mesmo tempo paciente. Agir e padecer são como faces opostas da mesma moeda, e a história iniciada por uma ação compõe-se de seus feitos e dos sofrimentos deles decorrentes. Estas consequiências são ilimitadas porque a ação, embora provindo do indivíduo, atua sobre um meio no qual toda reação se converte em reação em cadeia, e todo processo é causa de novos processos. Como a ação atua sobre seres que também são capazes de agir, a reação, além de ser uma resposta, é sempre uma nova ação com poder próprio de atingir e afetar os outros. Assim, a ação e a reação jamais se restringem entre os homens a um círculo fechado, e jamais podemos, com segurança, limitá-las a dois parceiros.

Além disso, seja qual for o seu conteúdo específico, a ação sempre estabelece relações, e tem, portanto, a tendência inerente de violar os limites e transpor as fronteiras. Os limites e fronteiras que existem na esfera dos negócios humanos jamais chegam a constituir estrutura capaz de resistir com segurança ao impacto com que cada nova geração vem ao mundo.

Não obstante, a ação só pode ser julgada pelo critério de grandeza, porque é de sua natureza violar os padrões consagrados e galgar o plano do extraordinário, onde as verdades da vida cotidiana perdem sua validade e é julgada por aquilo que distingue do lugar-comum e que contribui direta ou indiretamente para a construção do espaço público. A esfera pública, o espaço que os homens necessitam para aparecer, é obra do homem: é responsabilidade de ações conjugadas em esferas distintas da vida humana.

O significado mais profundo do ato praticado e da palavra enunciada independe da vitória ou da derrota, e não é afetado pelo resultado final, por suas consequiências boas ou 
más, pois a existência humana implica essencialmente aparecer, para si mesmo e para os outros. Como ser e aparecer coincidem, tendo em vista que não apenas estamos no mundo, mas somos do mundo, necessariamente vendo e sendo vistos pelos outros, gestos e vozes repercutem pelo espaço público, instituindo práticas políticas e sociais, e duram no tempo e são trazidas à recordação para ensinar os novos homens. O fato é que até a mais inofensiva das ações humanas, a atividade de pensar, delibera reflexão e juízo autônomos no domínio público, no qual aparece sempre como um cidadão entre cidadãos, lançados na aventura do espaço público.

O exercício da atividade de pensar é capaz de criar um espaço, um componente político capaz de plasmar novidades, não por estar certo, mas simplesmente por ter ousado agir. E entender o pensamento como atividade significa que pensar é pôr em movimento o diálogo dos parceiros, visando chegar a um acordo, embora, sem garantia de um resultado final, posto que o diálogo poderá ser a qualquer momento retomado ou interrompido. Significa também que o pensar é entendido como uma faculdade comum e não algo que apenas alguns podem exercitar. Qualquer pensador, não importa quão importante seja, permanece um homem, uma aparência entre aparências, dotado de senso comum e dispondo de um raciocínio de senso comum suficiente para sobreviver.

Se o mundo é plástico e está em constante mutação, quando visto do ângulo do indivíduo criativo e astucioso, ainda que a ação seja privada e egoísta, seu resultado é social, instituído por uma ação criadora - e pouco importa se esta é a do indivíduo ou do grupo. A essa ação que cria o social, cabe chamar de ação política, uma ação que assume como seu o ponto de vista da criação, e que pretende moldar ou criar o social. Há política quando nos fazemos sujeitos de uma realidade, quando não a tomamos por dada, ou por independente da ação humana, mas a concebemos como resultado dessa ação, e ainda nos propomos a agir, moldando o mundo.

Todavia, como indivíduo não elegi esse mundo; viver é encontrar-se em um mundo determinado e insubstituível, neste de agora. Mas esta fatalidade vital não se parece à alguma mecânica histórica ou natural. A fatalidade em que caí ao despencar neste mundo consiste em vez de impor-se uma trajetória, impõem-se várias, todas e nenhuma, e conseqüentemente, sou forçado a eleger. Viver é sentir-se fatalmente forçado a exercitar a 
liberdade, a decidir o que vamos ser neste mundo. Nem um só instante se deixa descansar nossa atividade de decisão, inclusive quando desesperados nos abandonamos ao que vier, decidimos não decidir.

Ocorre hoje uma estranha dualidade de prepotência e insegurança que se aninha na alma contemporânea: a vida, como repertório de possibilidades, é magnífica, exuberante, superior a todas as historicamente conhecidas. Mas, assim como seu repertório é maior, transbordou todos os caminhos, princípios, normas e ideais legados pela tradição. Temos de inventar nosso próprio destino: o passado não pode dar uma orientação positiva, só negativa; não diz o que fazer, mas o que evitar.

Os protestos que foram amplos e justificados no século $\mathrm{XX}$, um século de liberações, parece que do seu final e no início do século XXI se reduz a uma reclamação, a uma queixa retórica e lamuriosa cujo principal efeito é o de constituir uma estranha figura de pessoas infantilizadas. Não é incomum o protesto resultar simplesmente de desconhecimento e alheamento em face de ações que poderiam ter sido tomadas, e não foram, pelo próprio reclamante. A relação política assume o modelo do cliente com o despachante, ou seja, o representante se converte em alguém que presta serviço de ordem privada a seu representado. Mas o tempo da mera reclamação passou, e infelizmente muitos dentre os contemporâneos ainda não notaram e não sabem que uso fazer da liberdade, da democracia: talvez seja essa uma das pequenas tragédias que assolam o mundo.

Em grande número de Estados contemporâneos, a legitimidade proclamada é de tipo democrático, ao passo que a aparência política confere o poder a uma espécie de monarca temporário e o funcionamento político real é de tipo oligárquico. Um Estado gerente da sociedade - as gerências são silenciosas, as grandes vozes se calam, tudo se passa como se, na ordem política, os princípios tivessem se tornado objeto de tão grande consenso que podem dispensar as doutrinas e os grandes debates. Às instituições assegura-se o funcionamento regular e sua louvação é até exagerada, como se não se tratasse de construções históricas. A política é oligarquizada pelos partidos e os governos tornam-se mais e mais opacos. Decisões cruciais que dizem respeito à macroeconomia e, embora não pareçam, à vida cotidiana dos cidadãos e eleitores, correm por fora das instituições da representação popular, até mesmo na sua instância máxima, que é o poder executivo. 
A questão a ser respondida nos dias atuais não é porque o povo se rebela, mas por que não o faz? Por que os homens lutam obstinadamente por sua servidão, como se ela os fosse salvar? Hoje a questão não é se ou mesmo porque existem resistência e rebelião, mas sim como determinar o inimigo contra o qual se rebelar? De fato, é a habilidade para identificar o inimigo que conduz à vontade e à ação de resistir ou agir no círculo político. Mas, desapareceram os inimigos ou os adversários, só existem concorrentes de um lado e apostadores do outro; falta entusiasmo, causa e vigor, sobra indiferença e má vontade. Assim, a questão política que precisa ser colocada não é sobre o melhor regime político, mas dos problemas que acarreta não se compreender as próprias escolhas políticas realizadas, através da apropriação indevida de categorias políticas deslocadas tanto do seu fundamento teórico como de sua prática fundante.

Ora, qualquer um pode exercer influência política nas democracias ocidentais, o problema é por que a grande maioria das pessoas abre mão dessa capacidade? A resposta é simples, ainda que bastante questionável: somos educados para ser animais sociais e não políticos! Politicamente age-se como um rebanho correndo atrás de líderes mais do que como uma sociedade ordenada sabedora dos deveres e direitos de cada um. Espera-se do Estado pelo seu pedaço de pasto, pela manutenção e garantia do mesmo, e luta-se para ter ou abocanhar mais pedaços de pastagem. A política tem deixado de ser um instrumento de instituição do comum e se torna cada vez mais uma jurisdização de direitos individuais; no lugar da igualdade, a busca pelo pessoal e coletivamente diferente dos demais: seres sociais, mas apolíticos. Mais do que uma suposta busca pela convivência comum e ética que a política permite, a busca da delimitação de espaços, direitos, deveres e regras de etiqueta que a sociedade (ou seus membros mais influentes) deseja.

A esfera da política, que era entendida como o exercício da cidadania entre iguais, hoje é percebida com uma atuação profissional que complementa as demais atividades urbanas e tem uma função social e/ou assistencialista. A atividade política do cidadão está restrita a mera obediência cívica de cumprir leis e pagar os impostos, ou, em cada vez mais lugares do mundo, depositar votos na urna. Assim, os problemas sociais e humanitários ficaram relegados a uma repartição estatal, cujos méritos ou deméritos são atribuídos aos governantes. 
Entretanto, o que mais estranho se avista na atualidade é que a responsabilidade, social e pessoal, está se tornando cada vez mais uma carga insuportável que as pessoas ao invés de carregarem, preferem delegar ou pagar alguém para que faça por si. Não reclamam as massas porque se vejam privadas de participação no Parlamento, no Executivo ou no Judiciário: o que mobiliza é a privação do que é essencial para a vida, que em nossos dias, cada vez mais, significa a falta que lhe faz algum supérfluo que se tornou essencial.

Enfim, constata-se que há fenômenos humanos contemporâneos que não cabem nas categorias do passado, e isso obriga a ser mais narrador dos eventos, do que juiz dos mesmos, tentando inutilmente classificá-los de acordo com categorias criadas e institucionalizadas num passado antigo ou recente. Basta perceber a dificuldade hoje para estabelecer o que é progressista ou o que é conservador nas políticas e nos políticos. O homem, dotado da liberdade, da racionalidade, da capacidade de instituir novidades ao mundo, cria situações inusitadas e nunca vividas, que necessitam de novas palavras para se fazerem visíveis ao contemporâneo.

Dentro desse contexto, uma limpeza de campo precisa ser realizada para que se possa acompanhar com um outro ângulo de olhar a política, o lócus onde se trava o jogo da vida humana, cujas regras se auto-institui. Ao invés de buscar o $\underline{s e r}$ da política, o intuito será salientar o estar da política como uma instituição de agentes humanos que realizam contratos, ou seja, a política não é uma substância, mas uma relação entre pessoas, algo que só existe ao se fazer e no fazer diário.

O importante é expor o modo como a humanidade se inter-relaciona no mundo atual, pois não sendo algo inato, mas sim instituído no decorrer de entendimentos diversos dos homens sobre o que é certo e justo a todos, que dão esforços distintos e recebem prêmios diversos do convívio entre si: como se realizam esses pactos ou contratos em que as pessoas reconhecem e respeitam as apropriações diferenciadas da riqueza comum, é uma temática que se impõem à discussão política.

Assim, tendo essas premissas e para dar conta desses problemas, dividi a tese em três partes. $\mathrm{Na}$ primeira parte, transcendo alguns truísmos que pensam a política como uma simples relação de domínio, numa oposição entre dominantes e dominados, que elimina de cena o consentimento voluntário para a existência dessa relação. Não há poder que funcione sem um aval daqueles que a ele obedecem: o único modo pelo qual alguém 
abre mão de sua liberdade natural e se coloca sob os grilhões da sociedade civil e do Estado é pelo mecanismo do consentimento, concordando com outros homens em se juntar e se unir numa comunidade.

Procuro mostrar que, se não permite a possibilidade de uma pura racionalidade social, a política traz como pré-requisito uma crença na razoabilidade humana, onde não são necessárias nem a força bruta da violência, nem o temor servil de forças obscurantistas sobrenaturais para convencer as pessoas ao justo e ao certo. Nessa perspectiva, faço uma distinção entre política e dominação. Há política quando se renuncia ao uso da força para impor as próprias idéias, e se admite a divergência de idéias ou ideais. Há política quando temos um espaço para tolerar quem não compartilha nossa fé religiosa, quando há um processo de laicização da vida social. Há política quando se abre mão da violência como meio de sujeitar as vontades sociais e se utiliza a fala para negociar os interesses. Existe poder político quando a ação de determinados entes sociais exerce uma certa força na sociedade, r̃o sob ameaça, chantagem, terror, etc, mas quando a política é exercida sob uma alta probabilidade de que uma ordem seja seguida por um dado grupo de pessoas, quiçá todos.

A mera dominação, por exemplo, a tirania, o despotismo, o autoritarismo, o totalitarismo, qualquer tipo de imposição sem consentimento é a morte da vida política, e a rigor nem deveria ser classificado como formas de governo ou regimes políticos, como se encontra na literatura filosófica ou das ciências políticas. Com ações violentas exercidas pelo Estado ou um tirano, não cabem atitudes políticas, apenas reações imediatas em nome da auto-sobrevivência, um imperativo que vale por si mesmo, e que mesmo Hobbes no seu Leviatã, retirando toda liberdade natural não ousou tirar essa última e derradeira, pelo menos para quem está diante de ameaça iminente de morte. Na política a coerção só é utilizada em casos limites, e a possibilidade de emprega-la obedece aos imperativos de controle social razoavelmente comungados em comum por uma sociedade.

Hoje em dia o poder é mais o controlador de forças que seu produtor e organizador, sendo apenas a instância que constitui os cidadãos como sujeitos com vontades, porém inclinando-os para que se dobrem (quase naturalmente) a suas normas e leis. Em especial, o poder político contemporâneo não é mais, essencialmente, uma instância repressiva e transcendente, mas uma instância de controle, que envolve o indivíduo mais do que o 
domina abertamente; é menos dominador, e mais manipulador; preocupa-se menos em reprimir a desobediência e mais em preveni-la, e se estrutura não apenas para punir, mas também para disciplinar. É um fato público e não alguma coisa que se adquire, se toma ou se divide, algo que se deixa escapar, acumular, doar. O poder é uma conjugação de forças e interesses numa determinada direção que é conveniente às partes, em suas multiplicidades, que pode se desfazer nas decorrências das ações. O fato significativo é que no século $\mathrm{XX}$ poder deixou de ser apenas o que está nos assuntos diretamente políticos. Poder e política vão além da dominação e uso de força ou violência, dizem respeito à criação de mundos novos, tem parte com a incompletude do mundo e torna a ação indeterminada. Esta indeterminação das coisas como condição de nossa liberdade gera também uma angústia extraordinária, típica de nosso tempo.

Nessa parte faço saliento um fato peculiar nos pensadores da política, que quase todos fogem da fragilidade dos negócios humanos para a solidez da tranqüilidade de alguma ordem governamental. Isso parece tão recomendável, que a maior parte da filosofia política, desde Platão e a sua República, pode ser interpretada como uma série de tentativas de encontrar fundamentos teóricos e meios práticos de evitar inteiramente a política. O que caracteriza todas essas formas de evasão é o conceito de governo, isto é, a noção de que os homens só podem viver juntos, de maneira legítima e política, quando alguns têm o direito de comandar e os demais são obrigados (forçados?) a obedecer. A noção vulgar de que toda comunidade política consiste em governantes e governados baseia-se na suspeita em relação à ação e resulta do sincero desejo de encontrar um substituto para a ação livre dos indivíduos, sempre suscetível de se submeter a alguma atitude irresponsável ou tirânica. Visível e notório é que todos os autores (considerados sérios, é claro) concordam que a necessidade de liderança política é axiomática; o problema sempre é saber quais os tipos de lideranças são boas e quais são más.

Por fim, ainda nessa primeira parte, proponho um olhar para uma política de massas com perspectivas internacionalistas. O princípio político que deve guiar a atividade política e legisladora é a idéia de humanidade. Ora, o evento político decisivo de nossa época é a emergência da humanidade de sua existência puramente espiritual, como um sonho utópico, uma categoria ou um princípio diretor, para configurar uma realidade política urgente e sempre presente nos dias atuais, o que obriga a buscar um fundamento adequado para um 
corpo político mundial para comportar a infinidade de individualidades e grupos que coabitam esse mundo, e que já não se enquadram dentro de fronteiras definidas. Uma atitude adequada nessa situação planetária é a comunicação ilimitada, o que implica fé na compreensibilidade de todas as verdades e boa vontade para revelar e escutar como condições primeiras de uma autêntica convivência humana. A tecnologia já permite isso, falta a "vontade" política para por em prática.

Ser um homem de boa vontade significa estar interessado não apenas na paz ou na obediência às leis existentes, mas na própria atividade legisladora e na pacificação do mundo. E para tanto é necessário pensar não numa luta irreconciliável de interesses, ou do bem contra o mal, no contexto moderno há que se substituir os sacrifícios cegos e as virtudes instintivas daqueles poucos do passado pelas luzes do cálculo dos muitos do presente. Não é tanto a virtude que precisa ser grande, mas a tentação que tem que ser pequena. Não é o desapego aos interesses que tem que ser buscado, é o interesse que tem que ser bem compreendido. O problema do homem não é a sua falta de boa vontade, mas o não saber de que forma implementar suas reivindicações, como definir prioridades num conflito entre bens.

Na segunda parte saliento alguns aspectos da República. Primeiramente, a novidade política que a República inaugura, qual seja, a idéia fundamental de que tudo e todos têm que assumir uma função social, o que oscila é se estão administrados por um particular ou pelo Estado, mas tudo deve cumprir uma função pública e ao público se dirige. O privado pertence à esfera pública e só pode ser exercido como uma concessão da sociedade civil aos seus cidadãos e às suas instituições.

Para ser mais preciso, o poder político republicano entendido como poder aberto ao público começa em Kant na Paz Perpétua, ao considerar como fórmula transcendental do direito público o princípio segundo o qual todas as ações relativas ao direito de outros homens cuja máxima não é conciliável com a publicidade são injustas. A res publica não apenas no sentido próprio da palavra, mas também no sentido de exposta ao público, exigindo que o poder seja visível: o lugar onde se exerce o poder em toda forma de República é a assembléia dos cidadãos e na praça. Portanto, por público também deve ser entendido aquilo que é manifesto, aberto ao público, feito diante de espectadores, e por 
privado, ao contrário aquilo que se diz ou se faz num restrito círculo de pessoas e, no limite, em segredo.

Essa foi uma profunda transformação da imagem do Estado e das relações reais entre governantes e governados, do nascimento do político público, no qual a esfera pública adquire uma influência institucionalizada sobre o governo através do corpo legislativo e da opinião pública, onde o exercício da política é efetivamente submetido à obrigação democrática da publicidade. Ao público, como o bem comum da sociedade, acrescentourse aquilo que é manifesto e está aberto à observação geral: sair em público é uma ação política, e porque o público é o bem comum e o corpo político, uma região especial de sociabilidade, o público enquanto platéia não deixa de ser também um ator para o desenvolvimento do espetáculo cômico, dramático ou trágico da política.

Assim, numa República o que se contrapõe ao privado é o estatal, e o que se contrapõe ao público é o clandestino. Numa República, uma propriedade privada pode ser desapropriada em nome de uma função pública maior (por exemplo, se quiserem construir estradas, ruas, barragens para hidroelétricas, linhas de transmissão de energia elétrica etc., sobre minha propriedade, irão me desapropriar), ou caso não esteja cumprindo ou colaborando com o desenvolvimento social (por exemplo, desapropriando as terras inativas para fins de reforma agrária), ou caso o produto ou uso dela seja prejudicial ao público (por exemplo, bens obtidos através do narcotráfico, do contrabando, do roubo), assim como o governante pode ser deposto caso não cumpra com seus deveres.

A oposição entre público e privado numa República não ocorre, ou não deveria ocorrer. O que pode ocorrer - mas, não necessariamente ocorrerá - é uma oposição entre o privado e o estatal, onde o privado tenta limitar a ganância estatal sobre o social e seus indivíduos; fundamentalmente é o Estado que precisa ser ransformado numa entidade republicana em contraposição a um Estado absolutista, despótico, colocando-se freios ao seu ânimo absolutista que não permite nem ao menos a propriedade de si mesmo, a primeira de todas as propriedades ${ }^{1}$. É quando os ingleses fazem sua revolução no século

\footnotetext{
1. Aqui, sem dúvida, Locke e seu Segundo Tratado Sobre o Governo é referência obrigatória. Simplificando o que nos diz o autor: ainda que a terra e todas as criaturas sejam para benefício comum de todos os homens, sem embargo, cada homem tem a propriedade de sua própria pessoa. Nada, salvo ele mesmo tem direito sobre ela. Cada um possui não só a posse de sua pessoa, mas também seu trabalho, que constitui a extensão imediata de sua pessoa. O esforço do seu corpo e a obra de suas mãos são também autenticamente seus. Todas as demais propriedades se derivam desta propriedade primogênita original, natural. Sempre que se retira algo
} 
XVII que se inaugura a República moderna: não permitir que o Estado crie ou aumente os impostos sem a concessão da sociedade civil!

Em segundo lugar, saliento um fator decisivo na atualidade: a sociedade, em todos os seus níveis, æe não inviabiliza, dificulta a possibilidade de ação política. Ao invés da ação, a sociedade espera de cada um dos seus membros um certo tipo de comportamento, impondo inúmeras e variadas regras, todas elas tendentes a "normalizar" e normatizar os seus membros, a faze-los comportarem-se, a abolir a ação espontânea ou a reação inusitada.

$\mathrm{O}$ ocidente desenvolveu uma educação para a vida social que prioriza a busca do desejo dos grupos ou dos indivíduos; uma República autêntica precisa de uma educação para valorizar a vontade e a capacidade de renunciar ao desejo ou de reduzi-lo. Um projeto político consistente, reunindo a sociedade, pressupõe que se renuncie às vantagens imediatas, o que requer a austeridade republicana e a compreensão democrática: pensar em justiça não apenas como "temos direito à justiça" mas também como "temos que ser justos".

Por fim, na última parte, esboço parâmetros para a realização de uma ação política que vise uma ética humanitária. Em primeiro lugar, saliento a liberdade, não como um dom natural ou um direito inato (ainda que seja da nossa natureza), mas como uma prática que deve ser aprendida e exercitada, e que só pode ser exercida em conjunto com os demais humanos. Nos textos de Platão, Aristóteles, Kant, Nietzsche ou para citar alguém mais recente, Hannah Arendt, a liberdade não é propriamente uma questão de direito político ou econômico, como é majoritariamente tratada a questão atualmente. É também fruto de uma conduta ética: ser livre é saber limitar suas necessidades dominando-as, submetendo o corpo à soberania do espírito de maneira a não depender de outrem, de acordo com uma consciência ampliada da vida humana em comum.

Logo, a liberdade não é a chamada liberdade do querer ou meramente individual, de só fazer o que se quer e quando se quer, que pode acarretar - como ocorre normalmente em não fazer o que se deve fazer, mas uma liberdade civil e humana: a natureza e os limites do poder que a sociedade legitimamente exerce sobre o indivíduo e o indivíduo sobre si mesmo, pois as benesses da liberdade pertencem também à espécie e não apenas aos

da terra comunal natural e ponha nele seu esforço, esse algo é seu, quando esse bem existe em quantidade suficiente para os demais. Os homens mediante seu trabalho, inventividade e laboriosidade fazem possível o incremento e resolvem com isso os problemas econômicos que os acossam na condição natural. Porém ao mesmo tempo fazem impossível a continuação desse estado de natureza e tornam necessário um estado civil. 
indivíduos particulares, e devem desfrutar com parcimônia, pois quanto mais exercer a liberdade, mais responsabilidades irá assumir. A liberdade é um poder, e como todo poder, é uma relação entre pessoas que se constrói diariamente; como os demais poderes, não fica restrito em receptáculos, não se acumula, não se retém, nem pode ser armazenada e mantida em reserva: só existe na sua efetivação. Se não é efetivada, perde-se; e a história está cheia de exemplos de que nem a maior das riquezas materiais pode sanar essa perda ou impedila, quando não é a própria riqueza a causa da perda liberdade.

Essas colocações se dirigem para uma questão que normalmente se passa à parte, pois se tem a liberdade como um bem em si mesmo ou um direito inalienável de todos, como se fosse uma virtude, quando ela é um exercício e sua existência ou possibilidade pode acarretar em mais trabalho e dedicação à vida entre os homens do que se imagina; é dela que se origina tanto as virtudes humanas como seus vícios. Ora, a liberdade contém também um lado negativo: a positividade que o termo carrega nos discursos políticos e no senso comum, esconde o fato que a possibilidade criativa humana decorrente da liberdade pode ser usada para o "mal" também. E nesse sentido a liberdade precisa ser pensada também como um ônus e não apenas uma benção. Paradoxalmente, a liberdade só se vive junto aos demais, mesmo que seu exercício seja particular, pois sua idéia como ausência de interferência, para ser vivida efetivamente, é necessária a presença do outro e simultaneamente que sejamos capazes de resistir ao seu domínio e sem exercer domínio sobre ele.

O fato é que não se pode mais ignorar a liberdade individual contemporânea, que é rigorosamente liberação; implica uma relação com um fundo de realidade previamente dado de paradigmas e crenças que, ao mesmo tempo, solicita o ato ou lhe resiste: com certeza não é uma natureza adquirida de uma vez por todas, é uma modalidade do fazer. E dessa liberação surge a violência cometida pelos homens, que se sentem autorizados, em nome de interesses próprios, a impor vontades, desejos e ações aos demais.

Naturalmente, não podemos afirmar se há aumento de violência ou se não estamos apenas com uma percepção mais acentuada do fenômeno. $O$ fato relevante é que a violência contemporânea pode adquirir aspectos nefastos, na medida em que há recursos técnicos e tecnológicos com alcances inimagináveis em épocas passadas. Além disso, aumenta-se 
consideravelme nte o número de atitudes consideradas violentas pela civilização ocidental, ocorrendo mais prisões e mais presídios nos dias atuais.

Em segundo lugar, faço distinções entre ética e moral. A moral, de imediato, cria o seu contrário, a imoralidade, que abrange tudo aquilo que não está prescrito por suas regras de conduta, até mesmo atividades que são amorais, ou seja, atividades independentes e que não visam romper ou transgredir a moralidade aceita por determinado grupo. A moral é mais do que prescritiva, ela visa ser proibitiva, punitiva, caracterizando-se por uma negatividade, ou obriga a pessoa aos seus ditames sob pena de ser condenado pelo seu não cumprimento; a ética visa ser prescritiva e caracterizando-se por ser uma positividade, algo afirmativo, mas não tem a obrigatoriedade coercitiva da lei para seguir seus preceitos, ou seja, a ética é um instrumento da liberdade de escolha. A ética implica nos preocuparmos com a humanidade e leva a redefinir os direitos, e mesmo os direitos humanos, modo de pensar as relações políticas e sociais, o fundamento maior da cidadania contemporânea. Por outro lado, o principal objetivo dos moralistas consiste em identificar e denunciar os vários grupos sociais responsáveis pela erosão do tradicional da moralidade pública e puni-los exemplarmente.

Também abordo a questão da civilização ocidental demonstrar não só quanta importância é nesse momento atribuída ao "bom comportamento", mas, acima de tudo, como aumentou a pressão que as pessoas exercem reciprocamente uma sobre as outras para ações civilizadas. Torna-se claro que uma maneira polida, gentil e relativamente atenciosa de corrigir alguém, é um meio muito mais forte de controle social, muito mais eficaz para inculcar hábitos duradouros do que o insulto, a zombaria ou a ameaça de violência: aumenta-se a compulsão de policiar o próprio comportamento. Hoje em dia é mais deselegante e incivilizado ficar criticando e observando o jeito do outro se alimentar, falar, se vestir, crer, votar, se divertir devido aos direitos inalienáveis da diversidade, da tolerância, da não ingerência na autonomia alheia.

Como existe um objetivo comum para a civilização, segue-se que é preciso uma educação para todos, administrada em comum: aquilo que é comum a todos deve também ser apreendido em comum. O conhecimento é um patrimônio humano e deve estar acessível a todos os seus membros igualmente. Portanto, os estudos das diversas disciplinas devem visar às finalidades instrumentais para potencializar a capacidade reflexiva das pessoas, 
pois não se toma lições com cada uma delas por amor à técnica ou ciência, ou apenas com o fito de exercer determinada profissão, mas para fins educativos, emancipatórios, como convém a um jovem livre, para que possa desenvolver com autonomia seu pensamento e sua ação. Ao mesmo tempo, é preciso não imaginar que cada pessoa pertença a si próprio, e sim que todos pertencem à civilização; porque todo indivíduo é membro da humanidade, o que exige uma educação que possibilite deixar a estreiteza de si para obter a largueza da espécie, dela participar e dela retirar melhores frutos.

Infelizmente, até o momento, o problema é a ignorância das pessoas, individual e coletivamente consideradas, no que diz respeito aos muitos fatores dos quais depende a realização dos seus objetivos, e que aumenta gradativamente com a expansão do conhecimento, pois quanto maior é a soma total do saber humano, menor é a parcela que qualquer indivíduo pode absorver. Quanto menos se sabe, menos se age, menos coisa há para se fazer. Conseqüentemente, mais raiva, impotência e ressentimento se acumulam. Faltam modelos conceituais e uma visão global, mediante os quais cada um possa tornar compreensível, no pensamento, aquilo que vivencia diariamente na realidade, à qual as idéias dos seres humanos como indivíduos e como sociedades possam se harmonizar melhor, e possam compreender de que modo um grande número de indivíduos isolados compõe entre si algo maior e diferente de uma coleção de indivíduos isolados; como eles formam uma sociedade e como sucede a essa sociedade poder modificar-se de maneiras específicas, ter uma história que segue um curso não pretendido ou planejado por qualquer dos indivíduos que a compõem.

Como não sabem deixar claro para si mesmos como é possível que cada pessoa isolada seja uma coisa única, diferente de todas as demais; um ser que sente, vivencia e faz o que não é feito por nenhuma outra pessoa; um ser autônomo e, ao mesmo tempo, um ser que existe para outros e entre outros, com os quais compõe a sociedade de estrutura cambiável, findam por não perceber que estão participando politicamente no exercício de sua cidadania cotidiana. Da hora que acordam à hora que dormem, ao tomarem um café no bar ou tomarem uma condução para o trabalho, estão participando do desenvolvimento social e humano.

Enfim, se há luta política a ser travada, essa se dá entre a sabedoria e a ignorância, e não mais entre um bem e um mal arbitrariamente estabelecido pelas moralidades 
particulares. Acabou a época em que teríamos que salvar o mundo das obscuridades das elites ou da exploração dos fortes. Fundamentalmente, o que proponho é que cada um participe o melhor possível do exercício de sua cidadania como forma de atuação política republicana, salvando a si das tentações que acredita existir apenas nos outros. Melhoramos o mundo melhorando principalmente a nós mesmos.

O que motiva filosofar é uma constante tentativa de decifrar o mundo contemporâneo e a criação de antídotos ao problema crucial do risco de um totalitarismo crescente do Estado ou na sociedade, fazendo com que o sentido dos eventos saia dos próprios acontecimentos inusitados e narrados. A única forma de entender os fenômenos contemporâneos que se recusam a se submeter às categorias da tradição filosófica está na lenta reconstituição dos acontecimentos, que possibilita apreender seu sentido "oculto". A compreensão, como algo distinto da informação correta e do conhecimento científico, é um processo complicado que nunca produz resultados inequívocos. É uma atitude sem fim, por meio da qual, em constante mudança e variação, nos ajustamos e nos reconciliamos com a realidade, isto é, tentamos estar à vontade no mundo através do seu debate.

Acredito na capacidade de cada um pensar por conta própria, capacidade essa que incorpora, mas não pode e não deve ser substituída por pensadores clássicos e/ou consolidados, ou por convicções advindas de alguma fé fervorosa, pela opinião pública ou por ideologias. A capacidade de pensar por conta própria não pode ser inibida pela lealdade a autores ou povos e crenças. Se a discussão sobre problemas sociais e políticos transita através de uma incapacidade de refletir para além de paradigmas teóricos dominantes, e se coloca tributária de agendas políticas programáticas das ações partidárias, ou dos atores mais poderosos dos agentes econômicos e sociais, sucumbindo a uma lógica cujos termos e tempo seguem necessidades imediatas de respostas pragmáticas para problemas pontuais do aqui e agora, nunca gerando reflexões de longo prazo, como exige uma reflexão compromissada com um entendimento mais amplo, cabe ao homem livre entrar na discussão e trazer esses pontos à tona.

Por fim, ainda que este trabalho seja o produto de um estudo e reflexão de quatro anos, é como membro comum da platéia e ator coadjuvante que foram colocadas essas observações. Não é apenas um estudo científico de caso, muito menos um grito de 
indignação pelas ocorrências. Se há uma pretensão é a defesa de uma posição política, amparada numa certa filosofia, mas que pelo seu caráter embrionário não é possível ser algo plenamente justificável - se é que alguma coisa o é. A realidade objetiva é uma convenção social, o que torna irrisório o dogma, segundo o qual existe um mundo exterior à consciência, cujas propriedades são independentes de todo indivíduo e até mesmo da humanidade inteira; ao contrário, a realidade física, tanto quanto a realidade social é fundamentalmente uma construção lingüística cultural e social. Uma vez colocadas em palavras e tornadas públicas, as idéias podem ser desviadas de suas intenções, como essas palavras aqui esboçadas, pois que os sentidos não podem ser estabelecidos só pelo autor. 


\section{Parte 1: UM ANIMAL POLÍTICO?}

A estupidez é infinitamente mais fascinante do que a inteligência. A inteligência tem seus limites, a estupidez não.

anônimo 
Das várias definições que o ser humano criou para si, talvez a que mais repercussão causou no Ocidente tenha sido a definição de Aristóteles: “o homem é um animal político". Político aqui tem o sentido de ser participante e originário da Polis, que significa cidade, em grego. Logo, dizer que o ser humano é um ser político é o mesmo que dizer o homem é um habitante de cidade, um ser que participa da vida e das decisões de sua cidade. Não interessa aqui salientar os limites de tal definição que, como toda definição, ao recortar um elemento da realidade parece restringíla e simplificá-la. Mas, recuperar um lado da faceta humana cada vez mais visível através da história, o fato do homem (ou pelo menos parte significativa da humanidade) habitar cidades e instituir costumes, regras, leis, sendo a política $^{2}$ o resultado dessa capacidade instituinte.

Ao ser traduzida para o latim, a expressão grega Zoon politikon foi resignificada, recebendo a tradução de animalis socialis, através de Tomas de Aquino: homo est naturaliter politicus, id est, socialis (o homem é, por natureza, político, isto é, social) ${ }^{3}$. Para Arendt, a idéia de sociedade ou social era estranha ao grego, tendo sido retirada da cultura romana, porque a política na Antigüidade grega indicava uma certa aliança voluntária entre as pessoas para um fim específico. Além disso, para ela, ainda que Aristóteles não ignorasse o fato de que o homem não pode viver fora da companhia de outros homens, ou não considerasse de suma importância o que se chamou posteriormente de sociedade, isso para ele não era uma característica especificamente humana que pudesse distinguir os homens dos demais animais. Formigas, abelhas, cupins, macacos têm sociedades. A companhia natural da espécie humana era vista como uma limitação ou uma decorrência

\footnotetext{
${ }^{2}$. Em sentido estrito política é os negócios da polis, porque esta palavra grega designa a urbe (por oposição ao campo), mas também a civilização (por oposição à natureza selvagem ou à barbárie), e finalmente, e, sobretudo, a cidade, entidade comunitária autônoma, à qual algumas dezenas de milhares de habitantes têm consciência de pertencer reconhecendo nela algo como a sua pátria. A rigor a polis não é a cidade-estado em sua localização física; é a organização da comunidade que resulta do agir e falar em conjunto, e o seu verdadeiro espaço situa-se entre as pessoas que vivem juntas com tal propósito, não importa onde estejam.

3. ARENDT, H. A Condição Humana, p. 32. Interessante notar que Lebrun no texto O Que é o Poder também nos fala algo semelhante. Diz nas páginas 37/38 que é significativo que Santo Tomás não repita Aristóteles: O Homem é um animal político, mas diga: o homem é um animal social. Ora a societas não é a cidade: é um conjunto de atividades que não tem por objetivo o bem comum, e que apenas precisam exercer-se no quadro da paz. É neste ponto remoto que principia a nossa modernidade: quando a comunidade não mais é entendida como congregação de homens que são diretamente encarregados de zelar pelo funcionamento do Todo, mas como uma congregação de homens (societas), a quem seus próprios afazeres ocupam demais para que possam dedicar-se aos interesses do Todo, e que, por isso, devem ser protegidos pela instância política, em vez de participarem dela.
} 
imposta pelas necessidades da vida biológica, mas não uma criação própria, um produto da liberdade e da racionalidade humana como era a política.

Todavia, salienta Arendt, o que diferencia os homens dos demais animais, no pensamento aristotélico, era a sua capacidade de organização política e urbana (e não meramente social), ou seja, para além da vida privada da família, da casa e do clã, da subsistência, do aglomerado de seres da mesma espécie, o homem adquire uma segunda vida, uma vida pública e citadina que escapa daquilo que é meramente útil e necessário à sobrevivência. Portanto, o cidadão pertence a duas ordens de existência, a sua vida entre aquilo que lhe é próprio e particular e a sua vida entre aquilo que é emcomum.

Viver na cidade é mais que uma mera vida social, é viver num local onde se desfaz do tempo natural cíclico ou do ciclo selvagem da vida nômade e agrícola, da vivência em bando, rebanho ou multidão, e se institui uma vida na qual ocorre a ação e o discurso dos seres humanos, que eternizam, através da história, cotidianos diferenciados com ditos e feitos que ficam preservados para a posteridade na memória dos vivos. É importante salientar a distinção entre natureza e cultura porque é necessário apontar para a singularidade do lado simbólico do humano, que reconstrói a natureza de acordo com milhares de variáveis, de acordo com o seu entendimento do mundo, transformado em símbolos, para que possa operar sua racionalidade em comunhão com outros homens através da política e em público. Essa é senão a natureza, a condição humana, que cria uma cultura que determina a relação dos homens com as coisas e consigo próprio.

Para Arendt, o grego inaugura o político propriamente dito, ou seja, o viver numa polis, onde tudo é decidido mediante palavras e persuasão, e não através de força e violência. A instituição do poder político representa que ao invés de forçar alguém mediante violência ou ordem, característicos do lar e da vida em família (ou mesmo da vida selvagem e natural), na qual o chefe da casa imperava com poderes despóticos ${ }^{4}$, se impõe a fala entre iguais, que persuade e convence pelos argumentos, pelo poder que vem da

\footnotetext{
${ }^{4}$. Quantas diferenças com os tempos atuais, onde não mais se pode bater em filhos e esposas, também figuras públicas e sujeitas ao direito: deveres sempre tiveram. Esse tipo de privacidade foi extinta há poucas décadas e em poucos lugares. Não pela força dos governos, mas por um dever de consciência que vem se generalizando pelo ocidente e gerando um processo civilizatório, onde se avista e respeita os direitos mútuos, e leis fortes suficientes para serem razoavelmente respeitadas. Por serem as relações pessoais coisas públicas, ou seja, sujeitas ao aval mútuo e comum, há limites e possibilidades que não se pode mais impor, ou dispor, aos indivíduos, independente da idade, do sexo ou de qualquer outro diferencial que se procure. Em países onde o Estado ainda não é laico, até mesmo células e embriões estão sujeitos a leis e não se pode dispor deles de acordo com a consciência.
} 
autoridade e não pela força que vem do autoritarismo. Somente na cidade, organização fundada não sobre a força bruta, não sobre interesses passageiros, não sobre prescrições dos deuses, é que o homem pode realizar a virtude (capacidade) inscrita em sua essência, um animal que possui a capacidade de falar de maneira sensata e de refletir sobre seus atos.

$\mathrm{Na}$ vida natural impera a força física e a astúcia; na vida urbana impera o poder político e a racionalidade. Nesse sentido, a cidade não seria um mero fenômeno social, histórico ou natural, mas também um produto original da criatividade e da liberdade humana que não apenas se submete ao tempo e ao espaço, ou a meras necessidades biológicas da sobrevivência, mas que impõe aos mesmos sua vontade soberana de autodeterminação. A vida privada e a social seriam uma vida menor, animal, selvagem, na qual se está "privado" da plena humanidade, que só pode ser encontrada verdadeiramente apenas na sua capacidade pública, ou seja, na vida política e civilizada. Lembremos que o verbo privar significa domar, domesticar, extrair do domínio selvagem e transportar para o espaço familiar da casa (privar da liberdade!). "A vida privada deve ser murada” diziam os romanos.

O homem é um inaugurador de processos, fabricante do destino e das coisas, e portador da liberdade política, ou seja, a capacidade de criar organizações de relações humanas, aonde o sujeito escapa da trivialidade e transcende a vida privada e assume uma função pública, como decorrência da coexistência humana. Um nascimento traz um novo indivíduo ao mundo, obrigando-o através de palavras e atos a se inserir no mundo da polis, que não nos é imposto pela necessidade, mas pela criatividade humana de fabricação: a cada novo nascimento surge um novo começo com mudanças inerentes; o recém chegado tem a capacidade de iniciar algo inédito, pois dotado da potencialidade da ação engendradora.

Ainda que os gregos não tenham sido os primeiros a ter cidades, e possamos debater se teriam sido realmente os primeiros a instituir o poder político, sem dúvida foram os primeiros a refletir sobre esses fenômenos como um problema de instituição humana, e não como mero fenômeno divino ou natural: a política inaugura a laicização da vida pública e se constitui num terreno ilusório, imagético, discursivo, no qual prevalecem as imagens mais que as verdades. E mais, de certo modo influenciam toda reflexão sobre urbanidade e vida política posterior até os dias de hoje, a começar por boa parte da terminologia que se 
utiliza para debater a política. Ainda que possamos enumerar profundas transformações históricas no decorrer dos séculos desde a Grécia antiga até os dias atuais, a urbanidade, a civilização, enfim, a vida em cidade e o poder político continuam a ser eventos que obrigam a refletir sobre a vida humana e traz desde o seu nascedouro algumas questões que, apesar dos milênios que nos separam das primeiras cidades, não conseguem ser satisfatoriamente realizadas e refletidas.

Em primeiro lugar há o problema ambiental agravado na modernidade pelo crescimento populacional e pela capacidade tecnológica de extração de matérias primas para produção de bens materiais. Instituir uma cidade sempre significou, antes de qualquer coisa, transformar a natureza ao redor para atender as necessidades urbanas, ou seja, retirar o homem da vida "selvagem", seja das intempéries do clima e da natureza, seja da violência dos animais ou de outros homens. É preciso recortar montanhas para aplanar o terreno para as construções de casas, palácios, templos, fortalezas, muralhas, estradas etc., ou mesmo para retirar o material para essas construções. Além disso, é necessário cultivar os campos para alimentar esses habitantes concentrados num pequeno espaço; é preciso caçar os animais que estragam as plantações ou caçam os animais domésticos, mudar cursos de rios para armazenar água ou evitar enchentes que destroem cidades e campos, ou ainda irrigar plantações.

Em segundo lugar há o problema organizacional. Instituir uma cidade com poder político significa dividir tarefas, compartilhar deveres e obrigações, conciliar esforços, e dedicar parte do tempo particular as necessidades da vida em comum. Isso pressupõe especialização de tarefas e funções, a percepção da responsabilidade individual e coletiva para o bem comum, a coadunação dos homens e seus trabalhos, uma consciência cívica e ética. Organização entendida não só como algo político, mas também como algo burocrático, administrativo.

Em terceiro lugar há o problema educacional. Enquanto a vida nômade e agrícola é satisfeita com uma aprendizagem iletrada, que passa de pais para filhos conhecimentos práticos, a vida urbana exige conhecimentos técnicos e científicos, letrado e teórico, não apenas para fazer as anotações necessárias à administração estatal ou mesmo privada, mas também para formar profissionais diversos com competências diferenciadas, para realizar planejamentos, além de pessoas que saibam falar e debater as questões públicas para que se 
possa, senão participar, ao menos escolher quem irá exercer a representação política, na medida em que, cada vez mais, parece inacessível a todos exercer muitas das funções públicas. A instituição da cidade traz em seu bojo a criação das escolas e da cultura letrada. Povos civilizados (que em última análise significa habitantes da cidade) são dotados de algum tipo de escrita, o que ocorre até mesmo em cidades ou Estados despóticos.

Em quarto lugar há o problema da convivência social. A cidade impõe a convivência e a tolerância entre pessoas diferenciadas repartindo e coabitando espaços, tornando público e comum o que antes fazia parte do privado, do familiar, do clã ou do grupo. Criar espaços para o estrangeiro, para o outro, para a troca, para o encontro social, para o movimento das pessoas, e ao mesmo tempo preservar a individualidade e a privacidade, eis a equação a ser resolvida. Como satisfazer a todos sem ferir os interesses de alguém? Como transformar uma sociedade numa comunidade política, para que as pessoas sejam mais que sócios e se tornem cidadãos?

Naturalmente, com o passar dos séculos problemas foram sendo acrescentados, não apenas por questões econômicas e sociais, mas até mesmo por questões e descobertas epistêmicas, que vêm acarretando revoluções científicas e técnicas, e profundas transformações materiais e de comunicação, assim como a própria compreensão do ser humano. As questões da higiene, do lixo, da qualidade do ar, da água, da saúde, da vida e de lazer, de abastecimento, ou ecológico, urbanístico, arquitetônico, artístico etc., foram sendo introduzidos conforme se ampliou o conhecimento técnico-científico do homem e modificou sua produção material, conseguindo cada vez mais ampliar a capacidade de ter mais que o necessário para a sua mera sobrevivência, e artificializando mais sua vida e sua convivência. A cidade que num primeiro momento foi apenas um centro políticoadministrativo ou defensivo de uma determinada população tornourse um centro comercial, cultural e, mais recentemente, na modernidade, um centro produtivo, educativo, industrial e financeiro, e que abriga um contingente populacional significativo, ultrapassando nas últimas décadas o contingente populacional do campo.

Os fenômenos inimagináveis ao grego antigo ou mesmo para muitos pensadores dos tempos modernos que ocorreram e que ocorrem, acarretaram modificações nas relações sociais e políticas que não mais se encaixam em noções e pensamentos herdados dessa Antigüidade e Modernidade. O mais visível é a tecnoburocracia substituindo a política nas 
decisões urbanas, a fragmentação cada vez maior das atividades e das competências, de tal modo que temos hoje dificuldade de identificar e de entender os problemas políticos, ou distingui-los dos sociais, ou ainda ousar propor soluções. Assim como a cidade e a urbanização se tornaram um problema técnico ou científico, estando suas decisões e planejamento no poder de especialistas, a política também se tornou uma profissão e quer se tornar coisa de especialistas, procurando realizar mais uma engenharia social do que a efetivação da participação dos cidadãos no espaço público.

Do ponto de vista político, ou melhor, da participação política, que é a temática deste trabalho, enquanto da Antiguiidade até a Idade Média estudavam as diferentes formas de governo por sua capacidade de ajudar o homem a alcançar uma meta moral na sociedade, a justiça e uma vida digna, os escritores modernos inauguram uma meta menos ambiciosa: evitam manifestar ideais, conceitos como vida digna e enfatizam os meios, a eficiência do sistema político, sua capacidade de promover a paz e a abertura de horizontes. Para os modernos, torna-se quase uma obsessão a busca de políticos profissionais que sejam guiados por sua experiência na arte do possível. Os pensadores "democráticos" acrescentam que é desejável que os mesmos sejam controlados periodicamente por meio de eleições: dispositivo que permite ao povo fazer uma escolha entre grupos de especialistas em pleito.

O fenômeno contemporâneo da coexistência entre eleições e democracia ${ }^{5}$, como um fato corriqueiro e natural, não foi sempre assim. O princípio eletivo é essencialmente aristocrático, pressupondo uma desigualdade intrínseca entre os homens, ou seja, que havendo pessoas melhores e piores para serem governantes ou legisladores, e sendo necessário que se escolha, se eleja um comandante para os comandados. Nega o princípio elementar da democracia, da igualdade entre os homens, que todos são aptos para governar, legislar e julgar seus concidadãos e ser por eles governados, legislados e julgados. Nos primórdios da democracia escolhiam-se legisladores e juízes por sorteio, e as decisões políticas eram tomadas em assembléias, abertas a todos os cidadãos, onde propostas (não homens!) eram escolhidas e eleitas como as melhores ou piores, de acordo com a conjugação do momento, que incluía variáveis, como a força da persuasão do discurso.

\footnotetext{
5. Recorro nesse como nos próximos quatro parágrafos aos textos de AVRITZER - A moralidade da democracia, FINLEY - Democracia antiga e moderna, RIBEIRO - A democracia, e Dahl - Sobre a Democracia.
} 
O povo não só era elegível para cargos públicos e possuía o direito de eleger administradores, mas também era seu direito decidir todos os assuntos políticos e o direito de julgar, constituindo-se como tribunal, todos os casos importantes civis e criminais, públicos e privados. A concentração de autoridade na Assembléia, a fragmentação e o rodízio dos cargos administrativos, a escolha por sorteio, a ausência de uma burocracia remunerada, as cortes com júri popular serviram para evitar a criação da máquina partidária e de uma elite política institucio nalizada que se auto-perpetuasse no poder. Sem dúvida que surgiram líderes políticos, homens como Péricles formavam uma elite política em Atenas. Porém, era necessário desempenho público na Assembléia: o acesso a ela era aberto, mas para permanecer como me mbro atuante era preciso manter o desempenho.

O que é mais importante salientar é que os atenienses caminhavam sozinhos. Naturalmente, tinham assistentes, técnicos, escravos, e também políticos que realizavam alianças e executavam missões. Não obstante, esses laços eram fundamentalmente pessoais, com freqüência instáveis, úteis para a execução de uma medida ou mesmo de um conjunto de medidas, mas sem a característica do apoio, aquele efeito de sustentação ou de proteção representado pela burocracia ou por um partido político. O ponto crítico é que não havia governo no sentido contemporâneo. Havia postos, cargos, mas nenhum deles tinha qualquer posição na Assembléia. Um homem era líder exclusivamente em função de seu status pessoal, e literalmente não-oficial, na própria Assembléia, e muitas vezes apenas naquela Assembléia. Portanto, o mais estranho para nós, contemporâneos, é que na democracia ateniense não havia cargos fixos: havia antes encargos. Uma assembléia tomava uma decisão; era preciso aplica-la; então se incumbia disso um grupo de pessoas. Mas essas não eram eleitas, e sim sorteadas. Isso porque a eleição cria distinções. Se escolhermos pelo voto quem vai ocupar um cargo permanente ou temporário, nossa escolha se pauta pela qualidade. Elegemos aquele que achamos melhor, mas o lugar do melhor é a na aristocracia. A democracia é um regime de iguais, e, portanto, todos podem exercer qualquer função.

Com certeza, nem a Assembléia soberana, com seu direito ilimitado de participação, nem os júris populares, nem a escolha de administradores por sorteio, nem o ostracismo poderiam ter evitado o caos social e político ou a tirania se não houvesse simultaneamente a tudo isso, um considerável autocontrole entre uma representativa parte do corpo de 
cidadãos para manter seu comportamento dentro dos limites. Havia uma educação, uma formação para o desenvolvimento das virtudes morais e do sentido de responsabilidade cívica, de identificação madura com a comunidade, suas tradições e valores. Um jovem se educava comparecendo à Assembléia; ele aprendia não geometria ou geografia, as questões técnicas ou científicas, mas as questões políticas, as escolhas, os debates e aprendia a avaliar os homens que se apresentavam como políticos atuantes, como líderes.

Entretanto, uma sociedade verdadeiramente política, na qual a discussão e o debate são técnicas fundamentais, é uma sociedade cheia de riscos e crises. Há espaço para a demagogia, o populismo ou coisas piores. De tempos em tempos, é inevitável que o debate passe da tática para os princípios básicos, que haja um desafio não só às políticas imediatas daqueles que detêm o poder governamental, mas também aos princípios a eles subjacentes; enfim, que haja uma contestação radical. Isso não é só inevitável, sob inúmeros aspectos é também desejável para uma democracia. Igualmente inevitável é o fato de que aqueles grupos de interesses que preferem o status quo ofereçam resistência à contestação, por diversos meios, dentre os quais o apelo a valores, mitos e crenças tradicionais, profundamente arraigados, através da manipulação do medo e da ignorância.

Essa instabilidade estrutural da democracia gerou na Antigüidade uma repulsa, pelo menos entre os pensadores da política, a esse regime político, que se iniciou em Platão e foi até o Iluminismo. Raros foram os filósofos que teceram elogios à democracia, o que só começou a ocorrer de fato no século XX, quando, então, tornourse uma unanimidade, fenômeno nunca visto antes na história do pensamento político. Hoje, mesmo aqueles que se colocam contra as democracias institucionalizadas, falam em nome de democracias supostamente idealizadas como superiores.

Mas, o século XX deixou de lado dois elementos centrais para a teoria democrática dos séculos XVIII e XIX, assim como um fundamental da democracia antiga: a noção de soberania absoluta do povo e a noção de que a democracia é uma forma de autodeterminação moral, assim como a possibilidade de haver participação política direta dos cidadãos como na Antigüidade, necessitando-se, assim, da representação política. Naturalmente, se mantém a identificação da forma majoritária de governo como aquela que aglomera o maior número de interesses sociais como sendo uma medida substantiva do bem comum, mas essa democracia se consolidou como forma de governo aceitando no seu 
interior um estreitamento ao mínimo (por vezes e na maioria delas, basta que paguem os impostos!) da participação dos cidadãos, pois os interesses econômicos e privados lhe são prioritários, concomitante ao estreitamento da participação nas decisões políticas. Há a implosão do mito da unidade da vontade geral, substituída por uma pluralidade de vontades que podem, no máximo, chegar a um acordo entre si sobre procedimentos comuns para resolução de divergências.

Além disso, uma das características básicas da política ocidental moderna e da democracia contemporânea tem sido a exclusão tanto do mundo afetivo como ético da discussão política propriamente dita. Concebida em termos racionais, seus conceitos básicos - liberdade, igualdade, alternância no poder, respeito às escolhas do outro constituem um esforço nem sempre fácil de praticar, e facilmente se invade a privacidade ou até mesmo a intimidade de pessoas em nome de bens estipulados como públicos por alguma autoridade instituinte. Questões éticas se tornam coisas de ordem privada: tentar aplicar mecanicamente valores éticos como honestidade, lealdade, fidelidade, possibilita incorrer antes em ruína do que instituir o certo. Que isso possa parecer imoral, o fato é que é amoral, e assim é que se tem permitido a convivência de valores diferentes numa mesma sociedade: o relaxamento da moral na política parece ser parte da condição da liberdade moderna.

A superação do empecilho para um desenvolvimento democrático devido à passionalidade das massas, vem ocorrendo através da limitação da participação na política, restringindo-a ao voto, e todas as demais atribuições governamentais ou estatais passam a fazer parte dos encargos de uma elite e de uma burocracia. Concorre para isso o aumento da complexidade das sociedades modernas, que exige a transferência de meios de administração e produção para o controle de funcionários especializados, impossibilitando à maioria tomar decisões sobre problemas que são colocados como intrinsecamente técnicos e especializados.

Além disso, ainda que para a ocorrência de uma democracia seja necessário que se constitua um arranjo institucional capaz de permitir que os indivíduos alcancem um acordo acerca do significado do bem comum, e que se suponha que cada um pode, através da argumentação racional, entender ou ser convencido acerca de uma concepção unificada do bem comum, a história mostra que mesmo as questões que podem se constituir em objeto 
de consenso entre a população, por exemplo, a necessidade de um sistema de saúde público, pode envolver discordâncias que nem sempre são passíveis de resolução racional.

Para a atualidade não existe mais o povo, o homem, mas homens e mulheres, culturas e interesses distintos, contrastantes e não poucas vezes conflitartes. A introdução do axioma do auto-interesse, cujo pressuposto é que cada indivíduo dá preferência à sua própria felicidade quando essa entra em conflito com a felicidade dos demais indivíduos, gera a legitimidade da pluralidade de interesses contemporâneos. Tal pluralidade implica na existência de uma diversidade de valores, que em boa parte transcendem a mera racionalidade ou mesmo a razoabilidade.

A liberdade das pessoas de usufruir seu próprio esforço, de realizar apenas as coisas que lhe interessa, que, sem dúvida, representa uma grande conquista da modernidade teve um preço: tornou uma ficção o princípio acerca do indivíduo racional. Mesmo nos eventos mais cotidianos somos mais indivíduos-consumidores do que cidadãos. Não temos preferências definidas e nossas atitudes em relação a elas não se assemelham a nada de racional: somos susceptíveis à influência da publicidade, da propaganda (quando não da mera fofoca!) e outros métodos de persuasão, que fazem parecer que nossas preferências são impostas pelos produtores ou mesmo pelo produto. Acrescentemos ainda a existência de uma propensão dos indivíduos a se interessarem ainda menos pelas questões políticas do que pelas questões econômicas, e vemos a propensão de ceder moralmente e civicamente a impulsos e preconceitos passionais ou extra-racionais, distanciando os indivíduos de comportamentos racionais na esfera política.

A partir do século XX imensas máquinas partidárias sobrepujaram a voz dos cidadãos em todo lugar, mesmo em países onde a liberdade de discurso e associação estava intacta. A transformação do governo em administração, ou das Repúblicas em burocracias, e o desastroso encolhimento da esfera pública que as acompanha faz com que a liberdade, ou seja, o poder de agir, encolha todos os dias: parece que temos que nos adequar ao sistema operacional de guichês burocráticos. E, como a grande maioria não consegue raciocinar em termos de interesses de longo prazo, quer dizer, o interesse de um mundo que sobrevive a seus habitantes, a si próprio, e poucos são os educados para essa percepção, esperar de pessoas que não têm a menor noção acerca do que é uma res publica, coisa pública - aquilo que é de todos e de ninguém - que se comportem de maneira não-violenta 
e discutam racionalmente em questões de interesse público, não parece realista nem razoável. A crescente preocupação consigo mesmo tem tornado mais desejável delegar funções políticas e públicas aos organismos estatais e governamentais, sendo preferível pagar alguém para exercer os encargos públicos, a largar os afazeres pessoais para exercer atividades comuns. E, no entanto, apesar dessa crescente aspiração ao privado, ao particular, ao íntimo, ocorre uma diminuição da privacidade e da intimidade, com crescentes controles sobre a população, vigiada por câmaras, senhas de acesso, compra de bens etc.

O público parece ter se tornado uma platéia que só pode tomar decisões sobre sua vida privada, e o privado é paulatinamente dominado pelo estatal, enquanto o público é vigiado e controlado ou manipulado pelo poder político. Cada vez mais a esfera privada fica restrita a uma mera intimidade ${ }^{6}$ interior. A esfera da política, que era entendida como o exercício da cidadania entre iguais, hoje é percebida como uma atuação profissional que complementa as demais atividades urbanas e tem uma função social e/ou assistencialista. A atividade política está restrita à obediência de cumprir leis e pagar os impostos, ou, em cada vez mais lugares do mundo, depositar votos na urna. Assim, os problemas sociais e humanitários ficaram relegados a uma repartição estatal, cujos méritos ou deméritos são atribuídos aos governantes. A fama dos feitos e dos ditos dos homens na Assembléia ou na praça da cidade, que dava dignidade à política em Atenas ou Roma, é, em sua grande maioria, desde a Modernidade, efêmera ${ }^{7}$, e $\operatorname{logo}$ cai no esquecimento do aparecimento súbito de alguma nova moda, designer, ou palavra de ordem, que aquecem os desejos, mesmo que não consigam satisfazer as necessidades elementares.

E o que distinguia as individualidades e eternizava os homens, os atos e os dizeres que modificam o destino das cidades e das civilizações, assim como dos indivíduos, parece agora estar restrita a uma escolha de produtos consumíveis e perecíveis, tornando a todos cidadãos-consumidores, meros mortais que só podem escolher entre diversos produtos e marcas que estão expostos numa prateleira urbana, incluindo nessas prateleiras os partidos políticos contemporâneos. Ainda que, verdade seja dita, hoje, qualquer um, em qualquer

\footnotetext{
${ }^{6}$. Sem dúvida, aqui a referência é o livro O Declínio do Homem Público: as tiranias da intimidade de Richard Sennett, assim como A Sociedade dos Indivíduos de Norbert Elias.

7. As exceções ficam por conta de homens excepcionais que conjugaram multidões atrás de seus sonhos como, por exemplo, Napoleão ou Hitler.
} 
lugar do mundo, pode atingir seus 15 minutos de fama e falar para todos suas idéias políticas. Outra coisa é se será ouvido, e se ouvido, entendido: as pessoas estão muito ocupadas em suas pequenas grandes coisas.

Talvez, um caminho interessante para abordar o fenômeno da política seja a criação de novos termos, pois as categorias do pensamento político criadas na Antigüidade ou mesmo na modernidade, como por exemplo, representação política, soberania, democracia, nação, nacionalidade, sociedade, contrato social e que são utilizadas até o momento, podem não comportar mais re-significações, e que de tantos vícios e estereótipos que carregam, mais atrapalham do que ajudam a entender o fenômeno humano e a sua relação consigo mesmo, pois é disso, em última análise, que trata a política. Como sugere Hannah Arendt na Origem do Totalitarismo: há fenômenos humanos contemporâneos que não cabem nas categorias do passado, e isso obriga a ser mais narrador ${ }^{8}$ dos eventos, do que juiz dos mesmos.

Outra possibilidade razoável é recuperar significados e sentidos camuflados por visões estreitas, parciais, dúbias, que escondem a política do fenômeno político, ou que omite as responsabilidades parciais de todos na vida comum. Porém, talvez seja melhor tentar sair da

\footnotetext{
${ }^{8}$. A memória é o grande remédio aos males atuais, a única maneira da ação permanecer no pensamento dos homens e não serem esquecidas, e ampliar o nosso entendimento. Na obra A Vida do Espírito Hannah Arendt deixa claro a impossibilidade de se obter um ponto arquimediano de categorias fixas de pensamento de onde se poderia refletir sobre o mundo como fizeram os grandes metafísicos do passado. Isso obriga o filósofo a escapar da tentativa de estabelecer absolutos num mundo submetido ao contingencial, buscando antes que as verdades absolutas, os juízos avaliativos para as ocorrências inusitadas. O papel da filosofia é antes de tudo o de reter informações, aproximando-se mais do historiador ou do poeta do que do físico: penetrar nos interstícios dos acontecimentos descritos e refletidos, a procura de despertar pensamentos livres, deixando sempre aberto a novas aproximações. Cada nova geração tem a obrigação de recontar o passado, inclusive como forma de não reproduzi-lo nos seus aspectos nefastos e como contribuição para as gerações futuras, pelo menos para não incorrere $m$ no mesmo erro. O pensamento é um ato ou um processo sem fim, que não tem um início determinado (ainda que sempre tentemos data-lo), nem um fim previsível; talvez seja o exemplo maior de nossa condição humana de liberdade. Percebe-se uma tentativa de reconciliar o filósofo com o político algo que segundo Arendt se distanciou desde Platão. A imparcialidade dos julgamentos filosóficos não vem de um distanciamento através de uma localização externa ao evento, onde a partir de um princípio teórico se obtém um ponto seguro de análise que legitima ou repudia comportamentos, mas da tentativa de reconstruir a experiência passada no intuito de encontrar a sua significação, ou que pelo menos não a deixe cair no esquecimento. De qualquer modo, parece não ser uma atividade isolada, de um pensador fechado num claustro e distante do mundo da ação, mas decorrente desse contato entre homens, na "sujeira" do dia a dia; a filosofia deve provocar a troca de experiências e servir fundamentalmente à capacidade humana de fazer distinções. Há uma aproximação do filósofo com o artista e com o poeta, distanciando-o do cientista, fazendo dele mais do que um senhor de conceitos e técnicas, um narrador inspirado que relata ocorrências. Sem ser o senhor da verdade ou da ilustração, ele pode apenas deixar saliente os fenômenos para que todos possam por conta e risco realizar suas conclusões e reflexões, que de forma alguma seria um patrimônio exclusivo da filosofia ou do filósofo. Há um gesto de liberdade no filosofar arendtiano, pois a narração não deixa de ser uma forma de participação nos eventos políticos, já que o falar é também um agir.
} 
linguagem técnica e recuperar a linguagem ordinária como veículo para o debate político, afinal de contas, é na opinião pública que a política se realiza. Tudo isso com um agravante para a contemporaneidade: a relação humana não se dá apenas dentro de redutos distintos do planeta, nem seus efeitos abrangem tão somente regiões específicas e delimitadas. Para além de uma cidadania municipal, há a estadual, a federal, a nacional e a global: cidadãos de si, do município, do estado e do país, mas também cidadãos do mundo.

Entretanto, diferentemente de todas as épocas anteriores, nunca desfrutamos de tanta liberdade, de tantas possibilidades e instrumentos para instituir uma posição política, de tanta independência para traçar o próprio rumo ou interferir na opinião pública. Mas, poucos ousam exercer essa liberdade. Grande parte tem preguiça de buscar sua independência, e quase todos sabem reclamar do que está acontecendo na política ou com os "políticos", mas, quase ninguém sabe o que fazer ou sugerir. Verdade que muitos querem o poder político, porém, tudo que atingem, de fato, é a força do Estado.

Mais do que o cidadão, a modernidade parece inaugurar o indivíduo com direitos naturais? - aqueles que temos só porque nascemos, sem depender da vontade de ninguém. A instituição dos direitos, principalmente pós revolução inglesa, constituiu a idéia de que o crucial para exercer a cidadania é limitar o poder dos governantes e dos poderosos por títulos ou fortuna. Não vamos entrar no pormenor que a luta e as conquistas de direitos não expressam exatamente a atitude de quem é um cidadão, mas de algum súdito que quer reduzir ao máximo sua sujeição, sua condição de súdito. O fato é que tal cultura política tem transformado a política num processo de paulatinamente ir tirando privilégios dos "poderosos" e dando-lhe deveres, e, simultaneamente, retirando obrigações dos súditos e dando-lhes direitos. Falta o principal para sair da esfera do social e adentrar na esfera política propriamente dita, perceber a responsabilidade mútua pelo destino político da cidade.

\section{1- Uma Genealogia da Política}

Ao se abordar o fenômeno político, envolve-se em duas questões caras à Filosofia, esbarra-se em posições metafísicas antigas a respeito do Homem, mas não velhas: a liberdade e a racionalidade. Naturalmente, o fenômeno político, como conhecemos e 
desenvolvemos através da história, parte de um princípio básico instituído pelos gregos: o homem é livre e racional. Isso significa que, para além das contingências da fortuna ou dos desejos dos deuses e da natureza, são os homens os responsáveis pelo seu destino enquanto "raça", cidade, povo; são livres para atingir a sua glória e a sua eternidade ou a sua desgraça e o seu fim. Não estão presos a um destino natural, porque qualquer homem pode alterar a natureza para seu conforto e satisfação. Sendo assim, é a única criatura a desfrutar da liberdade, que significa a possibilidade de instituir para si mesmo seus costumes e a forma de convivência entre os homens.

Simultaneamente a essa liberdade, há o fato de que o homem possui a racionalidade, que transmite as sabedorias e as artes humanas entre as gerações e entre contemporâneos, produzindo maiores e melhores conhecimentos, permitindo o convívio entre os homens de forma falada, entre pessoas que, através da discussão dos problemas, podem controlar a si próprio e aos demais, assim como ser controlado por todos, sem ser pela violência, força ou mero adestramento, voluntariamente. A liberdade e a racionalidade é que permitem aos homens se auto-instituir a vida na polis, realizar o político, instituir o público, criar leis às quais os homens podem se adequar e transformar quase que cotidianamente. Logo, um dos elementos que faz do homem um ser diferente dos demais animais é a fala, que nivela o mundo num entendimento comum a todos, que permite o convívio social entre os homens de tal modo a potencializar a todos em torno de objetivos comuns e desejos compartilhados, e trocar bens e idéias para a múltipla satisfação.

Se a liberdade é decorrência da racionalidade ou o inverso é de todo irrelevante para se refletir o problema político, ainda que possa ser uma questão riquíssima para metafísicas respeitáveis. De fato, não se avista uma separadamente da outra, e pode-se perfeitamente definir o ser humano como racional, como um ser livre, como político, como um ser social, como um ser cultural, e se percebe que todas essas definições, sob um certo ângulo, podem ser vistas como uma descrição das inúmeras facetas de um único e mesmo fenômeno relativo à vida humana.

É importante salientar que as discussões e/ou reflexões sobre política fazem parte do mundo ocidental desde os gregos antigos e podemos afirmar que são permanentes, enquanto houver necessidade da vida em conjunto através de grandes conglomerados humanos que transcendem a vida familiar ou do clã e da tribo. A política nasce ou é 
inventada quando o poder público, por meio da invenção do direito e da lei (a instituição de tribunais) e da criação de instituições públicas de deliberação e decisão (as assembléias), foi separado das três autoridades tradicionais: a do poder privado ou econômico do chefe de família, a do chefe militar e a do chefe religioso (figuras que nos impérios antigos estavam unificadas numa chefia única); a política aparece quando a esfera privada da economia, a esfera da guerra e a esfera do sagrado ou do saber são separadas e o poder político é desincorporado, isto é, deixa de identificar-se o corpo místico do governante como representante humano de poderes divinos transcendentes.

Logo, a política é um processo de laicização da sociedade mística de antes, um fenômeno humano recente: as formas que conhecemos de autoconsciência, a imagem que fazemos do homem, tiveram uma emergência tardia na história da humanidade, começando lentamente e por um breve período se limitando a pequenos círculos da sociedade antiga, para só muito depois, no chamado Renascimento ${ }^{9}$, afetar as sociedades ocidentais enquanto um todo, ainda que diferentemente em cada época e lugar. A noção de uma natureza, mesmo que recheada de inclinações e temperamentos, elástica o bastante para permitir a ação educacional, e de que a articulação dos hábitos e costumes educados é essencial para o bom desempenho político são recorrentes desde os gregos.

Nessa perspectiva, é necessário fazer uma distinção entre política e dominação. Há política quando se renuncia ao uso da força para impor as próprias idéias, e se admite a divergência de idéias ou ideais. Há política quando temos um espaço para tolerar quem não compartilha nossa fé religiosa, quando há um processo de laicização da vida social. Naturalmente, a laicização da política - com seus três traços principais, exclusão da religião como tutora das leis, redução da moral e aceitação da legitimidade do outro lado na vida pública - é mais uma teoria do que uma prática, porque se desenvolve a crença de que não vale a pena participar da coisa pública atingindo-se valores mais altos, os éticos, superando as moralidades pessoais ou de grupos, superando a intolerância tão comum às morais particulares e grupais. Enquanto dominação é o uso da força e da violência para impor regras sociais numa comunidade subjugada por um governante.

Ou seja, para chegar à vida política, é necessário superar o imediatismo dos interesses particulares, dominar as paixões, a ganância, e até mesmo as necessidades, e fazer

\footnotetext{
${ }^{9}$. No caso, foi fundamental a leitura da obra de Skinner, As Fundações do Pensamento Político Moderno.
} 
prevalecer uma razão bem intencionada, uma certa abnegação, assim como o raciocínio de longo prazo. Não que isso sempre ocorra ou possa assim sempre ocorrer, mas há esse ideal como horizonte quando se tenta instituir a vida política. Não há propriamente uma dominação política: se há domínio é porque a política foi banida, pois a mesma é um ato de liberdade e uma exposição de essências pessoais, enquanto a dominação é sempre uma imposição de gestos e aparências para satisfazer o dominante.

Naturalmente, o Estado surgiu antes dos gregos, mas sem eles, não estaríamos discutindo isso que hoje temos e chamamos de Estado, uma forma de organizar as pessoas de modo que os interesses possam ser tratados publicamente na praça, negociados entre pessoas que são iguais, expondo e trocando interesses em público ${ }^{10}$. O Estado se construiu dentro de crenças arraigadas, muitas de origem religiosa, mas tem se encaminhado para uma laicização completa. Seu entendimento caminha para ser tão somente o instrumento de execução das leis humanas. Nesse contexto, os Estados anteriores ao mundo grego (e muitos que existem ainda hoje) são Estados sem vida política de fato (quanto menos de direito) ou pré-políticos, despóticos. A vida política, ou seja, a atividade pública como um exercício da autonomia dos indivíduos com relação aos outros e às instituições com as quais está convivendo (e não submetido), dá um outro caráter à convivência dos homens, substituindo o medo e o temor entre as pessoas do Estado despótico, pela confiança e o compartilhamento da vida comum tida como igualitária. Na Política está contida a afirmação da liberdade do ato espontâneo das pessoas contra a sujeição a imperativos estrangeiros, externos, afirmando o homem como um ser livre, quando de posse de sua potência de pensar, falar e agir, e pode criar o novo e o inusitado, frise-se, concepção bastante recente na história.

Há aqui uma proposta de classificação entre formas de Estado e formas de governo ou regimes políticos, distinguindo a vida política do puro exercício de dominação que se avista nas teocracias, nos ditos Estados e governos orientais, onde se caracterizam pelo uso da força e da violência, ou de punições (reais ou imaginárias) para a organização humana, ou ainda nos totalitarismos iniciados no século passado, mas ainda hoje existentes como o nazismo, fascismo, comunismo, stalinismo, etc.; nada disso deve ser entendido como

\footnotetext{
10. Vernant no seu "As Origens do Pensamento Grego" nos alerta que o advento da Política na Grécia se dá com o avanço da palavra (Logos) sobre a força, o que, sem dúvida é compartilhado por Arendt na sua obra $A$ Condição Humana.
} 
posições políticas, mas como posições que não compartilham qualquer tipo de vida política. Não há propriamente uma vida social, ou comunitária, ou política nessa forma de dominação; não há vida pública ou privada, apenas aglomerações humanas submetidas através do temor a um dominante tido como sobre-humano, que se alimenta e sobrevive graças à ignorância generalizada dessas populações, alimentando os mitos e os medos, e criando uma percepção do mundo e de si como instrumentos serviçais de vontades superiores. Não seria uma mera alienação política como se avista nas culturas ocidentais pós-renascentistas, onde se escohe a privacidade do lar e dos negócios particulares, ao invés da vida pública e dos negócios políticos, mas, a não percepção de possibilidade de escolhas ou mesmo da existência da liberdade. Sem que se tenha a noção de liberdade não se pode atingir a noção do político e de vida pública, e as pessoas acabam se submetendo à crença de um determinismo que impossibilita as escolhas humanas e que cria destinos imutáveis aos indivíduos, seja esse determinismo estabelecido por deuses, pela natureza, pela história ou pela violência do Estado.

A política, portanto, aparece com a idéia de formação cultural, induz ao processo de educação (a Paidéia grega ${ }^{11}$ ), e foi algo que tanto gregos quanto romanos ${ }^{12}$ realizaram: educaram suas crianças, até mesmo seus escravos, cientes da necessidade da educabilidade de sua população para sua defesa e permanência. Aliás, verificamos que o surgimento de instâncias democráticas e republicanas como a Assembléia, o Senado, o Parlamento acarretam a necessidade educativa da população para sua participação emancipatória, assim como para a consciência de sua responsabilidade. Todas as civilizações que tiveram arroubos democráticos e/ou republicanos se viram forçadas a educar a sua população, começando por Atenas, depois Roma e mais modernamente, a Inglaterra no século XVI ${ }^{13}$ : o primeiro país a ter um parlamento moderno, será o primeiro a instituir escolas públicas (que não eram estatais ainda que controladas por ele), por sinal, título de origem inglesa - public school $^{14}$ - que depois se espalhou pelo resto do mundo ocidental, fortemente influenciado

\footnotetext{
11. A referência, no caso, é a Paidéia: a formação do homem grego de Jaeger.

12. História da Vida Privada, de Ariès e Duby, V. 1

13. História de la Pedagogia de Abbagnano y Visalberghi.

14. As public school, eram instituições privadas que recebiam recursos da aristocracia inglesa com o intuito de formar os súditos ingleses para a militância antipapista. Receberam esse nome porque eram destinadas ao público em geral (a platéia?), pois as elites tinham suas escolas e não precisavam das mesmas.
} 
pelos ideais republicanos: faz parte do republicanismo educar seus cidadãos para exercerem e desfrutarem a cidadania.

Entretanto, a ação do homem sobre o homem ${ }^{15}$ - a influência, a ascendência, a autoridade - constitui o elemento primário de qualquer sociedade, não só das sociedades politizadas. O caráter específico da ação política, para diferenciá-la da ação social em qualquer das suas outras modalidades, está no fato que exige o concurso de outras pessoas, obrigando o seu promotor a pôr em jogo uma técnica de agrupamento de colaborações, onde a ação não é simplesmente individual e material, mas pressupõe um concurso de vontades voluntárias. Essa ação se torna essencialmente política quando tem por objetivo a formação do edifício humano, de forma agregativa, onde a ação de agrupar tem por objetivo final a boa existência do grupo. É legítimo definir a atividade política como a atividade construtiva, consolidadora e conservadora de agregados humanos que não escolhe apenas entre quantidades homogêneas de interesses, mas toma decisões, comparando termos e interesses heterogêneos, visando ao bem comum e ao particular de cada um, através de negociações públicas.

Enquanto atividade social ${ }^{16}$, a política se caracteriza por garantir pela força, fundada no direito e na autoridade (não no autoritarismo ou na violência), a segurança externa e concórdia interna de uma unidade de pessoas e território particular. No caso das democracias antigas e nas Repúblicas contemporâneas, um partido, um sindicato, um movimento social, uma ONG, algumas minorias, uma pessoa qualquer tem peso político, na medida em que tem a força para mobilizar um certo número de eleitores ou de pessoas para um projeto em comum. Salientemos, força não significa a posse de meios violentos de coerção, mas meios discursivos que permitem influir no comportamento de outra pessoa ${ }^{17}$.

\footnotetext{
15. Quem alerta para essa questão é Raymond Aron, no seu Estudos Políticos.

16. Essa faceta do poder político está eficientemente demonstrado no livro $O$ Que é o Poder de G. Lebrun.

17. Permita-me aqui, para aprofundar essa noção, me apropriar de uma idéia de Hannah Arendt que se encontra no seu texto Sobre a Violência. Diz a autora que o tema político mais crucial é, e sempre foi, a questão sobre quem domina quem e como se exerce essa função. Poder, vigor, força, autoridade e violência seriam simples palavras para indicar meios em função dos quais o homem domina o homem; são tomados como sinônimos porque têm a mesma função. Somente quando os assuntos públicos deixam de ser reduzidos à questão do domínio é que as informações originais no âmbito dos assuntos humanos aparecem, ou, antes, reaparecem, em sua autêntica diversidade. O poder corresponde à habilidade humana não apenas para agir, mas para agir em concerto. O poder nunca é propriedade de um indivíduo; pertence a um grupo e permanece existindo apenas na medida em que o grupo conserva-se unido. Quando dizemos que alguém está no poder, na realidade nos referimos ao fato de que ele foi empossado por um certo número de pessoas para agir em seu
} 
Em filosofia política ${ }^{18}$, a distinção mais difundida entre força e violência é a que denomina força às intervenções físicas justas, que preservam a ordem social ou perseguem o bem comum, e chama violência às intervenções físicas injustas, que destroem a ordem social ou impedem o bem comum. Na doutrina jurídica, tende-se a designar com o termo força as intervenções conforme a lei, e, portarto, lícitas, e com o termo violência as intervenções que violam as normas jurídicas, e são, portanto, ilícitas.

Isso significa que, toda oportunidade de impor a sua própria vontade no interior de uma relação social deve aceitar tanto as simpatias como as esistências, sendo a política a maneira de estabelecer os limites das oportunidades através de negociações públicas. Portanto, poder político significa a aplicação de uma capacidade generalizada em obter que os membros da coletividade cumpram obrigações le gitimadas em nome de fins coletivos, e que, eventualmente, permite forçar o recalcitrante através de sanções a se submeter a sua autoridade ou ao seu dever. Poder político é a possibilidade, por parte de um grupo ou pessoas, de limitar as opções de comportamento de outros grupos ou pessoas. Em seu significado mais geral, a palavra poder designa a capacidade ou a possibilidade de agir, de produzir efeitos. No entanto, não existe poder político, se não existe ao lado do indivíduo ou grupo que o exerce, outro indivíduo ou grupo que é induzido a comportar-se tal como aquele deseja. Logo, o poder não reside numa coisa, mas no fato de que existe um outro e

nome; sem um grupo ou um povo não há poder. Em seu uso corrente, quando falamos de um homem poderoso ou de uma personalidade poderosa, já usamos a palavra poder metaforicamente; aquilo a que nos referimos sem a metáfora é vigor. Designa algo no singular; é a propriedade inerente a um objeto ou pessoa e pertence ao seu caráter, podendo provar-se a si mesmo na relação com outras coisas ou pessoas, mas sendo essencialmente diferente delas. Força que freqüentemente empregamos no discurso cotidiano como um sinônimo da violência, especialmente se esta serve como um meio de coerção, deveria ser reservada às forças da natureza ou à força das circunstâncias, isto é, deveria indicar a energia liberada por movimentos físicos ou sociais. Autoridade é o reconhecimento inquestionável por aqueles a quem se pede que obedeçam; nem a coerção nem a persuasão são necessárias. Conservar a autoridade requer respeito pela pessoa ou cargo. O maior inimigo da autoridade é o desprezo, e o mais seguro meio para mina-la é a risada. A violência pode ser justificável, mas nunca será legítima. A violência sempre pode destruir o poder; do cano de uma arma emerge o comando mais efetivo, resultando na mais perfeita e instantânea obediência. O que nunca emergirá daí é o poder. Poder e violência são opostos; onde um domina absolutamente, o outro está ausente. A violência aparece onde o poder está em risco, mas deixada a seu próprio curso, ela conduz à desaparição do poder. Isto implica ser incorreto pensar o oposto da violência como a não-violência; falar de um poder não-violento é de fato redundante. A violência é capaz de destruir o poder; ela é absolutamente incapaz de cria-lo. O poder não existe necessariamente nem para sempre; nada é mais frágil do que o poder. Ele só existe enquanto as pessoas se consideram unidas num fazer comum onde se sentem co-autores e co-atores, além de platéia e público. Essa temática prosseguirá na próxima parte.

${ }^{18}$. Dicionário de Ética e Filosofia Moral, verbete Violência; Dicionário de Política, verbete Força. 
de que este é levado por mim a comportar-se de acordo com os meus desejos. O poder social não é uma coisa ou a sua posse: é uma relação entre pessoas.

Dessa forma, o poder político não é estar em condições de impor a própria vontade contra qualquer resistência, que deve mais apropriadamente ser denominado de força coercitiva, e pouca relação tem com o poder propriamente dito, que significa dispor de um capital de confiança tal que o grupo delegue aos detentores do poder a direção para a realização de fins coletivos.

Por mais que reduzam a política à dominação, à proibição, à censura, à repressão escancarada, ou pensar no poder político enquanto limitador, dotado apenas do poder do não, produzindo exclusivamente uma liberdade negativa ${ }^{19}$ que interdita os desejos, não se percebe o óbvio: o poder é mais o controlador de forças que seu produtor e organizador, sendo apenas a instância que constitui os cidadãos como sujeitos com vontades. Assim sendo, o poder político não é uma instância estranha ao corpo social, que está se opondo ao indivíduo, nem se deve interpretá-lo apenas como um puro limite imposto à liberdade.

Portanto, a política é a necessidade que aparece nas sociedades pós o advento da Grécia, ampliadas e requintadas com o transcorrer dos séculos, onde as regras de justiça têm força suficiente em si próprias para que os homens as respeitem, sem a necessidade da coerção, e quando existem grupos sociais com forte interesse em que a justiça seja ministrada de maneira segura. Uma comunidade política é um tipo de organização da "auto-dominação" baseada em consensos mínimos e fundantes, e não num amontoado de pessoas submissas ao domínio do governante, como ocorre em sociedades autoritárias. Logo, a partir da constituição política de um Estado tendem os homens a se acostumar à obediência cívica: o dever de obediência se enraíza por si próprio, e finda reconhecido como uma espécie de fatalidade ou natureza. Há muito tempo que ser cidadão significa ser obediente. Mas, que fique claro, obediência de forma alguma pode ser confundida com submissão. A obediência não deixa de ser uma virtude importante, ainda que não baste qua ndo é única.

Aliás, como salientado anteriormente, a política é coisa dos homens, como bem nos diz Aristóteles na Política, quando afirma que o homem é um animal político, tentando revelar nossa natureza e nosso diferencial. E complementa na Ética de Nicômaco que a política é

\footnotetext{
${ }^{19}$. Sobre o conceito de liberdade negativa é interessante o Estudos sobre a Humanidade de Isaiah Berlin, em particular, "Dois conceitos de liberdade".
} 
algo que exige disciplina, temperança, vontade, maturidade e bom senso, o que raramente se encontra numa só pessoa ou nas pessoas comuns. Entretanto, desde Platão e $A$ República, muitos acreditam e é difundido, que é preciso selecionar pessoas com tais características e colocá-las estrategicamente nos lugares chaves para abrir e fechar as porteiras para os humanos passearem entre outros sem que se machuquem ou machuquem alguém, e que também seja proveitoso para todos. Aristóteles ainda complementa: muitos homens são escravos por natureza e, quando se vêem livres dos grilhões, não dispõem de reservas morais nem intelectuais com que enfrentar a perspectiva de responsabilidade ou de uma escolha ampla entre várias alternativas. Tendo perdido os grilhões, saem inevitavelmente em busca de outros, ou forjam, eles próprios, novos grilhões. Onde não há escolha, não haverá angústia, haverá, isto sim, um feliz desincumbir-se de responsabilidade. Alguns seres humanos sempre preferem a paz do aprisionamento, uma segurança satisfeita, uma sensação de ter finalmente achado o seu próprio lugar no cosmos, optando por tudo isso aos dolorosos conflitos e perplexidades da liberdade desordenada do mundo, não querendo os riscos de se tomar decisões.

Assim, desde a Antigüidade é pensado que, para diversos tipos de pessoas, há diversas receitas e correções para sanar as doenças e alterar a rota dos interesses para que não se choquem. Para aqueles que têm uma natureza mais submissa, governantes fortes; para aqueles que têm espírito guerreiro, governos firmes, para aqueles muitos ignorantes, governantes sábios para dirigi-los. Para toda doença há um remédio, até os mais amargos como a ditadura, a tirania e o despotismo: quando a indisciplina e a algazarra são tantas, só a força, quando não a violência pura, pode conter multidões enfurecidas.

Pelo menos, é isso que nos ensinam os antigos, os medievais, os modernos e os contemporâneos ${ }^{20}$. Assim assistimos na prática diária da vida em comum e junto à coisa pública, e também no transcorrer da história. Ser assim não significa que tenha que assim ser. Tudo no homem é contingencial, produto de improviso, invenções, descobertas, acertos

\footnotetext{
${ }^{20}$. Há honrosas exceções, mas que não são levadas a sério dentro da política ou da filosofia política "hard". Considerados como movimentos ou pessoas realizadoras de uma atitude pessoal ou grupal mais do que proponentes de uma saída social, como se exige de toda política que não queira ser considerada "utópica", findam por vezes negligenciados. Os cínicos encabeçariam a lista, depois viria La Boètie e o seu Discurso da Servidão Voluntária, os libertários, Kant e sua filosofia moral, depois Nietzsche e sua filosofia do superhomem, os anarquistas, enfim, há pessoas que pensam a vida social e política onde a liberdade do homem não é uma dádiva do Estado, mas um exercício das pessoas, que ainda que dotadas de razão e liberdade findam por não exercem nem uma, nem outra a contento.
} 
e erros para todo lado: acidentes naturais e atmosféricos podem sempre mudar o curso da história, mas a história em si é sempre feita pelos homens. $\mathrm{O}$ verbo mais apropriado para designar ou descrever a humanidade é o estar. Talvez, a pergunta mais interessante a ser respondida não é "O que é o homem?", mas antes "Como está o homem?", "Onde está?", "Para onde vai?".

\section{2. - Sobre o Governo}

Naturalmente que o estado de natureza não é tão violento, não é a causa de uma propensão natural dos homens a fazer-se mal uns aos outros, não faz de cada homem um assassino potencial de cada um dos demais, como medrosamente ${ }^{21}$ pensava Hobbes. A ameaça principal à conservação da vida no estado de natureza não se encontra nas tendências dos homens a fazer danos uns aos outros, mas na pobreza e dificuldades de sua condição natural, e conjugam-se esforços para potencializar-se mutuamente para enfrentar dificuldades e obter fartura.

Mais que qualquer outro animal, o homem se encontra numa condição de indigência e debilidade. Necessita de alimento, vestimentas e refúgio. Encontra-se mal dotado por suas habilidades nat urais para satisfazer estas necessidades e assegurar sua possessão. Só a sociedade pode compensar essa debilidade. Ao unir sua força com a de outros, o homem é capaz de levar a cabo projetos para o que um só não tem poder suficiente; a divisão do trabalho propicia maior destreza nas artes e a ajuda mútua é um escudo contra o acidente e a má fortuna. Só em sociedade podem as necessidades humanas ser satisfeitas de forma mais fácil, durável e permanente, e ainda incluir novas necessidades que a criatividade humana e a sociedade mesma engendra.

Porém, conforme a sociedade vai se tornando mais complexa, com divisões de tarefas mais sofisticadas e especializadas, surge a necessidade da instituição de um Estado para coordenar a multiplicidade de pessoas e interesses. O Estado só começa existir quando o livre emprego de armas militares é vedado ao indivíduo e reservado a uma autoridade

\footnotetext{
${ }^{21}$. Sobre a questão do medo em Hobbes, leitura obrigatória é "Ao Leitor sem Medo" de Renato Janine Ribeiro.
} 
central, qualquer que seja seu tipo, e de igual modo a tributação da propriedade ou renda das pessoas concentra-se em suas mãos. Os meios financeiros arrecadados pela autoridade sustentam lhe o monopólio da força militar, o que, por sua vez, mantém o monopólio da tributação. É preciso haver uma divisão social muito avançada de funções, antes que possa surgir uma máquina duradoura, especializada, para a administração do monopólio. E só depois que surge esse complexo aparelho é que o controle sobre o exército e a tributação assume seu pleno caráter monopolista. Interessante notar que a partir desse momento os conflitos sociais não dizem mais respeito à eliminação do governo monopolista, mas à questão de quem deve controlá-lo, em que meios seus quadros devem ser recrutados e como devem ser distribuídos os ônus e benefícios do monopólio.

Platão, o primeiro a deixar ${ }^{22}$ um legado de reflexões sobre a política, fala que o bom governante deve ter prudência, a primeira virtude, mas também previdência, cuidado e conhecimento. Deve também ter temperança, que engloba honestidade, a sobriedade e a continência. Deve ainda ter fortaleza ou força de ânimo, capacitando-o a alcançar a magnificência na guerra e na paz, assim como constância e paciência em face dos assaltos da adversidade. E finalmente ter o senso de justiça, qualidade altamente complexa que se entende incluir liberalidade, caridade, amizade, respeito e anseio de concórdia. Enfim, talvez algo desumano ou pelo menos pouco avistado nas pessoas.

Por isso Platão salienta os problemas políticos e éticos que implicam viver sob governantes justos e bons, e nos alerta para o preço (impagável!) para uma vida justa na cidade ideal: separarmos os interesses do governo e governantes dos interesses particulares do cidadão comum ${ }^{23}$. Se os juízes, legisladores e executantes ou seus familiares têm todos interesses privados, esses acabam prevalecendo sobre os públicos quando da decisão dos governantes, numa cidade governada por homens, e o povo finda usado como meio e nunca como fim.

Ser governado por boas leis ou bons homens, eis a questão que o pensamento político coloca desde o seu surgimento grego, mas que findam os pensadores considerando ser preferível viver entre boas leis, tendo os homens como seus condutores e criadores,

\footnotetext{
${ }^{22}$. Ou será melhor dizer o primeiro a ser preservado pela posteridade?

23. A República, p. 159/160. A riqueza do governante advirá de suas ações e atinge apenas a alma, enriquecida em virtudes, nunca no vil metal. Entretanto, sabemos, são poucos que se satisfazem só com isso, e grande parte cede as atrações da riqueza material, eis porque parece utópico.
} 
nunca apenas como suas vítimas. Porém, ainda que as boas leis sejam o melhor objetivo para uma vida política mais fecunda, invariavelmente, debate-se mais os melhores governantes do que as melhores leis para os homens.

O mesmo Platão que mostra na sua República como seria a melhor cidade, onde a virtude reinaria sobre os vícios, ensina também o governante a mentir, induzir as pessoas a realizarem algo que a racionalidade revela mais benigno, quando prepara armadilhas para não perceberem a eugenia ${ }^{24}$ que está cometendo sub-repticiamente. Mesmo ele cria uma reserva moral, pois que sua mentira, acreditando que é para o bem comum, fará nascer homens mais fortes e sábios, grandes guerreiros e melhores ainda como governantes: dá início a falsa noção da nobre mentira. Creio que talvez tenha sido o primeiro a colocar em teoria a idéia de uma carreira pública para o Estado ${ }^{25}$.

O fato é que, não obstante os princípios metafísicos originários do agir e pensar político, colocados anteriormente, de que somos seres autônomos para agir em sociedade (autonomia advinda da liberdade e da racionalidade), um outro princípio metafísico impregnou a Política e também a filosofia política: são necessários freios a esse exercício da autonomia dos indivíduos, através de uma ação eficiente e enérgica de um condutor autorizado ou autoritário, enfim, algum governante. Novamente é Platão quem recebe a fama, a culpa ou o mérito por esse início ${ }^{26}$, quando na sua República pergunta quem é o melhor governante de homens. A resposta dada pelo pensador virou até piada, na medida em que desejava que filósofos fossem os governantes dos homens: o filósofo, todos sabem, desde Aristófanes ${ }^{27}$ e a sua As Nuvens, sempre está a andar nas nuvens e flutuando sobre o imponderável. Mas, se zombam da resposta, respeita-se muito a pergunta: quase todos tentam responder a questão: quem é o melhor governante? A esquerda ou a direita? Os

\footnotetext{
24. A República, p. 227/8.

25. É claro, sempre se pode desqualificar esse grande mestre, pois afinal, não estaria ele também protegendo a carreira dos Filósofos, criando um empreguinho público para o fim da vida? Conheço gente que não pensaria duas vezes em montar uma conspiração desse tipo para contar algum fato ou passagem da vida de um autor e assim desabona-lo em seus pensamentos. E quanto maior a grandeza do pensador, maior será o fato que o desqualifica em algum ponto de sua teoria.

26. Nietzsche e Arendt também culpam o filósofo por tornar a filosofia contemplativa e negligenciar as forças vitais dos homens. Entretanto, creio que há em Platão antes que uma negligência, um excesso zelo ou temor dês

sas forças.

27. Escreveu antes de Platão, o que pode significar que na própria época os dizeres de Platão devem ter sido motivo de zombaria.
} 
social-democratas ou os liberais? Os progressistas ou os conservadores? A democracia, a aristocracia ou a autocracia? Todavia, poucos perguntam: é necessário que haja governo?

Tal pergunta não ocorre porque há um princípio aceito pela quase totalidade do pensamento político desde Platão, ainda que pouco manifestado, e na maior parte das vezes omitido. Visto que nunca se encontrou vida política sem um governo, decorrem desse fato histórico e cultural, uma natureza no homem e, conseqüentemente, na política. Bem platonicamente, boa parte do pensamento político ocidental introjetou um ideal do homem dividido em duas instâncias: o vulgo e a elite, sendo a grande maioria das pessoas vulgas e incapazes de fazerem as coisas certas e necessitam de um condutor sábio (Platão), ou ético (Tomás de Aquino), ou astuto (Maquiavel), ou carismático (Hegel e seu homem histórico catalisador das vontades da sua época), ou um partido (Marx), ou um regime político (a democracia), enfim, alguém ou algo capaz de conter os desejos ilimitados do povo.

Assim, desde a Antigüidade, para a elite, o povo e/ou a plebe não tem capacidade, nem virtudes políticas. O povo não é uma instituição jurídica, mas antes amontoados de pobres desejosos dos bens dos ricos, gerando o grande e eterno medo do confisco da parte pobre da sociedade sobre a parte rica da mesma: seria injusto e tirânico a população pobre valer-se de seu número para decretar, numa assembléia, a expropriação da riqueza dos poucos, bradam quase todos os autores. O mais provável é que todos ficariam pobres! Todos os autores concordavam que a necessidade de liderança política era axiomática; seu problema era saber quais os tipos de lideranças eram bons e quais eram maus.

Por trás dessa formulação jazem três pressuposições: 1) os homens não são iguais, seja em seu valor e idoneidade moral, seja quanto ao seu status socioeconômico; 2) qualquer comunidade tende a se dividir em facções, sendo que as mais fundamentais dentre elas são as dos ricos e bem- nascidos, de um lado, e os pobres do outro, cada uma com suas próprias qualidades, potencialidades e interesses; 3) o Estado bem ordenado e bem governado é aquele que supera as facções e serve como instrumento para uma vida digna: o bem-estar do Estado repousa na harmonia e/ou ausência de facções! Os autores antigos insistem que o Estado deve ficar afastado ou acima dos interesses de classe e/ou facciosos. Seu fim e objetivo é moral, atemporal e universal, e só pode ser atingido pela educação, pela conduta moral, por uma legislação moralmente correta e pela escolha de governantes apropriados. 
No mundo contemporâneo, avista-se que alguns princípios da democracia das cidades gregas prevaleceram na estrutura herdada do Estado republicano romano. Hoje grandes maiorias elegem aqueles que ditam leis e executam supostos interesses comuns, formado no calor do momento e para satisfazer em grande parte apenas necessidades imediatas e imediatistas. Creio que o nome mais apropriado para isso seria pluripartidarismo, mas denomina-se democracia representativa. Mesmo tendo o jeito ou a aparência de que, senão a mais certa, é a forma menos errada e menos injusta, mais "humana" 28 e decente de governar homens, devem os homens ser governados? Ou, colocando sob outro aspecto, deve existir algum tipo de instituição para coagir as pessoas a realizarem o certo ou impedir ${ }^{29}$ o errado? A pergunta platônica sobre o melhor governante não teria por acaso deslocado a política ocidental, na medida em que tem se buscado os melhores governos e governantes, quando antes seria necessário justificar por que da necessidade de sermos governados? Não teria o governo se transformado em si mesmo um fator de morte da vida política, substituindo a liberdade de escolhas autárquicas pela administração dos interesses econômicos da sociedade?

O grande problema que a democracia apresentou (e apresenta!) é o risco constante de ocorrer uma tirania da maioria sobre a minoria, transformando a convivência das diferenças de interesses (que é uma das virtudes da democracia), numa submissão à vontade de uma maioria inconstante, volúvel, imediatista etc., das diversas minorias existentes. Que o medo seja justificável tanto na história como no presente, na medida em que inúmeras vezes que massas humanas se juntam sem lideranças ou sem tutela, lincham, colocam fogo, derrubam, viram, destroem, enfim, agem mais como uma nuvem de gafanhotos do que uma colméia polenizadora, este medo parece perder sua legitimidade com o advento do Iluminismo. Não sei se subiu o conceito do povo no pensamento das elites, mas parece certo que se amenizou o preconceito contra o mesmo.

O fato é que desde Maquiavel, passando por Hobbes, até a atualidade há uma corrente majoritária, associada ao "realismo" político, que desenvolve a mentalidade da prática política como um exercício essencialmente amoral, e muitos ainda consideram que

\footnotetext{
28. As aspas justificamse porque todas as atitudes, atribuídas aos homens e tidas como desumanas, são absolutamente humanas e só homens as praticam. É que se acredita que só as coisas dignas são humanas e as indignas são de animais. Não é verdade, os animais não conhecem a intensidade do ressentimento, rancor, raiva ou ódio, muito menos a crueldade e a maldade, nem podem ser dignos nem indignos.

29 . Tentar, é claro, como é mais correto pensar.
} 
ela nada tem a ver com a ética. Sim, acredita-se na racionalidade humana, que há potencialidades nos homens, que bastam apenas alguns esforços educacionais para todos serem adequadamente cultivados para que frutifiquem como pessoas e cidadãos. Mas, impera também o empirismo elementar de assistir diariamente as pessoas perderem a cabeça, mesmo educadas, por questões pequenas e banais.

Acrescentemos ainda que desde a Antigüidade as definições sobre o homem saem de escolas filosóficas e científicas, e muitas parecem buscar mais que um entendimento, uma superioridade da espécie com relação ao resto do mundo animal, vegetal e mineral, ou até mesmo de outros homens tidos como inferiores. Pecam as definições seja por um antropocentrismo, sja por um etnocentrismo, seja por preconceito de classe e função social, egoísmo, mesquinhez, querendo por vezes revelar mais a superioridade ou a dignidade de quem exerce o direito de definição do que do objeto definido. Conceituam o homem como um animal racional, político, social, sábio, dando uma aura de genialidade, magnanimidade, honras e nobreza de alma ou espírito para a espécie.

Todas essas definições de maneira geral cometem o mesmo equívoco da famosa definição da academia platônica denunciada pelo cínico Diógenes, que ao definir o homem como "bípede implume", permitiu a suprema ironia do cínico de depenar uma galinha e jogar no meio da academia, e bradar: "Eis aqui o seu homem!". Ou seja, essas definições pecam por não captar o atributo essencial da espécie. Poderia jogar um louco ou alguém com debilidades mentais sérias aos acadêmicos que definem o homem como animal racional. Poderia pegar um índio que desconhece a vida política, pois que tem uma vida comunitária antes que social, e mostrar que há homens que não são políticos. Poderia pegar um ermitão e trazê-lo para a academia para mostrar que há homens que não são sociais. Deixaria algum deles de ser homens? Se houver definição da natureza ou "essência" do homem, tal definição só poderá ser entendida como sendo funcional, e não substancial. A característica destacada do homem, sua marca distintiva, não é a sua natureza metafísica ou física, mas o seu trabalho e a sua ação, enfim, o sistema de atividades humanas que define e determina o círculo da humanidade. Linguagem, mito, religião, arte, política, cultura, ciência e história são os constituintes e os vários setores desse círculo.

Que o homem possa ser sábio eventualmente, utilizar a racionalidade em determinadas situações de sua vida, que tenha vida política em alguns momentos e que viva 
em sociedade, uma outra característica que parece distinguir - outra função que cumpre nossa espécie é a capacidade de troca, seja de esforços, seja de idéias, seja de mercadorias, seja de bens, de afetos, de emoções, enfim, de qualquer coisa, e não apenas entre pessoas, mas com o mundo ao redor. Ou seja, o comércio ${ }^{30}$ nos distingue de outros seres tanto quanto as outras características. Temos, enquanto espécie, muitas potencialidades, mas nem sempre individualmente podemos efetivar todas, e nem todas que efetivamos serão realizadas da forma mais apropriada ou correta. No caminho da aprendizagem erra-se muito, e erros devem ser primeiramente corrigidos quando possível, nunca punidos.

A nação que não consegue participar do comércio se caracteriza por uma superstição inata, por prejuízos e ignorância, assim como por costumes bárbaros. O comércio dá as bases para sair da mentalidade localista. Favorece a comparação de diferentes formas de vida. Faz possível o questionamento de crenças atávicas. Permite aos homens descobrir mais sobre a natureza. Em suma, faz possível a busca coerente ou consciente do conhecimento sobre a natureza e o homem: os efeitos do comércio são a suavização e o refinamento dos costumes bárbaros, o estímulo às artes e às ciências, a condição até a paz pela vinculação das nações, mediante suas necessidades e a elevação do nível de vida. Os maiores benefícios do comércio são os menos óbvios, as consequiências não buscadas do egoísmo do mercador.

Comércio aqui deve ser entendido no seu sentido mais amplo, não apenas de trocas materiais, de mercadorias, mas de trocas emocionais, espirituais, de idéias. A troca entre as pessoas une pessoas e grupos distintos. Os problemas começam a ocorrer quando ao invés de procurar trocar serviços, idéias, sentimentos, coisas em geral, se quer tomá-las à força, ou roubar, usurpar, ou enganar, ludibriar, impor. Eis um passo decisivo para a igualdade entre os homens: todos realizam trocas. Povos distintos em todas as épocas foram desenvolvendo a tolerância, a compreensão do próximo, trocando informações e dados

\footnotetext{
${ }^{30}$. Naturalmente, não estou propon do uma nova definição do homem como um animal comerciante, mesmo porque Adam Smith já fez essa proposta no clássico a Riqueza das Nações. Minha preocupação é recuperar essa característica que tem sido desde sempre o canal das inter-relações humanas entre seus grupos distintos, promovendo a globalização humana que ocorre desde a Antigüidade (ainda que só tenha adquirido maior visibilidade no último século), e promovendo algo que potencializa a todos, e que desde a Grécia recebe uma aura de negatividade, de uma coisa menor, menos sublime, por ser considerada uma atividade serviçal ou banal, interesseira, que foi negativada ainda mais pelo cristianismo, condenando o comércio como atividade de usura e de moral duvidosa, e que serviu também às correntes socialistas para estigmatizar uma prática que permite o enriquecimento, sempre entendido como algo ilícito, indigno, maldoso e que visa apenas a exploração de pobres inocentes.
} 
culturais através das trocas materiais e espirituais, e criando as relações internacionais que hoje estão potencializadas pelo desenvolvimento tecnológico, que parece um fenômeno novo, a globalização, mas que sempre ocorreu através das trocas: apenas hoje as trocas são mais rápidas e instantâneas, devido a um enriquecimento material, tecnológico e cultural que pertence e envolve a espécie. Quanto mais trocas os povos e as pessoas realizam, maior é o seu crescimento cultural, a sua expansão pela Terra.

$\mathrm{O}$ fato de parte importante do pensamento político ${ }^{31}$ ver o comércio como uma atividade menor (com exceção, é claro, dos liberais e de alguns outros Iluministas como Montesquieu ou Voltaire), ou como uma coisa indigna, porque visa apenas o consumo imediato e não grandes obras culturais e eternas, ou mesmo como algo maldoso que propõe apenas ludibriar o outro ou o lucro extorsivo, é decorrente de uma moralidade que aos poucos vem sendo superada pela ampliação da laicização e tolerância da vida social e humana (pela crescente consciência de uma igualdade aceita racionalmente, ainda que negada muitas vezes intimamente), ou seja, pela crescente politização da vida. O comércio é um fator civilizador que amplia os laços, sendo por ele e através dele que a humanidade vai criando instituições e instrumentos que garantem (ou buscam garantir, o que nem sempre ocorre, ou ainda nunca tenha ocorrido) a tranqüilidade e a justiça nessas trocas, e vem aumentando sua tolerância com grupos humanos diferenciados. As guerras aparecem quando alguém ou algum grupo se considera com força suficiente para romper as regras instituídas por práticas comuns e impor as próprias, ou usurpar os próximos, quando se rompe a troca e se apela para a conquista ${ }^{32}$, ou por questões de ordem religiosa, as mais comuns.

\footnotetext{
31. Nas Repúblicas antigas, costumava-se pensar que pessoas totalmente envolvidas no mundo da troca de mercadorias e da divisão de trabalho eram moralmente instáveis e frouxas: o mergulho nessas atividades induziam-nas à corrupção de suas virtudes políticas e militares, isto é, a perda do interesse em zelar pelo bem comum e da vontade de defender a pátria pessoalmente, empunhando armas. Não eram próprias ao bom cidadão-miliciano. Cabia às instituições políticas zelar para que a cidadania não se entregasse a essas atividades a tal ponto que acabasse dependente delas.

32. Nesse sentido, o capitalismo, o sistema comercial contemporâneo não é nem moral, como afirmam muitos liberais, nem imoral, como afirmam as esquerdas, mas amoral, ainda que possa ser utilizado de uma ou de outra forma, pois que é apenas um instrumento. Sua moralidade advém do uso que se faz e não do instrumento em si. Assim como um martelo pode ser utilizado para construir uma casa, ele pode ser utilizado para matar uma pessoa, mas ele próprio foi criado para facilitar a vida, não para usos morais ou imorais: com certeza é mais fácil construir uma casa, assim como matar uma pessoa, com um martelo na mão do que com as mãos nuas. O mesmo ocorre com o comércio, sua função é facilitar a vida e satisfazer vontades, e vendedor e comprador podem realizar trocas onde ambos saem ganhando, mas pode ser realizado trocas desiguais: $o$ comprador sabendo da dificuldade do vendedor de vender a mercadoria pode forçar que a mesma seja vendida
} 
A verdade é que o comércio ${ }^{33}$ é um dos elementos fundamentais que une, civiliza; é o que globaliza, mundializa. Essa capacidade de troca de interesses, que pode se tornar perfeita quando ambos saem ganhando, é também a capacidade de potencializar os esforços mútuos individuais ou coletivos, que faz construir coisas que não apenas possuem um lugar no espaço, mas que duram no tempo, que têm permanência, e servem de veículo da imaginação e de educação de novas gerações que estão sempre refazendo, re-significando, remodelando. Essa potencialidade de comercializar permite guardar os dados, trocar informações, criar laços e vínculos fortes, elos que unem não apenas as pessoas individualmente, mas principalmente lugares e épocas. Essa possibilidade de ir trocando as coisas é mais um dos elementos que distingue o homem dos demais animais, que podem apenas se apropriar delas para si próprio por força ou astúcia, enquanto os humanos conseguem também trocar livremente seus esforços e conquistas para benefício mútuo. Portanto, o comércio entre os homens é um dos fatores essenciais que garante a civilidade, as trocas que nos enriquecem como pessoas e como possuidores, e é um traço marcante que nos caracteriza e nos diferencia: a capacidade de trocarmos esforços, potencializando nossa capacidade de satisfazer desejos e vontades, em sua maior parte artificiais.

O fato significativo é que o homem fabrica objetos, mas não apenas os produz na privacidade do isolamento, mas também para a privacidade do uso, da qual os produtos emergem para adentrar a esfera pública do mercado de trocas. É somente no mercado de trocas, onde todas as coisas podem ser trocadas por outras, que todas se tornam valores, quer sejam produto do trabalho, quer sejam objetos de uso ou de consumo, necessários à vida do corpo, ao conforto da existência ou à vida mental. Este valor consiste unicamente na estima da esfera pública, na qual as coisas surgem como mercadorias, e o que confere esse valor a um objeto não é nem o trabalho, não é o capital nem o lucro nem o material,

por um preço inferior ao seu mérito, ou o vendedor sabendo da extrema necessidade do comprador do seu produto, pode pedir muito mais do que ele vale. Isso não é uma decorrência imediata e direta do comércio, mas fundamentalmente de problemas éticos e políticos das sociedades e/ou das pessoas.

33. O termo comércio é tão comprometido que se faz necessário algumas explicações. Em primeiro lugar, o comércio é uma instituição humana, já o comerciante é uma especialização social de diversas sociedades. Na sociedade contemporânea, há inclusive distinções possíveis de serem feitas entre o pequeno e o grande comerciante, aquele que tem uma banca na feira e aquele que é dono de uma rede de supermercados. Entretanto, a quantidade de comércio não altera a qualidade da ação, apenas quando há intenções danosas do comerciante, mas daí tanto faz ser grande ou pequeno. Em segundo lugar, o comércio é uma atividade eminentemente pública, apesar de raramente ser estatal, é uma relação social, humana e diz respeito aos interesses privados dos membros da humanidade, entre alguém que quer vender e outra que quer comprar algo. A publicidade do comércio será abordada melhor na próxima parte. 
mas única e exclusivamente a esfera pública, na qual o objeto surge para ser estimado, exigido ou desdenhado. O valor é aquela qualidade que nenhuma coisa pode ter na privacidade, mas que todas adquirem automaticamente, assim que surgem em público. Ao contrário das coisas, dos atos ou das idéias, os valores nunca são produtos de uma atividade humana específica, mas passam a existir sempre que os objetos são trazidos para a relatividade da troca, em constante mutação, entre os membros da sociedade ou entre sociedades.

É óbvio que se pode discutir se essa capacidade de comercializar é decorrente da racionalidade, da liberdade ou da vida política, ou por sermos seres sociais, enfim, dos atributos clássicos à espécie. Entretanto, não tenho uma preocupação metafísica de saber quem nasce primeiro, o comércio ou a racionalidade, ou algum dos outros atributos disseminados pelo senso comum e acadêmico, destinados à humanidade. Apenas saliento mais uma faceta humana, muito negligenciada desde a Antigüidade e estigmatizada por inúmeras correntes de pensamentos antigas, medievais e modernas importantes e atuantes, que forma a opinião pública e acadêmica. Mas, acredito que se deve dar também uma atenção especial para essa peculiaridade humana de poder trocar, comercializar, dos afetos aos bens materiais, e mostrar que trocas injustas, ou a usurpação de bens e afetos são grandes causadores dos imensos problemas passados e presentes na convivência humana. Entre outros motivos, porque é preciso ensinar os homens a negociar para não sair perdendo nos negócios públicos, ou usurpar o próximo, e tirar o lado de inferioridade e coisa menor do comércio entre os homens. Só há pleno exercício da liberdade quando se supera as necessidades básicas naturais e artificiais, o que só é possível através de trocas.

Mas, há um problema diretamente relacionado com essa depreciação do lado comercial do negociante do ser humano, que resulta que se pense os homens não como iguais, mas com valores e capacidades não apenas diferentes, mas hierárquicas entre inferiores e/ou superiores. Assim como o comércio é uma atividade considerada menor, as pessoas que o realizam também são consideradas inferiores ${ }^{34}$. Cria-se uma hierarquia social, onde se considera uns mais dotados e a grande maioria menos dotada. E está dado o

\footnotetext{
34. Naturalmente, o status dos comerciantes subiu muito nos últimos três séculos. Mas, ocorre que há um momento que se passa de comerciante a empresário. A esse último se destina uma dignidade maior que ao pequeno comerciante. Temos hoje a figura do empresário, do investidor e do especulador que são vistos como superiores aos demais ofícios.
} 
passo fundamental para a existência dos governantes que têm a função de administrar os homens menos dotados da sociedade. Agricultores, comerciantes, artesãos, serviçais de uma forma geral findam como atividades menores na sociedade, e as pessoas que exercem esses ofícios são consideradas inferiores e subalternas: elabora-se uma hierarquia de importâncias sociais variadas, onde tais atividades ficam destinadas a pessoas consideradas inferiores. O governo fica destinado àqueles que se colocam (e também são assim considerados!) como superiores, e com distinção sobre os demais.

Ora, a igualdade é mais um ideal do que uma efetividade, isso desde os gregos que iniciaram essa visão do Homem. A partir de Platão os homens em geral são incapazes de governarem a cidade e fazem-se necessários alguns poucos homens mais dotados desta nobre "arte" ou "ciência" da política para administrar a vida pública. O fato é que não se consegue sentir, ainda que se pense, a igualdade. Parece haver pessoas superiores e inferiores, comandantes e comandados, governantes e governados como se fosse um fenômeno natural, da biologia ou da psicologia das pessoas. As vir tudes, por vezes, são consideradas inatas. Enfim, existe a crença difundida que, sem forças coercitivas a direcionarem os homens, os mesmos são levados por apetites vigorosos e tirânicos, se deixando afogar pelos desejos primitivos e egoístas, havendo o caos e a dissolução social. Crença antiga e profundamente arraigada na mentalidade ocidental ${ }^{35}$.

Dessa forma, procura-se pessoas gabaritadas para exercerem o "nobre" ofício de governante. Acredita-se que os homens, em sua maioria, precisam ser liderados e coagidos para que encontrem a virtude pública e social; os poucos que não precisam de líder, devem sê-lo dos demais. Ainda que por vezes visionários, a maior parte dos humanos ainda não consegue visualizar para além dos seus interesses próprios, tornando-se, dessa forma, mesquinhos, egoístas, avaros, e, pior, acreditando que todos são assim; e todos assim se tornam. Faz coisas escondidas, clandestinas, secretas, visando a si próprio e em prejuízo dos demais.

Porém, há também sempre alguém mais vaidoso que acredita poder governar os homens, que se mostra como dirigente de homens e acima dos defeitos comezinhos.

\footnotetext{
35. Há uma passagem na República de Platão muito instrutiva, quando se introduz um mito para que as pessoas possam se acomodar nos seus afazeres "menores": "Vós sois efetivamente todos irmãos nesta cidade" - como diremos ao contar-lhe a história - "mas o deus que vos modelou, àqueles dentre vós que eram aptos para governar, misturou-lhes ouro na sua composição, motivo por que são mais preciosos; aos auxiliares, prata; ferro e bronze aos lavradores e demais artífices." P. 157.
} 
Acredita que sabe o que é o certo e o justo, o que é necessário, que sacrifícios colocar aos demais e que bens realizar para todos. Isso tanto na esfera prática realizada pelos líderes políticos como na teórica concretizada no pensamento político ocidental. Sempre há uma presunção de achar que há pessoas superiores e inferiores na sociedade, que há uma pobreza espiritual generalizada pela massa da população (da qual, naturalmente, estão excluídos por algum tipo de superioridade intrínseca), que as pessoas são boas ou más, capazes ou incapazes, uns mais dotados, outros menos dotados, enfim, um conjunto infinito de pares de opostos entre virtudes e vícios, entre os quais, algumas virtudes são supervalorizadas em detrimento de outras, e alguns vícios subvalorizados em contraposição a outros supervalorizados. Valorizam arbitrariamente as diferenças humanas, gerando uma visão de desigualdades: o potencial de liberdade e racionalidade torna-se uma utopia, onde só alguns poucos privilegiados conseguem exercer não só para si, mas (sic!) pelos demais!

Entretanto, o absurdo é considerar que a reconciliação de todos os homens há de sair de pessoas que não sejam esse mesmo homem, ou seja, um inferior. Se o ser humano é egoísta e prepotente por natureza, uns são mais capazes que outros, mais esforçados que outros, mais ambiciosos que outros etc. Quem garante que aquele que diz que só tem virtudes, que não é tudo isso de ruim que os homens em geral possuem, não seja ruim também? Há quem disponha de um instrumento para medir o tamanho real das pessoas, captando mais que seu aspecto físico e suas aparências?

O que nos dizem os homens, os pensadores da humanidade, através dos tempos sobre a política, senão que dela se usa com a astúcia da raposa, a força do leão ${ }^{36}$, a precisão de uma ave de rapina e um mimetismo camaleônico que faz com que as ações governamentais injustas sejam pouco ou nem notadas? Não está tudo numa concordância forjada em aparências, com pessoas interesseiras tão somente? Onde há ou houve dignidade na política senão nos utópicos (e mesmo esses sempre cativaram a ilusão de alguma forma de controle sobre os homens ignaros do povo)?

No entanto, o que se vê por aí? Qualquer pessoa andando pelas ruas de uma cidade qualquer, em quase todo o mundo ocidental, nota que a maior parte das pessoas é boa, no sentido muito preciso - mas suficiente para o intercurso social - de que convivem razoavelmente bem com os demais cidadãos, familiares, clãs, enfim, o lugar comum em

\footnotetext{
${ }^{36}$. O Príncipe de Maquiavel seria o grande paradigma.
} 
todas as partes do planeta. Aliás, pode-se hoje andar por qualquer parte do mundo Ocidental sem problemas, sendo aceito até como diferente, estrangeiro, mas identificado como um ser humano, apenas que de outro lugar e com outra língua. Isso pode parecer muito pouco para muitos, principalmente aos mais jovens e incultos. Mas, se pensarmos historicamente, isso é muito recente. Há cem anos atrás seria inimaginável a segurança alimentar, médica, educacional, habitacional e de ir e vir por aí sem ser molestado nos deslocamentos. Enfim, parece que a maior parte das pessoas cumpre a lei e seus deveres não por medo a ameaças, mas por algum tipo de confiança mútua.

Fundamentalmente, parece que as pessoas são iguais em potencialidades para o bem e para o mal em toda parte e em todas as instâncias, e não existe garantia alguma que alguém mais dotado em inteligência, cultura, conhecimento, sabedoria ou outra virtude qualquer, tão enaltecida desde a antiguidade, possa ser nelhor ou pior no exercício do poder político do Governo. Parece que as pessoas se auto-governam mais do que são governadas seja pelo governo, seja pela coerção, seja pela religião ou por algum outro tipo de poder externo.

Essa visão de superioridade e inferioridade, de virtudes e vícios, de certos e errados, de vulgo e elite, enfim, todas essas categorias criam realidades de lutas, de contraposição, de conspiração, de enganos mútuos, de luta e morte sobre certos e errados, além de hierarquias sociais. Com tais categorias constróise uma realidade muito simplista e pobre para descrever em sua riqueza a vida pública dos homens em sociedade. Ora, ser dessa ou daquela classe social, dessa ou daquela profissão, ter essas ou aquelas qualidades e virtudes, apenas é cumprir uma função social interdependente e coativa para a construção da realidade política e econômica de algum lugar e só durante algum tempo: até mesmo os inúteis, os imprestáveis, os "maus", criam a necessidade de combatê-los, apoiá-los, amparálos, e com isso geram empregos e bens sociais.

Nunca é demais alertar que o mundo construído por essa forma de pensar, está atrelado à redução da visão e (in)sensibilidade(?) dessas categorias. Ver o mundo como uma luta entre o bem e o mal reduz a vida a uma coisa dupla, findando por ser ambígua e morrendo ao fim, na relatividade das contingências. Matar é proibido, mas pode ser feito em legítima defesa. Roubar é errado, mas se justifica quando se está com fome. E o problema, no entanto, é outro. Por que há pessoas com fome? Por que há pessoas que 
matam? Não estão os homens governados? Como continuam a existir as agressões mútuas? Que barbaridade é essa que ocorre ao educar os homens para a convivência, que não consegue eliminar a visão do crime, e ele continua a ocorrer como uma mera banalidade capaz de ser cometido por motivos torpes, principalmente pelos governantes?

Ora, a questão importante é que a condição humana não é a mesma coisa que a natureza humana, pois se o ser humano fosse dotado de uma "natureza" m sentido forte pressuporia condições prováveis e invariáveis, condicionamentos, previsibilidade, mas o fato de ser o homem o arquiteto de seu futuro, do seu presente e do seu passado comprova a imprevisibilidade que avistamos no mundo humano, o que permite supor que a biologia humana está secundarizada pelas atividades culturais que inauguram ações antes inexistentes. Sendo o homem um ser que age, o futuro é incerto, e está aberto à infinda criatividade humana.

As transformações históricas e sociais que ocorrem da antiguidade até os dias de hoje têm como linha condutora, não uma necessidade natural, mas uma decorrência de ações realizadas no meio social, da capacidade de criar e fabricar coisas que não existiam anteriormente à criação e à fabricação, assim como da capacidade de instrumentalizar o mundo e criar ferramentas, tornando os homens em fazedores de objetos artificiais e meios de sobrevivência, assim como de ações originais.

$\mathrm{O}$ advento da modernidade e as transformações que ocorreram no pensar e agir ocidental arremessaram os homens para o seu eu interior, fazendo com que a preocupação com o ego superasse a preocupação com o ser humano em geral, retirando certezas tão arduamente buscadas desde a antiguidade clássica sobre o mundo, atingindo não apenas as concepções de natureza, mas abarcando também os homens e a sua moralidade. A ação superou o pensar em importância e relevância. Para pessoas que estão voltadas só para si e para os seus interesses, sem muitas vezes julgar o valor ético, quando não desconhecendo esse aspecto dos interesses e atos, ou nem ao menos querendo pensar a respeito, parece evidente que sem o advento de um governo a vida social se tornaria um caos, o que até pode ser verdadeiro, mas nem por isso torna necessário que assim seja. Nada do que é e parece sempre ter sido, continuará a assim ser para sempre: sempre é mais um termo da linguagem do que propriamente um evento da realidade. 
A governabilidade dos homens não é uma necessidade, é uma contingência; não decorre da natureza humana, mas das condições que instituiu. O governo é um instrumento arcaico de dominação social que aparenta concretizar o poder político, materializando-o para as pessoas (é mais simbólico do que efetivo). Sua permanência amplia os custos sociais e político da convivência humana, possuindo interesses próprios (e caros), cuja função hoje tem resultado mais em manobrar interesses, que se fazem valer pela sua força política. O gasto com sua segurança em muito supera o gasto com a segurança dos cidadãos, e o seu custo operacional para aparentar saber resolver e/ou resolver de fato problemas sociais (nada mais vago), é maior que os custos propriamente dito dos problemas a que se propõem resolver. Na verdade, o governo mais provoca problemas, torna desigual o embate dos interesses sociais, aliando-se e privilegiando uns em detrimento de todos. $\mathrm{E}$ enquanto se luta por mudanças governamentais, buscando os partidos políticos apenas tomarem o Estado para impor políticas econômicas, sociais e educacionais, se fortalecem os Estados, enfraquecendo a sociedade civil.

\section{3 - Uma Política de Massas}

A confluência humana é uma realidade antiga e que vem sendo alertada de suas implicações pelo menos desde Kant, tanto na Paz Perpétua como na Idéia de História Universal do Ponto de Vista Cosmopolita. No século XVIII, já alertava o filósofo, que as ações humanas estão se estendendo por lugares muito mais longínquos do que o imediato e mais à vista. Que o crescimento populacional e a sofisticação dos armamentos tornam necessário que se crie instituições que abarquem os Estados e os cidadãos do mundo, para que não se prejudiquem mutuamente ${ }^{37}$ : uma federação de Estados sugere Kant. Ora, como o planeta não cresce fisicamente e a expansão humana pelo mundo, com o crescimento

\footnotetext{
37. Kant descreve um fenômeno interessante. Durante séculos os esquimós viveram das madeiras das árvores que caiam nos rios europeus que desembocam no Atlântico Norte, e através de correntes marítimas, as mesmas chegavam aos habitantes dos pólos. Era evidente para ele que, ao se cortar as florestas na beira dos rios europeus para o progresso ou mesmo por simples necessidade nos níveis e da forma como ia sendo realizado, iria acarretar em prejuízos futuros para os mesmos. Para que isso não acontecesse, para que o estrago local não prejudique alguém mais distante, para que envenenamentos das águas não fossem prejudiciais ao mais distante, nem que a sujeira e imundice de cima chegue aos povos que moram no meio e fim dos rios, só criando leis e princípios internacionais.
} 
populacional, não é indefinida, pelo contrário, tem limites e demarcações bens estreitos (o tamanho do planeta), há que se criar sistemas de convivência humana, para que nem cessem os recursos naturais por abusos, nem cerceiem o direito dos homens aos recursos naturais, nem se matem pelo espaço físico.

Nacionalidades se tocam, fazem fronteiras, tangenciamse. A paz interna de uma República não depende apenas de suas intenções virtuosas, é preciso a confluência de interesses com os demais Estados para que não resultem guerras, ou desgraças naturais e humanas. Em particular as guerras, desde a época de Kant, tendem a sofisticar armas de destruição em massa, colocando as pessoas em risco, podendo ocorrer vitórias, mas sem vencedores e com ausência, pela extinção, de derrotados.

Acrescentemos ainda o fato de que hoje muitos princípios, interesses e bandeiras de luta são internacionais, quando não globais, pois fronteiras físicas ou geopolíticas são coisas ultrapassadas desde meados do século passado (barra-se mais as pessoas que produtos ou ações) em muitos pontos da produção cultural, econômica e política do mundo atual. Pensar a política apenas como um fenômeno nacional é um tipo de arcaísmo persistente.

Não queremos dizer que não haja problemas nacionais ou na política naciomal, apenas que problemas e soluções não estão apenas no âmbito nacional e dependem em grande parte de grandes negociações internacionais. Oceanos, montanhas, solos e subsolo do planeta precisam ser compartilhados, e não meramente explorados até a exaustão por quem está mais próximo desses bens, pois extinção de espécies e de meio-ambientes é algo que diz respeito à humanidade e não apenas a uma nação, um povo ou um indivíduo.

Além disso, os interesses não são mais apenas os de classe, como se supôs por muito tempo pensamentos influenciados por Marx, mas de pessoas e grupos, que independente dos interesses econômicos e sociais da classe a que pertençam, têm também laços com interesses multifacetados que estão espalhados indiscriminadamente por todas as classes, grupos, pessoas, quiçá, pelo mundo. O conceito de classe é uma categoria que não retrata na sua integridade a realidade contemporânea, cujos interesses se formam não apenas à volta dos interesses econômicos, mas por interesses de ordem cultural, política, social, individual, religiosa, de massas etc. $O$ fato é que as pessoas formam massas de interesses com força institucionalizadora de tendências e efetivação de novos costumes e 
gostos. Verdade que são mais temporários, quase instantâneos, e esvoaçam logo depois, às vezes, nem deixam lembranças ou se deixam, a mesma é negativa. Por vezes, é melhor esquecer. Lembremos de Hitler, sempre um grande paradigma!

Os partidos políticos que até o momento se preocupam em captar os "interesses sociais" dos nacionais, no fundo mais os enunciam, ou os constroem, do que os representam. Eles não representam interesses sociais disseminados pela sociedade, mas antes interesses de grupos particulares que se articulam para a obtenção do poder, ou melhor, da força do Estado. As ideologias são fracas, as diferenças programáticas são mínimas, os objetivos políticos quase sempre restritos a um reduto de interesses particulares são os mesmos: a governança. O fato é que a pluralidade política nas democracias é um mito: escolhe-se entre uma variedade do mesmo. Houve épocas em que ao se votar num partido votava-se numa política; hoje a variedade é mínima, e se resumem quase sempre numa boa administração da coisa pública, que pode ou não cair no gosto de todos ou, pelo menos, da maioria. Enquanto isso há uma tirania da maioria sobre a minoria que pouco vem sendo debatida ou, pior ainda, percebida: as maiorias e as minorias não são estáveis, elas se formam e se desfazem em momentos políticos distintos. Exatamente por essa característica instável, se negligencia esse fato político, e muitos acreditam que a maioria e a minoria existam de antemão e de forma inalterável para sempre, como uma massa sólida, opaca e imutável, tratando a maioria e a minoria como entes substanciais, quando são ocorrências extemporâneas e inusitadas, que se formam no calor do momento. Saliento o fato que a obediência massiva das maiorias é sempre uma forma de mandamento e impõe comportamentos às minorias sem prestígio social ou força institucional.

Nas últimas décadas, sobretudo desde o fim da II Guerra, a Democracia se constituiu na única forma de governo passível de justificação. Todos os demais regimes políticos estão tipificados como autoritários, tirânicos, despóticos, totalitários e demais termos com uma conotação meramente negativa. Mas, a democracia funciona e sobrevive sob a oligarquia de políticos e burocratas profissionais, e com a ação política individual reduzida a uma participação por vezes meramente formal em eventuais eleições. Em todas as democracias ocidentais existe uma relutância em colocar em risco o equilíbrio dos interesses razoavelmente acomodados. Não existem grandes partidos ou grupos de pressão verdadeiramente radicais. O desejo de não perturbar o equilíbrio, por incômodo que seja, é 
avassalador. A tranqüilidade política e o consenso tornaram-se, aparentemente, o objetivo maior da democracia contemporânea.

O "governo do povo, pelo povo e para o povo" finda como uma ideologia. O povo só precisa escolher num pleito, que não deixa de ser uma forma de controle popular, mas que nem sempre ou raramente decide apropriadamente. As iniciativas populares nas decisões políticas podem se mostrar desastrosas quando não estão canalizadas pelos filtros dos partidos políticos e demais instituições políticas como Movimentos Sociais, ONGs etc. Há hoje um componente maior de governo e menor de popular nas democracias, e por essa razão a "apatia" 38 política transforma-se num bem político que freia as tentativas bruscas de mudanças e ameniza a ignorância política subjacente a grande maioria. O elemento característico da democracia contemporânea é a formação de uma elite política, na luta por disputar os votos do eleitorado em sua maior parte passivo, devido à maior complexidade da moderna atividade governamental que exige competências que a grande maioria se considera incapaz de possuir e preferem delegar a pessoas que aparentam saber o que é necessário fazer para haver a justiça e o certo.

Verdade que a democracia contemporânea é inspirada por um objetivo ambicioso: a educação de todos até o ponto que atinjam o pleno desenvolvimento das capacidades intelectuais, emocionais e morais, e possam se reunir de forma ativa e livre, em uma verdadeira comunidade ${ }^{39}$. Que todos os Estados sob governos democráticos atinjam maior nível de renda e com expansão constante da mesma; possuam alta porcentagem de indivíduos detentores de grau universitário e indicadores de bem-estar geral, tais como alta expectativa de vida e baixos índices de mortalidade infantil. Também é verdade que nunca houve guerra entre Estados democráticos. Isso tudo não deixa de ser um alento. E que o voto, longe de ser um mero procedimento formal (como o sorteio), é a expressão da

\footnotetext{
38. Nesse contexto, pode-se considerar uma das "virtudes" políticas mais importantes e atuantes nas democracias modernas a apatia, muitas vezes imprescindível para barrar movimentos extremistas que atraem as pessoas descontentes, desenraizadas, com fracassos pessoais, as socialmente isoladas, as economicamente inseguras, aquelas sem instrução, as intelectualmente simples e as autoritárias de todos os níveis sociais, que são muitos. A apatia política resulta num sinal de tolerância e de compreensão da diversidade, e tem o benéfico efeito na vida política de ser uma força de oposição relativamente eficiente contra os fanáticos de todos os matizes, que são aqueles que constituem o verdadeiro perigo para uma democracia. Isso não significa, de forma alguma, que a apatia seja desejável ou que não seja um mal político contemporâneo e que não se deva atuar para sua redução. Aliás, um dos objetivos desse trabalho é salientar o problema da alienação política. Apenas, não é indiferente que ela assuma em certos momentos políticos uma função política relevante. Constatar a presença é muito diferente de aprová-la ou concordar com a mesma.

${ }^{39}$. Na próxima parte se perceberá que essa educação forma um ser social, porém, não um ser político.
} 
igualdade e da liberdade de cada um: somos livres e decidimos nosso destino político; somos iguais e nenhum voto vale mais que outro.

Porém, deve-se ficar mais atento e um pouco preocupado quando todos concordam que a democracia é a melhor forma de governo, a mais conhecida e a melhor que se possa imaginar. Muitos dos princípios que justificam a democracia, na prática, não estão funcionando, e poucos se dão conta disso. A unanimidade em torno dela pode estar se tornando anti-democrática, na medida em que se rejeita de antemão qualquer coisa que não se apresente como democrática, inviabilizando talvez o surgimento de outras possibilidades políticas. A unanimidade sobre a democracia tem gerado a falsa percepção que ela é a solução de todos os problemas, quando ela só é operacional e conveniente com a participação de cada um para defender seus interesses ou colocar freios aos interesses prejudiciais dos outros. Com certeza, a democracia não é a solução dos problemas, é no máximo uma das formas possíveis de se resolver os problemas sociais sem ser prejudicado pelos problemas políticos ou econô micos: há espaço para o indivíduo e os diversos grupos sociais se manifestarem e buscar um acordo de cavalheiros. Mas, nada garante que isso venha a ocorrer, pois que a democracia só sobrevive onde existem democratas, e não depende apenas de leis ou de eleições para a sua efetivação, mas também do mútuo respeito e confiança, sem a obrigatoriedade da concordância ou até da aprovação, assim como da participação de cada um. Não obstante, o que de pior vem ocorrendo, é a perda significativa de entusiasmo por assembléias, debates e reuniões políticas, uma diminuição constante e preocupante de investimento na vida pública, deixando cada um de nós a maior parte (quando não a totalidade) da vida reservada às atividades meramente privadas.

Por outro lado, as ocorrências políticas e sociais estão sendo legitimadas mais facilmente. Não se está mais impedindo ou cobrando legitimidade de atitudes, ações e instituições que até pouco tempo atrás deveria ter uma suposta autoridade sancionando sua existência. O público, através dos seus debates que ocorrem em muito mais instâncias do que da política formal, se auto-institui sem que precise passar por qualquer legitimação oficial, ou unitária, ou unânime: desde que a ocorrência não impeça o agir do outro, não há impedimentos para elas onde a lei nada institui. No vácuo social do Estado e dos governos as pessoas instituem suas legitimidades. Não estamos mais livres, pois a liberdade não é algo quantificável, é algo que se exerce ou não, mas estamos menos presos a antigas 
formalidades para promulgação de uma ação pública, portanto, política. O campo de ação individual cresceu enormemente, acompanhando uma escalada crescente de tolerância da humanidade, ou pelo menos de parte cada vez mais extensa dela.

Se até meados do século passado quase toda legitimidade política advinha do Estado que criava e instituía seus organismos sociais e políticos, avalizando as iniciativas ou proibindo-as, agora temos um outro caminho que não é de cima para baixo, nem de baixo para cima, mas de vontades e interesses que se organizam até mesmo distantes das designadas criações populares. Pessoas, ONGs e movimentos sociais se legitimam pelos atos, resultados ou pela vontade instituinte de seus membros, quando adquirem visibilidade pública. Assim, paradoxalmente, é também perceptível que o voluntarismo, a participação individual nas causas públicas e humanitárias está crescendo em nosso tempo, e a legitimidade dessas ações políticas e sociais se dá não numa idéia jurídica ou institucional, mas pelo benefício difundido pelos resultados sociais, públicos ou humanitários obtidos.

Como alerta Ortega y Gasset no seu A Rebelião das Massas, o discurso político ignora o fenômeno contemporâneo da mundialização, que a multidão tornourse visível, e instalou-se nos lugares preferentes da sociedade. O conceito de multidão é quantitativo e visual. É o conjunto de pessoas não especialmente qualificadas. É o homem médio. É qualidade comum, é o mostrengo social, é o homem enquanto não se diferencia de outros homens. E, mais ainda, vivemos em tempo de nivelações: nivelam-se as fortunas, nivela-se a cultura entre as diferentes classes sociais, nivelam-se os sexos, também se nivelam os continentes.

A vida globalizou-se efetivamente; o conteúdo da vida do homem de tipo médio é hoje presente em todo planeta; e cada indivíduo vive habitualmente todo o mundo. Cada pedaço da Terra não está mais recluso em seu lugar geométrico, mas para muitos efeitos vitais atuam nos demais pontos do planeta. Podemos estar em mais lugares que antes, gozar de mais idas e mais vindas, consumir em menos tempo vital mais tempo cósmico. Mas, em definitivo, o crescimento substantivo do mundo não consiste em suas maiores dimensões, mas em que inclua mais coisas. E a vida do homem médio é hoje mais fácil, cômoda e segura que a do mais poderoso em outro tempo ${ }^{40}$. Que lhe importa não ser mais rico que

40. Tal afirmação pode ser questionada, por um lado, por idealizar a vida dos poderosos como sendo algo
sublime, invejável e ma jestosa, por outro lado, por desconsiderar as conquistas no campo das ciências e dos
direitos que a humanidade vem adquirindo nos últimos 150 anos, que aumentou a vida de um miserável 
outros, se o mundo o é e lhe proporciona magníficas estradas de rodagem, de ferro, aviões, hotéis, segurança física, Internet e aspirina ${ }^{41}$ ?

O mundo que rodeia o homem contemporâneo não o move a limitar-se em nenhum sentido, não lhe apresenta veto nem contenção alguma, mas, pelo contrário, fustiga seus apetites, que, em princípio podem crescer indefinidamente. Portanto, não se pode desprezar o fenômeno contemporâneo de uma massa de população, cada vez maior, que vem se incorporando à sociedade de consumo, dispondo não apenas de dinheiro, mas também de lazer, de tempo para devotar à cultura, sendo cada vez mais liberada do fardo extenuante do trabalho físico ${ }^{42}$. E nem tanto porque as pessoas são melhores remuneradas, mas porque os objetos culturais se tornam cada vez mais acessíveis e baratos. Isso não acarreta necessariamente que se deva concordar ou enaltecer essa massificação. Essa cultura de massa é produto e produtor desse homem de massa, fenômeno internacional, que cria uma cultura internacional, fenômeno senão ausente do passado, pouco saliente. Ainda que possam caber julgamentos sobre esse fenômeno, cabe antes procurar entendê-lo.

A despeito da acentuada adaptabilidade à sociedade de grandes setores sociais antigamente ignorados, o mesmo ocorre sem que tenham padrões culturais que permitam um refinamento na sua capacidade de consumo, demonstrando inaptidão para julgar ou mesmo distinguir as diversas produções e processos culturais, sociais ou políticos. Como diz Ortega y Gasset, esse homem-massa é um tipo de homem que não quer dar razões nem quer ter razão, mas que simplesmente se mostra resolvido a impor suas opiniões. O homem médio encontra-se com "idéias" dentro de si, mas carece da função de idear. Quer opinar, mas não quer aceitar as condições e supostos de todo opinar. Suprime-se todos os trâmites normais e se vai diretamente à imposição do que se deseja.

Entretanto, a cultura de massa, considerada como um fenômeno econômico mais que cultural, que parece servir apenas aos interesses de uma suposta indústria cultural niveladora e alienante, que visa tão somente a formação de um homem médio massificado e

contemporâneo para mais de 60 anos, enquanto mesmo a nobreza tinha média de vida de 40 anos a 300 anos atrás!

41. Verdade que continua havendo pessoas sem dinheiro ou sem recursos para desfrutar muitas das benesses contemporâneas, mas mesmo essas diminuem significativamente em números absolutos há 150 anos, se compararmos com aquelas que podiam desfrutar das estradas ou dos hotéis 200 anos atrás! Um operário alemão há 100 anos poderia desfrutar de uma viagem para a Tailândia como hoje realiza?

42. A quantidade de horas trabalhadas vem diminuindo significativamente em quase todo mundo, assim como aquisição de férias remuneradas, de dias de descanso semanais, direito a horas de lazer, flexibilidade nas horas de trabalho etc. 
criação de hábitos de consumo cultural, mesmo sendo um fenômeno da globalização ou do "imperialismo"43 que aparentemente busca impor padrões culturais internacionais, e que supostamente acabam com as nacionalidades ou regionalidades culturais, é das manifestações culturais, sem dúvida, a mais democrática e universal. Naturalmente, essa valorização, ou melhor, desvalorização desse fenômeno cultural, antes que ampliar o entendimento sobre esse fenômeno, afasta da razoabilidade e leva a tomar partido contrário, ainda que pela dimensão do mesmo, pela peculiaridade e pela sua abrangência, seja de longe o fenômeno cultural mais importante da modernidade, não pelo "alto" valor cultural que se produz (se é que é possível fazer essa aferição dos fenômenos culturais), mas por ser algo que envolve a humanidade para além de suas nacio nalidades.

A depreciação do fenômeno político da cultura de massa, estudada como um mero fenômeno econômico, esconde a incompreensão da ocorrência de um gosto que transcende preferências locais, que coloca em xeque estruturas explicativas cativas da academia, que julga antes de entender, que acredita que os afetos legítimos são decorrentes apenas dos laços face a face, e não se dá conta que se formam valores e gostos para além da intimidade do imediato e dos estreitos laços familiares, regionais ou naciona is. O fato é que gosto e valores são formados sem os controles das autoridades acadêmicas e políticas regionais, e isso assusta aos intelectuais e governantes, pois escapa ao seu controle de qualidade ou, pior ainda, ao seu poder explicativo, ou o seu direcionamento no sentido de seus interesses.

A negligência da política contemporânea, ainda fortemente arraigada em problemas nacionais, com as questões que transcendem fronteiras físicas e geopolíticas leva a manutenção de estruturas sociais arcaicas, que subsiste tão somente pela inércia de sua existência consolidada. O nacionalismo, até o momento, conspira contra o civismo e o humanismo, levando a ter como foco apenas problemas locais, esquecendo-se ou relegando questões humanitárias para um plano secundário da preocupação nacional. Raros são os partidos que defendem causas internacionais: preferem restringir as massas nacionais aos interesses miúdos locais, quando as massas humanas hoje se ramificam mundo afora, e há inúmeras causas que interessam a humanidade enquanto um todo e que carecem de representação política no palco do poder nacional e internacional. Foi adquirida uma cidadania internacional que não resplandeceu ainda em algum tipo de representação política

\footnotetext{
${ }^{43}$. As aspas ficarão justificadas na terceira parte onde será abordado o mito do Império.
} 
nos partidos políticos convencionais, e até o momento é apenas um tema de debate de pensadores da política, e com poucos indivíduos conscientes de sua existência e dispostos a exercê-la efetivamente.

Todavia, hoje temos recursos de comunicação que nos permitem falar com todos ao mesmo tempo e nos mais diversos lugares. Pode-se exercer pressão na opinião pública assim como sobre as autoridades constituídas, panfletar o mundo com idéias políticas, burlando as mais rigorosas formas de censura. Os encontros não necessitam mais ser apenas fisicamente; podem ocorrer de forma virtual, podem ser convocados por e-mails, por sítios, por pessoas que adquirem alguma notoriedade pelo inusitado que faz, pensa, mostra ou diz. Não há limites que impeçam uma pessoa, numa democracia ocidental, de manifestar suas posições, de assumi-las publicamente, de lutar e defender seus interesses, de convocar aliados para sua causa, de formar partidos ou instituições que possam interceder no mundo para a defesa de seus interesses privados.

O problema é porque poucos se dão ao trabalho de se posicionar, porque a grande maioria se abstém de manifestar-se politicamente e delegam deveres e responsabilidades para outros. Sim, substancialmente cresceram as formas e as possibilidades de se expressar politicamente nas últimas décadas, porém, diminuindo estrondosamente a necessidade de se manifestar politicamente. A política está perdendo o interesse do homem médio? Ou as mudanças políticas estão ocorrendo e nossa sensibilidade não está captando as mudanças profundas que podem estar transitando sem revoluções e revoltas massivas, mas por aquisição de mentalidades através de processos históricos, antes que por mudanças bruscas e revolucionárias? Direitos das mulheres, das crianças e humanos estão sendo exercidos por maiores números de pessoas e Estados pelo mundo através de uma mentalidade alargada do entendimento do que é politicamente certo e justo, nem tanto por marchas ou passeatas, o que, é claro, nunca tira a necessidade das mesmas em certas circunstâncias como um exercício legítimo de manifestação de uma posição política compartilhada.

O que importa é salientar que um discurso pode criar um público, que a ação individual pode ser agregativa e tornar-se um movimento político. Não existem impedimentos de ordem política ou moral. Mas, quem tem um discurso capaz de alterar os destinos como estão condicionados ou de sensibilizar os demais sobre eventos que deveriam ser realizados? Quem tem coragem de lutar por si e pelos demais sem ambicionar 
a força do Estado? Quem quer responsabilidade pública sem o privilégio daqueles que são empregados para essas atividades? Quem, de fato, quer o trabalho e o esforço da vida republicana e democrática, que exige de todos paciência, participação, dedicação, abnegação, deveres e obrigações? Encantados com os direitos conquistados nos últimos 150 anos, nos esquecemos de educar para os prazeres que advêm do cumprimento dos deveres, e eles existem, e servem até mesmo aos egoístas, desde que razoáveis.

Por fim, salientemos que uma igualdade vem se construindo nos dois últimos séculos: a maior parte da população ocidental é educada em letras e números, e com esses instrumentos tem acesso a tudo que é feito pelo homem. Naturalmente, é preciso vontade, determinação e talvez um pouco de coragem, mas todos estão igualmente aptos a desvendar os mistérios do mundo, ter acesso às informações coletadas pela humanidade, construir o próprio caminho, criar um lugar no mundo e desfrutar da vida com os demais, ao ter domínio das palavras e saber fazer contas.

Nem todos conseguirão. Muitos têm problemas de saúde física e/ou mental. Há muitos preguiçosos e covardes. Há os irresolutos, os confusos, aqueles que não têm paciência e aqueles que não sabem esperar. Há muitos vaidosos e arrogantes. Sempre há os fúteis e os medíocres. Enfim, somos muitos e só os mais hábeis vencerão. Não porque deve haver derrotados para que haja vitoriosos, mas porque há pessoas que perdem mesmo que ninguém ganhe com sua derrota, quando não leva ainda muitos outros consigo em sua degeneração. Não se percebe uma coisa simples, que a luta é interna, na tentativa infindável de romper com a ignorância e aprofundar uma sensibilidade mais apurada. A verdade é que se precisa consertar primeiro a si mesmo, antes de querer consertar o mundo. 


\section{Parte 2: Um Ideal de República ${ }^{44}$}

Aquilo que a todos afeta, por todos deve ser aprovado

Justiniano

República denota um Estado governado por representantes dos cidadãos, ao passo que um Estado governado pelos próprios cidadãos seria uma democracia.

James Madison.

\footnotetext{
44. A noção de República aqui utilizada tem dívidas com muitos pensadores, de onde foi retirada a síntese que serviu de fio condutor da reflexão sobre o público e privado. Em particular deve-se salientar o livro $A$ Condição Humana de Hannah Arendt, A República de Renato Janine Ribeiro, Origens do Republicanismo Moderno de Newton Bignotto, Pensar a República Org.: Newton Bignotto, Comunidade e Democracia: a experiência da Itália Moderna de Robert Putnam e Em Busca Del Humanismo Cívico Florentino : ensayos sobre el cambio del pensamiento Medieval Moderno de Hans Baron. Naturalmente nenhum deles deve ser responsabilizado pelas questões aqui colocadas, muito menos são obrigados a concordar com as mesmas.
} 
A palavra República carrega, além de uma denotação, várias conotações. Sua existência concreta e a sua imagem em cada época e lugar são ocorrências recorrentes na história do pensamento político ocidental, estando sempre acompanhada de elogios e dignidade, apesar de ter inúmeros críticos, e haver dificuldade para distinguir o que de fato foi realizado do que foi idealizado pelos seus defensores e críticos. De fato, sua efetividade prática é questionável, tanto no passado como no presente e, por mais que não se queira, acabamos falando de alguma coisa ideal ${ }^{45}$ quando se discorre sobre a República. Como qualquer fenômeno político, as barreiras entre o ser e o dever ser são frágeis, quando existem, afinal de contas, a política é uma ação presente mas com vista a algum tipo de futuro, apesar de ser mais tratada como uma reação ou conflito de partes da sociedade contra outras partes ${ }^{46}$.

Longe da pretensão de buscar a origem da República como fenômeno político, onde pode se incorrer no equívoco de achar que há uma essência ou uma base ontológica que vem se desenvolvendo através dos tempos, cujo ápice seriam as Repúblicas atuais, deve-se salientar que existiram e existem diversos tipos de Repúblicas, tantas quantas são as sociedades. É pouco provável que haja algo que seja comum a todas, a não ser se forçar semelhanças e esconder as diferenças. Desde a sua primeira fundação na Roma Antiga até os dias atuais a República vem sendo resignificada. Tentar encontrar um núcleo duro e comum que possa identificar essa instituição da Antigüidade até os dias atuais, de tal modo que o termo se refira a algo palpável, a uma essência, ou a um princípio inalterado que se mantém firme pelos séculos que nos separam da sua primeira criação, parece uma tarefa impossível ou inócua, e corre-se o risco de simplificar a história ou forjá-la, "pecados" pesados demais para a atividade acadêmica, e pior ainda para a atividade política.

Se há algo que a história revela é que as instituições se transformam, e tentar buscar o que se mantém inalterado nelas, muitas vezes obscurece aquilo que vem se diferenciando de forma mais sutil, através de opções sociais variadas no decorrer do tempo. O grande problema é, como abordar algo que não tem uma substância inalterada como possuem os

\footnotetext{
45. A começar por Platão cuja República inaugura a delimitação entre o público e o privado, e a necessidade de um Estado ser regido por leis e princípios, assim como por homens justos. Os republicanos costumam defender as virtudes que o regime permite, onde o cidadão pode se desenvolver com a garantia da harmonia através de um Estado que efetiva a vontade da sociedade. Mas onde de fato isso acontece ou aconteceu? Pode isso acontecer?

46. Ora, os conflitos sociais devem ser resolvidos na política, ou devem ser resolvidos os problemas sociais para que todos possam participar da política e seja útil a todos?
} 
seres naturais, mas uma função que se altera a cada momento que se realiza, com um discurso e uma linguagem que desconhece uma autoridade unânime sobre sua terminologia, e não se reduz à linguagem matemática, nem à precisão de processos descritivos que as ciências naturais conseguem com tanto êxito?

Nesse sentido, a opção aqui será salientar o lado fundacional do fenômeno republicano, a idéia subjacente de algo construído, fundado, instituído, um ideal que se efetiva e se desfaz na história, algo que não existe anteriormente a sua criação, enquanto buscar a "origem" parece que se está buscando decorrências de um produto natural (não cultural), como as origens das espécies, a origem do universo, que foi evoluindo por leis imutáveis: as leis humanas, invariavelmente, estão sujeitas à criatividade dos seus membros. Ou seja, há necessidade da vontade instituinte de uma sociedade civil para se constituir uma Republica.

Enquanto uma Nação é um dado anterior a qualquer ato político ou legislativo, sendo feita de indivíduos livres, iguais, independentes, diferentes uns dos outros, mas unidos por necessidades comuns e pela vontade de viverem em conjunto, uma República se institui quando esse contato íntimo e profundo dos indivíduos de uma nação se transforma num contrato com obrigatoriedade de lei para pessoas que não têm intimidade, mas que necessitam da confiança mútua: a República é uma reunião de homens associados por um reconhecimento comum do direito e por uma comunidade de interesses particulares.

Certo é que a República ${ }^{47}$ é conhecida como uma forma de organizar pessoas, de modo que os interesses privados podem ser tratados publicamente na praça, negociados, entre pessoas que são iguais em direito, expondo e trocando interesses em público. A República garante a praça a todos e permite a fala como meio de criar relações interpessoais, a vida política e/ou pública, obtendo-se formas de trocar, conjugar, conciliar, resolver, julgar, debater, decidir e comungar interesses distintos, todos eles gerados na privacidade dos interesses particulares e íntimos, sem intromissão de uma força coercitiva e despótica, senão seguindo tão somente aos interesses próprios. Isso não significa que sempre se obtenha sucesso nessa empreitada; pelo contrário, há muitos fracassos entre

\footnotetext{
${ }^{47}$. Monarquia e República por vezes parecem ser uma contradição, entretanto, o fato é que não se definem pelo mesmo critério. Monarquia se define por quem manda: significa o poder (arquia) de um (mono) só. Já a palavra República não indica quem manda, e sim para que manda: o poder está a serviço do bem comum, da coisa coletiva ou pública.
} 
poucos sucessos. Não há fatalidades, mas há os imprevistos e, principalmente, os equívocos.

Um Estado Republicano é administrado por leis e princípios estabelecidos entre pessoas iguais, num Senado, numa Câmara, num Parlamento, mas também na praça, nas ruas, na imprensa, enfim, na opinião pública, comercializados entre interesses privados colocados em público, onde cada um é responsável por si e pelos seus, e por todos quando a República corre perigo, seja de agressões externas, seja de internas. No Estado Republicano cada um faz a sua parte, pois é livre e senhor de si próprio, e vai à praça negociar afetos, interesses, desejos, promessas, objetos, comida, ações em comum, vontades coletivas, justiça e, necessariamente, preservar os desejos particulares e íntimos, ou entar frear interesses que sobrepujam ou colocam em risco os próprios.

É na República que a participação política pode ser entendida na sua plenitude, pois só nela a participação de todos os cidadãos é exigida como uma condição sine qua non para o seu funcionamento. Nela todos participam, conscientes ou não dessa participação, e o nível e a qualidade de participação dos cidadãos é que determina o sucesso ou insucesso da vida republicana, e, paralelamente, a qualidade da atividade governamental. Via de regra, é muito comum se confundir o Estado com o governo, sem notar que são instâncias distintas da participação política, e no mais das vezes se acredita, mais ainda, se defende, que é preciso mudar os governos para que ocorram mudanças no Estado ou na sociedade.

O público, portanto, é aquilo que está afeito e dentro do âmbito da comunidade cívica dos cidadãos, o que é comum, que expande e potencializa as particularidades numa totalidade maior, podendo ser uma cidade, um Estado, uma nação ou um país. É mais do que a soma das individualidades, pois daí se teria apenas uma multidão ou uma extensão territorial: não é uma mera soma aritmética, mas uma fusão que resulta em poder moral e cultural, que forma uma identidade nacional. Mas, esse público só existe quando se institui a República e as pessoas adquirem a cidadania. Isso acarreta que se assume a responsabilidade coletiva pelas decisões que afetam a coletividade, deixando de ser um monopólio do governante. O Estado recebe as incumbências delegadas pela sociedade civil que compartilha o ônus da sua manutenção, do seu desenvolvimento e destino. Portanto, se constitui duas esferas de atuação distintas, ainda que complementares, ficando parte dos deveres na mão do Estado e parte na mão das pessoas privadas da sociedade civil. 
Aqui observamos uma primeira contraposição, aquela existente entre o privado e o estatal; há coisas administradas por particulares e há coisas administradas pelo Estado, que muitas vezes podem entrar em confronto. O quê, o como, a quantidade e a intensidade da esfera dessas atuações dependem da capacidade política da sociedade; quanto mais forte e estruturada a sociedade civil, menor a necessidade e a atuação do Estado e mais limitada sua coação sobre o cidadão. O indivíduo pertence a si mesmo e só está submetido a um controle social com o propósito de impedir dano aos demais. O homem é soberano sobre si mesmo e a sociedade é soberana sobre os atos que afetam aos outros indivíduos. Porém, indivíduo e Estado são dois órgãos de um único sujeito - a República. E o que se discute é se certas necessidades sociais são mais bem atendidas ou servidas por um ou outro órgão: tudo o que não toque as necessidades da própria sociedade civil deve ser deixado a livre determinação do cidadão.

República assim se refere a uma ordenação jurídica que tem por base a possibilidade de participação dos cidadãos nos negócios da cidade e à estabilidade das regras que regem a participação. República é fundamentalmente um "regime constitucional", onde as leis e regulações ordinárias, bem como as disposições do governo, derivam de princípios conferidos, em sua forma, pela sociedade, e onde as instituições públicas, postas acima de todos, a protegem de todo interesse particular ou transitório, de toda vontade caprichosa ou arbitrária.

O termo República nos remete à idéia de "governo das leis" (e não de homens), de império da lei e mesmo de estado de direito, e nos remete também à prescrição de que os que mandam também obedecem. A mera postulação de uma esfera de interesses comuns assinaladas acima não é suficiente para determinar ordinariamente uma República: a questão da participação política, da implicação efetiva de todos na expressão e realização do bem comum é o que torna o regime republicano, pois não propõe apenas que o poder seja contido por leis e se exerça para o povo, em vista do bem comum, mas exige ainda que seja exercido, de algum modo, por todo o povo. É republicano o regime que não somente visa o bem comum - por quaisquer meios que sejam, inclusive os autoritá rios - mas também escolhe, nessa direção, meios republicanos, que estão ligados à igualdade, à liberdade, à fraternidade: a moderação e a contenção dos desejos e interesses privados (há uma espécie de chamamento ao desinteresse de si) em vista do amor pela cidade, e a 
abnegação, em função do empenho na promoção do bem público constituem as chamadas virtudes cívicas.

Numa República os cidadãos não têm outro senhor além da lei: e essa tem como função garantir a liberdade de todos e realizar a justiça, punindo o criminoso na proporção do seu crime, devolvendo a cada um o que lhe foi ilegalmente subtraído, distribuindo a cada cidadão "o igual pelo igual" (isonomia) e o "desigual pelo desigual” (a recompensa em função dos méritos). A lei não é nem uma construção artificial, nem um dado da pura razão: é a expressão política da ordem republicana, levando em conta a situação da cidade e de sua história, assim como a composição do corpo social.

Naturalmente, as Repúblicas não pensam o povo como livre para produzir suas leis - aquelas que bem entender, como se nada lhe fosse impossível ou interdito - pensam o povo como livre por seu amor às leis, por seu consentimento e adesão às formas institucionais determinadas pelo consenso possível dos interesses, formuladas pelo legislador. Mas, o povo apenas delega seu poder aos governantes, sem jamais aliená-lo. Logo, o estatuto de um governante republicano jamais pode ser o de um soberano absoluto, mas somente o de um ministro ou funcionário da República. A autoridade última deve permanecer em todos os tempos nas mãos do próprio povo, que sempre pode controlar ou mesmo destituir seus governantes se estes cessarem de agir em conformidade com os poderes estritamente limitados que lhes foram confiados. Nenhuma ação pode ser iniciada sequer pelos mais altos entre os magistrados, se anteriormente não tiveram recebido autoridade para isso do povo.

A verdadeira República somente está completa quando todas as partes, como membros de um único corpo, se encontram bem atadas em perfeita unidade, cada qual praticando seu ofício e dever de tal modo que, seja qual for a condição, ofício ou grau de cada um, esse possa cumprir seus deveres com diligência e empenho, e isso sem ter inveja ou ameaça de outrem, assim como desfrutando dos direitos. Portanto, em cada República a autoridade política fundamental não é o governo ou a parte governante, senão o legislador humano, que é o povo, todo o corpo de cidadãos. O único soberano legítimo é o povo, que deve distinguir-se do governo, e subordinar todos, inclusive o poder legislativo que deve estar, por inteiro, na mão de todo o corpo de cidadãos; o governo administra com estrito apego às leis e, caso transgrida uma norma, o mesmo será repreendido por toda cidadania. 
O pressuposto é que o homem comum do povo é competente para fazer leis e para eleger governantes ou magistrados, assim como para destituílos.

Assim, um Estado se torna republicano quando está sob domínio da sociedade civil e cumpre uma função pública. Caso contrário, atividades e bens estatais servem tão somente aos próprios interesses estatais do ocupante do governo, em contraposição à sociedade civil organizada (uma minoria) ou desorganizada (a grande maioria). Como não pode atender a necessidade de todos, o governo distribui - do Estado que não é público, ou como a tradição nos ensinou a chamar, republicano - esmolas entre os pobres e privilégios entre os mais fortes e astutos, aliando-se a setores sociais para a dominância sobre os demais setores sociais, que estarão conjugados pela coerção da força estatal para direcionar os interesses comuns, de forma a beneficiarem aos interesses particulares dos governantes e seus associados. Acreditam, é verdade, que é para o bem de todos, que sabem exatamente conjugar da melhor forma o interesse comum.

Não obstante, a idéia fundamental de uma República é que tudo tem uma função social, o que oscila é se as coisas estão administradas por um particular ou pelo Estado, mas tudo deve cumprir uma função pública e ao público se dirige. O privado pertence à esfera pública e só pode ser exercido como uma concessão da sociedade civil aos seus cidadãos e às suas instituições. É só nos Estados despóticos que se espera que o governante resolva todos os problemas sociais e administre pessoas segundo interesses supostamente comuns estabelecidos pelo forjado calor das $\operatorname{urnas}^{48}$, pela tradição de alguma família real, por tiranos ou teocratas, ou ainda por costumes rígidos e grosseiros. Isso é uma das coisas que caracteriza uma República. Os bens sociais, sejam particulares, sejam estatais, estão obrigados a cumprir sua função pública ou as pessoas correm o risco de serem destituídas de seus direitos de exercerem as funções, sejam as estatais, sejam as particulares.

Entretanto, o público se confunde com o estatal, estando quase como sinônimos, pelo menos em grande parte da literatura nacional e latino-americana. Isso se avista nos jornais, nos panfletos, em livros, em textos acadêmicos. O Estado, via de regra, é encarado como único organismo público de fato e de direito. Então, cria-se a grande polêmica, na verdade uma querela, entre o público e o privado, entendido como dois interesses opostos ou contraditórios. Porém, o privado não se contrapõe ao público, pelo contrário, desde que

\footnotetext{
${ }^{48}$. Lembremos do não saudoso Saddan Houssein que nunca perdeu uma eleição.
} 
se constitua a res publica, o privado adquire (ou deve adquirir) uma função social relevante (além de permitir o bem particular, é claro), e tem a função de possibilitar o desenvolvimento social ou público, ou seja, visa o bem comum: não há necessariamente conflito entre os interesses particulares e os interesses públicos, e o desenvolvimento dos cidadãos particulares é também o desenvolvimento da República. O valor ético dos interesses depende apenas do uso que se faça dos instrumentos para obtê-lo ${ }^{49}$.

Portanto, numa República, o que se contrapõe ao privado é o estatal, e o que se contrapõe ao público é o clandestino. Não posso fazer da minha casa um prostíbulo, pois na minha zona residencial esse tipo de atividade privada é proibida, em função do interesse comum em ter uma área meramente residencial. Também não posso fazer da minha casa uma pocilga, pois novamente se trata de uma região residencial, assim como também não posso fazer uma indústria asfáltica ou outra atividade poluente. O Estado não pode ter atividades de prender, torturar ou matar os cidadãos, nem governantes podem desviar recursos públicos para seus objetivos particulares (a não ser, é claro, que tudo se faça de forma clandestina).

Numa República o privado tem uma função pública, atendendo não apenas as necessidades individuais do proprietário, mas igualmente a coletividade que lhe garante a privacidade e dela cria a dependência para aumentar ou manter seus bens. O comércio, o sistema financeiro, as terras, as residências, a indústria, a educação, a saúde, as instituições de segurança e justiça, enfim, tudo tem uma função e atuação pública e está submetido ao

\footnotetext{
49. Hans Baron no seu livro Em Busca Del Humanismo Cícivo Florentino : ensayos sobre el cambio del pensamiento Medieval Moderno é muito elucidativo sobre essa questão ao nos colocar diante do pensamento dos primeiros republicanos modernos: "As riquezas verdadeiramente consideráveis provem dos ganhos obtidos mediante o comércio, atividade que, no fim das contas, é mercenária, e como considera muitas pessoas, não de todo honesta. Sua resposta é que, pese o todo, a riqueza deve ser valorizada altamente, dado que um mercador rico resulta mais útil para República e ainda mais para sua família. A riqueza traz consigo, com freqüência, amizade, elogios e dignidades, que podem ser muito útil à pátria. Nem sempre é possível pagar, dispondo só dos fundos públicos, os salários daqueles que defendem a independência do país. Nem as Repúblicas podem incrementar sua glória e seu poderio sem recorrer a gastos enormes. Em conseqüência devem ser capazes de recorrer a boa vontade dos cidadãos ricos". (P. 235). E um pouco mais a frente complementa a idéia: "Há uma cena na obra de Xenofonte que o interlocutor principal, antes de abordar o tema do manejo de um fazer privado, é questionado por Sócrates sobre se deseja verdadeiramente converterse em um homem rico e levar uma vida de problemas. O personagem responde que existem três motivos pelos quais deseja ser rico: ser capaz de honrar aos deuses sem fixar custos, ajudar aos seus amigos em momentos de necessidade e ser capaz de encarregar-se de que a cidade não lhe falte adorno algum que o dinheiro possa comprar. Sócrates exclama: essas são aspirações nobres, verdadeiramente dignas de um homem de meios, $e$ aqueles que se arrolam para sustentar suas propriedade e que ainda sobre o suficiente para o ornato da cidade e auxiliar aos amigos podem ser considerados, de fato, homens grandes e poderosos". (P. 236). Tradução livre.
} 
cumprimento de seus deveres sociais. Ser proprietário numa República significa que a posse está limitada ao interesse público e privada da onipotência do proprietário ${ }^{50}$ ou do Estado. Como a propriedade privada tem função social, quando se utiliza em detrimento do público, adquire-se o direito de desapropriá-la. Logo, o que se opõe ao público são as atividades clandestinas, aquelas que se fazem em segredo, na calada da noite, sempre em detrimento do público, do privado e do estatal, e ainda, por vezes, dos três, quando se trata da corrupção ${ }^{51}$ nos organismos públicos. Dentro do republicanismo, o privado é aquilo que está afeito e encontra-se no âmbito da particularidade dos indivíduos, e, como salientado, de forma alguma exclui sua função pública, uma vez que as particularidades se entrecruzam na existência social e se imbricam na construção da sociedade. A propriedade privada não é um lugar onde se pode exercer um domínio ilimitado, mas o contorno de uma extensão sob o cuidado de particulares. Antes de ser uma ampliação da liberdade, é, sob inúmeros aspectos, uma limitação, uma privação ${ }^{52}$.

Não há uma mera defesa da propriedade privada como uma positividade absoluta, nem há necessidade de se debater se seria ou não justa a existência da propriedade privada, já que o objetivo de instaurar uma República é garantir o direito à propriedade como um bem comum, ou melhor, a privacidade, mesmo porque essa distinção entre público e privado aparece e decorre de uma visão política criada exatamente pelo regime republicano, que salienta o lado público que adquirem numa República, tanto as pessoas, como suas coisas particulares, como suas instituições. Aliás, se o público não der seu assentime nto à propriedade não se pode ser proprietário. Se o público não respeitar as autoridades as mesmas não exercem seu poder. Para ser proprietário dos bens é preciso que o conjunto da sociedade reconheça a posse particular da mesma, senão, basta um reles ladrão de quintal para ser furtado em qualquer coisa, assim como um governante só se mantém enquanto

\footnotetext{
50. O comércio, por exemplo, é uma atividade pública por excelência e igualmente encontra-se limitado aos interesses da coletividade e não apenas do proprietário do empreendimento: ele é obrigado a fornecer mercadorias de boa qualidade, que não estejam estragadas, caso contrário será punido pela sociedade; punido não apenas pela perda da freguesia, o que é uma decorrência comercial entre a oferta e a procura, mas pelas leis que protegem os direitos do consumidor, ressarcindo a pessoa prejudicada pela aquisição de uma mercadoria estragada.

51. A corrupção é um crime sui generis na medida em que a sua efetivação prejudica o próprio ator, e será abordada mais a frente como um tipo de violência da vida política contemporânea.

52. Sobre essa questão é interessante a leitura de A Condição Humana de Hannah Arendt, em particular o Cap. II - As esferas pública e privada.Nesse capítulo ela nos coloca diante dos problemas que acarretam a saída da vida privada para a entrada na vida pública.
} 
houver consentimento da sociedade. E isso porque a constituição da República torna tudo público, especialmente o privado e o Estado. Mais ainda, só na República ocorre a possibilidade de haver o privado, tanto que só nela há indenizações quando desapropriados os bens, e não podem os cidadãos ser presos arbitrariamente pelo Estado: no Estado Despótico não há propriedade privada propriamente dita, apenas posse como uma concessão do governante (não da sociedade civil!), mas que sempre se corre o risco de perdê-la, basta cair no seu desafeto, a começar pela própria vida. Fundamentalmente, uma República garante que os direitos, bens, vontades e desejos não precisam er exercidos clandestinamente, mas podem ser expressos em público, ainda que muitos desejos e vontades só possam ser realizados na privacidade do lar ou em lugares próprios, e algumas atividades estatais estejam obrigadas a ser sigilosas: há negócios de Estado que não podem ser comunicados publicamente a todo povo, sem pôr em risco o interesse comum.

Cada homem deve buscar sua felicidade e o seu prazer, porém, sem prejudicar ninguém, e para coadunar essa infinidade de indivíduos interesseiros, se utiliza dos instrumentos estatais para garantir a traficabilidade dos interesses privados na praça pública, assim como garantir e potencializar o conjunto de pessoas. O comércio, as relações interpessoais, os bens particulares, assim como os estatais tornam-se algo regulado pela sociedade, que subjuga tanto o Estado como os particulares, em função de interesses maiores: o bem comum. Não se pode vender produtos que não prestem sem receber reprovação ou punição da sociedade. Não se pode amar uma pessoa e tomá-la para si, pô-la sob seu arbítrio, sem que essa relação passe por uma regulação social qualquer, um contrato matrimonial, mesmo que não esteja registrado em cartório - basta o reconhecimento pela sociedade, do testemunho de amigos ou do público. Não se pode adquirir material radioativo e estocá-lo no quintal da casa, nem o Estado pode adquirir bens supérfluos e esbanjar os impostos arrecadados. Outra coisa muito diferente é se isso acaba ocorrendo de fato, e não apenas de direito, ou somente no mundo das idéias ras Repúblicas existentes. Parece que em algumas partes do mundo a República ocorre de forma menos "defeituosa".

A República como forma de Estado parece conseguir equilibrar e comportar as vantagens dos três regimes clássicos de governo, o monárquico, o aristocrático e o democrático, garantidos pelas disposições que têm como objetivo o respeito pelos interesses e direitos do povo. Conforme a detenção da soberania caiba a todo povo ou 
apenas a uma parte do mesmo, o regime republicano tem forma democrática, aristocrática ou ditatorial e/ou monárquica. No regime republicano o poder é detido pelo povo (sua natureza) e nele reina a virtude (seu princípio), entendida no sentido político (amor pela res publica), virtude constantemente solicitada, através de diversos meios (educação cívica, economia autárquica, impostos, convocações ordinárias e extraordinárias): sua sorte está condicionada por ela.

Todavia, a República contemporânea, cujo início pode ser datado na modernidade ${ }^{53}$, representa um tipo de racionalidade social que coaduna os interesses privados para os benefícios públicos, sendo mantenedora da ordem, da paz e da justiça, além de responsável pela manutenção dos direitos e da cobrança dos deveres. Sua função não é tanto desenvolver virtudes (como foi a República Romana ou a Democracia Ateniense), mas possibilitar a busca do interesse privado dos cidadãos, assegurando a primazia do bem comum, do público sobre o particular ou o privado, assim como sobre o Estado. Ao se descobrir novos desejos, em vez de deixar que eles perturbem o social, o Estado busca abrir canais para que o enriqueçam. E a função do Estado Republicano contemporâneo tem sido apenas regulamentar os desejos e vontades privadas para que saiam da clandestinidade, tornando-as públicas, e assim todos findem ganhando com os vícios e os prazeres íntimos, gerando benefícios públicos ${ }^{54}$, cobrando impostos ao invés de perseguir hábitos, que grupos majoritários promovem e querem impor às minorias ou a um único indivíduo.

Muitos fenômenos sociais como a bebid a, o jogo, a prostituição estão deixando de ser tratados como caso de polícia, no máximo, seu agravo é como um caso de saúde pública: fenômenos humanos estão sendo tratados sociocultural-economicamente como produto da vida civil e particular. Inverteurse a questão da moralidade social; a República contemporânea deixa de perseguir consumidores, os que desfrutam dos prazeres, e legislar sobre a individualidade, mas usa recursos advindos dos bons e dos péssimos hábitos individuais para a manutenção da ordem social. Quer cobre quer não, o Estado e a sociedade arcarão com gastos das pessoas que praticam vícios: não havendo como impedir que haja viciados, na medida em que vícios são frutos de escolhas individuais, é melhor

\footnotetext{
53. A referência é Skinner e seu As Fundações do Pensamento Político Moderno, Historia de la Filosofia Política, de Strauss e Cropsey e O Poder: história política moderna, de Giuseppe Duso.

54. Como bem nos alerta para esse fenômeno Mandeville no seu A Fábula das Abelhas: vícios privados, benefícios públicos.
} 
deixar se acabarem ou apenas desfrutarem (como parece ser o que mais ocorre) seus vícios e prazeres privados e cobrar impostos públicos, do que perseguir, gastando tanto na perseguição como no tratamento e na acomodação de pessoas voltadas para isso. "Que todos ganhem! Os viciados o seu prazer e o Estado os impostos!”, brada a República moderna, que apenas cobra pelos desfrutes pessoais, não mais os perseguindo, porque se entende que isso diz respeito aos interesses dos indivíduos, são coisas íntimas. Entretanto, devem arcar com altos impostos o custo social de sua prática particular, pois sua prática redunda em algum tipo de dano social. Ou seja, numa República moderna o Estado deve ser um lugar para congregar e interligar os diversos interesses sociais dispersos, quando possível, ou deixá-los em paz quando necessário, e manter a paz entre os interesses quando cada um está voltado só para si; só pode intervir quando a ação individual limita a ação de outros indivíduos.

Ora, muitos problemas sociais e políticos não vêm de se liberar as atividades individuais quando restrita aos indivíduos ou a privacidade das pessoas, mas de se restringilas ou perseguí-las. A restrição além de custar caro, é burlada, gerando violência: se há cura para uma suposta "anarquia" moral, essa não é o despotismo, mas antes a deliberação cooperativa. Parece difícil se chegar ao conhecimento sobre os homens sem alguma aceitação de algum tipo de "mal". Parece difícil haver um regime republicano que funcione sem a admissão de que algum mal necessariamente subsista, e de que o importante é limitalo, mais do que aboli-lo. Como diz Espinosa de forma muito apropriada: "Temos que construir o Estado não com as virtudes dos homens, que são escassas, mas com suas paixões, as quais devemos saber como canalizar na direção adequada”. Um Estado republicano procura mecanismos de controle e restrição para exercer influência e fazer todos, mesmo os supostos homens maus, ter interesse em agir pelo bem comum.

Com a República, a lei civil se transforma na restrição do direito de todo homem a toda coisa do estado de natureza. A atividade legislativa é essa restrição e a lei serve fundamentalmente para limitar a liberdade natural ${ }^{55}$ dos indivíduos e a ganância do Estado. Não é uma liberdade metafísica que interessa, mas a independência da sociedade civil, considerada como uma pessoa adulta e racional, portanto, capaz de se autogovernar através

\footnotetext{
55. Liberdade natural e estado de natureza são conceitos historicamente complexos. Por si só é assunto para uma longa tese. Entretanto, no meu caso, estou me apropriando da concepção vulgarizada de Hobbes.
} 
das atitudes individuais e coletivas de seus cidadãos: aprende a obedecer leis e normas, não por submissão, mas pelo respeito. E a lei é o veículo que permite a passagem do egoísmo privado para o bem comum, pela construção de instituições e instrumentos que permitem ao cidadão perceber que precisa respeitar as leis ou a moral, pois sabe que será punido, caso as descumpra. Isso cria um quadro de previsões, que permite antever os danos que sofrerá caso aja imoral ou ilegalmente e, assim, inverte a lógica imediatista do ganho fácil do egoísmo particular em perda certa de uma lógica cívica, freando o exercício do egoísmo mesquinho, ou pelo menos inibindo-o significativamente. A consciência da existência do simples poder coercitivo, da violência punitiva, atinge a maior parte das condutas desviantes, pois que foram determinadas com antecipação e as castiga com intervenções físicas - prisão, por exemplo - cujo valor é também preestabelecido e medido conforme a gravidade da desobediência. Isso significa tornar o crime um mau negócio e, ao mesmo tempo, proporcionar saídas para as tensões que se expressariam nele.

Esse tipo de consciência provoca na população um temor racional e permite o cálculo dos custos dos comportamentos da desobediência, criando uma noção de interesse bem considerado. Ora, embora egoístas, os seres humanos não são tão irracionais que não possam trocar o prazer imediato pelo de mais longo prazo, ou não possam fazer o interesse de outras pessoas sobrepujar o seu próprio, como forma de satisfazer desejos.

Ao incutir a virtude política, enquanto integradora que inclina os cidadãos para a eticidade pública, a República une os interesses conflitantes da sociedade. Ricos e pobres ao integrarem a esfera política continuam determinados por suas pulsões e interesses próprios: os primeiros pelo desejo de bens e de uma vida refinada e cultivada no conforto e no ócio, os outros pelo desejo de independência e segurança, para viverem livres, como quiserem; naturalmente, mantémse uma desconfiança recíproca. Não desaparece o conflito, nem se trata de negar as pulsões. Trata-se ao contrário, de permitir sua realização mediante o estabelecimento de um espaço de compromisso, de um justo meio aceitável para todos. De um lado, modera-se a riqueza de uns; por outro, limita-se a independência dos outros para que a República possa existir e cada um viver, segundo seus interesses, o melhor possível. O bem se produz pela subordinação das aspirações de cada um ao interesse superior da República, como ser dependente e não autárquico, na vida da comunidade política. 
Para uma República, a melhor comunidade política é aquela que é constituída por gente média, onde a classe média é numerosa, ou ao menos mais forte que as outras duas, ou então, que uma das duas, pois o seu concurso faz pender a balança e impede os excessos contrários. Sabe-se, desde a Política de Aristóteles, que quem tem uma quantidade moderada de propriedades se inclina mais a comportar-se de maneira razoável que os extremamente ricos ou os extremamente pobres. Os primeiros tendem a ser arrogantes e baixos em grande escala, e cometem atos de injustiça. Quem foi criado no luxo nunca se acostuma a ser governado, enquanto os pobres tendem a ser demasiados humildes ou servis.

Disso exposto decorre-se algumas idéias básicas que parecem constituir a vida republicana: a) antes que muitas leis regulamentando tudo, as atividades mais banais da vida particular e privada das pessoas, ou atividades profissionais e científicas, poucas leis delimitando as funções do Estado como mediador de conflitos entre cidadãos; b) uma educação para o exercício da cidadania, pois a República exige a participação política das pessoas; c) mais importante que bons governantes, são necessárias boas leis; d) o mais importante para a constituição de uma República democrática não são as eleições de governantes, mas a fraternidade, a igualdade e a liberdade dos diversos grupos sociais que a compõe, autodeterminarem seus destinos, seus costumes e suas leis, e o respeito mútuo e a tolerância com as escolhas individuais e de grupos distintos: governantes são coisas mutáveis, substituíveis, e, talvez, dispensáveis. Quanto mais as pessoas forem virtuosas civicamente - isto é, ciosas de distinguir o bem comum dos interesses privados - maior será sua participação no poder, nem que seja de fora, verificando, discutindo, cobrando; ou seja, quanto mais republicanas forem as pessoas participando, mais democrático será o poder, pois a República é o regime do autogoverno: sua grande convicção é que os seres humanos são capazes de governar a si próprios.

Por último, mas não menos importante, não se pode esquecer a séria questão da arregimentação, já que o republicanismo não deixa de ser também uma espécie de chamado ao dever militar, e todo cidadão sendo considerado um soldado. Não há República sem pátria. Esta, em primeiro lugar, é o espaço comum, coletivo, público - diferente do que é privado ou particular. Em segundo, é a conjunção de um intenso alvo afetivo. A pátria envolve amor, identidade, pertencimento. Nela, o bem pessoal é requisito para produzir o 
bem social. Individualmente tenho de agir bem. Só quem atinge esse nível de conduta é cidadão, porque a República é o regime da ética na política.

As Repúblicas são sérias, bem ordenadas e sempre prontas para a sua auto-defesa. Para tanto, e como demonstra a história, quem quer a paz prepara-se para a guerra; há que se manter um estado de vigilância permanente, pois via de regra uma República é forjada em batalhas e sustentada por cidadãos ativos e guerreiros, e pode legitimamente aspirar a conquistar novos domínios, para assegurar a própria liberdade. O republicanismo contém uma dimensão imperialista, na medida em que são raras as Repúblicas livres sem cidadania militar; de fato, mesmo sob condições diferentes daquelas de Roma, republicanistas tendem a imitar a grande República: as instituições militares fazem parte da condição de cidade livre, e a disposição de lutar pela liberdade é vista como parte dos deveres cívicos comuns da cada um, ao mesmo tempo que a guerra é considerada pouco mais que a continuação da política por outros meios.

A maior ameaça à integridade da República encontra-se quando seus cidadãos não se sentem mais preparados a lutar por sua liberdade, em face das agressões da tirania, mas, ao invés disso, se dispõem a colocar a defesa inteira de suas liberdades nas mãos absolutamente não confiáveis - de representantes políticos junto ao Estado ou de tropas pagas e mercenárias. A República é o regime político que mais exige dos cidadãos, pois, repito, as mesmas pessoas que obedecem mandam! Somente nela, portanto, não se legisla basicamente para os outros, mas para todos, isto é, para si mesmo e os outros. Isso requer um grau de autodisciplina desnecessário em outros regimes. A virtude política deve ser renovada continuamente em todos os grupos e classes sociais. Não obstante, o mérito específico da República é que nela a esperança de ascender às honras públicas, de fazer uma carreira por seus próprios esforços, é igual para todos: não apenas torna possíveis a liberdade e igualdade perante a lei para o corpo inteiro dos cidadãos, como também permite que floresça o cultivo das virtudes, sem que nenhuma suspeita possa medrar a seu respeito.

\section{1 - Aspectos da República Contemporânea}

Da forma como foi colocado acima, ao fim da leitura pode parecer que se elaborou apenas uma visão idealista da República. Ainda que o idealismo não seja alienígena à 
República, afinal está imbuída no espírito cívico que traz embutidos princípios éticos (o sentimento de dever e abnegação) e uma idealidade da humanidade (a começar pela possibilidade de uma certa racionalidade ou razoabilidade entre as pessoas e seus interesses), a realidade empírica parece negar ou ficar invisível nessa exposição da República. Porém, não creio que isso invalide a exposição, na medida em que a mesma tem a função primeira de destacar como a política se distancia das intenções dos teóricos e executores.

Há um consenso no pensamento político que vem se formando desde Hobbes e o seu Leviatã: o Estado é pensado, entendido e construído, como um organismo para garantir a duração e a permanência da vida social e política, com instrumentos de força e coerção para manter a ordem pública, deixando os cidadãos procurando o sucesso da vida particular no meio social, independente de ter ou não virtudes cívicas ou éticas. Tornourse aquele que garante que não se precisa deixar os afazeres particulares ou os prazeres para participar de assembléias ou construir estradas, a não ser quando isso é por vontade própria ou requisitado por esforços de guerra ou catástrofes naturais. Sua função é canalizar os diversos interesses privados do interior da sociedade para produzir fins sociais positivos, salvaguardando os interesses mais egoístas e mesquinhos de confrontos, de alguma forma prejudiciais à convivência social.

O Estado tornourse mantenedor das instituições que amoldam os indivíduos para a realização da vida social, e deixando a prática política aos governantes e políticos profissionais, principalmente após a instituição e difusão de estados republicanos pós independência americana e Revolução Francesa, que transforma o Estado naquele que deve atender ou amenizar às desigualdades sociais, favorecendo os desfavorecidos socialmente, através da maior contribuição dos favorecidos. Em épocas mais recentes, os Estados, com certas instituições previdenciárias mínimas, têm absorvido a função da família, de abrigo, de acolhimento social, assim como muitas outras para inúmeros solitários e abandonados. Sob a forma do Estado pluripartidário e com enorme nível nacional de integração, assumiu, para um número cada vez maior de pessoas, o papel de unidade de sobrevivência, parecendo indispensável e permanente. 
Porém, esse substancioso esplendor do Estado contemporâneo não traz à tona que, no decorrer do último século, são cada vez menores as exigências de participação política ${ }^{56}$ e comportamentos éticos dos indivíduos particulares para a virtude da sociedade ou do Estado Republicano. A idéia de que a República exige uma sucessão de atos heróicos e uma abdicação contínua por parte dos cidadãos descreve um ideário típico de outros momentos históricos, mas é inaplicável no contexto das sociedades industriais da atualidade. Ora, o ato heróico faz parte da tradição republicana, mas ele serve para descrever um momento da vida política que é aquele da fundação, e não o cotidiano de uma República. Imaginar um corpo político em estado de constante mobilização certamente nos obrigaria a imaginar uma sociedade pouco compatível com as exigências atuais de um tempo que viu expandir, notavelmente, a franja de direitos associados ao indivíduo e aos interesses dos grupos particulares, onde todos estão voltados para seus interesses próprios, principalmente, os econômicos.

A complexidade do fenômeno político contemporâneo preocupa porque vem paulatinamente perdendo valor e importância, seja na vida prática das pessoas, seja na reflexão teórica, havendo uma relação de indiferença ou mesmo desprezo ${ }^{57}$, que está criando um tipo de alienação diferenciada e muito perigosa, onde se ignora a coresponsabilidade de todos pelos destinos humanos. Os Estados contemporâneos estão cada vez mais administrados, burocratizados, racionalizados, tornando-se assistencialistas, e a participação fundamental das pessoas na vida pública se concentra apenas no pagamento dos impostos: somos mais contribuintes do que propriamente cidadãos. Eventualmente vota-se. Há pessoas que militam em partidos políticos e há políticos profissionais que forjam as disputas dos interesses nacionais - abstração repleta de lugares comuns.

\footnotetext{
56. Devo a Renato Janine Ribeiro e o seu excelente A Sociedade Contra o Social o alerta sobre essa questão contemporânea. Ora, como diz p. 115: "A invenção da modernidade está em produzir o coletivo sem que cada ator precise tê-lo em mente; o social, o mundo comum a todos, nasceria a despeito de nossas intenções, apenas pelo jogo das forças com que lidamos. Tal jogo pode chamar-se mercado .... mas, por extensão, vale para toda a vida pública, e seu feito essencial é dispensar cada um de nós do extraordinário fardo que, na cristandade medieval ou na militância moderna de esquerda, exige, para haver sociedade, um enorme empenho pessoal." Estamos cada vez mais buscando os interesses privados e nos afastando das virtudes políticas necessárias para a vida republicana e democrática, e isso é o que abre flancos para a corrupção e a violência, para o seu crescimento, ou pelo menos para ampliação de sua percepção.

57. O que segundo Arendt é a pior coisa que pode ocorrer para a autoridade, vide Sobre a Violência, p.37 Para Maquiavel também, no Príncipe, Cap.: XIX - Como se pode evitar o desprezo e o ódio, revela que o ódio e o desprezo são os dois elementos fundamentais que se deve evitar para manter o poder.
} 
No entanto, a política entendida como governo dos homens está se reduzindo a uma arte de administrar, é algo mais econômico do que político. O pensamento científico que corresponde a essa concepção já não é a ciência política, e sim a economia nacional ou a economia social, que indica uma espécie de administração doméstica coletiva: o que chamamos de sociedade é o conjunto de famílias economicamente organizadas, de modo a constituírem uma única família sobre-humana, e sua forma política de organização é denominada nação.

Sendo na atualidade algo técnico antes do que uma ação livre do espírito, a política gera desinteresse devido, entre outras coisas, à sua crescente especialização ou por ser formulada em linguagem meramente econômica. E como está reduzida ao discurso econômico ou técnico, paulatinamente a política torna-se algo que não se deseja participar, discutir, ou mesmo pensar, porque ir às assembléias, aos debates, à praça ou à rua reivindicar e discutir, toma tempo do principal afazer, que se encontra na vida privada.

Quando as decisões que afetam o dia-a-dia são discutidas, a democracia política é inteiramente ob scurecida pelo enorme poder exercido pelos senhores dos sistemas técnicos: líderes de corporações, militares e associações profissionais de grupos como médicos e engenheiros, advogados e agrônomos. Eles possuem muito controle sobre os padrões de crescimento urbano, o desenho das habitações e dos sistemas de transporte, a seleção das inovações, nossa experiência como empregados, pacientes e consumidores, por vezes mais do que o conjunto de todas as instituições governamentais da sociedade, assim como são responsáveis pelo sistema regulatório, jurídico e legal das nações contemporâneas.

Tal tendência aponta para o fato que o voto popular está se tornando cada vez mais supérfluo, economicamente irrelevante e até um estorvo, que as instituições democráticas e republicanas são o pão do circo para manter as energias cidadãs entretidas enquanto os grupos econômicos e sociais decidem o que é relevante. A democracia e a República parecem ser o luxo que a sociedade se concede, dando-lhes a ilusão de que controlam os processos vitais, enquanto as questões são decididas em instâncias restritas, inacessíveis e livres de controle público. Embora o instinto do eleitor desconfie da irrelevância de seu voto, haja vista a abstinência que marca as eleições, a opinião pública manifesta-se abertamente, jornais apóiam ou criticam, a crítica é permitida, mas, tudo permanece igual. 
O fato é que a reputação dos parlamentos e partidos constitucionais declina constantemente; para o povo em geral, parecem instituições caras e desnecessárias.

Hoje a noção de política como esfera independente da determinação de consenso e como esfera de mediação entre forças sociais conflitantes se aproxima mais de um mito que de algo efetivo. O consenso é determinado, mais significativamente, por fatores econômicos, como equilíbrios das balanças comerciais e a especulação sobre o valor das moedas. O controle desses movimentos não está nas mãos de forças políticas tradicionalmente concebidas como detentoras da soberania, e o consenso é determinado não por mecanismos políticos tradicionais, mas por outros meios, como, por exemplo, os organismos internacionais. Governo e política foram completamente integrados ao sistema de comando transnacional da sociedade de massas volúveis de pessoas e capitais.

O fato é que, mesmo querendo discutir os negócios públicos, uma linguagem especializada e retórica impede a grande maioria da população de participar politicamente. E há um resultado estranho no que tange às eleições: ao povo se pede que vote, não nas políticas, que raramente são muito diferentes, mas nos gestores. Parte significativa das campanhas políticas se concentra na qualidade do gestor e pouco ou nada sabemos do programa político: há mais publicidade do que propaganda política. Há uma noção de que políticos funcionam como celebridades, de que campanhas políticas obedecem à lógica da publicidade e o discurso político finda como uma jogada de venda articulada, e a participação política está reduzida à escolha entre as diversas imagens consumíveis.

Os candidatos não postulam programas com base nos temas políticos e sociais, e os partidos raramente ostentam seus interesses: grande parte dos eleitores rejeitariam os candidatos que se definissem por posições de interesses materiais. Os partidos pretendem ser puros em vez de proclamar a defesa de certas categorias sociais ou programas políticos, ou apresentar claramente seus objetivos, permanecendo no mundo abstrato das ideologias e palavras de ordem no atacado, porém, pessoal no varejo. Numa sucessão política as declarações públicas dos vários candidatos são todas ótimas, mas anódinas. No entanto, quando o cidadão pergunta o que está em jogo, os defensores de um lado, qualquer lado, fala bastante mal do outro. Enfim, ou apresentam uma proposta vaga e inócua, ou fazem acusações graves e ofensivas; querem se qualificar pela desqualificação alheia. Não há discussão política de idéias. Há uma disputa pelo poder. O discurso é tão vasto que não 
compromete. Não há vínculo entre a fala e a ação. Não obstante, o sufrágio universal tem por sentido remeter à escolha de valores básicos, de políticas, não ao julgamento da competência: competências, méritos e qualidades se aferem por critérios como os do concurso público ou exames.

Há um colapso do sistema partidário, porque os partidos, cuja função era representar interesses, não mais podem representá-los, conseqüentemente os partidos se tornaram mais e mais psicológicos e ideológicos em sua propaganda, e mais apologéticos e nostálgicos em sua orientação política. Nesta época em que nenhum regime pode considerar suas idéias como evidentes ou incontestáveis, a maioria dos homens e dos partidos empregam as palavras -democracia, autodeterminação, crescimento. Esses três termos resumem o conformismo político do nosso tempo: o direito dos povos de constituírem em uma unidade soberana, a idéia do governo pelo povo como forma legítima e o progresso econômico, com a industrialização, são considerados os objetivos primordiais de todos os países. Em que contexto, por que meios se determina a vontade que tem uma população de se constituir em unidade independente? Bastam a pluralidade partidária e eleições livres para definir o regime genuinamente democrático? $\mathrm{O}$ regime que assegura a taxa de crescimento mais elevada é necessariamente o melhor?

Socializar o homem não consiste mais em educá-lo moralmente, ou melhor, civicamente, mas em introduzí-lo num maquinário que o vergará a fins sociais, que apenas por suas disposições naturais ${ }^{58}$ ele não poderia alcançar. De Maquiavel até hoje, as técnicas de conquistas e de exercício do poder se desenvolveram, adquirindo maior sutileza e elaboração racional. O que dependia da improvisação individual e da espontaneidade é hoje objeto de estudo científico, em que se baseiam práticas bem ponderadas. A violência das massas ou a "persuasão oculta",59, a organização do entusiasmo ou a lavagem cerebral oferecem aos governantes um arsenal de armas psicológicas de riqueza incomparável.

\footnotetext{
58. Acredita-se que a observância de uma ética ou de uma lei depende de haver uma força coercitiva que a imponha, e que a eliminação das regras resulta sempre na prevalência da vontade do mais forte. A crença mais arraigada é que na ausência de leis dominará a lei da selva, e que vivemos numa sociedade onde a liberdade precisa do amp aro da legalidade para se defender. Em particular, no campo econômico, toda a gente sente que, se forem eliminadas ou enfraquecidas as leis que regulam as empresas, os patrões, mais fortes, explorarão os trabalhadores.

59. As aspas ficarão claras na terceira parte, na qual será abordado algumas questões dos mitos contemporâneos.
} 
As Repúblicas contemporâneas diminuem as proibições, abolem a pena de morte, abrandam o regime de prisões, permitem práticas de aborto, de eutanásia ou descriminalizam o consumo e venda de drogas etc. Porém, o sistema disciplinar a que se está submetido, até mesmo na vida privada e íntima, cresce discreta, porém, continuamente. O Estado toma em suas mãos cada indivíduo e estrutura a forma que bem quer; estende os braços sobre toda a sociedade e cobre-lhe com regras complicadas, minuciosas e uniformes, através das quais os espíritos originais e vigorosos, as individualidades, não conseguem aparecer para sobressair da massa.

O Estado Republicano contemporâneo não dobra as vontades ou tenta dominá-las. Simplesmente amolece-as, inclina-as e as dirige; raramente força a agir, ainda que possa se opor freqüentemente à ação; não destrói tanto os inimigos ou as novidades nos costumes ou na política, tenta antes impedir o nascimento. Os Estados ocidentais não precisam tiranizar, basta apenas atrapalhar, comprimir, enervar, arrefecer, embotar, reduzir, enfim, fazer do cidadão de cada nação nada mais ser que uma manada de animais tímidos e industriosos, cujo pastor é o governo. Antes de buscar ter bons cidadãos, procura ter pessoas obedientes e úteis dentro de uma função social específica e delimitada.

Mas, ao permitir a omissão dos cidadãos sobre a coisa pública, assim como não desenvolver ou educar para as virtudes cívicas, as Repúblicas contemporâneas levam a uma crescente alienação política, gerando pessoas sem critérios para participar politicamente ou para tomar decisões, ou oportunistas que têm mais uma vida clandestina do que privada, diminuindo a privacidade de todos e ampliando a esfera do Estado sobre a vida particular. Talvez, um dos grandes problemas da atualidade não seja uma suposta privatização do público ou do Estado, como alardeiam, mas o declínio acentuado da privacidade: as pessoas têm até sua intimidade vigiada, controlada e escancarada, enfim, diminuída a uma mera interioridade.

Lembremos que o aumento do domínio e autoridade do Estado sobre a privacidade das pessoas está em sentido contrário a uma vida republicana autêntica. Do jeito como vem se dando a discussão política contemporânea, caminhamos não para tornar a República como a organização política do mundo contemporâneo, mas para a morte da vida pública e privada, para o incremento da esfera de dominação de um organismo - o Estado - de controle autoritário ou totalitário da vida pessoal. A República começa a ruir sob a pressão 
da transformação ameaçadora de todos os governos em burocracias, em governos que não são dos homens ou das leis, mas das repartições anônimas e de computadores, cuja forma totalmente despersonalizada de dominação pode acabar representando uma ameaça muito maior à liberdade. A República acaba quando cada uma das pequenas associações particulares ou indivíduos que a dividem em tantas particularidades, esquece com facilidade do bem geral, mas preocupa-se com o interesse e os direitos do corpo próprio, onde uma dignidade e privilégios querem ser defendidos e salvaguardados pelo Estado.

Montesquieu, no Espírito das Leis, alertou a política ocidental há muito tempo: a força dos Estados vem da execução de seus princípios. A República funciona sob o princípio da Virtude; é preciso que haja virtude entre seus cidadãos para que não degenere. Virtude, em sentido político, mais do que moral é o amor pela pátria e pela igualdade que acompanha a forma econômica da frugalidade, do meio-termo dentro da possessão dos bens e do exercício consciente da cidadania. Ou seja, é preciso que cada um se dedique à vida pública, cumprindo com suas responsabilidades. Não é preciso abandonar a privacidade, nem negligenciá-la, apenas não sobrepô-la ou contrapô-la à vida pública.

Como a modernidade baniu (e ainda está banindo!) a eticidade comum da vida pública e política para a moralidade pivada do lar ou da intimidade, em público, basta cumprir as leis (ou aparentar cumprir, o que é muito comum e usual), todos se desresponsabilizam e delegam ao Estado os deveres (mas exige-se cada vez mais direitos!), sem se darem conta que sem a participação política de todos, a República, por si só, não funciona, ou não tem virtudes, pois sua virtude advém da virtude dos cidadãos. Para haver República são necessários republicanos! A excelência e a durabilidade da República não dependem de recursos institucionais, por melhor planejados que sejam, senão do caráter de quem a integra.

Essa apatia política na República Contemporânea, entre outras coisas, permite que uma pessoa seja ética na vida privada, mas desonesta na sua vida pública, em especial no trato com a coisa pública, que lida com tédio e desinteresse, como coisa do governante. Uma vez que a vida se privatizou e tem a possibilidade de escolher abnegar da política, desfruta desse direito da maneira mais equivocada: temas como política, cultura, arte, que exigem alguma paciência, mais que especialização, pouco aparece na voz do cidadão contemporâneo, ou nas suas preocupações. Na verdade, a imagem pública das atividades 
políticas é algo que agrada a poucos. A grande maioria considera que a verdade é feita de imagens na mídia, que se tem constantemente de administrar essa imagem pública, e que ela é feita de palavras e gestos representados, no fundo feitos mais para agradar a platéia, do que convencê-la da verdade ou da virtude própria.

Ora, na sociedade contemporânea que preza a intimidade, a privacidade, a domesticidade do lar, e mais ainda, considera que a verdade está no íntimo, quem vive da imagem é de algum modo desdenhado, mesmo que quase sempre possa ser admirado e invejado por uma grande quantidade de fãs. Mas, o senso comum também sabe que viver no plano da imagem é estar convivendo com intrigas, fofocas e, mesmo que fascine, não é uma vida respeitada. Resultado: atualmente os cidadãos votam nos políticos, confere poder, mas tributa pouco respeito pelos mesmos ${ }^{60}$. Há dois movimentos aparentemente inversos, tanto um desgaste da política, como uma personalização do poder. A política assim manda o que tem de melhor para a vida pessoal, como a ação criativa e ética, enquanto ela própria, colonizada pela economia e pelo assistencialismo social, perde destaque.

Além disso, a omissão, a alienação, o alheamento, a apatia - que é a forma de participação política mais "atuante" dos cidadãos médios das Repúblicas - dos homens a respeito de suas responsabilidades sobre o cotidiano, tem gerado o crescimento de um sentimento de indiferença e de ceticismo, deixando na mão dos governantes ou dos representantes políticos as responsabilidades pelos êxitos ou pelos fracassos sociais e políticos, criando a ilusão de que podemos ficar reclusos na privacidade dos nossos lares, sem sermos atingidos por políticas e práticas sociais e internacionais, aliviando a consciência ao se atribuir a um outro governante ou representante, a autoria exclusiva dos acontecimentos.

O lado de fora do lar é uma espécie de limbo moral e o público é visto como um domínio do imoral, o que faz crescer a noção de que estranhos não têm o direito de falar, de que todo homem possui como um direito público um escudo invisível, um direito de ser deixado em paz, de nem sofrer comentários, nem emiti- los. O comportamento público é um problema de observação e de participação passiva, um certo tipo de voyeurismo: a pessoa

\footnotetext{
${ }^{60}$. Essa problema ficou evidente após as discussões do projeto de pesquisa "Questões sobre o Poder" de Renato Janine Ribeiro com o seu grupo de pesquisa com orientandos.
} 
está aberta para tudo e nada rejeita a priori de sua esfera de ação, contanto que não tenha de se tornar um participante ou envolver-se numa cena.

O fato é que o homem contemporâneo nas Repúblicas ocidentais, quando sobrevém na vida pública qualquer dificuldade, conflito ou problema, tende a exigir que imediatamente o Estado assuma o controle da situação, que se encarregue diretamente de resolvê-lo com seus gigantescos e incontrastáveis meios. E, no entanto, paradoxalmente, este talvez seja o maior perigo que ameaça a civilização: a estratificação da vida, o intervencionismo do Estado, a absorção de toda espontaneidade social pelo Estado, a anulação da espontaneidade histórica que nutre, sustenta e impele os destinos humanos. Ora, hoje em dia, quando a população sente uma desventura, ou simplesmente algum forte apetite, é uma tentação para ela essa permanente e segura possibilidade de conseguir tudo sem esforço, luta, dúvida ou risco - apenas ao premir a mola e fazer funcionar a portentosa máquina estatal.

Naturalmente, a espontaneidade social acabará violentada uma vez ou outra pela interferência do Estado, mas preferem isso ao auto-controle, ainda que dificilmente novas sementes frutificarão. A sociedade hoje vive para o Estado, que sobrevive com enormes porcentagens do PIB, mas cuja atuação vem anulando a espontaneidade política e social, além de muitos fenômenos culturais que são produtos dessa espontaneidade, aquilo que brota em diferentes comunidades e circuitos de forma diferenciada. Ao se instituir uma política oficial de Estado para regulamentar as entrelinhas da sociedade, não apenas faz com que grupos e instâncias se coadunem a essa política, direcionando o seu desenvolvimento, como freia novidades que não encontrarão recepção na sociedade direcionada para apreciar apenas as manifestações políticas, sociais e culturais oficiais.

Tal fenômeno gera além da incapacidade de ações autônomas, uma imaturidade para suportar as demandas da civilização contemporânea, e apenas oferece um abandono emocional da responsabilidade ética e política: se a civilização abre amplas e novas oportunidades para as realizações e satisfações humanas, ela também acarreta afastamentos pronunciados do cultivo da excelência, assim como novas formas de poder, propensas a abusos tirânicos e refratários aos controles existentes, o que representa um eclipse da 
virtude cívica e o fim da política, para o surgimento de uma sociedade polida e comercial ${ }^{61}$. O desenvolvimento de estruturas legais de autoridades estatais sobre a cultura, a saúde, a educação, a justiça e a política de forma geral, e com a emergência concomitante da burocracia e do legalismo, tudo isso acentua fortemente as possibilidades de um controle político intencional em nome dos supostos objetos públicos. Se o indivíduo moderno emancipou-se da sujeição à classe social, trocoura pela inspeção estatal em toda gama de atividades da vida. Esse controle adota a forma de autorizações, licenças, restrições e limitações específicas, assim como de fiscalização concreta: órgãos estatais e pesquisadores privados reúnem totais por espécie e publicam números, cuja finalidade consiste em mostrar por que motivo se verifica uma causa para promover ou restringir determinada atividade. O cidadão moderno vem desenvolvendo o hábito de viver pela autoridade das estatísticas!

Nossa época, por um lado, alimenta um certo desprezo pela política, por outro, tem preguiça e medo dela; os homens estão, senão aterrorizados, céticos pela desintegração ética na política e por tão pouca orientação: cada um em sua solidão e sentimento de impotência implora por muralhas que barrem o oceano enraivecido das massas desejosas, suplicando por ordem, segurança, organização, autoridade definida e reconhecida, pelo fim do debate e negociação diárias; estão alarmados com a perspectiva de demasiada liberdade, que os deixa perdidos em um vácuo imenso e namistoso, em um deserto sem trilhas, marcas ou pontos de chegada.

A ação do Estado e a tentativa de impor políticas que decorrem de posições majoritárias ${ }^{62}$ da sociedade, pode oprimir uma parte ou mesmo indivíduos dessa sociedade. A tirania do maior número deve ser incluída entre os males contra os quais a sociedade contemporânea deve se resguardar. A proteção contra a tirania dos governantes ou dos magistrados não basta. Importa ainda o amparo contra a tirania da opinião e dos sentimentos dominantes: contra a tendência da sociedade para impor as próprias idéias e práticas como regras de conduta, àqueles que delas divergem, para refrear e, se possível, prevenir a formação de qualquer individualidade em desarmonia com os seus rumos, e

\footnotetext{
61. Particularmente não tenho nada contra sociedades polidas e comerciais. Deve ser um pouco tedioso viver sem vida política, mas há virtudes evidentes de se conviver entre comerciantes bem educados e honestos.

62. A vontade do povo significa praticamente a vontade da mais numerosa e ativa parte do povo - a maioria, ou aqueles que logram êxito em se fazerem aceitar como a maioria, naturalmente através da acentuada tendência de abstenção e da grande carga de omissão da grande maioria.
} 
compelir todos a se plasmarem sobre o modelo dessa maioria. Sem dúvida, é preciso haver limites à legítima interferência da opinião coletiva na independência individual, pelo menos enquanto ela não interfere num outro.

Nada é tão violento na política contemporânea como a criação de novas leis, instâncias, comissões e, é claro, aumento de impostos. Ora, sem perceberem que leis são burladas pelo próprio Estado responsável pela sua manutenção, que as instâncias não funcionam sem o domínio público e que comissões existem exatamente para separar os problemas que são comuns a todos os interessados, transformando o político no técnico, findando a política, ou apenas burocratizando a vida social e política. E, como se sabe, em uma burocracia plenamente desenvolvida não há ninguém a quem se possa inquirir, a quem se possa apresentar queixas, sobre quem exercer as pressões do poder. A burocracia é uma forma de governo na qual todas as pessoas estão privadas da liberdade política, do poder agir; pois, como bem diz Arendt ${ }^{63}$, sob o domínio de ninguém, todos são igualmente impotentes: temos uma espécie de tirania, porém, sem tirano. E mais ainda, como salienta a autora, nada pode ser mais assustador do que o constante crescimento do prestígio dos assessores de mentalidade científica nos conselhos do governo: o problema não é que eles tenham sangue frio suficiente para pensar o impensável, mas o que eles não pensam. Em vez de entregarem-se a esta atividade antiquada e improcessável que é a política, calculam as consequiências de certas suposições hipoteticamente assumidas, sem, contudo, serem capazes de testar suas hipóteses contra as ocorrências reais.

Seria interessante pesquisar até que ponto a expectativa de eventos pelos estrategistas não contribui para provocá-los. Essa crítica se aplica também às proposições gerais alegadamente científicas: a maioria das generalidades relativas aos determinantes da política tende a estabelecer causas onde, na melhor das hipóteses, há tendências; não levam em conta todos os fatores e ampliam a ação dos que são considerados. E enquanto se discute e se preocupa com o aumentar a força do Estado, contratar mais técnicos e assessores, não se está atento para o fato assustador da ausência de poder que ele tem e do seu custo cada vez maior para se transformar em instrumento de força e violência no seio

\footnotetext{
63. Em várias obras Arendt faz críticas e análises da burocracia, aqui me aproprio da crítica da burocracia no texto Sobre a Violência.
} 
social. Quanto menos poder, mais força, conseqüentemente, maior é a violência que pratica, e mais violenta vem se tornando a reação do público contra o Estado e entre o público.

Entretanto, apesar desta esmagadora ampliação do estatal sobre a esfera privada, paradoxalmente, no campo íntimo e privado, o nosso tempo luta para a mais completa eliminação de regras, hábitos e costumes. Aí deve vigorar a liberdade mais absoluta, isenta de tabus, inibições, limites. Este princíp io foi mesmo erigido quase em valor sagrado nas Repúblicas Ocidentais. O resultado, entretanto, tem sido abrir espaço ao domínio dos predadores, onde boa parte das lutas por direitos de supostas minorias que ocorrem no mundo atual está levando a uma regulamentação extremada da vida social, dando ou criando uma força disfarçada de autoridade aos Estados, inusitada na história humana, onde cada vez mais tem o domínio da privacidade e o poder de decisão sobre as individualidades, regulamentando a vida dos cidadãos de tal modo, que suas escolhas ficam reduzidas a apenas uma intimidade que vive ou subsiste clandestinamente, sob pena de ser punida ao ser exposta, pois esbarra em "direitos" que querem submeter às vontades diferenciadas, num comportamento comum igualitário pelas suas restrições, mais do que pela sua liberdade ou alcance.

A verdade é que as Repúblicas no ocidente ensejam, no melhor dos casos, formas não violentas de dominação. Elas estão dominadas pelo que Arendt denominou de preocupações com a esfera social, que substitui ação política propriamente dita: representa a ascendência do social ou da sociedade, numa acepção heterodoxa do termo, constituindo uma anomalia ao realizar a elevação dos negócios econômicos do lar doméstico ao nível da esfera pública. Isto é, as questões de subsistência ganharam importância pública, o que diluiu a divisão entre o privado, o estatal e o público, e alterou o significado dos termos e a sua importância para a vida do indivíduo e do cidadão, a ponto de torná-los quase irreconhecíveis. Concomitantemente à emergência da esfera social, a sociedade de produtores e consumidores exigiu do Estado a proteção para o acúmulo de riquezas e o seu desfrute. A única preocupação que as pessoas passaram a ter em comum é a preservação dos seus interesses privados, provocando uma acentuada indiferenciação com a esfera pública e um aprisionamento voluntário na esfera privada, com uma conseqüente submersão de ambas na esfera social. Não se busca mais a liberdade e sim a felicidade do 
povo, a abundância material e de direitos criados com intuito de resolver, com compaixão, a pobreza da população.

O cerne da política democrática e republicana apregoada pelo Ocidente está em ser ela o regime dos muitos, inclusive dos pobres, por possuir Estados que procuram garantir a sobrevivência e a legitimidade de todos, indistintamente, por defenderem os direitos humanos e terem eleições para o executivo, o legislativo e, em alguns casos, para o judiciário. Ocorre que a política manifesta-se, não como regime político, mas como exercício social ou econômico, cuja característica consiste em ativar o desejo de todos por ter mais. Entretanto, a República está centrada na idéia romana de uma res publica, exigindo sacrifício ao bem comum, dos desejos ou interesses privados. Mas, educados como pessoas com direitos, o que apesar de ser um ganho social enorme, pois se desfruta da liberdade política há várias gerações no mundo ocidental (mesmo que poucos a exerçam consciente ou consistentemente), essa educação é omissa e negligente sobre os deveres e compromissos para que direitos possam ser exercidos ou mesmo buscados: trata da perspectiva do sujeito antes do que da perspectiva do agente, logo, dá mais importância aos direitos do que aos deveres, tanto que se fala mais de direitos humanos do que na obrigação da humanidade.

Com isso, a política contemporânea encontra-se estagnada numa encruzilhada: de um lado, tem que reprimir o que faz as massas lutarem, que é o desejo de terem mais, colocando empecilhos e dificuldades em processos reivindicatórios, encaminhando os reivindicantes aos assistentes sociais variados. Isso alimenta a apatia, a omissão, a alienação, o que faz com que ocorra perda significativa de virtudes políticas elementares para uma República: os homens se tornam apáticos, comportam-se ao invés de agir, constituindo uma sociedade de indivíduos atomizados ${ }^{64}$, cujas relações interpessoais são incapazes de criar um mundo comum. Por outro lado, aposta num desejo popular pela abnegação em prol da República, sem desenvolver nenhum processo educativo para tanto. Ou seja, nem se consegue produzir a renúncia republicana para a constituição de uma vida com direitos pela participação de todos - e não apenas coagidos pelo Estado - nem se consegue satisfazer a premência dos desejos populares que crescem cotidianamente sem

\footnotetext{
64. A atomização da sociedade não implica o florescimento da individualidade consciente, mas o seu oposto: o domínio das opiniões recebidas sem critérios. Como há inúmeras correntes se digladiando, cada qual receberá a adesão de alguns. Não por boas razões, mas por impulsos de momentos, ou a interesses privados.
} 
limites de uma sensibilidade ampliada republicana ${ }^{65}$. Resultado, aumento de conflitos e reações enfurecidas por questões particulares - por vezes banais - a uma categoria, a um grupo, a uma pequena parte, onde os custos do conserto dos estragos realizados pelas manifestações e protestos são superiores aos benefícios conquistados.

Enfim, a política ocidental está se caracterizando como uma luta por direitos que implicam geralmente uma titularidade individual ou grupal dos mesmos, cujo reconhecimento e satisfação são exigidos do Estado, mais do que da sociedade. Ora, isso acarreta a constituição do Estado como um poder próprio, externo, distinto dos reivindicantes. Corre-se o risco de adquirir ao invés de direitos, privilégios, e pouco ou nada afetar a natureza do próprio Estado, ou tornando-o mais despótico.

A população, inclusive os pobres e desorganizados, têm uma crescente noção de seus direitos, desejos cada vez maiores por conforto ou bens, e busca-se redução da subserviência, da dependência, que foram sempre fenômenos tão tradicionais da história. Entretanto, mais do que uma busca pela independência e autonomia, deseja-se uma dependência de um Estado que impeça as intempéries do dia a dia: ninguém pensa na possibilidade de levar a bom fim um negócio importante sem alguma interferência estatal. Todos os setores econômicos, inclusive aqueles geralmente avessos aos preceitos estatais sobre a economia, começam a pensar que a culpa pelo seu não desenvolvimento é o Estado que não guia nem o apóia como deveria. A maioria já pensa que a ordem pública só poderá ser garantida pelo Estado: o governo substituiu, desta maneira, o lugar da Providência Divina e é natural que cada um o invoque para resolver suas necessidades particulares. Há uma constante ampliação da exigência de direitos que sejam garantidos pelo Estado, porém, falta o poder republicano que responda a esse desejo popular que está ocupado ou sendo forjado pelo espetáculo midiático que promove maiorias, nteresses "nacionais", anseios "populares", vontades "legítimas".

O homem desfruta hoje de uma paixão mole e, contudo, tenaz e inalterável que se mistura e até se entremeia com virtudes privadas, como o amor à família, a regularidade dos hábitos, o respeito das crenças religiosas e até com a prática morna e assídua de um tipo

\footnotetext{
65. Um republicano vê no outro um co-cidadão, não, como geralmente ocorre, como mais um outro cidadão, que por ser desconhecido (e até que se prove o contrário, com certeza, para a maioria, suspeito!), pode eventualmente ser usado para satisfazer desejos particulares e em detrimento do mesmo. Ora, um republicano sabe que a perda de um dos seus cidadãos representa uma perda para a República inteira!
} 
de honestidade, que tem permitido criar pessoas metódicas, porém, cidadãos medrosos. Se confessassem o que cada um quer do Estado, diriam que supra alguma incapacidade particular, que privilegie a função específica ou a importância relativa de cada um perante a sociedade. Sim, mas há ainda o fato claro e distinto: cada um procura tirar mais que benefícios, e entre todos eles, mais que tudo, os visados privilégios. Diante de todos, cada um afirma, defende e tenta impor alguma superioridade sobre maiorias e imensas minorias: uns por serem médicos, outros por serem juízes, outros por serem políticos, outros por serem engenheiros, enfim, cada um, seja pela profissão, pela cor, pela idade, pelo sexo, pela religião, pela crença exige que a lei lhe garanta uma diferenciação dos demais. A igualdade, com certeza, é uma idéia de idealistas, mais do que um sentimento cívico, uma vontade política ou uma prática social.

\section{2 - Promessas Republicanas em Práticas Democráticas}

A comunicação - instrumento por excelência da política - entre os homens requer amizade e justiça, e é por essa razão que a amizade cívica é necessária na polis, pois é ela que mantém a união dentro do Estado. Afirma Aristóteles na Política que em toda comunidade política se encontra de maneira co-extensiva alguma forma de justiça e de amizade, instituidoras do comum. A força motivadora principal na construção do Estado é a amizade pessoal que se constitui em cidadã ao instituir a sociedade civil, que leva a uma colaboração para objetivos comunitários mais fortes que uma relação meramente jurídica; a própria justiça, num sentido verdadeiramente político, depende de uma relação interpessoal entre iguais, na qual todos participarão rotativamente nos negócios do governo.

A homogeneidade social ambicionada no Ocidente desde os modernos oculta da vista duas fontes inesgotáveis de heterogeneidade: o intelecto e a riqueza. A capacidade intelectual, de vigor e criatividade está desigualmente distribuída; é o que também permite acúmulos distintos de riquezas. A desigualdade de capacidade conduz a uma desigualdade de expectativas e de competências entre todos os homens que desejam, muitas vezes, as mesmas coisas, que pode resultar numa inimizade e ser intensificada pela deficiência ou desconfiança que os homens sentem uns pelos outros como salienta Hobbes no seu Leviatã. 
Quando pessoas de competências diferentes disputam as mesmas coisas, os mais competentes invariavelmente ganham. Até incompetentes consideram, senão justo, inevitável. A discórdia aparece quando se começa a questionar a justiça dessa inevitabilidade e parcelas significativas da sociedade reivindicam algum tipo de compensação dos mais competentes para suas "incompetências".

Em pequenas sociedades e comunidades, onde todos se conhecem, alianças e confianças mútuas decorrem da familiaridade, camaradagem, compadrio. Muito diferente ocorre no mundo atual, onde o homem nasce com mais dimensões culturais e territoriais que pode optar, ou até mesmo captar, e, solitário, tem que escolher diariamente seu destino numa multiplicidade de oportunidades ao seu alcance. Como ficou consolidado desde Hobbes, o indivíduo em si mesmo é pré-político e executor da lei da natureza, detendo o direito de empunhar o gládio da justiça em sua própria causa.

O fato político decisivo é que os laços dos homens não estão atados em definitivo. Pode se separar de sua família, dos seus pais ou dos seus filhos, da sua igreja, do seu clube, do seu time, dos seus amigos, pode mudar de emprego ou profissão, pode mudar de cidade, de estado ou de país. O que impede? Nada, absolutamente nada está restrito ao homem moderno, e se fica num lugar e convive com certas pessoas, ou inúmeras, é porque há uma reciprocidade de interesses e afetos, caso contrário, havendo desgosto ou desprazer das partes, ou de pelo menos uma das partes, a relação é rompida.

É um traço específico da liberdade moderna essa possibilidade infinita de escolhas, até as mais cruéis, como pegar um avião e voluntariamente joga-lo contra prédios. Tais gestos de autonomia dos indivíduos tornam imprevisível o futuro. Na vida civil o problema se complica ainda mais pela presença do amor à glória, ao orgulho ou à vaidade que Hobbes chama de prazeres do espírito, que provêem da vanglória e baseiam-se nas boas opiniões que um homem ouve ou que tem de si mesmo. Essas opiniões se apóiam sempre em comparações com os demais. Cada um deseja que os outros o apreciem como ele se aprecia a si mesmo. Ao primeiro sinal de desprezo e de desdém está disposto a destruir ${ }^{66}$ aquele que desdenha. Ou, como diz Nietzsche no Humano demasiado humano, raramente se erra, quando se associam as ações externas à vaidade, as medíocres ao costume e as

\footnotetext{
66. O termo é dramático, mas aplicável a atitudes e coisas banais. Não destruímos aos outros matando, o desprezo, a indiferença, o tripúdio são por vezes mais cruéis que a própria morte.
} 
mesquinhas ao medo. Os homens não se envergonham de pensar em coisas sujas, mas ao imaginar que lhe são atribuídos esses pensamentos sujos. A maldade é rara - os homens em sua maioria estão ocupados demais consigo mesmos para serem malvados.

A verdadeira causa de não conformação das pessoas com o espaço público é que a política, em grande parte, priva os homens comuns da oportunidade de fazer alarde de sua sabedoria, seus conhecimentos e sua eloqüência ao deliberar ou parecer deliberar acerca de questões de suma importância. Em princípio, os homens escolhem ser virtuosos, quando ser virtuoso significa merecer aprovação pública e esplendor: é humano desejar a aprovação e o amor de seus congêneres.

Não obstante, por mais egoísta que pareça qualquer homem, ou que os pensadores o tenha feito através da história, há alguns princípios que o faz interessar-se na fortuna dos demais e faz que a felicidade deles seja necessária para ele mesmo. O homem está atado à humanidade pelos laços imediatos dos sentidos e o sentimento, porém está preso a seus concidadãos como tais, pelos laços mais débeis e induzidos do cálculo ou da razão, os quais derivam quase sempre de considerações de utilidade. Assim, uma sociedade política não precisa se dirigir até a perfeição da natureza humana, o que seria inútil ou tirânico, basta salvaguardar a justiça.

O homem se não é bom, pode vir a ser, pois astuto, aprende com erros cometidos. Encontra dificuldades para se proteger das conseqüências do comportamento de outras pessoas, limita as liberdades naturais precárias a fim de conseguir um grau maior de tranqüilidade e paz, através de um acordo de conjugação de esforços e respeitos mútuos que permite a cada um o desfrute de sua liberdade, mas sem invadir ou ser invadido pela liberdade alheia. O resultado tem sido o gradual estabelecimento das Repúblicas, que surgem por um processo de amadurecimento pessoal e social espontâneo desde o Renascimento, desenvolvendo-se a partir dos esforços do homem para usar a razão, com o fim de melhorar sua vida.

Numa República, como pessoa pública cada um governa seu "reino" de forma legítima enquanto promove o que é mais vantajoso para si mesmo sem prejudicar os demais e contribuindo com os demais quando solicitado. Não se pode pensar que ele usufrui a mesma posse plena e ampla de si próprio que um proprietário tem sobre seus bens. É um equívoco qualquer pessoa afirmar que está livre de todas as obrigações para com os demais; 
se falhar nisso, se agir injustamente para com os outros e persistir no seu comportamento, então será hora de aplicar a lei que estabelece que se pode repelir a violência pela força. Ele perde credibilidade!

É aqui que se legitima a resistência pela força: como todo funcionário público - o cidadão - que ultrapassa os limites de seu cargo deixa de ser considerado uma autoridade; ao se resistir a suas ações retirando-o do espaço público, não se está resistindo ou afastando uma pessoa pública, mas apenas alguém que, de forma injusta, detém um poder público e pode legitimamente ser desautorizado de exercer e repelido para uma privacidade fechada. Se uma pessoa se conduz de modo a diminuir o direito de outra pessoa, converte-se em nada mais do que um homem comum e sem traços de civilidade; necessita de repreensão e educação, pois na falta dos costumes civilizados, domina a opressão e loucura das profundezas de Dionísio.

Isso significa que não é preciso mais lhe atribuir autoridade alguma, nem qualquer tipo de obediência, apenas respeito por ser uma pessoa com direitos, mas não se pode tributar igualdade, na medida em que não há reciprocidade nos gestos de civilidade: é um dissidente social! E se insurgem contra qualquer um de forma recorrente, é necessário que sejam chamados à parte da convivência social, pois são anti-sociais. Quando as pessoas estão sem receio de transgredirem as leis, não devem mais ser consideradas livres e públicas, e sim criminosos privados. Torna-se lícito resistir a eles, do mesmo modo que é justificável resistir à força injusta de quaisquer outros indivíduos criminosos ou não, tornando-as pessoas privadas e transgressores do público.

O desejo da comodidade e a esperança de lográ- la por meio de sua laboriosidade é o que inclina aos homens à paz. A razão atuando junto com essas paixões sugere regras para viver pacificamente em comum e inventa meios de redirecionar e intensificar o desejo de comodidade, de tal maneira que se sobreponha e anule os efeitos destrutivos do desejo de bens ou glória. A República é a substituição do elo dos interesses da busca dos bens e glória que distingue, pelo elo dos interesses da busca das virtudes próprias, que quer igualdade de condições para publicizar suas conquistas: a glória própria advinda dos méritos particulares - a dignidade! A inteligência que preside as fundações políticas republicanas reivindica a disposição coletiva para o bem comum pelo direito, estabelece as leis e faz delas as condições reais da convivência política. É a astúcia do legislador atuando enquanto 
civilizador, ele não pressupõe um espírito social inato, assim o induz pelas leis e pela educação; forja a crença no coletivo público para criar entre os homens a disposição cidadã para a harmonização dos interesses e a regulação de seus conflitos. Nessa perspectiva, a República não tem como objetivo fundamental ser boa, mas ser útil.

Há sempre um índice de imprevisibilidade na ação dos homens e nunca sabemos ao certo o resultado dos feitos, que podem ser modificados ou revertidos: não vivemos sozinhos no mundo e toda ação finda numa reação. Onde cidadãos livres e iguais convivem na esfera dos negócios tudo é incerto e imprevisível, por vezes, irreversível, e só o ato de prometer elimina parcialmente a imprevisibilidade e permite perceber novas possibilidades de ação. O consentimento e as promessas são o fundamento único e verdadeiro de toda autoridade pública. Ainda que as questões humanas nunca permitam um consentimento completo e só muito raramente atinge-se algo que se aproxime dele, que a conquista ou usurpação, ou mais simplesmente a força, por meio da dissolução dos antigos governos, estão na origem de quase todos os governos que o mundo viu nascer, e nos raros casos em que aparentemente tal consentimento existiu, este foi em geral tão irregular, tão limitado ou tão contaminado pela fraude e pela violência que não se pode atribuir a ele grande relevância, o ato de consentir e de prometer é uma das bases de sustentação republicana.

Uma República funciona quando a lei tem poder sobre os cidadãos e a autoridade dos cidadãos advém da disposição de obedecer de forma incondicionada, pois se baseia num tipo de legitimidade do poder. Aliás, autoridade coercitiva seria uma contradição, na medida que a coerção pertence à força e a autoridade está no campo do poder. É incompatível com a concepção de poder legítimo, entendido no sentido de considerado como advindo por parte de indivíduos ou grupos que participam do poder.

No âmbito social, onde mais propriamente se situam as relações de autoridade, quem possui autoridade tem o direito de mandar e exercer o poder, e os que estão sujeitos à ela têm o dever de obedecer ou seguir suas diretrizes. Autoridade fundada em específica competência publicamente respeitada pelos demais entes sociais. Pode-se dizer que na autoridade é a aceitação do poder como legítimo que produz a atitude mais ou menos estável no tempo para a obediência às ordens ou às diretrizes. O poder político jamais se reduz ao simples uso da força. Ele requer algum nível de consentimento dos "dominados". 
Hoje não nos contentamos em mencionar o consentimento - acrescentamos que ele se obtém pela palavra e que precisa ser constantemente reposto.

A soberania civil depende do reconhecimento de que o poder é apenas secundário e derivativo nos governos. A fonte e causa eficiente é o povo, de modo que os representantes eleitos do povo têm o direito de julgar da necessidade pública e lançar mão de qualquer instrumento quando a liberdade e a segurança do povo está em jogo, mas essa soberania está limitada pela autoridade concorrente dos outros poderes, o Parlamento, o Judiciário e, sem dúvida, a opinião pública. O Estado é o nome da pessoa artificial que representa aqueles que detêm o poder soberano, e seus atos de representação são tornados legítimos pelo fato de serem autorizados por seus próprios representados, o povo, o ilustre desconhecido, todos nós. Todo indivíduo é um cidadão em potencial, que só se realiza na medida em que liga sua vontade à dos outros membros do conjunto, com o fim de constituir o poder nacional.

Uma decisão pode satisfazer a grande maioria e, ainda assim ser ilegítima - quando a união de todos se dá por vantagens pessoais ou grupais, e não pelo bem comum. $\mathrm{O}$ bem comum não coincide com o bem de muitos, nem mesmo com o bem de todos, como alerta Rousseau no seu Contrato Social. E isso porque o essencial na República não é quantos são beneficiados, e sim o tipo de bem que se procura: é um problema qualitativo, não quantitativo. Bem comum é um bem público, que não se confunde com o bem privado. Logo, para atribuir ao povo o direito de tomar decisões finais em situações que não estejam reguladas por leis, torna-se essencial que o povo não seja visto como uma multidão, mas como um corpo detentor de uma personalidade coletiva e de uma única voz que expressa seus objetivos comuns. E, sem dúvida alguma, pelo menos no ocidente, o clamor popular é captado melhor através das práticas democráticas.

A democracia é uma prática política e social que se concentra no presente da vontade coletiva ou da maioria; empenha-se na pura atualidade do interesse popular, estampado a cada momento através de rituais de seus procedimentos de assembléia e votação. Como forma política se quer fundada na universalidade da liberdade e da igualdade, apresenta-se como universal e absoluta, necessária e permanente. Porém, da forma como funciona, a democracia nada tem a ver com a idéia de um regime ideal - é uma prática prosaica, que obriga governantes, instituições, grupos, pessoas à competição com 
seus rivais - competição permanente e sujeita a regras determinadas. Democracia pressupõe não só a escolha dos governantes, mas o debate sobre as decisões dos governantes e a intervenção ativa dos eleitos e eleitores nesse debate. A eleição de deputados representa antes um símbolo do que a realidade da democracia moderna: a realidade é os sindicatos, os grupos profissionais de empresários ou produtores, comerciantes, agências reguladoras, imprensa, intelectuais, cientistas e artesãos.

A democracia tem como uma de suas características o direito de dizer e de fazer o que se desejar: cada um pode seguir o modo de vida que melhor lhe pareça, sendo assim o regime de governo e prática social que fomenta as maiores variedades: todo modo de vida pode se encontrar nela. O objetivo da democracia não é tanto a virtude, mas a liberdade, tanto que a tirania e democracia têm em comum o rendimento aos desejos sensuais, inclusive os ilícitos, com a diferença que a democracia é a organização de uma rivalidade pacífica pelo exercício do poder pessoal.

Com democracia a unidade do grupo social passa a ser associada ao exercício "consciente" do conflito que se generaliza e difundise por toda sociedade. Esta expansão não é só quantitativa, mas principalmente qualitativa, já que não se trata apenas do conflito de classes, mas de valores, de opiniões, de posições e de ações práticas. A sociedade se expõe a uma constante in determinação; impossível definir segura e perenemente o que é o bem e o que é o mal, o que se considera legítimo e o que se afasta como ilegítimo, quais os critérios do verdadeiro e do falso, do proibido e do permitido. Até mesmo a divisão social de papéis torna-se movediça, na medida em que os referenciais que situam uns em relação aos outros demandam uma batalha quotidiana para serem aceitos e respeitados. Se a democracia depende do consentimento - não presumido, mas dado, e não uma só vez, perdida no passado, mas constantemente reiterado ou retirado, então a palavra democracia é carregada de persuasão.

O perigo da democracia é a decadência num igualitarismo permissivo, que permite a tirania da maioria sobre os espíritos de quem são superiores em matéria intelectual. É o que faz existir uma disposição da democracia à mediocridade, um perigo constante; o êxito da República e da democracia depende do povo e seus líderes respeitarem a excelência humana e a medida da virtude e do autodomínio. A valorização é ndispensável a um entendimento adequado das coisas sociais ou políticas. Não se pode esquecer que a 
liberdade pode se converter em licenciosidade pela ausência de freios morais e políticos, o que é típico do homem democrático, mas não republicano, pela irrupção do desejo imoderado de satisfazer carências supérfluas além das carências necessárias, pela ausência de respeito às leis e pela condescendência geral para com a subversão de toda autoridade. Os defeitos das assembléias populares são a incompetência, o domínio da eloqüência e da demagogia, a formação de partidos que obstaculizam a formação de uma vontade coletiva e favorecem a rápida modificação das leis.

A democracia nem sempre escolherá a melhor política. Sua virtude reside no fato de ser o estilo de governo capaz de corrigir, com maiores probabilidades e rapidez, com menores traumas, as políticas erradas. Numa democracia degenerada os decretos são aprovados pelo capricho popular que suplanta as leis, tornando o povo na prática um tirano; a massa crédula de cidadãos é manipulada pelos demagogos, que lisonjeiam a assembléia popular, fazendo-a crer que tudo deve estar sujeito à sua decisão, tornando os Estados populistas, nos quais prospera a retórica, o engano, e por isso se debilita o poder. Além disso, uma coisa é a democracia da direção política, o que ocorre com a instituição dos parlamentos e partidos políticos, outra coisa é a democratização da sociedade. Pode muito bem existir um Estado democrático numa sociedade em que a maior parte das instituições não possui práticas democráticas. 


\section{Parte 3: Decorrências Práticas: uma política de longo prazo}

De tanto ver crescer a injustiça, de tanto ver agigantar-se o poder nas mãos dos maus, o homem chega a rir-se da honra, desanimar-se da j ustiça e ter vergonha de ser honesto!

Ruy Barbosa 
Chega-se a questão final: temos hoje um animal político agindo sem virtude numa República degenerada e temos um animal social numa sociedade de massas inconformado e desejoso de mais: o animal político está adormecido ou rendeutse ao comerciante cordial? É fundamental saber a resposta dessa questão, pois há decorrências de curto, médio e longo prazo que determinam caminhos diversos.

Uma sociedade comercial tem muitos encantos, boas oportunidades, momentos de felicidades, mas uma tendência brutal para a futilidade, para o cultivo do temporário e do prazer imediato. Pode ter glória e honra, pode ter virtudes e benefícios, mas desfruta de uma liberdade morna num mar de calmarias e rotinas, que castra os saltos audaciosos que buscam novos caminhos, que não querem apenas melhorar o que já existe, mas inventar o melhor e criar o bem. A tendência mundial tem sido a construção de uma sociedade de massas interplanetárias, buscando o aperfeiçoamento de estruturas estatais e sociais, que acomodem os interesses de contribuintes produtores e consumidores. $\mathrm{O}$ problema desse tipo de sociedade é que deixa pouco espaço aos inúmeros indivíduos que não conseguem conviver com a rotina, que não conseguem ter lugar ou tempo para manifestar de forma adequada suas individualidades.

Alavancar o progresso e administrar a riqueza acumulada é a função depositada pela sociedade à política. Na modernidade, a própria idéia de comunidade política é entendida como riqueza comum, resultando de atividades solitárias. Uma vez que o mais importante é o funcionamento, a produtividade e a expansão da sociedade, o governo é assumido pelos experts, pelos detentores do saber a respeito do funcionamento da economia. Numa situação como essa se tornam supérfluos quaisquer ações e discursos. Nesse caso, cada um deve se preocupar com os seus afazeres. Quando se transforma a política em administração das coisas, tende à coisificação das pessoas, e nessa situação, resta à ação e ao discurso apenas a intimidade de grupos particulares.

Naturalmente, há ação política, mas qual o seu local no mundo cotidiano do comerciante? Qual o seu alcance para além dos atores e espectadores políticos que se ocupam de forma diferente do espetáculo político contemporâneo? Ora, peguemos o orçamento de um Estado contemporâneo; poucas coisas podem ser feitas porque ele existe em função da inércia estatal e de custos sociais pré-determinados. O que resta aos governantes ou aos políticos? Fiscalizar e administrar o uso. Eventualmente jogam centavos 
daqui para lá em nome de promessas de benefícios que podem ser geradores de malefícios maiores futuros.

E, no entanto, se não há caminhos abertos para a ação política, os mesmos não estão fechados; são antes inexistentes por falta da ação de um agente político criador, mas não estão impedidos de ocorrer. Isso não é um alívio, porque é sempre mais fácil iniciar uma ação política lutando contra práticas políticas já existentes, do que tentar incutir novas práticas onde não há práticas, mas um hábito mormacento de comprar feito ou pagar alguém para fazer, antes de tentar fazer. A dificuldade do mundo contemporâneo não é fazer, nem falta de pessoas dispostas a fazer, mas sim, há o que fazer? Ou, será que se deve sair dessa inércia social que tem um fundo de agradabilidade razoável, visto haver poucas revoltas hoje em dia? Sem dúvida, as massas são capazes de decidir se, quando e para onde se movem; precisam ter o direito de ficar parada e apreciar um lugar, em vez de serem forçadas a viver permanentemente em marcha. Afinal de contas, o direito geral de controlar seu próprio movimento é a demanda definitiva da cidadania global. E quem garante que uma sociedade comercial não é a melhor das sociedades?

Se a política é algo importante que pode transformar comerciantes em cidadãos, portadores de virtudes humanísticas da liberdade, igualdade e fraternidade, e havendo certo repúdio para o debate e a ação política na sociedade comercial, de onde retirar energia para chamá-los para uma prática política consciente e consistente, se não querem agir ou pensar para além dos negócios próprios? A contingência da liberdade humana não pode ser evitada, e a questão significativa que pode ser proposta é se a liberdade nos agrada ou não, se estamos dispostos ou não a pagar o seu preço.

\section{1 - Da Liberdade à Violência}

(1)

A luta entre liberdade e autoritarismo é a mais nítida característica da história com que mais cedo nos familiarizamos nas escolas. Toda história do pensamento político pode ser considerada como uma longa, ininterrupta e apaixonada discussão em torno dos vários modos de limitar o poder e a máxima, segundo a qual, quem detém o poder tende a dele abusar. O sentido forte e usual de liberdade é acabar com os limites dos grilhões, do 
aprisionamento, da escravidão. A liberdade tem origem no desejo do indivíduo ou de grupos de indivíduos de ser seu próprio amo e senhor: quer que a vida e as decisões dependam dele mesmo e não de forças externas de qualquer tipo; quer ser instrumento dele mesmo e não dos atos da vontade de outros homens; quer ser sujeito e não objeto, ser movido por razões, por propósitos conscientes que sejam seus, não por causas que lhe afetam a partir de fora.

Diz-se normalmente que alguém é livre na medida em que nenhum outro homem ou nenhum grupo de homens interfere nas atividades desse alguém. O resto é extensão desse sentido, ou então é metáfora. Lutar para ser livre é procurar remover obstáculos; lutar pela liberdade pessoal é procurar pôr um freio na interferência, exploração e escravização por parte de homens cujos fins são deles mesmos e não nossos. Liberdade, pelo menos em seu sentido político, é o mesmo que ausência de tirania ou de dominação ${ }^{67}$.

Mas, a liberdade também é um exercício interior de autonomia. Com efeito, dependendo das inclinações espirituais e dos esforços que o homem fomente e faça prevalecer em si, ele pode se entregar ora à influência de um determinado dogma, ora à influência de uma pessoa, ora ser autônomo. O que define o homem é o fato de ele não receber, desde o nascimento, uma essência já pronta, mas ser capaz de lhe dar uma forma segundo sua livre escolha. Essa capacidade de configurar sua própria essência não contradiz toda e qualquer determinação exterior, seja ela considerada material ou espiritual.

Infelizmente, tudo que se apresenta como óbvio e simples acaba sendo bastante questionável quando nos detemos sobre a questão. Será que toda dignidade e a defesa que a liberdade induz e carrega, consistiria numa meta "negativa" de contrapor-se à interferência externa? Todo apelo em favor de liberdades civis e de direitos individuais, todo protesto contra a exploração e a humilhação, contra o abuso da autoridade pública ou a hipnose em massa dos costumes ou da propaganda organizada, tem suas origens numa concepção do homem: os homens em grande parte são interdependentes e a atividade de nenhum homem é tão completamente privada, que nunca venha a obstruir a vida dos outros de uma forma ou outra - logo, a liberdade de alguns precisa depender da limitação de outros. Mas, colocar

\footnotetext{
${ }^{67}$. Não se trata de uma diferença entre a liberdade dos antigos e dos modernos, como colocada por Benjamin Constant, mas da mesma liberdade, a liberdade de não ser oprimido. Também não é o caso de pensar como liberdade negativa como coloca Isaiah Berlin. Como se perceberá mais à frente, há uma opressão seríssima e pouco abordada que advém de ignorância e do medo, própria daqueles que Kant chama de "menores".
} 
limites à liberdade não é descaracterizá-la? O que é a liberdade para aqueles que não podem dela usufruir? Sem as condições adequadas para o uso da liberdade, qual é o seu valor?

Ora, aquilo que em todos os tempos tão fortemente agarrou os corações dos homens à liberdade é a sua própria atração, seu encanto, independentemente de sua dádiva; é o prazer de poder falar, agir, respirar sem constrangimento, sob o único governo de suas próprias leis: ser verdadeiramente livre é poder. Quando posso fzer o que quero, eis a minha liberdade; mas só quando quero sinceramente aquilo que quero, já que a liberdade não é apenas um poder sobre si, mas um poder sobre todos e sobre tudo mais, pois que dessa liberdade brota todo artificialismo da vida humana.

Assim, até o momento, a palavra liberdade adquiriu três sentidos: 1) liberdade política - participação dos homens na escolha do seu governo, no processo legislativo e no controle da administração, assim como limitação no poder coercitivo do Estado; 2) liberdade interior - à medida em que as ações de uma pessoa são guiadas pela sua própria e ponderada vontade, e não por circunstâncias ou impulsos momentâneos, ou por mera reação; 3) liberdade como poder - ao poder de satisfazer os desejos à medida da escolha de alternativas que são oferecidas ou inventadas, descobertas, criadas. Essas liberdades são as condições para um tipo de "liberdade individual" moderna: um tipo de liberdade espiritual que implica na ausência de obstáculos a possíveis escolhas e atividades do homem. Uma liberdade decorrente de uma necessidade espontânea, que brota da essência do próprio ser humano, uma capacidade de produzir, enquanto causa, certo tipo de efeito.

A extensão da liberdade social ou política consiste na ausência de obstáculos, não simplesmente as escolhas reais, mas também as escolhas potenciais - ao modo de agir de uma forma ou de outra, conforme a opção. Assim, entendo a liberdade individual como uma espécie de triunfo da individualidade, tanto sobre a autoridade que pretende governar pelo despotismo, quanto sobre as massas, que reclamam o direito de subjugar a minoria: é a capacidade de dar início, no espaço público da palavra e da ação, às coisas novas, singulares e sem precedentes.

A liberdade individual é antes de tudo um ato contra a sujeição: permite procurar descobrir a verdade ou aperfeiçoar um certo tipo de caráter - crítico, original, imaginativo, independente, não conformista até o nível da excentricidade etc. - pois que a verdade só pode ser achada e tal caráter só pode ser aperfeiçoado em condições de liberdade. O desejo 
de não sofrer imposições, de ser deixado a sós, tem uma característica de alta civilização, tanto por parte de indivíduos quanto por parte de comunidades. Alguém capaz de fazer decidindo, sem que decidam por ele, se autoconduzindo e não sofrendo influências de natureza externa ou de outros homens como se fosse uma coisa ou um animal, um escravo incapaz - e de conceber metas e diretrizes inteiramente suas, e de concretizá-las, desfruta de liberdade individual.

Fundamentalmente essa liberdade permite ser cônscio de si mesmo, como um ser que pensa, deseja e age, assumindo a responsabilidade por suas opções e sendo capaz de explicá-las mediante referências a suas próprias idéias e a seus próprios objetivos. A liberdade individual é rigorosamente liberação ${ }^{68}$. E com certeza a liberdade individual não é uma necessidade primária para todo mundo, pois não há ausência de frustração ao exercêla, mas somente o mínimo de liberdade de que se precisa e que se pode vir a precisar amanhã, sem certeza de atingir a felicidade.

Naturalmente que a liberdade tem várias facetas; ao consultar qualquer biblioteca de filosofia percebe-se a infinidade de possibilidades para abordar o problema, a solução, a questão, o bem, o dom, a virtude e muito mais que os autores disseram que a liberdade é ou deve ser. Porém, concordando com Hannah Arendt, o lado mais significativo da liberdade é a liberdade política, não apenas como um campo conceitual, mas antes de tudo como um fato da vida cotidiana, decorrente da possibilidade de ação entre os homens. Só onde há vida política há liberdade, e só onde há liberdade há vida política propriamente dita: a política e a liberdade têm uma origem comum, são um mesmo processo inseparável ${ }^{69}$.

$\operatorname{Arendt}^{70}$ afirma: "Os homens são livres - diferentemente de possuírem o dom da liberdade - enquanto agem, nem antes, nem depois; pois ser livre e agir são uma mesma

\footnotetext{
68. A liberdade é sempre uma atribuição de responsabilidade que pressupõe a capacidade da ação racional, uma certa capacidade mínima de aprendizado e previsão, de orientar-se pelo conhecimento das conseqüências dos atos que pratica. Não se justifica a liberdade em si mesma, como um valor último, sem que a justificação esteja pragmaticamente - pelos seus frutos - exposta. Do que se conclui que a liberdade individual mesmo desejada por todos, poucos de fato conseguem exercer em sua plenitude. Infelizmente, essa liberdade individual tem gerado mais individualismos e/ou egoísmos que individualidades livres e autônomas: exercer a liberdade individual significa ao mesmo tempo não estar sujeito às necessidades da vida nem ao comando de outro e também não comandar e nem desejar comandar nada nem ninguém. Não significa submissão, como também não significa domínio, mas antes auto-domínio e auto-submissão.

69. "Sem um âmbito público politicamente assegurado, falta à liberdade o espaço concreto onde aparecer..... A liberdade como fato demonstrável e a política coincidem e são relacionadas uma à outra como dois lados da mesma matéria". Arendt, O Que é liberdade? p. 195, in Entre o Passado e o Futuro.

${ }^{70}$. na p. 199 em $\underline{\text { que é liberdade? }}$
} 
coisa". O nascimento de novos indivíduos no mundo inaugura novas ações, ou pelo menos tem essa possibilidade: se irá agir ou poder agir é algo em grande parte decorrente de contingências externas, mas a potencialidade para a ação está no homem ${ }^{71}$. Desse fundo de realidade política que é possível avistar ${ }^{72}$, regido pelas relações de causalidade e sobre o qual os atos livres destacam se da massa enorme de ocorrências diárias, é que podemos reconhecer uma ação livre, transformando o curso dos acontecimentos naturais, assim como distinguir graus ${ }^{73}$ de liberdade em função do modo de transformação dessa realidade.

As instituições representativas do mundo contemporâneo proporcionam uma medida considerável de liberdade de palavra e pensamento, mas a espécie de liberdade que possibilitam tem pouco valor, já que não abre os canais que levam à ação, ao significativo exercício da liberdade. Essa liberdade representa uma série de salvaguardas puramente negativas, necessárias para proteger a vida dos trabalhadores, proprietários, desempregados, diversas etnias, defendê-los dos abusos do governo ou dos mais fortes. Porém, essa liberdade que deixa os homens apenas na esfera privada, com toda a futilidade que esta comporta, dificulta o desenvolvimento da cidadania consciente e do exercício político.

Naturalmente, o eleitor pode influir sobre seus representantes por intermédio de partidos e grupos de pressão, mas somente no que se refere aos seus interesses e bem-estar. E como o interesse é um assunto puramente privado, torna difícil o bem comum ou algum tipo de republicanismo emergir dessa liberdade. Alguns possuem um império tão absoluto e tão irresistível em sua propriedade ou vida particular, que preferem de certo modo renunciar a seus direitos de cidadão e da sua qualidade de homem público, para não se apartar do caminho que traçaram.

Não obstante, quando tratamos das relações entre política e liberdade, ou quando nos perguntamos se em tal país se é livre, ou quando invocamos as liberdades políticas como as liberdades fundamentais, ou ainda quando dizemos que um homem é livre (por

\footnotetext{
71. Interessante notar que o ato de nascer não decorre de uma escolha livre dos indivíduos, mas a partir do nascimento há possibilidade de seguir trajetórias que decorrem da criatividade individual e coletiva e não apenas das contingências externas.

72. Na política contemporânea há um teor de ocultamento enorme. Jamais desapareceu essa prática, seja através da construção dos "direitos" de segredo de Estado, seja através da influência que o poder público pode exercer sobre a imprensa, através da monopolização dos meios de comunicação de massa, sobretudo através do exercício do poder ideológico, forma pública e lícita da "nobre mentira" de origem platônica ou da "mentira lícita" dos teóricos da razão de Estado.

${ }^{73}$. Não é que somos mais ou menos livres, mas o modo e o fim de exercer a liberdade reflete quando se atinge ou não níveis éticos nas escolhas, e podemos assim determinar formas éticas no seu exercício.
} 
oposição a um escravo ou a um preso), referimo-nos ao que se pode chamar liberdade de direito, isto é, a ausência de coerções externas - as interdições e as obrigações - nascidas do Estado, de uma coletividade, da sociedade ou mesmo de uma pessoa. Há um segundo sentido que se pode chamar liberdade de fato, por oposição à de direito: não se trata de perguntar se é permitido fazer, dizer, pensar etc., mas sim, se é possível fazer, pensar, querer etc. Não nos referimos mais à ausência de coerções das leis civis, das obrigações sociais, das regras coletiv as, das interdições, mas às intrínsecas - aquelas que concernem ao próprio sujeito. Pode muito bem existir liberdade formal - ter o direito de fazer - sem existir uma liberdade material ou espiritual, ou seja, sem ter meios de realizar.

Logo, é preciso que seja realmente eu quem age, e não tudo aquilo que pôde forjar meu caráter passado e determinar meus pensamentos e atitudes presentes. É preciso que não apenas seja livre em relação às coerções externas, que meu entendimento seja livre em relação às minhas paixões, mas que minha vontade seja ela própria livre em suas escolhas e que não dependa do que sou como uma essência aparentemente fixa de tudo aquilo que me determinou a ser esta pessoa. A liberdade não deixa de ser também a relação de uma pessoa consigo mesma; a ausência de liberdade, ao contrário, seria a falta de relação de uma pessoa consigo mesma, por força da sua interação com outras coisas ou dependência de outras pessoas.

Se minha liberdade pode consistir de coisas banais como andar quando quero andar, desde que não esteja impedido por alguma doença, mais que tudo ela consiste em não fazer uma ação má quando se apresenta na minha consciência como má, mesmo ordenado por uma lei ou um superior; em subjugar um impulso quando a consciência faz me senti lo como perigoso ou danoso a um outro. Os homens podem crer que são livres, podem jactarse de que são livres e serem em realidade livres apenas no sentido negativo, e seguir sendo escravo no aspecto decisivo, de ser incapaz de aproveitar devidamente a liberdade que receberam. São escravos se são ignorantes do justo e do injusto, ou se crêem que o poder consiste na violência, ou a dignidade no orgulho e na soberba, ou se falta coragem ou possui preguiça para agir.

Entretanto, a liberdade moderna implica em lei e regras que emanam do corpo político e que definem para todos o necessário e o impossível, o obrigatório e o interdito, todas elas destinadas a garantir uma igual liberdade a todos. O Estado é o depositário fiel 
dos instrumentos coercitivos para que a lei e as regras sejam efetivadas na prática, garantindo a todos a igualdade de possibilidade no exercício de sua liberdade. A liberdade política não pode ser ilimitada, porque acarretaria uma situação em que todos os homens podem ilimitadamente interferir na atuação de todos os outros, e esse tipo de liberdade natural hobbeseana leva ao caos social, onde as necessidades mínimas dos homens podem não ser satisfeitas ou, então, as liberdades dos fracos podem ser suprimidas pelos fortes.

Faz-se assim necessário restringir a liberdade em favor de outros valores e mesmo da própria liberdade, na presunção que a área de livre ação dos homens deve ser limitada pela lei, seguindo daí a necessidade de traçar uma fronteira entre a área privada, estatal e a pública. Pensar a liberdade como ausência de dominação particular tem como implicação prática o reconhecimento do papel essencial do Estado como criador e fiador dos direitos dos cidadãos. O poder do Estado cria a igualdade e reduz o mais possível a dependência particular dos mais fracos aos mais poderosos. O Estado é chamado a modelar e a enquadrar as atividades privadas, de maneira a instaurar uma certa igualdade de oportunidades.

Nem ter a liberdade institucionalizada é o único objetivo do homem, nem a liberdade política é simplesmente a área em que um homem pode agir sem sofrer a obstrução dos outros. Um homem não possui liberdade política, individual ou institucional, apenas se não estiver sendo impedido de atingir uma determinada meta por outros seres humanos. A simples incapacidade de atingir essa meta não constitui falta de liberdade política. O conceito de liberdade sob a lei repousa no fato de que, quando se obedece a lei, que são regras gerais abstratas decretadas, independentemente da sua aplicação ao nosso caso particular, não se está submetido à vontade de outra pessoa, mas a uma vontade coletiva da qual faz parte, sendo, portanto, livre ${ }^{74}$.

Entretanto, nem a autoridade da lei, nem a força dos Estados servem de garantia que não seremos usurpados da liberdade, porque a desobediência é também um produto da liberdade, e essa desobediência pode se dar de muitas maneiras, desde uma dissidência política legítima no seio social até práticas individuais de violência, crueldade e perversidade. As pessoas são as partes do pacto social, cada um convindo com todos os demais em criar a sociedade e o Estado. O poder supremo de conservar-se a si mesmo e a

\footnotetext{
${ }^{74}$. Como bem salientou Rousseau no Contrato Social.
} 
sociedade permanece sempre nas pessoas mesmas: solitários, mas não sozinhos! Não podem renunciar a esse poder. Nenhum homem ou sociedade de homens tem poder de renunciar a sua própria conservação ou aos meios para consegui la, assim como não podem renunciar a liberdade de escolha, ou como diz Sartre, a pessoa está condenada a escolher! A força do governo unicamente deve opor-se à força injusta ou ilegal da parte das pessoas ou dos seus negócios. Resistir não é um direito político, se trata de um direito natural que não se exerce enquanto opera um governo devidamente constituído.

A inexistência de um espaço público real de comunicação intersubjetiva, individualizada e livre transforma o juízo próprio no último recurso para poder se movimentar no mundo de forma livre. Sem o espaço público garantido, o juízo é o que resta para garantir a independência mínima capaz de prevenir ou identificar coisas fictícias, ações provocadoras e predadoras do diferente, assim como os demais riscos elementares da vida diária. Disso decorre muita impotência pessoal e coletiva, e a impotência é uma grande geradora de violência. Com o esvanecimento contemporâneo do poder e da autoridade, torna-se uma tentação substituŕ los pela violência.

(2)

Modernamente, por violência entende-se a intervenção física de um indivíduo ou grupo contra outro indivíduo ou grupo (ou também contra si mesmo). Para que haja violência é preciso que a intervenção física seja voluntária. A intervenção física, na qual a violência consiste, tem por finalidade destruir, ofender, coagir e, no limite, matar. Para ser considerada violência uma ação deve ser exercida contra a vontade de um outro que se torna vítima. O objetivo óbvio e direto do emprego da violência é destruir os adversários ou colocá- los na impossibilidade física ou moral de agir com eficácia.

A violência pode ser direta ou indireta. É direta quando atinge de maneira imediata o corpo de quem sofre. É indireta quando opera através de uma alteração de ambiente físico ou moral, no qual a vítima se encontra ou através da destruição, da danificação ou da subtração dos recursos materiais, ou pela ofensa e até mesmo pela indiferença. Se, por vezes, a violência pode ser utilizada como sinônimo de força, por outro lado distingue-se muito da noção de poder. O poder é a modificação da conduta do indivíduo ou grupo, dotada de um mínimo de vontade própria. A violência é a alteração danosa do estado dos indivíduos ou grupos, não importando que seja realizada de forma física ou moral. O poder 
muda a vontade do outro; a violência, o estado do corpo ou de suas possibilidades ambientais e instrumentais. Com o poder, ou seja, intervindo sobre a vontade do outro, pode-se obter, em hipótese, qualquer conduta externa ou interna, tanto uma ação como uma omissão, tanto um acreditar como um desacreditar. Com a violência pode-se obter uma omissão: imobilizando ou prendendo a vítima pode-se impedila de realizar qualquer ação socialmente relevante, mas alterando o estado físico do outro não se pode obrigá-lo a fazer nada socialmente relevante. Via de regra, a violência aparece exatamente quando desaparece o poder, seja o individual, o social ou político, quando diante da impotência para agir, reage-se bruscamente.

A violência não é um fenômeno novo nas relações humanas, ainda que seja novo o lugar que ocupa nos estudos contemporâneos, adquirindo o status de temática relevante nas ciências sociais. É lugar comum considerar que o fato se deve à violência estar num crescendo no mundo moderno, o que exige estudos aprofundados para tentar frear algo que é tratado como uma espécie de anomalia social, uma patologia que está a exigir um tratamento drástico por especialistas e instituições ${ }^{75}$. No entanto, a violência sendo um fenômeno natural, isto é, uma manifestação do processo vital, pertence ao âmbito político dos negócios humanos, cuja qualidade essencialmente humana é a faculdade do homem para agir, a habilidade para começar algo novo. O novo não necessariamente é algo bom. E a violência quando não inicia reações, inibe ações ou reações.

O que se entende por violência vem sendo alterado através dos séculos. Muitas das relações humanas classificadas hoje como violentas, foram no passado consideradas atitudes normais e até civilizadas. Até pouco tempo atrás um pai bater num filho era normal e saudável, era para o bem da criança; hoje é considerado um ato de violência no mundo ocidental. Neste sentido, não se pode considerar que há um aumento da violência nos dias

\footnotetext{
75. Muitos estudos a respeito da violência, abordam-na como se fosse uma doença num organismo que necessita de intervenções cirúrgicas meticulosas, para extirpar um cancro social, que tira a paz dos homens e transmite uma doença contagiosa, que se não for contida a tempo, pode levar a morte do organismo. Tais metáforas biológicas tão usuais nos estudos sociais parecem mais obscurecer o problema, do que evidenciar o lado humano, ou melhor, político, onde a violência é mais um efeito e um instrumento facilmente justificável, mais do que algo em si mesmo, que tenha causa própria e existência independente das relações humanas. São também metáforas enganadoras as comparações entre organismos vivos/sociais e coisas construídas artificialmente pelo gênio humano. O desenvolvimento de um organismo é um processo dinâmico, sem equivalente nas nossas construções artificiais. Um embrião humano de seis meses tem inteiramente forma humana, embora seja menor que um homem adulto. Não se constrói uma casa fazendo crescer uma casinhafeto com a forma da casa determinada. Não existe uma planta de um organismo.
} 
atuais. E isso não só porque o que se considera violência sempre é relativo em cada época, em cada lugar e até mesmo em cada pessoa, como a forma de levantar os dados sobre a violência usa metodologias, variáveis e pontuações muito distintas, dependendo da época e do lugar, o que torna precipitado afirmar aumento ou diminuição de violência.

$\mathrm{Na}$ verdade, principalmente no Brasil, quando se fala que está aumentando a violência, refere-se à criminalidade, que, sem dúvida, não deixa de ser uma forma de violência, e que sem dúvida está aumentando. Não obstante, não é impossível ocorrer o aumento da criminalidade, mas por outro lado, pode estar havendo diminuição na violência. Supondo que deixar crianças fora da escola, pessoas sem aposentadoria, sem hospitais, ou seja, desassistidas pelo Estado, seja considerado violência, pode-se supor que as pessoas estão sofrendo menos violência hoje do que em décadas passadas, ainda que corram mais riscos de serem assaltadas. Todos os crimes são violentos porque são violações da lei, portanto, são condenáveis porque trazem conseqüências funestas ou desagradáveis, logo dignos de repreensão. Mas, a própria lei pode ser uma violência e, não seria a punição ou o castigo um tipo de violência, mais próximo da vingança do que da justiça?

Entretanto, a atitude violenta que existe dentro de comunidades políticas ou entre elas, decorre de se romper normas estabelecidas em comum, e para o bem comum, para benefício próprio através do prejuízo alheio. Ou seja, a violência só existe entre os homens que arbitrariamente, em nome do benefício próprio e através do prejuízo do outro ou outros, rompem os acordos da convivência pacífica do mundo das trocas. Aqui não interessa que seja decorrente de fatores patológicos, psicológicos ou socioeconômicos, o que é preciso atentar é o fato que é eminentemente um fenômeno político, decorrente da convivência social e das relações humanas.

E nesse contexto, violência não pode ser utilizada como sinônimo de força. As ações policiais ou jurídicas, quando pautadas nas leis, não são violentas, ainda que possam ameaçar, coagir ou mesmo matar a vida de alguém, e são empregadas exatamente para tentar deter a violência que uma pessoa ou grupo de pessoas realiza ao ameaçar, coagir ou matar alguém ou várias pessoas. Ainda que os atos possam ser semelhantes, as finalidades 
são distintas; uns realizam em nome próprio e para si próprio, em prejuízo do outro ou outros, os outros em nome de todos por determinação de todos e em benefício da maioria ${ }^{76}$.

É possível fazer uma ponte entre o aumento da violência e a crescente alienação da política na contemporaneidade. A violência parece estar se tornando uma prática governamental, mas só é diretamente sofrida por aqueles que entram em confronto com as forças políticas consolidadas, que hoje em dia são poucos. A violência do mundo contemporâneo tem peculiaridades que a distingue de épocas anteriores, ainda que seja uma constante histórica, pois tem migrado do uso da força física, para manipulação e coação das pessoas por instrumentos burocráticos ou ideológicos, que são mais sutis, mas não menos cruéis.

Ora, constata-se um crescente exercício de liberdades e de libertação por partes cada vez maiores da população mundial. Individual ou coletivamente as pessoas estão se emancipando umas das outras, das instituições, dos valores, das autoridades, dos governantes, da família, dos laços afetivos, das tradições, hábitos, de tudo. Além do excesso de escolhas para todos e o fácil acesso às mesmas, os compromissos entre as pessoas são quase sempre temporários, momentâneos e não vigorosos ou rigorosos. É uma liberdade que beira a solidão, tangencia o egoísmo, e navega com ventos rápidos para o isolamento de um individualismo imedia tista.

Todavia, em função do decréscimo das autoridades no âmbito religioso, filosófico, científico, político ou familiar, hoje é ameaçadora a possibilidade de autoritarismos de maiorias sobre minorias, de minorias sobre grupos, de grupos sobre pessoas e de indivíduo sobre outro, assim como também existe a possibilidade de querer impor a vontade própria a todos por fanatismos, fundamentalismos, individualismos. Não há limites para nossas ações, logo, não há limite para a violência também. Naturalmente, o problema não é que somos mais violentos hoje do que éramos no passado; sob muitos aspectos acredito que não, somos mais civilizados, com hábitos mais amenos e neste aspecto, menos violentos. $\mathrm{O}$ grande problema é a quantidade de recursos de que se dispõe hoje para exercer a violência: os artifícios tecnológicos construídos pelos homens do último século nos colocam em risco

\footnotetext{
${ }^{76}$. A polícia só é violenta quando abusa da prerrogativa do uso legítimo da força, pois nesse caso é ela quem está rompendo com a ordem social ou o bem comum, e, portanto, agindo de forma ilícita, violando as normas jurídicas. Percebe-se o quão frágil é essa distinção e como se pode a qualquer momento sair para uma ação de força e acabar realizando uma ação violenta.
} 
em qualquer parte desse planeta. Mesmo sendo a violência um fenômeno de todas as épocas, a peculiaridade é que temos hoje pessoas com acesso a recursos quase ilimitados para criar armas ou instrumentos de destruição em massa. Também há acesso fácil a armas em qualquer parte do planeta como nunca se teve antes na história, e imensa maioria de pessoas sem virtudes cívicas ou humanísticas, mesmo que escolarizadas, com um fraco verniz cultural, desejosas, invejosas e liberadas de amarras morais e comportamentais do passado para buscarem realizar seus desejos até mesmo de forma imoral.

O homem não perdeu apenas certezas nas autoridades e nos governantes, mas também uma visão de futuro e adquiriu um aprisionamento no presente imediato. Ao perder a certeza de um mundo futuro que ultrapasse seus interesses imediatos, o homem é arremessado para dentro de si mesmo; tudo que pretende - e foi direcionado pelos interesses sociais e seus jogos - é retirar o máximo de prazer, sendo possível admitir que, a grande maioria, sem querer prejudicar ninguém.

A antiga autoridade que exigia respeito e resignação não tem força e vigor para persuadir ou se impor perante a pluralidade de interesses sociais diferenciados. Em seu lugar rege um autoritarismo burocrático e legalista que legitima comportamentos apenas pela lei. Nem pais, nem professores, nem sacerdotes, nem governantes conseguem a submissão (consentida ou não) das pessoas aos seus desígnios, tendo que utilizar força, quando não violência, geralmente legitimada em leis para "exercer o poder". A utilização da violência como recurso político tem se "legitimado" cada vez mais, abrindo-se mão da opção mais lenta da persuasão e debate de idéias, pela imposição de instrumentos aprovados por maiorias formadas e estabelecidas no momento.

A sensação de aumento da violência cotidiana na atualidade parece corresponder à máxima arendtiana: a violência existe onde não há poder. Não é a prática do poder político que resulta em violência, pelo contrário, ela é resultante da ausência de poder político. Aliás, de qualquer tipo de poder: a violência decorre da capacidade dos indivíduos de agirem fora de uma esfera de racionalidade social pré-estabelecida, e tem que matar o poder para ser exercida. A ausência do poder político nas diversas instâncias sociais, a inexistência de ações das autoridades no diversificado emaranhado das relações humanas atuais, são fatores relevantes para uma crescente onda de violência social. A violência como decorrência de ausência de poder deve ser entendido não apenas como uma espécie 
de prática política, mas também como decorrência do decréscimo da importância da política na vida contemporânea ${ }^{77}$, tanto pelo aspecto que a grandeza numérica das pessoas inviabiliza a participação política direta nos negócios públicos, como pelo desenraizamento social dos indivíduos atomizados, que desvinculados de qualquer tipo de organização pública - basta um vínculo com o Estado - tornam-se mais manipuláveis politicamente.

Fomos introduzidos na vida isolada de uma sociedade de massas solitárias, onde cada um vive só para si, temendo a todos como usurpadores potenciais de si ou das suas coisas. Confia-se apenas num círculo próximo, cúmplice e amigo, não necessariamente familiar. Diante da impotência cotidiana os indivíduos reagem - alguns com covardia, outros com indiferença, muitos com medo e outros ainda com violência - por não saberem agir. A ausência de ação demonstra que está desaparecendo os resquícios de política na sociedade, ou seja, a possibilidade de fala, organização e convivência voluntária entre os homens, fazendo que tudo, inclusive as mais simples relações humanas, até mesmo as familiares, perpasse pelo Estado onipotente e pela lógica de um processo em movimento, cujos assuntos, por se colocarem como sendo de natureza administrativa, técnicas ou científicas são resolvidos por especialistas.

No entanto, se acreditávamos num Estado benfeitor e pródigo, defrontamo-nos agora com uma burocracia, onde as lutas políticas não passam de brigas com funcionários cujo único objetivo é se ater a sistemas operacionais frios e calculistas, que apenas solicitam a nossa adequação às suas coordenadas. Reduzidos a um conjunto de números e documentos, existimos apenas quando conseguimos provar nossa existência digna ${ }^{78} \mathrm{e}$ temos ânimo para fazer valer os direitos. Pouca variedade há diante dos guichês governamentais, ainda que haja alternância nos governantes, sempre partidários das

\footnotetext{
77. Arendt, H. Sobre a Violência, p. 431994 - "Tem sido bastante afirmado que a impotência gera violência e, psicologicamente, isto é verdadeiro, ao menos para pessoas que possuam vigor natural, moral ou físico. Politicamente, o ponto é o de que com a perda do poder torna-se uma tentação substituí-lo pela violência..." 78 . Ora, existem inúmeras listas de maus cidadãos, maus pagadores, de criminosos, bandidos. É fácil detectar pessoas "más", há inúmeros instrumentos estatais e privados para isso. Essas pessoas "más", no entanto, são poucas perto da imensa maioria das pessoas, que se não são exatamente boas, são inofensivas e razoavelmente honestas e respeitosas com os demais. Em toda parte são solicitados documentos, atestados, certidões, são realizadas revistas nas nossas coisas procurando indícios de delitos e crimes. Em princípio, somos todos suspeitos e temos que constantemente ter que referendar nossa honestidade, nossa vida sem antecedentes criminais, provar que somos dignos. Há barreiras para todo lado exigindo R.G., CPF, passaporte, carteira de motorista, cartão de crédito. O mundo contemporâneo se dedica e aposta no lado negativo da humanidade, o que revela um certo realismo, mas negligencia um lado positivo e altruísta dos homens. Falta uma lista dos bons cidadãos!
} 
melhores das intenções, que findam sendo uma triste mesmice de má vontade e péssimos serviços. Na verdade, mais do que um interesseiro, o contemporâneo está se tornando um desinteressado. De forma egoísta, dispõe cada vez mais de mais potencial de ação, direcionando para só levar em conta seus direitos, suas vantagens, seus interesses, seus propósitos.

No entanto, se querem, senão eliminar a violência da vida social (o que, talvez, fosse até desumano e violento, para não dizer impossível), pelo menos ame nizá-la ou diminuí la, é preciso que não sejam violentos: aqueles que irão ao seu encontro devem caminhar no intuito de canalizar energias, não freá-las, e se possível nunca eliminá-las. Ora, o que desarma a violência não é uma contra-violência mais violenta e vigorosa, mas a coragem das pessoas em rechaçá-la, levando os "violentos" a se inibirem, diminuindo seu espaço de atuação, e se possível canalizarem essa energia para refletir sobre os sentimentos que fizeram ela surgir.

Não obstante, o que diminuiu significativamente a violência ou a brutalidade dos dias atuais é o que Norbert Elias denomina de "Processo Civilizador", mudanças de hábitos sociais que se dão num conjunto significativo de sociedades interligadas no decorrer de processos históricos de longo prazo, que levam gerações para se generalizarem e se adequarem às especificidades locais. Há um processo de abrandamento de hábitos, aumento de tolerância e respeito mútuo que ainda que não seja perfeito, resulta no que se poderia denominar de pessoas civilizadas, pessoas capazes de conviverem com diferenças culturais e de costumes, sem ofender e sem se sentir ofendido: um gentleman. Mesmo que um gentleman possa em algum momento ser violento, é de se supor que quanto mais gentlemen existirem, menos vioência ocorrerá nas relações humanas.

(3)

A liberdade é um poder ilimitado, nem tanto porque pode tudo, mas principalmente porque não se sabe o que ela pode originar. Seus aspectos positivos, mesmo quando pensada como liberdade negativa, apreciados e enaltecidos desde a Antigüidade, são bons motivos para se deter por algum tempo sobre ela. Entretanto, a positividade do instrumento depende da qualidade do sujeito, tanto que dela nasce a ética, assim como a violência, tidas como manifestações humanas por excelência. 
Não há violência pior ou melhor. Mas, um tipo específico de violência salientarse para aqueles que convivem com a política, seja atuando profissionalmente, seja militando em partidos e organizações políticas e sociais, seja academicamente: a corrupção. Que muitos possam considerar que a corrupção é um fenômeno eminentemente político, o fato é que ela um fenômeno social e sua prática significa, antes de tudo, um tipo de morte da política; ela é antes um grave fato político! Revela a esfera social sobrepujando a vida política.

A corrupção é um caso paradigmático de indignação moral generalizada: gera nas pessoas sentimentos de aversão ao fenômeno que as impede de perceber o fator político implicado em sua ocorrência, que ultrapassa em muito a mera ilegalidade ou ainda a imoralidade do ato em si. Juridicamente querem mudar as leis ou torná-las mais severas e punitivas para tentar inibir a ocorrência de corrupção. Condenações morais e legais produzem mais vinganças contra infratores do que justiça aos injustiçados ou impedimento de sua ocorrência.

Ora, por mais abominável que seja a corrupção do ponto de vista moral ou legal, pior é a decorrência política, social e econômica, pois não é um ato de um indivíduo contra outro, mas contra a totalidade, inclusive ele próprio enquanto membro de uma nação. Não é uma mera desonestidade ou furto, ou fraude, mas algo irreparável e irrecuperável: deixouse de realizar atividades públicas e sociais necessárias à sobrevivência humana para a satisfação de interesses particulares. Por mais privada que seja uma ação, numa República ela terá um resultado social e político multiplicador, seja para o bem de todos, seja contra todos, inclusive o próprio executor.

Entendo a corrupção como fenômeno pelo qual um particular, um político ou um funcionário do estado é levado a agir de modo diverso dos padrões normativos do sistema, favorecendo interesses particulares em troca de recompensa clandestina; pode ou não incorrer na tentativa de obtenção de um acesso privilegiado na estrutura do Estado, mas transcende a esfera do Estado e ocorre também entre os privados. Caracteriza-se por uma espécie de incapacidade de alguém dedicar suas energias ao bem comum e, paralelamente, uma tendência a colocar os próprios interesses acima dos da comunidade, gerando um processo da mais ínfima a mais alta camada social, que faz crescente a propensão dos poderosos a propor leis não para o bem das liberdades comuns, mas a fim de aumentar seu 
próprio poder. Sem dúvida, a corrupção é um tipo sério de inaptidão para a vida livre, pois que subjuga a vontade aos apetites imediatos dos desejos.

A corrupção como uma prática da recompensa escondida - um tipo de clandestinidade - é abordada distante do social e culpabilizada no indivíduo, na particularidade. Naturalmente há culpas pessoais, mas deve-se levar em conta as diferenças que existem entre práticas sociais e normas legais e a diversidade de avaliação dos comportamentos que se revelam no setor privado e estatal/público, pois a percepção da corrupção, como dos demais tipo de violência, varia no tempo e de lugar, até mesmo de pessoa para pessoa. Como não se tem um medidor preciso, apenas sensações e percepções, a corrupção é evidenciada e sensibilizada pelo período e o local em que se vive.

Há ainda um outro lado, a corrupção também serve como uma atividade alternativa da coerção. É uma forma particular de exercer influência, naturalmente ilícita, ilegal e ilegítima. Nesse caso, amolda-se ao funcionamento de um sistema, em particular, ao modo como se tomam as decisões. Diz respeito ao âmbito da institucionalização de certas práticas "heterodoxas"; relacionada com a cultura das elites e das massas, onde processos andam ou param com compras de funcionários, com amizades estratégicas, onde para se ter justiça atendimento nos serviços estatais - é preciso cometer injustiças. Naturalmente, a corrupção nunca se legitima por meio de uma afirmação de um suposto direito à oposição.

O nível de corrupção depende da probabilidade de êxito dessa prática, que é inversamente proporcional à elasticidade e vacuidade na formulação das normas, ou da sua interpretação. Ora, a corrupção pode ser usada para fazer valer a lei contra os transgressores com fins de fugir às sanções legalmente previstas, ocorrendo tanto no nível parlamentar, como no executivo, na magistratura e na burocracia. O fenômeno acentua-se com instituições que geram excesso de regulamentação e de centralização estatal, quando as instituições políticas não estão sob controle da maior parte da sociedade e com a existência de um sistema representativo imperfeito e com acesso discriminatório ao poder de decisão.

Por um lado, o uso em larga escala cria tensões no seio das elites, cujos confrontos levam aos desmascaramentos mútuos dos interesses opostos e conflitivos, gerando de tempos em tempos denúncias e "limpezas" entre os membros da elite. Muitos esquemas de corrupção caem por traições amorosas ou familiares, e outros motivos pessoais, mas como os corruptos competem por espaços, um espionando e vigiando o outro, delações acabam 
ocorrendo, nem tanto para purificar a política, mas para acabar com a carreira de inimigos políticos. Por outro lado, ainda que possa provocar reações ativas nas massas, como demonstrações e/ou manifestações de insatisfação e/ou indignação, finda por provocar mais reações passivas de apatia, alheamento e acomodamento com relação ao público e/ou político, o que proporciona tão somente a busca individual de sucesso.

Mas, com certeza a corrupção é fator de desagregação do sistema político: se momentaneamente funcional, por ser um tipo de paliativo ao Estado autoritário e burocrático, e suas ordens jurídicas e formais que impedem o desenvolvimento econômico individual e social, no longo prazo, será sempre negativa, pois acaba favorecendo alguma zona em prejuízo de todas as outras. A corrupção como um modo de influenciar nas decisões públicas, fere no íntimo o próprio sistema republicano, pois que desvia as instituições públicas e políticas para benefícios particulares e próprios. Este tipo privilegiado de influência, reservado àqueles que possuem meios, muitas vezes só financeiros, de exercê-la, conduz ao desgaste do mais importante dos recursos da vida política, sua legitimidade pela confiança mútua de uma honestidade recíproca.

Sendo a corrupção um fato político tem invariavelmente uma implicação social, tanto no aspecto cultural quanto no material. Quando cidadãos, políticos ou funcionários do Estado aceitam ou pagam suborno, se deixam corromper ou corrompem, eles não estão simplesmente tirando vantagem do cargo, furtando a população, enganando o contribuinte, fraudando o fisco, ou sendo imorais e antiéticos: estão traindo o cidadão! É um mal contra o bem comum que deve ser entendido de forma diferente do crime, daquele que atenta contra o bem particular ou daquele que pratica alguma desonestidade, porque ele é um desagregador do espaço público, tendo um efeito multiplicador do mal e divisor do bem em partes desiguais. A corrupção nega o modelo republicano na medida em que, exatamente onde o Estado deveria ser relevante, no estabelecimento de relações públicas entre agentes estatais e privados, cria relações pessoais e clandestinas.

Se for para ser tipificado como crime, a corrupção deveria estar enquadrada como crime político, como anti-republicanismo: ela nega a idéia de associação política para realizar o bem comum, criando a clandestinidade no público, encobrindo a convivência cínica de egoístas não assumidos, que exploram a fé pública. Entretanto, pensar como crime 
corre-se o risco de continuar a encobrir um problema de direito e de relações sociais, transferindo a corrupção para uma mera questão de atentado a propriedade, no caso, estatal.

Está cada vez mais aparente à sensibilidade comum, que a corrupção é um dos fatores responsáveis pela alocação ineficiente de recursos e pela deterioração da qualidade dos serviços públicos. A corrupção, além de desperdiçar recursos públicos, cria e alimenta incentivos errados para o direcionamento dos investimentos econômicos e sociais. É um meio financeiro de transformar relações impessoais em pessoais, visando à transferência de poder ou renda ilegal, imoral e injusta dentro da sociedade; visa à apropriação indevida de recursos, ou à garantia de tratamento diferenciado por parte das instituições públicas que deveriam primar pela igualdade de tratamento. Assim, a corrupção se torna fonte de toda sorte de desordens e de crimes quando falta habilidade e honestidade nas autoridades, nos planos políticos e em suas instituições públicas.

Ora, sem dúvida a corrupção é um custo que reduz a eficiência do investimento público; para cada real investido, parte significativa acaba desperdiçada, implicando na diminuição da eficácia dos investimentos ditos sociais, criando políticas deliberadas de ineficiência, ou simplesmente o puro desvio de verbas públicas destinadas para políticas de combate à pobreza, da melhoria da educação, da saúde, da segurança etc.; enfim, a corrupção é danosa tanto para o crescimento econômico, como para o desenvolvimento social e humano.

Salientamos ainda que a corrupção, por mais que venha acarretar custos para economia e para a sociedade, abala a credibilidade das instituições políticas. Impossível quantificar esses custos $^{79}$, pois que sua percepção ainda é recente e se dispõe de poucos instrumentos confiáveis para calcula-lo, na medida em que fica quase sempre sujeito à sensibilidade da imprensa e suas investigações de caráter mais emocional do que científico. Mesmo organismos sérios como a Transparência Internacional recebem severas críticas aos índices utilizados para "medir" a corrupção dos países ${ }^{80}$, por captarem mais percepções do que fatos propriamente ditos.

O maior impacto econômico da corrupção está no seu custo para o crescimento socioeconômico, acarretando em distorção no emprego da máquina pública, que deve ser

\footnotetext{
79 . Os Custos da Corrupção, Cadernos Adenauer, Corrupção e Desempenho Econômico, 2000, p. 63.

${ }^{80}$. Idem, Mensurando a Corrupção: uma revisão de dados provenientes de pesquisa empírica, p. 9.
} 
mantida em segredo, na clandestinidade, o que gera um custo adicional na sua obtenção ${ }^{81}$, cooptação e manutenção, através de uma rede de funcionários para a concretização de um esquema de corrupção, alocando-se recursos em atividades improdutivas, conseqüentemente, acarretando deformações de políticas sociais.

Não obstante os custos materiais elencados acima, pior são os custos culturais. O agravamento ocorre, sem dúvida alguma, com o surgimento de um círculo vicioso que gira ao redor de uma política de clientelismo, que não permite a emancipação da cidadania das massas. O inimigo da República é o uso privado/clandestino da coisa pública. É sua apropriação, como se fosse propriedade pessoal, o patrimonialismo, a apropriação privada da coisa pública, por políticos ou por quem tenha poder. O Estado é transformado em bem pessoal, patrimônio, e governantes de qualquer nível, do presidente ao simples funcionário, se valem do bem comum para sua vantagem privada.

A corrupção dos governos obedece a complexas séries de causas que podem se referir às modificações territoriais, mudanças econômicas, causas culturais, sociais, políticas etc. Porém, deve-se notar que muitas coisas tidas como corrupção hoje em dia, foi costume, ou melhor, fez- e faz! - parte da vida cultural do passado e do lugar. Além disso, nota-se, no decorrer da história, que quanto mais cultura cívica (aquela fundamentada nos conhecimentos dos direitos e deveres do cidadão), maior a sensibilidade para a percepção do fenômeno da corrupção e maior a disposição para o seu combate.

A busca do interesse privado moderno e não mais da virtude cívica favorece a corrupção, mas não é sua causa. Não se vence a corrupção simplesmente assegurando ${ }^{82} \mathrm{o}$ bom trato do dinheiro público. É preciso garantir o respeito ao outro, a qualquer outro. A questão da corrupção não se resolve com boa polícia fiscal, nem com instituições, se servidores, governantes, pessoas comum não forem republicanas. É na sociedade, mais do que no Estado, no sistema econômico ou no sistema político o ponto que devemos centrar a atenção da análise sobre a corrupção; aliás, é só a partir da sociedade que se entende o próprio Estado. Qualquer estudo teórico da corrupção, ou qualquer medida prática contra

\footnotetext{
81. Entre outras coisas, no caso brasileiro em particular, tem que se comprar cuecas enormes, além de malas e mais malas para carregar o dinheiro, e alugar jatos para transporta-lo, e funcionários para protege-lo, distribuílo, carrega-lo, etc. Afinal de contas, transferências eletrônicas de dinheiro, que seria gratuito, são facilmente rastreáveis.

${ }^{82}$. Como assegurar qualquer coisa sem pessoas seguras e confiáveis?
} 
ela exige vê-la e destrinchá-la nos costumes politizados na sociedade, pois o cerne da corrupção está na falta de virtude cívica.

Robert Putnam ${ }^{83}$ realizou um estudo sobre a experiência da descentralização política da Itália que se iniciou na década de 70 do século passado e foi até a década de 90. Após estudos e pesquisas (e convivência!) constatourse que o atraso do sul com relação ao norte da Itália advém não da centralização política anterior à reforma - como se acreditava e motivo pelo qual se tinha optado pela descentralização - mas de hábitos e costumes políticos seculares: após duas décadas a descentralização não diminuiu desigualdades sociais entre as regiões, nem aumentou a renda, nem ocorreu crescimento econômico maior no sul, e baixou pouco os índices de corrupção dessa região.

Ao contrário, por vezes as desigualdades aumentaram e o norte apresentou maior vigor econômico, tendo menor custo social e maior desenvolvimento humano. Disso, conclui Putnam, decorre que desenvolvimento social e econômico é um produto dos círculos, elos, ligações afetivas etc., virtuosos ou viciosos que se realiza numa comunidade política. Como tanto a reciprocidade e a confiança quanto a dependência e a exploração podem manter unida a sociedade, com diferentes níveis de eficiência e desempenho institucional, uma vez inseridos num desses dois contextos, os atores racionais têm motivos para agir conforme suas regras. A história determina qual desses dois equilíbrios estáveis irá caracterizar uma dada sociedade - por reagirem racionalmente ao contexto social que lhes foi legado pela história, os indivíduos acabam reforçando as patologias sociais subordinando-se à trajetória. Depois que o desenvolvimento toma determinado rumo, a cultura organizacional, os costumes e os modelos mentais do mundo social reforçam essa trajetória.

Putnam aponta para o fato que as instituições moldadas pela história independentemente de outros fatores que possa influenciar a sua forma, possuem inércia e robustez para se manterem inalteráveis. Corporificam trajetórias históricas e momentos decisivos, já que os modelos institucionais, como colocados, tendem a se auto-reforçarem, mesmo quando são socialmente ineficientes, pois é mais fácil para um indivíduo adaptar-se às regras do jogo vigentes do que tentar modificá-las. Assim, a cooperação e a colaboração ou a omissão e a exploração tornam-se entranhadas. As regras informais e a cultura não só

\footnotetext{
83. Comunidade e Democracia: a experiência da Itália Moderna.
} 
mudam mais lentamente do que as regras formais, como tendem a remodelá-las. Logo, o êxito ou fracasso das instituições políticas depende em grande parte do caráter dos cidadãos, de sua virtude cívica.

Segundo o autor, numa comunidade cívica a cidadania se caracteriza primeiramente pela participação nos negócios públicos. O interesse pelas questões públicas e a devoção às causas públicas são os principais sinais de virtude cívica. Decerto nem toda atividade política merece ser qualificada como virtuosa ou contribui para o bem geral, mas quando dotada de virtude cívica perde os aspectos nefastos que possui nas comunidades menos cívicas. O significado básico da existência de virtude cívica reside em reconhecimento e busca perseverante do bem público à custa de todo interesse puramente individual e particular.

Isso não significa que os cidadãos da comunidade cívica tenham que ser alt ruístas. Mas na comunidade cívica os cidadãos buscam o interesse próprio definido no contexto das necessidades públicas gerais (um interesse que é esclarecido e não míope), é sensível e tolerante com os interesses dos outros. Pode-se ser interesseiro sem ser corrupto, mesquinho e egoísta! Ora, os cidadãos de uma comunidade cívica não são santos abnegados, mas consideram o domínio público algo mais do que um campo de batalha para a afirmação do interesse pessoal. Na comunidade cívica, a cidadania implica direitos e deveres iguais para todos.

Tal comunidade se mantém unida por relações horizontais de reciprocidade e cooperação, e não por relações verticais de autoridade e dependência. Os cidadãos interagem como iguais, e não como patronos e clientes ou como governantes e requerentes. Os cidadãos virtuosos são prestativos, respeitosos e confiantes uns nos outros, mesmo quando divergem em relação a assuntos importantes. A comunidade cívica não está livre de conflitos, seus cidadãos podem ter opiniões firmes sobre as questões públicas, mas são tolerantes com seus oponentes.

A confiança mútua advinda das comunidades cívicas é o preceito ético fundamental que deve estar difundido entre as pessoas, caso se pretenda construir uma sociedade republicana. São as associações cívicas que incutem em seus membros hábitos de cooperação, solidariedade e espírito público. Somente as ações que os homens exercem uns sobre os outros renovam os sentimentos e as idéias, e promovem entendimentos. Os 
membros das associações têm mais consciência política, confiança social, participação política e competência cívica subjetiva. A participação em organizações cívicas desenvolve o espírito de cooperação e o senso de responsabilidade comum para com os empreendimentos coletivos. Além disso, quando os indivíduos pertencem a grupos heterogêneos com diferentes tipos de objetivos e membros, suas atitudes se tornam mais moderadas, em virtude da integração grupal e das múltiplas pressões.

Um conjunto de comunidades cívicas numa sociedade forma o que Putnam chama de "capital social" - confiança, normas e cadeias de relações sociais - que normalmente é um bem público, ao contrário do capital convencional, que é um bem privado. Por ser um atributo da estrutura social em que se insere o indivíduo, o captal social não é propriedade particular de nenhuma das pessoas que dele se beneficia. Assim como todos os bens públicos, o capital social costuma ser insuficientemente valorizado e suprido pelos agentes privados.

Naturalmente, a confiança necessária para fomentar a cooperação não é uma confiança cega. Implica uma previsão de comportamento de um ator racional independente. Você não confia em uma pessoa (ou uma entidade) que fará alguma coisa simplesmente porque ela disse que irá fazer. Você só confia porque, conhecendo a disposição dela, as alternativas de que dispõe e suas conseqüências, a capacidade dela e tudo mais, espera que ela preferirá agir assim. Ora, a cooperação voluntária depende do capital social. As regras de reciprocidade generalizada e os sis temas de participação cívica estimulam a cooperação e a confiança social porque reduzem os incentivos a transgredir, diminuem a incerteza e fornecem modelos para a cooperação futura. A própria confiança é uma propriedade do sistema social, tanto quanto um atributo social. Os indivíduos podem ser confiantes (e não simplesmente crédulos) por causa das normas e dos sistemas em que se inserem seus atos. Os estoques de capital social, como confiança, normas e sistemas de participação, tendem a ser cumulativos e a reforçar-se mutuamente, gerando os círculos virtuosos, que redundam em equilíbrios sociais com elevados níveis de cooperação, confiança, reciprocidade, civismo e bem-estar coletivo.

Nesse contexto, a corrupção como prática política corriqueira, constata-se apenas nas comunidades menos cívicas, onde há maior insegurança, os cidadãos são mais desconfiados, e as leis, mesmo que concebidas pelas maiorias, são feitas para ser 
desobedecidas. A vida coletiva nas regiões cívicas é facilitada pela expectativa de que os outros provavelmente seguirão as regras. Nas regiões menos cívicas quase todos esperam que os demais violem as regras. Parece que não há porque ser honesto numa sociedade desonesta. Parece tolice obedecer às regras do trânsito, às leis do fisco ou às normas previdenciárias, quando se espera que os demais venham a desobedecê-las também. Então, você também engana, e assim as cínicas e funestas expectativas de todos acabam se confirmando. Na verdade, as regras costumam induzir à formação de organizações e grupos interessados em suas imperfeições. Do ponto de vista do indivíduo, a coisa pública é problema dos outros. Os pequenos grupos de interesse não têm nenhum motivo para trabalhar pelo bem comum da sociedade e todos os motivos para engajar-se em atividades especulativas onerosas e ineficientes - lobbies para obter isenções fiscais, conluios para restringir a concorrência etc.

A baixa quantidade de capital social na comunidade não-cívica (ou menos) também é algo que tende a auto-reforçar-se. A deserção, a desconfiança, a omissão, a exploração, o isolamento, a desordem e a estagnação intensificam-se reciprocamente num miasma sufocante de círculos viciosos. O clientelismo e a afiliação partidária, e não a capacidade e a experiência, tornam-se os principais critérios para o provimento de cargos públicos. Os partidos vêem os novos governos como uma nova e lucrativa fonte de dinheiro e empregos. Na medida em que aumenta significativamente o número de cidadãos não virtuosos através dessas práticas de corrupção, diminui progressivamente a capacidade das sociedades para funcionar bem. A participação política é induzida pela prática do clientelismo personalista e não por compromissos programáticos com as questões públicas.

Os cidadãos têm contatos pessoais muito mais freqüentes com seus representantes do que os cidadãos onde há maior civismo, que estabelecem contratos. Porém, tais contatos envolvem principalmente assuntos pessoais, em vez de questões públicas de interesse geral. Esse contato particular não é determinado pelos fatores demográficos normalmente associados à educação, classe social, renda, engajamento político, partidarismo ou faixa etária, porém, é mais comum em todas as categorias sociais nas regiões menos cívicas, e a esmagadora maioria desses encontros envolve pedidos de emprego e "pistolão", pois as relações verticais de autoridade e dependência, tal como corporificadas no sistema clientelista, pessoalizam a política ou comercializam o público. A política é mais elitista. 
Assim, as relações de autoridade e corrupção na esfera política espelham fielmente as relações autoritárias e corruptas, num contexto social mais amplo. A elite é quase toda proveniente do segmento mais privilegiado da população. O típico membro da elite administrativa de comunid ades menos cívicas é essencialmente um burocrata clássico legalista, não-liberal, elitista, infenso aos métodos e práticas pluralista, fundamentalmente antidemocrático. Os cidadãos das regiões menos cívicas não são menos partidários nem menos politizados, mas a afiliação partidária e o engajamento político têm um significado distinto das regiões mais cívicas. Obter o favor dos poderosos é fundamental nas regiões menos cívicas; lá os contatos são cruciais para a sobrevivência, mais importante do que a prática política de participação cívica. Os contatos "melhores" são os verticais, de dependência e dominação, e não os horizontais, de colaboração e solidariedade.

A capacidade política está desenvolvida, porém, o indivíduo é ao mesmo tempo altamente politizado e resistente à associação na sociedade civil, pois todas as suas relações sociais são políticas ${ }^{84}$; contrariamente, na comunidade cívica não é o mero contato pessoal, mas o contrato social que sustenta a colaboração mútua: não é de cunho legal, mas sim ético. A sanção para quem transgride não é penal, mas a exclusão da rede de solidariedade e cooperação.

\section{2 -Uma Ética para a Cidadania}

O homem moderno se confronta com seu semelhante sem a proteção das condições pessoais que ostentava como diferenciadoras, com um novo conceito de igualdade que tornou difíceis as relações, pois lidamos com diferenças naturais (cor da pele, sexo, idade, conformação física, deficiências, "excluídos" de qualquer forma têm o apoio da opinião pública para garantir um tratamento compensatório), que nenhuma mudança política pode modificar. É pelo fato da igualdade exigir que se reconheça que todo e qualquer indivíduo é igual a outro que os conflitos entre grupos diferentes, que por motivos próprios relutam em reconhecer no outro essa igualdade básica, assumem formas tão terrivelmente cruéis.

\footnotetext{
${ }^{84}$. Ou seria melhor denominar de politiqueiras? As relações sociais são políticas, mais por serem partidárias e menos por serem públicas: não sendo republicano, não consegue ser um democrata.
} 
Mas, a vitória da igualdade moderna vem tornando a sociedade secretamente mais hierárquica, à medida que se torna externamente mais democrática. Introduz uma nova espécie de sentimento de pertencimento de um grupo, de uma crença, de uma nação, que consiste primordialmente no completo acobertamento dos defeitos de um grupo, de uma crença e de um povo e na ampla condenação dos que a eles não pertencem.

Ocorreu um abandono da crença na solidariedade humana, de classe, de categoria nos tempos modernos, em favor de novos tipos de imagens coletivas, baseadas na etnia, na região, em especificidades que não querem apenas se distinguir e garantir sua diferença, mas também se destacar, que é um sinal nítido do estreitamento do laço fraterno nos tempos atuais. A fraternidade se torna empatia para um grupo selecionado de pessoas, aliadas à rejeição daqueles que não estão dentro do círculo local ou pessoal. Esta rejeição cria exigências por autonomia em relação ao mundo exterior, por ser deixado em paz por ele, além, é claro, do respeito à sua singularidade, mais do que exigências para que o próprio mundo se transforme.

Houve a emergência de uma concepção moderna de liberdade, na qual o bem universal - dá lugar ao bom - particular - relativo a preferências e escolhas pessoais, conjugadas única e exclusivamente na primeira pessoa do singular: a área em que o homem aparentemente pode agir sem sofrer a obstrução dos outros. Esta liberdade, entendida negativamente como proteção contra a obstrução ou a coação, por meio da qual o indivíduo pode escolher aquilo que é bom para si e agir no sentido de materializar esta escolha, é assimilada a um catálogo de direitos formalizados e institucionalmente garantidos. A cidadania em sua forma moderna deixa de ter um traço marcadamente cívico, que relaciona à participação solidária na construção do bem comum, para ganhar a feição e ser entendida como titularidade de direitos.

Como resultado, originourse uma confusão entre vida pública e vida íntima: as pessoas tratam em termos de sentimentos pessoais os assuntos públicos, que somente poderiam ser adequadamente tratados por meio de códigos de significação impessoal. Poder-se-ia dizer que as pessoas estão perdendo a "vontade" de atuarem socialmente, ou que estão perdendo o "desejo" de agirem politicamente. O espaço público se tornou uma derivação do movimento. As ruas da cidade adquirem então uma função peculiar: permitir a movimentação das pessoas, mais do que encontros de cidadãos. 
O problema público da sociedade contemporânea torna-se duplo: o comportamento e as soluções que são impessoais não suscitam muita paixão; o comportamento e as soluções começam a provocar paixão quando as pessoas os tratam, falsamente, como se fossem questões pessoais. Mas, uma vez que este duplo problema público existe, ele cria um problema no interior da vida privada. Os sentimentos íntimos perdem suas fronteiras e querem aparecer na praça, serem aceitos; não se acham mais refreados por um mundo público onde as pessoas fazem investimento alternativo e balanceado de si mesma. $\mathrm{Na}$ verdade, a oposição entre público e privado fica problemática - porque o que será, então, o privado? Existirá mesmo uma dimensão interna, separada da externa? A diluição do abismo entre o público e o privado acarretou a naturalização generalizada da vida humana; é como se os homens só tivessem em comum as necessidades biológicas, psicológicas e os interesses econômicos.

Civilidade na vida moderna perdeu seu sentido antigo que a conectava com os deveres da cidadania; hoje significa mais saber refrear demonstrações públicas e políticas indecorosas e barulhentas. Civilidade é a atividade que protege as pessoas umas das outras e ainda assim permite que elas tirem proveito da companhia umas das outras. Tem como objetivo a proteção dos outros contra serem sobrecarregados por alguém. Cidade e civilidade têm uma raiz etimológica comum. Civilidade é tratar os outros como se fossem estranhos que forjam um laço social sobre uma distância social A cidade é esse estabelecimento humano no qual os estranhos devem e podem se encontrar.

É verdade que as pessoas que se encontram umas com as outras no mercado de trocas que se tornou a cidade, já não se encontram como pessoas, mas como donos de mercadorias e valores de troca. Numa sociedade na qual a troca de produtos é a principal atividade pública, os homens acabam rebaixados a mercadoria; esta degradação característica numa sociedade manufatureira julga os homens não como pessoas, mas como produtores, segundo a qualidade ou a quantidade de seus produtos.

Acrescentemos ainda o fato que há gerações as pessoas são instruídas em quase nada, senão em vários tipos de teoria social e política tendenciosa, ensinando uma lição acerca da manipulação (ou, antes, acerca de seus limites, que faríamos bem em não esquecer). Os homens podem ser manipulados por meio de coerção física, da tortura ou da fome, e suas opiniões podem formar-se arbitrariamente, em função da informação 
deliberada e organizadamente falsa, mas não através de persuasão oculta, tais como televisão, propaganda ou quaisquer outros meios psicológicos, pelo menos não em uma sociedade livre.

Infelizmente a refutação desta teoria conspiratória pela prática tem sido sempre, no melhor dos casos, uma tarefa precária e de longo prazo. O anúncio de algo fantástico tem sempre mais impacto que sua refutação metódica, sendo mais excitante que o exercício prosaico e sem glória da razão. Bastam duas palavras para dar vida a uma mentira, enquanto são necessárias longas considerações para explicar por que ela não é verdadeira. Os adeptos da manipulação, aqueles que a temem não menos indevidamente que aqueles que depositam sua esperança nela, dificilmente percebem a realidade das coisas. Assim, as pessoas e as suas singularidades acabam concebidas com estereótipos e estigmas culturais que só muita cultura antropológica e civilidade pode retirar.

Num mundo "incompreensível" e em perpétua mudança, as massas chegam a um ponto em que, ao mesmo tempo, acreditam em tudo e em nada, julgam que tudo é possível e que nada é verdadeiro. A propaganda de massa descobriu que o seu público está sempre disposto a ser enganado, uma vez que acha que toda afirmação, afinal de contas, não passa de mentira. Nossa sociedade imobilizou a temporalidade, já que é percebida como continuação do já feito, do ontem. Com esse tipo de apoio, com tais categorias sendo utilizadas para compreender a história (as de causalidade, finalidade, sucessão lógica), a sociedade se pensa na sucessão e nega-se enquanto autocriação.

É óbvio que a eficácia da propaganda da conspiração ou da existência de um suposto mal, evidencia uma das principais características das massas antigas e modernas, de todas as épocas. Não acreditam em nada visível, nem na realidade de sua própria existência; não confiam em seus olhos ou ouvidos, mas apenas na imaginação, que pode ser seduzida por qualquer coisa ao mesmo tempo universal e congruente em si. O que convence as massas não são os fatos, mesmo que sejam fatos inventados, mas apenas a coerência com o sistema do qual os fatos fazem parte. $\mathrm{O}$ que as massas se recusam a compreender é o fortuito de que a realidade é feita. Predispõem-se a todas as ideologias porque estas explicam os fatos como simples exemplos de leis que governam as coincidências, inventando uma onipotência que a tudo atinge e que supostamente está na origem de todo 
acaso. A propaganda prospera nesse clima de fuga da realidade para a ficção, da coincidência para a coerência.

O resultado natural da ficção conspiratória e fantástica é a não percepção que planos e ações, impulsos emocionais e racionais de pessoas isoladas constantemente se entrelaçam de modo amistoso ou hostil. Esse tecido básico, resultante de muitos planos e ações separados, pode dar origem a mudanças e modelos que nenhuma pessoa isolada planejou ou criou. Dessa interdependência de pessoas surge uma ordem irresistível e mais forte do que a vontade e a razão das pessoas isoladas que a compõem. É essa ordem de impulsos e anelos humanos entrelaçados, essa ordem social e massiva, que determina o curso da mudança histórica.

Entretanto, a sensação de conspiração origina a incivilidade da perversão da fraternidade na experiência comunal moderna. Quanto mais estreito for o escopo de uma comunidade formada por personalidade coletiva, mais destrutiva se torna a experiência do sentimento fraterno. Forasteiros, desconhecidos, "dessemelhantes", tornam-se criaturas a serem evitadas; os traços de personalidade compartilhados pela comunidade tornam-se cada vez mais exclusivos. O próprio ato de compartilhar se torna cada vez mais centralizado nas decisões sobre quem deve e quem não deve pertencer a ela: do ponto de vista da organização que funciona segundo o princípio de quem não está incluído está excluído, e quem não está comigo está contra mim, o mundo perde todas as nuances, diferenciações e aspectos pluralísticos - coisas que, afinal, se tornam confusas e insuportáveis para as massas que perderam o seu lugar e a sua orientação dentro dele. Lembremos que a mais importante qualidade negativa das massas é que nunca se detém a pensar no mundo como realmente ele é e jamais compara as mentiras com a realidade. Paralelamente, a sua virtude mais cultivada é a lealdade ao dogma ou ao líder, que, como um talismã, assegura a vitória final da mentira e da ficção sobre a verdade e a realidade.

Ora, mentiras e impostores sempre houve, entretanto o mundo contemporâneo é um verdadeiro Eldorado para ambos, porque, de um lado, uma notícia corre o mundo em segundos, encantando massas gigantescas pelo planeta, e, por outro lado, a triagem da informação e o julgamento crítico estão aqui desfavorecidos, por razões culturais profundas ligadas à maneira como o pensamento humano elabora o sentido. Digamos que aquilo que se chama de pensamento mágico e que permite a existência de coisas fantásticas como as 
conspirações, jamais desapareceu das culturas modernas ocidentais. O eterno retorno do místico nada mais é de fato que a manifestação recorrente de uma forma de pensamento que jamais nos abandonou.

O problema é que acabamos por ser hipnotizados por essas mensagens sem dimensão crítica. Uma forte esperança predomina sobre provas duvidosas; a influência dos preconceitos culturais cria uma preguiça científica e uma arte de acomodar os fatos faz com que prefiram modelar as coisas para ajustá-las à teoria que acreditam; certas práticas fazem obstáculo à revelação da verdade ao dirigir-se a uma audiência desprovida de cultura sobre a temática, o que impressiona a massa de incautos que admiram todos aqueles que falam de coisas que ela nada saberia dizer; tudo isso contribui para a criação ou recriação de mitos, conspirações, salvações milagrosas, pessoas carismáticas, sucessos e celebridades.

Entretanto, não deixa de ser paradoxal esse fenômeno. Ora, através de mudanças técnicas, tecnológicas, organizacionais e outras, a vulnerabilidade humana decresceu. $\mathrm{O}$ misterioso foi reduzido a ponto de haver pessoas que acreditam vir a ser um dia explicado. Por meio da melhora do nível de vida, dos seguros, do sucesso das explorações e descobertas, o ser humano ganhou confiança. Os riscos foram minimizados, os conflitos tornaram-se menos freqüente, padrões lógicos emergiram. O mundo mais asseado, sistemático e mercantil eliminou os demônios que haviam infestado o Ocidente. É como se existisse uma progressão natural da infância do mundo, em que os homens tinham medo do escuro, dos fantasmas e das bruxas, para sua bem mais prosaica fase adulta. Trata-se de um mundo cujos habitantes acreditam que, se soubesse o suficiente, tudo poderia ser explicado. A impressão predominante é a de um mundo secularizado, onde as pessoas estão prioritariamente preocupadas com dinheiro, o poder e as relações sociais. Não se trata, na medida do que nos é dado discernir até o momento, de um mundo toldado pelas sombras da ameaça do mal. Trata-se de um mundo curiosamente objetivo, o que revela uma aparente ausência, entre a população, da crença em indivíduos realmente perversos e satânicos.

E, no entanto, dentro do imaginário comum o mal subsiste e a sua essência reside (e resiste) numa combinação de diversas características. Em primeiro lugar, é algo sombrio, misterioso, oculto, escondido, não plenamente compreendido; daí uma associação com a noite, a escuridão, a cor preta, o secreto. Em segundo lugar, trata-se de uma força agressiva. O mal procura destruir a integridade, a felicidade e o bem-estar da sociedade "normal". 
Como a praga que dá na planta vai minando de maneira agressiva e até traiçoeira. Tais ataques são injustificados, ou carecem de motivo ou têm motivos perversos. O mal é uma inversão do bem, os padrões morais da sociedade sendo virados de cabeça para baixo. E segundo o senso comum é possível diagnosticar parcialmente a natureza de um mundo permeado pelo mal. Primeiro temos o segredo. As coisas não são o que parecem ser. Tratase de um mundo de inveja, "mautolhado", onde o bem é limitado. E como isso cresce num caldo cultural de conspiração herdado e cultivado! Do camponês ao cientista, poucos duvidavam da realidade diária do Mal, que há uma guerra santa sendo travada no decorrer dos séculos.

O Mal que subsiste, acreditam estar restrito às esferas das grandes corporações, dos monopólios, do "Império", dos organismos secretos, da política que têm o poder de manipular a todos, inacessível aos homens comuns, que pode no máximo cometer pecadilhos de menor importância. Sem dúvida, uma conclusão equivocada de premissas falsas.

Todavia, a palavra Mal/Mau ${ }^{85}$, em sentido forte, significa a antítese do bem/bom: moralmente depravado, mau, perverso, dado a vícios. Mau como criminoso, totalmente anti-social. Vida má ou desonesta. Praticantes de más ações. Ato mau ou desonesto. Pessoas más por não pagarem dívidas. Más inclinações e estreiteza de mente, má conversa. O mau como atos criminosos comuns e seculares. Cometer o mal é submeter a vontade às paixões. E na acepção fraca, adquire o significado de causar desconforto e/ou dor, ser desagradável, ofensivo e molesto, não ser "bom”, podendo ser usado em lugar de mau, desagradável, nocivo, ou ainda, não estar sadio.

\footnotetext{
85. Como nos diz Santo Agostinho no Livre Arbítrio, o mal não é um ser, mas deficiência e privação de ser, não existe mal no cosmos, mas apenas graus inferiores de ser; o mal depende de nossa má vontade e a má vontade não tem causa eficiente, e sim causa deficiente. Como existem muitos bens criados e finitos, a vontade pode vir a tender a eles, e subvertendo a ordem hierárquica, optando por bens inferiores, em vez dos superiores. Sendo assim o mal deriva do fato de que não há um único bem, e sim muitos bens, consistindo precisamente na escolha incorreta entre esses bens ou da sua dose. O homem é livre para fazer o bem e não é forçado a cometer o mal por nenhuma necessidade. Se o homem comete algum mal a culpa é sua. Sem o livre-arbítrio não haveria mérito nem demérito, glória nem vitupério, responsabilidade nem irresponsabilidade, virtude, nem vício. Esse poder de usar bem o livre-arbítrio é precisamente a liberdade. A possibilidade de fazer o mal é inseparável do livre-arbítrio, mas o poder de não faze-lo é a marca da liberdade.
} 
Ora, é crença antiga que todas as "más" ${ }^{86}$ ações são motivadas pelo impulso de conservação ou, mais exatamente, pelo propósito individual de buscar o prazer e evitar o desprazer; são, assim, motivadas, mas não são más em si mesmas: podem se tornar m relação com o outro. A triste verdade é que a maior parte do "mal" do mundo é feita por pessoas que nunca decidiram ser boas ou más, mas ao fazerem aquilo que acham certo, redunda em imensos males aos demais. As pessoas não são nem boas nem más, elas são simplesmente astutas. O problema é que os danos físicos, emocionais ou psíquicos para um indivíduo possuem variações, e não temos como saber se as ações irão causar ou não esses danos. Podemos estar causando danos a outrem ou a nós mesmos sem ter conhecimento algum disso.

Naturalmente, uma luta entre o prazer e o desprazer é insuficiente para explicar todas as ações equivocadas que os homens praticam uns contra os outros. O indivíduo quer para si o prazer ou quer afastar o desprazer; a questão é sempre, em qualquer sentido, a autoconservação. Nesse sentido, o que quer que o homem faça, ele sempre faz o bem, isto é, o que lhe parece bom ou útil segundo o grau de seu intelecto, segundo a eventual medida de sua racionalidade. Pode ocorrer maldade e ao mesmo tempo não ter por objetivo o sofrimento do outro em si, mas o próprio prazer, que pode se dar em forma de sentimento de vingança ou de uma mais forte excitação.

Não obstante, incorremos numa falácia perigosa quando da proposição - "Ninguém pratica o mal voluntariamente", se extrai a conclusão implícita: “Todo mundo quer fazer o bem". É claro que se restringirmos o bem, ao bem próprio, a conclusão se torna verdadeira. Mas se for o bem coletivo é preciso fazer avaliações e saber distinguir o bem particular do bem público. Mais ainda, e talvez impossível de realizar, saber o que é o bem!

$\mathrm{Na}$ verdade, são os graus da capacidade de julgamento que decidem o rumo em que alguém é levado por desejo, por violência, por direito ou por dever; toda sociedade, todo indivíduo guarda continuamente uma hierarquia de bens, segundo a qual determina suas ações e julga as dos outros. Mas ela muda continuamente; muitas ações são chamadas más

\footnotetext{
86. As aspas no mal é porque o termo tem forte ascendência cristã e lhe confere o peso do pecado. Seria preciso um termo mais imparcial para denotar aquelas ações que cometem o mal, mas não contem a intenção da maldade. Por exemplo, um viciado em jogo está fazendo um mal, mas não há maldade no seu ato, está apenas se divertindo ou sofrendo. A maldade não está no ato, mas na forma de encara-lo. O não desaparecimento do mal como conceito na Ética e Política, ou na linguagem ordinária é um dos mais extraordinários paradoxos da sociedade moderna. O fato de não ser mais possível conceber normalmente uma força abstrata do mal é sem dúvida de grande interesse para historiadores e antropólogos.
} 
e são apenas idiotas ou estúpidas, porque o grau de inteligência que se decidiu por elas era bastante baixo. E em determinado sentido todas as ações são ainda idiotas e estúpidas, pois o mais elevado grau de inteligência que pode hoje ser atingido será certamente ultrapassado: em todos os nossos atos e juízos parecerão, em retrospecto, tão limitados e precipitados como nos parecem hoje os atos e juízos de povos antigos e selvagens.

Assim, toda ação acarreta dificuldades diferenciadas, na medida em que ela é algo feito em comum por alguém singular, feita entre homens e para os homens, cabível de reação, de reação em cadeia e maciça. Há as conseqüências que são irreversíveis, outras que são imprevisíveis, pois toda ação desencadeia um processo, com a impossibilidade de desfazer o que se fez, embora não se soubesse nem se pudesse saber o que fazia ao exercer a faculdade de agir. $O$ fato é que as pessoas não sabem o que fazem: neste mundo, mais do que o mal existem equívocos, que são eventos cotidianos, decorrência natural do fato que a ação estabelece constantes relações inconscientes. $\mathrm{O}$ mal intencional é raro, mais até que as boas intenções.

Ora, a vingança ou a punição é o que, via de regra, atua como re-ação a uma suposta ofensa inicial: são reações automáticas à transgressão presumida na ação alheia, e que, dada à irreversibilidade do processo da ação, pode ser esperada e calculada. Nem a vingança, nem a punição levam a justiça, por mais justificável que sejam essas reações em certas circunstâncias, porque mais do que o certo, busca-se com elas uma compensação por um “mal” sofrido. É que pensar as ações apenas como boas ou más limita o alcance do entendimento, na medida que circunscreve as ações humanas numa lógica cujas premissas se baseiam na suposta veracidade que se deve presumir que há maldade nas intenções de todos.

A alternativa a vingança ou a punição é o ato de educar para que se tome consciência do erro cometido ou, como bem coloca Arendt na Condição Humana, perdoar, que jamais pode ser previsto e raramente é esperado; é uma reação que atua de modo inesperado, e embora seja reação, conserva algo do caráter original da ação. O perdão é a única reação que não re-age apenas, mas age de novo e inesperadamente, sem ser condicionada pelo ato que provocou e de cujas conseqüências liberta tanto o que perdoa quanto o que é perdoado. O perdão é a libertação dos grilhões da vingança, uma vez que esta prende executor e vítima no inexorável automatismo do processo da ação-reação que, 
por si, jamais chega necessariamente a um fim. Já a educação ${ }^{87}$ é um processo lento e nem sempre satisfatório, que só se impõe como alternativa quando as pessoas atingem uma mentalidade alargada e não visam mais apenas o imediato. Mas, tanto o perdão como a educação necessita de pessoas esclarecidas para que possam ocorrer.

As "más" ações que nos indignam baseiam se na crença de o homem que as comete tem livre-arbítrio, ou seja, de que dependeria do seu bel-prazer não nos fazer esse mal. Esta crença no bel-prazer suscita o ódio, o desejo de vingança, a perfídia, toda a deterioração da fantasia ressentida, ao passo que nos irritamos muito menos com um animal ou incapacitado, por considerá-los irresponsáveis. Causar sofrimento não pelo impulso de conservação, mas por represália - é conseqüência de um juízo errado, e por isso também inocente pela ignorância; não é uma atitude mentirosa, mas errada, falsa ${ }^{88}$.

Todos sabem, só cabe julgamentos onde há possibilidade de escolha, caso contrário nada se pode condenar ou enaltecer nas atitudes humanas. Quando não há ação no sentido forte, mas tão somente reação a ações alheias ou às contingências externas, o que sai do reino humano propriamente dito e nos lança numa espécie de vida natural, onde não há pecados nem perdão, reina absoluta a deusa fortuna. Posso falar do bem e do mal porque há uma possibilidade de escolha, o que só pode ser dito a respeito das ações humanas voluntárias e autônomas. Na medida em que não há liberdade, não pode haver julgamento das ações, pois não sendo decorrentes de atos livres, não podem ser ajuizadas em seu mérito.

Desse modo, a liberdade deve ser entendida como um problema ético, tanto quanto político; assim como pode gerar violência, pode gerar atitudes éticas. Ao entender a ação como uma atividade política por excelência a mesma se revela como produto e produtora dos destinos humanos com decorrências éticas, algo que se cria, não necessariamente de forma consciente, não como mero reflexo de necessidades, mas que espelha as questões que cada geração e local se coloca diante das ações que outras gerações e locais introduziram através de múltiplos fatores, nem todos eles determináveis.

\footnotetext{
87 . A educação será abordada no próximo item dessa parte.

${ }^{88}$. Lembremos que a verdade se contrapõe a mentira e a falsidade. Quando se contrapõe mentira e verdade, temos uma problema ético. Quando se contrapõe falsidade e verdade, temos um problema epistêmico. E um problema epistêmico pode sempre gerar um problema ético, por exemplo, achar que quem tem verruga no nariz é bruxo, e queimar pessoas com verrugas no nariz. Mas, aí não é mentira ou a maldade quem age, mas a ignorância.
} 
É verdade que os princípios éticos vêm sendo depreciados por homens astutos desde O Príncipe de Maquiavel, que são considerados por homens simples como coisas abstratas e inúteis. Mas, os princípios não são de modo algum teorias vãs, unicamente destinadas a serem debatidas nos obscuros redutos da academia. São verdades que se sustentam e que penetram gradualmente nas aplicações mais circunstanciais, até nos menores detalhes da vida social, se souber seguir seu encadeamento. É que a justificação de um princípio ético ${ }^{89}$ não se pode dar em termos de qualquer grupo parcial ou local, deve ser universal. Quando emitimos um juízo ético extrapolamos as nossas preferências e aversões, e exige-se que a ação humana para ser ética leve em conta seus prováveis efeitos, a responsabilidade e os princípios, e não apenas os fins.

As noções da ética não são adquiridas sem um processo de abstração, sem uma ruptura com o conhecimento intuitivo e imediato. Essa ruptura deve efetuar-se ao mesmo tempo no plano da representação mental, do conceito, e no da linguagem, das palavras e dos símbolos utilizados para exprimir o conceito. A virtude ética inclui a razão, mas não é algo essencialmente racional: é uma característica atitude ou disposição às emoções e as ações que dela derivam, onde a emoção encontra a racionalidade do seu agir entre os emocionais, que somos todos nós. Como a virtude deve ser escolhida per se, e não em vista a outros fins, e essa escolha não pode ser garantida como sendo a logicamente "melhor" ou que trará mais vantagem para o agente, só saindo do imediato e da visão de curto prazo e prolongando o olhar para o longo prazo, se percebe a validade ética do dever ser. Ora, o que é um dever? A idéia de dever é inseparável da idéia de direitos: um dever é o que, em um ser, corresponde aos direitos de um outro. Só onde não há direitos, não há deveres.

Uma vez que não há nada fixo no mundo dos homens, como salientado no começo, restam apenas as circunstâncias, e cada um é juiz das circunstâncias. É nesse sentido que uma formação ética se faz necessária no mundo atual, pois invariavelmente as normas legais estão aquém dos acontecimentos, e por vezes não dizem o que fazer ou que evitar.

\footnotetext{
89. Aristóteles diz na Política que chamamos aquilo que merece ser buscado em si mesmo mais absoluto do que aquilo que merece ser buscado com vistas em outra coisa, e aquilo que nunca é desejável no interesse de outra coisa mais absoluto do que as coisas desejáveis tanto em si mesmas como no interesse de uma terceira; por isso chamamos de absoluto e incondicional aquilo que é sempre desejável em si mesmo e nunca no interesse de outra coisa. Ora, esse é o conceito que fazemos da felicidade e da liberdade. São procuradas sempre por si mesma e nunca com vistas em outra coisa, ao passo que à honra, ao prazer nós de fato não escolhemos por si mesmos, mas no interesse da felicidade e da liberdade, pensando que a posse deles nos tornará felizes ou livres.
} 
Além disso, como cidadãos do mundo, precisamos de instrumento para agir num mundo globalizado e que transcenda o entendimento das leis locais, requisitando agora instrumentos que nos direcione para o universal. Tanto a ética quanto a razão exigem que nos ergamos acima do nosso ponto de vista particular e adotemos uma perspectiva a partir da qual a nossa própria identidade pessoal não é importante. Portanto, propõe que ajamos com base em juízos universais ou universalizáveis diante das circunstâncias cotidianas. Na ética há uma rejeição de um padrão moral absoluto em favor do tipo de julgamento ético situacional que varia de acordo com a pessoa e a circunstância, sendo a virtude assim uma questão de fazer a coisa adequada no momento certo.

Entendo por ética tanto uma ação como uma reflexão sobre a ação. Segundo Aristóteles, são de duas espécies a virtude ética, intelectual e prática, a primeira gera-se e cresce graças à aprendizagem e ao ensino; enquanto a virtude prática é adquirida como resultado do hábito. Não é por natureza, nem contrariando a natureza que as virtudes se geram em nós, somos adaptados por natureza a recebê-las e nos aperfeiçoamos pelo hábito. Primeiro adquirimos a potência e mais tarde exteriorizamos os atos, e tornamo-nos justos praticando atos justos, assim como as demais virtudes. São pelos atos praticados em nossas relações com os homens que nos tornamos justos ou injustos; pelo que fazemos em presença do perigo e pelo hábito do medo ou da ousadia, nos tornamos valentes ou covardes.

Classicamente a ética é uma espécie de ciência do que convém fazer; é a teoria dos deveres; depende do empírico porque visa situações concretas ligadas ao exercício de uma atividade e suas regras dizem respeito ao convívio do homem em grupo que as edita e que a ele mesmo se aplica. Sua natureza disciplinar deriva não de um caráter negativo, mas propositivo, ainda que suas propostas possam ser na maior parte das vezes se negar a realizar alguma coisa. Julga-se que é cunho característico de um homem dotado de ética poder deliberar bem sobre o que é bom e conveniente para ele, não sob um aspecto particular, mas sob àqueles que contribuem para a vida boa em geral. Num sentido geral, o homem que é capaz de deliberar possui algum tipo de ética ou sabedoria prática.

Mas, a ética enquanto uma sabedoria prática não pode ser ciência, nem arte, muito menos uma religião, restando ser ela uma capacidade verdadeira e raciocinada de agir com respeito às coisas que são boas ou más, justas ou injustas, certas ou erradas para o homem, 
versando sobre coisas humanas e coisas que podem ser objeto de deliberação. É uma virtude que forma opiniões nos homens (e dos homens!), mesmo que não possam praticálas: a opinião versa sobre o variável e a vida prática, campo por excelência da ética. Do ponto de vista ético, delibera bem no sentido irrestrito da palavra aquele que, baseando-se no cálculo, é capaz de visar o melhor, para o homem, das coisas alcançáveis pela ação. Lembremos que a ética não vem apenas do conhecimento, mas também da capacidade de agir, mas a capacidade de agir sempre é potencializada pela aquisição de conhecimento.

Está na essência da conduta ética que as ações da virtude sejam efetuadas por si mesmas e não por suas conseqüências, e pressupõe que o homem não é guiado em todas as suas ações por um cálculo de que a honra seja a melhor política ou de que cada ato virtuoso contribua a sua própria felicidade; as ações virtuosas devem ser efetuadas por si mesmas e não por suas conseqüências ${ }^{90}$. Não se pode levar as pessoas a agirem eticamente ao oferecer-lhes razões ligadas apenas ao interesse pessoal (mesmo sendo sempre do interesse pessoal delas), pois, se aceitarem o que dizemos e agirem conforme os interesses, estarão apenas agindo em função do interesse pessoal, e para ser ético exige-se que se ultrapasse um ponto de vista pessoal e que assuma um ponto de vista de um espectador imparcial.

O fato de ser difícil, por vezes impossível, atingir a imparcialidade, a busca em si mesma já é importante. Não se deve esperar perfeição, que se possa sempre ser justo e imparcial, mas pode-se esperar que se busque a justiça e a imparcialidade ao agir e pensar, pois, segundo Aristóteles, o exercício da virtude diz respeito aos meios. Por conseguinte, a virtude está em nosso poder, do mesmo modo que o vício, pois se depende de nós o agir, também depende o não agir; de modo que quando temos o poder de agir quando isso é nobre, também temos o de não agir quando é vil; e se está em nosso poder o não agir quando isso é nobre, também está o agir quando isso é vil. Logo, depende de nós praticar atos nobres ou vis, e é isso que se entende por ser bom ou mau, então, depende de nós sermos virtuosos ou viciosos.

\footnotetext{
90. Aristóteles distingue claramente entre o homem que realiza façanhas valorosas por si mesmas e o que só o faz pensando na opinião de seus concidadãos: distingue duas classes de homens virtuosos, o homem bom que atua com virtude por um desejo de adquirir as coisas $\mathrm{n}$ aturalmente boas da vida (riqueza e honras) e o homem nobre e bom que realiza ações de virtude por si mesmas ou porque são nobres, por saber que é o melhor a fazer. Como diz, todos os homens ou a maioria deseja o que é nobre, mas escolhem o que é vantajoso; ora, é nobre fazer bem a um outro sem visar a qualquer compensação, mas receber benefícios é que é vantajoso.
} 
Mas, é preciso fazer distinções entre ética e moral, com o intuito de superar os conflitos entre as diversas moralidades no interior das sociedades que possuem vida política. As diferenças são sutis, porém fundamentais para perceber que se está diante de fenômenos humanos, ainda que interligados, distintos. A moral é um produto dos costumes e visa regulamentar a vida do grupo que a compartilha, excluindo do seu convívio aqueles que dela não compartilham, a ética visa a busca de uma reflexão sobre as diversas moralidades, tentando atingir algum tipo de universalidade nas normas de convivência humana, onde as diversas moralidades consigam sobreviver sem lutas, sobreposições ou imposições. A moral é punitiva enquanto a ética é educativa; a moral é vingativa, buscando muitas vezes o fim daqueles que não a compartilham, ou pelo menos tenta evitar que as pessoas realizem vontades que estejam em desacordos com os seus preceitos, através de punições e/ou perseguições, desenvolvendo medos e temores; a ética visa atingir a justiça, ou seja, que cada um receba de acordo com as suas necessidades e vontades, não por obrigações, mas pelo entendimento, e que aprendam a verdade antes de se matar por ela. Enfim, a moralidade, está na esfera do particular, é algo a ser transcendido pela instituição de uma ética decorrente do debate político, só realizável na República que seja capaz de garantir a privacidade dos gostos e vontades diferenciadas, determinando o espaço para condutas comuns e o espaço para as condutas particulares.

$\mathrm{Na}$ ética temos balizas, mas não há proibições. A morte banal e cruel de outro homem é abominável eticamente, mas não é proibida. De que adianta proibir, pois que os homens sempre se matam e se mataram. Condenável eticamente, sem dúvida, porém, é moralmente que a pessoa é punida. A ética quer a verdade que advém de uma busca consciente do seu aperfeiçoamento, assim como o certo e o justo, que não estão estagnados, mas se modificam com novos conhecimentos, novas relações, alterando costumes e hábitos. Um comportamento ético é capaz de obstaculizar as nossas formas de agir, portanto, se não sabe o que nos dizer para fazer, pelo menos aponta quando parar, e saber o errado é tão importante quanto agir certo, o primeiro passo para um acerto futuro. Enquanto a moral quer seu dogma como verdade e pune tudo que considera errado, é legalista: tenta impedir qualquer novidade ou mudança.

Uma moral, de imediato, cria o seu contrário, uma imoralidade, que abrange tudo aquilo que não está prescrito por suas regras de conduta, até mesmo atividades que são 
amorais, ou seja, atividades independentes e que não visam romper ou transgredir a moralidade aceita por determinado grupo. A moral é mais do que prescritiva, é proibitiva, punitiva, caracterizando-se por uma negatividade e inúmeras interdições, e obriga a pessoa aos seus ditames, sob pena de ser condenada; a ética é prescritiva e caracterizando-se por ser uma positividade, algo afirmativo, mas não tem a obrigatoriedade coercitiva da lei para seguir seus preceitos, ou seja, a ética é um instrumento da liberdade de escolha. Ela implica em nos preocuparmos com a humanidade e nos leva a redefinir os direitos, e mesmo os direitos humanos, modo de pensar as relações políticas e sociais, o fundamento maior da cidadania contemporânea. Como contraste, o principal objetivo dos moralistas consiste em identificar e denunciar os vários grupos sociais responsáveis pelo que consideram a erosão do tradicional da moralidade social.

Pode a sociedade, o Estado, a família, qualquer um determinar o que é bom para cada um? Como têm ou adquirem eles o aparelho correto para medir o certo, o bom, o justo, o verdadeiro? Como saber se o julgamento e a conseqüente dieta estão corretos? A medida está na pessoa, é suficiente prestar atenção em suas disposições, se elas não frustram as obrigações cotidianas, a justa medida foi encontrada. A investigação do que é próprio da natureza de cada homem e a recomendação de fazer valer tal singularidade, quando da apropriação das regras gerais do cuidado com a vida, sugerem não só a relevância do conhecimento de si, mas também a capacidade e a autonomia para o exercício de uma 'medicina de si'.

E mais ainda, mesmo que por um momento, ou em grau mínimo, deve o cidadão submeter a sua consciência ao legislador? Se a lei é justa, também é em muitos aspectos imperfeita. Existe não para os virtuosos que, por si mesmos, se esforçam em buscar objetivos éticos e estão submetidos voluntariamente às leis, mas para a pessoa comum que cobiça bens e só atua com justiça quando se vê obrigado a fazê-lo por coerção de uma lei. Sua eficácia se deve diretamente ao apego do homem aos bens, e só porque os homens são cobiçosos destes bens a lei tem algum poder sobre eles. Sagazmente aproveita a astúcia do homem para criar e manter uma medida limitada de justiça na sociedade. Mas, a lei, como nos alerta Aristóteles na Ética à Nicômaco, só prescreve atos e não se estende aos motivos ocultos desses atos, e ainda menos a preocupam os atos puramente internos como o desejo 
de assassinato, traição, roubo etc. Por esta razão, não se pode dizer que a lei instale a virtude, pois a virtude autêntica exige que não só se realizem fatos justos, mas também se leve a cabo pelo motivo devido. A simples obediência à lei não é garantia de virtude ética, pois é possível apegar-se à lei e atuar por um motivo puramente egoísta ou utilitário.

Certo é que ao exigir atos justos a todos, a lei predispõe aos homens a adequação à virtude, porém, não pode ir mais além. Portanto, deve ser complementada por uma educação, a saber, a que abarca todos os atos humanos, inclusive os atos internos, e a única que é capaz de produzir a virtude e não só sua aparência. O império das leis é inferior ao império da inteligência viva porque as leis, devido a sua generalidade, não podem determinar sabiamente o que é reto e próprio em todas as circunstâncias, dada a infinidade variada de circunstâncias: só o homem que está no lugar poderá decidir o que é justo e apropriado nas circunstâncias.

Naturalmente que um bom cidadão cumpre as leis, mas não está impedido de discordar e atuar para suas mudanças. Oras, as leis também precisam ser aperfeiçoadas e um cidadão obediente não necessariamente é um bom cidadão, principalmente quando as leis são injustas e tira proveito dela: muitas vezes quem critica a injustiça o faz não porque teme cometer ações injustas, mas porque teme sofrê-las. Do fato das ações estarem de acordo com as leis, não decorre, necessariamente, que sejam praticadas de maneira justa. Também é necessário que o agente se encontre em determinada condição ao pratica-las: em primeiro lugar deve ter conhecimento do que faz; em segundo lugar, deve escolher os atos, e escolhe-los por eles mesmos; e em terceiro lugar, sua ação deve proceder de um caráter firme.

O bom advogado não é aquele que sempre vence as causas para seus clientes, o bom advogado é aquele que promove a justiça. Assim como o bom político não é aquele que sabe comandar homens, que sempre ganha eleições, que tem prestígio e fama: o bom político não é necessariamente um bom condutor de homens em geral, nem precisa se tornar um, mas aquele que demonstra qualidades próprias frente à comunidade e tem por finalidade o bem comum, na verdade, dever de todo cidadão que é político sem saber e ainda desconhecendo seu ofício. O bom político também deve saber de algum modo o que diz respeito à alma humana. Isso se deduz pelo que acontece nos Estados republicanos: os legisladores tornam bons os cidadãos por meio de hábitos que lhes incutem. Esse é o 
propósito de todo político, e quem não logra tal feito falha no desempenho de seu ofício. E isso vale para todos nós e nas questões mais pequeninas!

Enfim, como diziam os antigos, "A errante e inconstante Fortuna não é proibida estar onde quer que queira: no céu ou na terra, ou em qualquer outro ponto do universo". Assim, na medida em que sempre se está sujeito a cruzar seu caminho, o lugar ocupado pelo Homem exige coragem, pois para reinar a verdade, a lei e o julgamento justo não pode faltar a coragem, como refúgio de todas as outras virtudes, como escudo da justiça e como torre da verdade; invulnerável aos vícios, invencível pelos sofrimentos, constante nos perigos, severa contra a cobiça, desdenhadora da riqueza e dominadora da fortuna. Mas de onde vem essa maravilhosa e poderosa virtude da coragem?

Há forte possibilidade que a coragem possa advir através da indignação ética. É a politização do que antes não era politizado: as relações humanas. Ainda que sem uma consciência política, de pouco ou nada valem as boas intenções, deve-se observar que essa revolta, que vem de uma profunda convicção ética, tira a política que está sucumbindo ao tédio da mesmice, à especialização, à abstenção, à indiferença e, alvez, à extinção, e fornece uma nova perspectiva. Também pode vir de sentimentos da injustiça. Mas, é vão esperar que a coragem brote espontaneamente, pois pode ser que a passividade e acomodamento reinem absolutas numa sociedade comercial, onde poucas coisas causam realmente indignação.

Infelizmente, a coragem só pode vir da própria pessoa, de cada um de nós. Crescemos, somos maiores e senhores de nossas escolhas, e cada um tem o direito e o dever de agir no sentido de um mundo mais justo. Não se é habitante desse ou daquele município, estado ou país, mas do mundo. Tanto a cidadania como a política estão mundializadas, e quando falamos o som da nossa voz, se agradável, útil, bom ou honesto, repercute em ondas por toda parte que está interligada na realidade contemporânea, onde qualquer um pode exercer sua cidadania internacional e declarar a sua opinião. Ou seja, podemos ser ouvidos em toda parte; se seremos entendido é um outro problema muito diferente.

Quem quer que ingresse na esfera política deve, em primeiro lugar, estar disposto a arriscar a própria vida; o excessivo amor à vida é um obstáculo à liberdade e sinal inconfundível de servilismo. A coragem tornourse a virtude política por excelência, e só aquele que a possui pode ser admitido numa associação dotada de conteúdo e finalidade 
políticos. A vida "boa" como Aristóteles qualificava a vida do cidadão, é, portanto, não apenas melhor, mas livre de cuidados ou mais nobre que a vida ordinária: é boa exatamente porque, tendo dominado as necessidades do mero viver, tendo se libertado do labor e tendo superado o anseio inato de sobrevivência comum a todas as criaturas vivas, deixa de ser limitada ao processo biológico da vida ou aos infindos temores dos ignorantes.

É fato que todos os homens têm direito pétreo à vida, à liberdade e à busca da felicidade. No cotidiano, esta injunção traduz-se por: se a vida e a liberdade são um problema de todos, e por todos deve ser discutido e resolvido, a busca da felicidade é problema de cada um. Só a cada um compete decidir qual a melhor maneira de ser feliz, desde que não atente contra a vida do outro, fazendo-o sofrer física e moralmente. John Stuart Mill em Sobre a Liberdade faz colocações relevantes para uma reflexão sobre a única justificativa da interferência dos homens, individual e coletivamente, na liberdade de ação de outrem: é a autoproteção! O único propósito com o qual se legitima o exercício do poder sobre algum membro de uma comunidade civilizada contra a sua vontade é impedir dano a outrem.

O próprio bem do indivíduo, seja material seja moral, não constitui justificação suficiente. O indivíduo não pode legitimamente ser compelido a fazer ou deixar de fazer alguma coisa, porque tal seja melhor para ele, porque tal o faça mais feliz, porque na opinião dos outros tal seja sábio ou reto. Essas são boas razões para admoestar, para com ele discutir, para persuadir, para o aconselhar, mas não para coagir, ou para infligir um mal, caso aja de outra forma. A única parte da conduta pelo que alguém deve responder perante a sociedade é a que concerne aos outros. Sobre si mesmo, sobre seu próprio corpo e espírito, o indivíduo é soberano.

O princípio da liberdade aplica-se à humanidade que se tornou capaz de se nutrir da discussão livre e igual, desde o instante em que o homem atinge a capacidade de se orientar para o próprio aperfeiçoamento, pela convicção ou pela persuasão. A coação é inadmissível como método de consecução do próprio bem individual, sendo justificável apenas quando tem em mira a segurança alheia. Cada qual é o guardião conveniente da própria saúde, quer corporal, quer mental e espiritual. E, no entanto, assim como é possível e algumas vezes justificável coagir os homens em nome de algum objetivo (digamos, justiça ou bem estar público) que eles mesmos perseguiriam se fossem esclarecidos, mas não o fazem pelo fato 
de serem cegos, ignorantes ou corruptos, o mesmo se deve fazer com a sociedade ou com a civilização.

E ainda, segundo Mill, os homens ganham mais suportando que os outros vivam como bem lhes parece do que os obrigando a viver como bem parece ao resto: naquilo que não diz respeito aos outros, a individualidade se deve afirmar. As faculdades humanas da percepção, do juízo, do sentimento discriminatório, atividade mental, mesmo preferência moral ou cultural, só se exercitam fazendo uma escolha. Quem faz algo simplesmente porque é o costume, não escolhe. Eis porque são necessárias objeções à interferência governamental quando ela não envolve desrespeito à liberdade. Em primeiro lugar, porque há coisas mais adequadas a serem feitas pelos indivíduos do que pelo governo. Em geral, ninguém está mais em condições de conduzir um negócio, ou de determinar como e por quem deva ser conduzido, do que os pessoalmente interessados nele. Em segundo lugar, é desejável a autonomia e que seja feita por cada um as ações políticas como um meio para a sua educação mental - um modo de robustecer as faculdades ativas, exercitando o discernimento, e proporcionando familiaridade com os assuntos, cujo trato lhes é assim deixado, fazendo parte do treinamento peculiar de um cidadão, a parte prática da educação política de um povo livre, que o tira para fora do círculo estreito do egoísmo pessoal e familiar, e o acostuma à compreensão dos interesses coletivos, à administração dos interesses coletivos - habituando-o a agir por motivos públicos e a guiar a conduta por alvos que unem as pessoas. Em terceiro lugar, porque é necessário limitar a interferência do governo, pois é um grande perigo lhe aumentar desnecessariamente o poder. Toda função que se acrescente às já exercidas pelo governo difunde mais largamente a influência deste sobre as esperanças e os temores, e converte a parte mais ativa e ambiciosa do público em pingentes do governo, ou de algum partido que visa tornar-se governo.

O que antes era um mundo de trevas, torna-se progressivamente algo manipulável pela racionalidade e razoabilidade. A racionalidade cria a disciplina a ser seguida, mas a razoabilidade nos traz a sensibilidade para mudar disciplinas, questioná-las, melho rá-las. E só basta não ter preguiça e ter coragem para exercer seu direito legítimo de dizer que existe, e que não concorda com muitas das coisas que estão estabelecidas à sua revelia; tem esse direito por ter nascido muito depois de ter sido estabelecido boa parte das normas e leis, e tem esse dever se percebe seu equívoco, atuando para o aperfeiçoamento de sua 
convivência. É função de toda ação, enquanto distinta do mero comportamento, interromper o que, de outro modo, teria acontecido automaticamente.

A expansão do exercício consciente da liberdade é o fim prioritário e, simultaneamente, o meio principal do desenvolvimento. $\mathrm{O}$ desenvolvimento consiste na remoção de vários tipos de restrições que deixam às pessoas pouca escolha e pouca oportunidade para exercerem a sua ação racional. O desenvolvimento deve ser encarado como um processo de ampliação das liberdades de que uma pessoa goza. A tônica nas liberdades humanas, ou seja, decorrente de princípios éticos de autonomia e consciência do bem comum, contrasta com perspectivas mais restritas de desenvolvimento, que o identificam com o crescimento do produto nacional bruto, com o aumento das receitas pessoais, com a industrialização, com o progresso tecnológico, ou com a modernização social.

\section{3 - Do Fim ao Começo Sem Fim}

Ao nascer, cada indivíduo pode ser muito diferente, conforme sua constituição natural. Mas é apenas na sociedade que a criança, com suas funções mentais maleáveis e relativamente indiferenciadas, se transforma num ser mais complexo e adquire maturidade. É na relação com os outros seres humanos que a criatura impulsiva e astuta que vem ao mundo, se transforma na pessoa desenvolvida que tem o caráter de um indivíduo, e recebe o nome de ser humano e cidadão. Somente ao crescer num grupo é que o pequeno ser humano aprende a fala articulada. Somente na companhia de outras pessoas mais velhas é que, pouco a pouco, desenvolve um tipo específico de sagacidade e controle dos instintos. E a língua que aprende, o padrão de controle instintivo e a composição adulta que nele se desenvolve, tudo isso depende da estrutura do grupo em que ele cresce e, por fim, de sua posição nesse grupo e do processo formador que ela acarreta. Mesmo dentro de um mesmo grupo, as relações conferidas a duas pessoas e suas histórias individuais nunca são exatamente idênticas. Cada pessoa parte de uma posição única em sua rede de relações e atravessa uma história singular até chegar à morte. O que falta ao homem em termos de predeterminação hereditária, tem que ser substituído por uma determinação social, uma moldagem cultural e, sem dúvida, muita auto-formação. 
A criança, o jovem e o adulto têm que ser educados, reeducados, auto-educados, desde o nascedouro até o momento em que as faculdades físicas e mentais permitirem. Há começo para educação, mas não há fim. Não há dúvidas que quanto mais educado for o indivíduo melhor pessoa e cidadão ele será. Naturalmente, a educação não é garantia de que uma pessoa será um bom cidadão ou uma boa pessoa, mas sem ela terá muito mais dificuldades de se tornar um bom cidadão ou pessoa. Pressuponho, é claro, que todos desejam bons cidadãos, ainda que possa haver muita discordância do que significa "bom cidadão".

Contudo, é possível educar a "natureza humana"? A grande maioria pensa que o conhecimento não é forte, nem capaz de guiar, nem de comandar; sendo de parecer que muitas vezes, embora seja o homem dotado de conhecimento, não é governado por ele, mas por qualquer outra coisa, ora pela cólera, ora pelos prazeres, ora pela dor, algumas vezes pelo amor, e muito freqüentemente pelo medo, e consideram o conhecimento mais ou menos como um escravo que se deixa arrastar por tudo.

Não obstante esta crença de uma natureza passional, o mundo ocidental alimenta também a crença na educabilidade dos homens para o convívio civilizado entre os mesmos. Que fique claro, que falar de educação não é falar propriamente de escola. Ainda que idealizada para educar e muitas possam realizar educação, escolas são até o momento mais instituições de instruções e aprend izagem de códigos numéricos e da língua, com fins a direcionar os alunos para a profissionalização e sua responsabilidade com o trabalho, do que instrumentos de humanização e educação para a cidadania. A educação escolar socializa o indivíduo, mas não politiza o cidadão! Não realiza necessariamente uma educação para cidadania. E a educação precisa estar aninhada na busca de um viver juntos, que esteja para além dos limites da normatização e da legalidade contratual.

Quando se fala em educação para a cidadania não se está pensando em algum tipo de educação moral, mas educação cívica e humanística, que permita a aquisição da tolerância como respeito à alteridade, para a convivência pacífica com posições diferenciadas, assim como com costumes diversos, e ter consciência da co-responsabilidade pelos destinos próprios, da cidade, assim como da humanidade. O que mais se precisa difundir é a percepção, o respeito e a tolerância por traços culturais distintos dos cidadãos e não cidadãos, fazendo com que todos sejam tolerantes com o significar diferenciado das 
pessoas (no sentido de respeito e valorização de manifestações culturais distintas, e não no simples suportar, à distância, as manifestações dos outros em guetos e confrarias).

Falta a percepção e o respeito pelas mais diversas manifestações culturais, assim como perceber a importância e o grande valor da diversidade cultural, como fator ampliador da própria cultura, o que depende de processos educacionais para adquirir maior percepção e, assim, maior produtividade. Ou seja, não deve ser uma educação para um ufanismo nacional, regional ou pessoal, mas uma compreensão do homem como um ser planetário, habitante de uma República entre inúmeras outras, todas elas igualmente com direitos de existir com suas especificidades e diferenças, e dependentes da participação política dos seus cidadãos. Aprender a tratar cada agrupamento humano como uma República autônoma e cada indivíduo como pessoa independente são marcas de um crescimento civilizatório.

O acesso à felicidade p ública requer o cultivo de uma sociabilidade, uma espécie de exercício de humanidade, além da capacidade de se liberar das condições subjetivas privadas, ou seja, das idiossincrasias que naturalmente determinam nosso ponto de vista particular, e que permanecem legítimas, contanto que se mantenham tal qual opinião privada, mas que podem perder a validade no espaço público do debate. A base de toda conduta é que escolho ser eu mesmo e sou livre se assim o quiser. Mas, só pode existir a vontade livre quando as necessidades básicas da vida forem satisfeitas. A livre escolha significa uma opção liberta do desejo de mera sobrevivência. Onde o desejo de sobreviver intervém, a escolha é preconcebida.

Ora, assim como ocorre hoje com as mercadorias que estão sendo produzidas mundialmente, ultrapassando as fronteiras nacionais e territoriais, as pessoas também tendem a ter esse mesmo tipo de circulação, como já ocorre em partes da Europa e tende a ser um fenômeno mundial. Portanto, a pessoa deve estar preparada para viver não apenas no lugar onde nasceu, mas em qualquer parte do mundo, e tentar constituir em conjunto com os demais círculos virtuosos, e sem se contrapor de forma conflituosa, o que gera os círculos viciosos que aumentam os custos sociais e desgastam os esforços individuais. Se os homens não têm prazer na companhia dos outros, quando não existe um poder capaz de aterrorizar a todos, é tarefa pedagógica da sociedade de educar o público e, por esse meio, 
concorrer para o progresso e elevação moral do gênero humano, assim como contribuindo com o bem público.

Se não se quer que os homens se retirem por completo a seus próprios círculos domésticos e dos interesses particulares, se não se quer que se desvaneça por completo o espírito público, haverá que ensinar as homens que por um ilustrado interesse em si mesmo necessitam ajudar-se constantemente uns aos outros e sacrificar uma parte do seu tempo e de sua riqueza ao bem estar da comunidade. O fundamento da ordem pública ou social reside num "egoísmo" ilustrado: cada um aceita a idéia de que ao servir a seus semelhantes se serve a si mesmo e que seu interesse particular deve se articular com o de fazer o bem público.

O fato é que vivemos num mundo civilizado, numa roda mundial onde cada vez mais pessoas se incorporam. Todos precisam ser educados para esse mundo complexo, plural, multifacetado, multidimensional, internacional. Toda criança e jovem precisa estar na escola até os 18 anos, num ensino integral, particularmente os pobres desse mundo. A sociedade, o Estado, a ONU, a humanidade, cada um de nós deve envidar esforços para que toda criança tenha escola com refeições, livros, instrumentos, laboratórios científicos e de artes, computadores, quadras de esporte, teatro, onde se aprende as diversas disciplinas escolares necessárias e imprescindíveis para a vida social, onde aprendam uma segunda língua (fundamental num mundo globalizado), mas também a disciplinar o corpo e a mente, com bons hábitos alimentares e higiênicos, boa saúde e assistência médica e psicológica, etiqueta e bons modos, assim como desenvolver uma cultura humanística e cívica de pertencimento de uma civilização.

Os perigos que ameaçam o homem a partir de fora é de maior intensidade enquanto ainda se encontra na infância ou na primeira juventude; eis porque se deve educar e preparar para vida, pelo menos, até os 18 anos. Tais perigos tornam-se menos prementes tão logo este ser desperta; tão logo ele se desenvolve e atinge sua eficácia graças às forças fundamentais da humanidade livre, graças à energia moral e intelectual. E assim, virtude e estudo acabam por vencer as forças hostis da ignorância. Lembremos que para Maquiavel, a Fortuna domina metade de todas as ações humanas, mas não rende seus favores àquele que meramente assiste, sem nada fazer, e sim ao que age, ao que toma as rédeas nas mãos 
com rapidez e ousadia; a corrente da fortuna não arrasta consigo aquele que, confinado em suas próprias forças, desbrava seu próprio caminho, como um nadador intrépido.

O homem que se quiser tornar cidadão deve ser acostumado à bondade, passando o seu tempo em ocupações dignas e não praticando ações más involuntariamente, como ocorre quando uma criança está solta na rua: não está exercendo a liberdade, está lá porque os adultos se livraram dela ou estão explorando-a. Isso se consegue quando os homens vivem de acordo com uma espécie de reta razão e ordem, contanto que esta tenha força convincente; não a lei que tem poder coercitivo, é preciso regras baseadas numa espécie de sabedoria e razão prática disseminada pelas pessoas, adquirida por um processo educativo, que não só informe, mas que forme.

O que se observa na história é que todos os países que atingiram altos índices de desenvolvimento social e humano traçaram um percurso semelhante. No decorrer de, no mínimo, duas décadas educando com ensino integral seus cidadãos, e com práticas de civismo virtuoso os conselheiros, os políticos e os cidadãos acabam formulando suas análises menos em termos de fins precípuos e mais em termos de meios práticos. Eles passam a se ver menos como mediadores e mais como responsáveis, menos como tribunos eloqüentes das causas populares e mais como defensores competentes do interesse público. As questões práticas de cunho administrativo, legislativo e financeiro adquirem maior relevo. Em duas décadas de experiência cívica há uma mudança radical na atmosfera e na cultura política, passando-se do conflito ideológico à colaboração, do extremismo à moderação, do dogmatismo à tolerância, da doutrina abstrata à gestão prática, da articulação de interesses à agregação de interesses, da reforma social radical ao "bom governo". Uma nova organização social e política pode ensinar a todos as virtudes da paciência, do senso prático e da temperança.

Enfim, mudanças cívicas significativas não decorrem de decretos, mas de vontades instituintes no decorrer de gerações, de aprendizado de valores e novos costumes, de uma educação formal e informal acentuada e dedicada. O paraíso precisa ser construído e não existe sem o esforço individual. Sua construção começa por si mesmo, quando se para de preocupar tanto com as maldades do mundo e percebe e se preocupa com as maldades próprias. Com certeza, boa parte das mazelas do mundo vem de nossas próprias práticas. 
Além disso, será o filho de pais pobre que educará os pais, que apontará alternativas para sua família sair da pobreza, ensinará bons hábitos, higiene, mostrará os direitos que podem recorrer, fornecerá a dimensão do mundo para o restrito mundo particular de ignorâncias restritivas de ações autônomas dos pobres. Naturalmente, para tanto, Estado, sociedade, organismos internacionais precisam se dedicar a construir escolas e melhorar as já existentes, assim como subsidiar as crianças do mundo todo, todas elas sendo sustentadas pelas sociedades. Se isso é viável a curto prazo é difícil avaliar, pois que depende da vontade das pessoas, que podem ser motivadas e desmotivadas por inúmeros fatores, mas a longo prazo não há nada que impeça uma marcha das massas pela educação integral de seus membros, transformando numa vontade política instituinte em todas as partes, principalmente se os países que já possuem tal estrutura educativa contribuírem com africanos e latino-americanos, lugares menos civilizados por excelência, construindo escolas e pagando professores.

Mas, independente da prioridade de educação dos pobres, o ensino em si precisa sofrer profundas transformações, até mesmo o ensino das elites. Ora, o que afasta da verdade não é apenas a ignorância, mas uma aversão a conhecer: a humanidade, a maior parte ambiciosa, não quer saber da verdade que contradiz interesses ou paixões. O inimigo não é apenas a carência de saber, mas uma disposição a ela adversa, que atravessa as várias classes, porém, prepondera entre os ricos e "poderosos" com a ambição de bens e prestígio. Um estudo das ciências humanas e artes humaniza o caráter e o impede de ser cruel. Nada é tão benéfico ao temperamento quanto o estudo das belezas das humanidades, seja a poesia, a literatura, a antropologia, a filosofia, a psicologia, a sociologia, a música ou a pintura. Estas proporcionam uma certa elegância de sentimento e as emoções que excitam são suaves e ternas. Libertam a mente das pressões dos negócios e dos interesses imediatos, e levam aos recônditos da alma humana; estimulam a eflexão, predispõem o espírito à tranqüilidade. E uma delicadeza de gosto é favorável à amizade por não limitar a nossa escolha a menos pessoas, e por nos tornar agradáveis à companhia e à conversação da maior parte dos homens.

Sem dúvida é a ignorância a causa involuntária, sem culpados ou inocentes, da pior das doenças humanas contemporâneas, análoga à loucura: a insensibilidade que gera desproporção e desarmonia social, assim como os regimes políticos corruptos. Enfim, o 
mau funcionamento das instituições civis resvalam numa educação bloqueadora, retardadora ou ineficiente na instauração do equilíbrio social. Este quadro, paulatinamente, geração após geração, ascende num círculo vicioso e perigoso - homens sem uma boa educação na juventude, geram, quando adultos, instituições precárias, beneficiárias apenas das constituições ruins e desestimuladoras das boas, ou seja, engendradoras de mais homens ignorantes e assim sucessivamente. Para quebrar a cadeia, só com o restabelecimento da boa educação, que deve ser vista como uma terapia da alma e da República, e principalmente como um processo consciente de formação humana.

Para tanto, é necessário a ampliação de um espírito humanitário: o último baluarte contra o domínio das trevas, reservado até então às elites, num mundo democratizado deve passar para a responsabilidade do próprio povo. Sem esta passagem, tudo está perdido, pois nem a liberdade nem o desenvolvimento sobreviverão. A idéia de liberdade parte de duas convicções: para se conferir realidade a uma espécie salutar e não corrompida de vida pública, a prioridade está em aprimorar o espírito público e a energia dos cidadãos e não em aperfeiçoar a máquina estatal. A outra convicção é que o valor de um cidadão não se deve medir pela antiguidade de sua linhagem ou pelo volume de suas riquezas, mas, acima de tudo, por sua capacidade de desenvolver os talentos que possui, de atingir um senso adequado do espírito público, e de assim canalizar as energias para o serviço da comunidade, conseqüentemente, da humanidade também, além dos próprios, é claro.

O fato é que é necessária uma educação para a civilização ocidental e que transcenda às especificidades locais. A civilização ocidental não é apenas um estado, mas um processo que deve prosseguir para um tipo mais elevado de sociedade: a idéia de um padrão moral e costumes, tato social, consideração pelo próximo, e numerosos complexos semelhantes, sob um aspecto humanista. O processo de civilização do Estado, a Constituição, a educação e, por conseguinte, o abrandamento de hábitos dos segmentos mais numerosos da população, a eliminação de tudo o que era ainda bárbaro nas condições vigentes, como as penalidades legais, as restrições de classe ou as barreiras que impediam o desenvolvimento do comércio - este processo civilizador, que vem num crescendo desde o renascimento deve seguir-se ao refinamento de maneiras e à pacificação interna dos países e do mundo enquanto um todo. 
A ordem educacional necessária para amenizar as conseqüências da civilização comercial é também uma educação prática, medida pelo caráter que forma, e não tanto pelo conhecimento que acumula. É quase certamente uma educação sem educadores, uma espécie de auto-cultivo, através da participação em forma de acumulação de experiências práticas e teóricas. Fundamentalmente, deve ensinar a aprender! Ora, as ações da vida cotidiana admitem grande variedade e flutuações de opinião. Ao tratar de tais assuntos, e partindo de tais premissas, deve a educação indicar a verdade aproximadamente e em linhas gerais e instrumentalizar as pessoas para que façam seus próprios julgamentos.

Ora, a civilização não é razoável, nem racional, como também não é irracional. É posta em movimento cegamente e mantida em movimento pela dinâmica autônoma de uma rede de relacionamentos, por mudanças específicas na maneira como as pessoas se vêem obrigadas a conviver. Mas não é absolutamente impossível que se possa extrair dela alguma coisa mais razoável, alguma coisa que funcione melhor em termos de necessidades e objetivos. Porque é precisamente em combinação com o processo civilizador que a dinâmica cega dos homens, entremisturando-se em seus atos e objetivos, gradualmente leva a um campo de ação mais vasto para a intervenção planejada nas estruturas social e individual - intervenção esta baseada num conhecimento cada vez maior da dinâmica nãoplanejada dessas estruturas.

Existe uma base de experiência para a crença de que podemos saber o que é justo e bom para o homem na maior parte das vezes, não sempre. Chamo a atenção para as simples experiências relativas ao justo e ao errado que estão na raiz da controvérsia filosófica em torno do direito natural, ou à nossa percepção da injustiça de certas ações, bem como ao fenômeno de admiração da excelência humana (o prazer que se experimenta quando observa-se sinais de virtude ou nobreza humana). Tanto na ciência como na vida diária temos de nos apoiar inevitavelmente no entendimento do mundo baseado no bom senso que fazem distinguíveis as ações nobres e as vis.

Creio que as idéias de justo e de injusto são tão claras, tão universais quanto as de saúde e de doença, de verdade e de falsidade, de conveniência e de inconveniência, o que não quer dizer que sejam as mesmas ou idênticas em todos os lugares e em todas as épocas. Por exemplo, o roubo, o assassinato, o seqüestro, o estupro, a indução ao erro que cause malefícios, a mentira e desonestidade são universalmente condenados ou rejeitados por 
todos os agrupamentos humanos. Os limites do justo e do injusto são muito difíceis de estabelecer na especificidade do dia a dia, assim como é difícil delimitar o estado intermediário entre a saúde e a doença, entre a conveniência e a inconveniência das coisas, entre o falso e o verdadeiro quando se mesclam os matizes e as cores definidas ferem todos os olhares. Mas, é preciso ultrapassar a natureza pessoal para a enunciação de valores de ambição universal, no plano do direito e da justiça, que é o grande salto que define uma sociedade, e talvez qualquer sociedade, que é a passagem das relações de sangue àquelas que são contratadas. Essa mudança permite sair do mesmo e chegar ao outro, ao diferente, ao que no contato ou no contrato com o resto do mundo proporciona a expansão, a novidade.

Nesse sentido, a virtude para que a cidade subsista não deve ser privativo de ninguém, logo se deve envidar esforços para deixar as crianças sociáveis e desviá-las da prática de ações más, para que a pessoa possa se apropriar dos valores éticos, a fim de que fiquem mais brandas e se tornem igualmente aptas tanto para a palavra como para a ação, pois em todo o seu decurso a vida do homem necessita de ações manifestadas ou ativas. A verdade é que numa República todo mundo, pessoas e instituições, é professor de virtude na medida das suas forças, mas disso poucos têm consciência aualmente. Falta às pessoas serem convencidas de suas capacidades - frente ao Estado, a sociedade, a história e a si próprias - e que tenham uma educação política e humanística que sustente um tal convencimento.

É certo que uma dedicação séria às ciências e às artes liberais suaviza e humaniza o caráter, alimentando aquelas emoções mais delicadas em que consistem a honra e a virtude. Raramente acontece de um homem de cultura não ser, ao menos, um homem gentil, sejam quais forem as suas fraquezas. A propensão de seu espírito para os estudos especulativos atenua nele as paixões do interesse e da ambição, e ao mesmo tempo deve dotá-lo de uma sensibilidade maior a todas as exigências e deveres de uma vida decente. Ele sente mais plenamente uma distinção moral entre os temperamentos e costumes.

Eis aqui, portanto, o principal triunfo da arte, da filosofia, das ciências humanas: elas apuram imperceptivelmente o caráter, apontando-nos as tendências que devemos nos esforçar para atingir, por meio de uma constante inflexão do espírito, e do hábito repetido. 
Visa terminar com a alienação do homem, pretende conquistar para ele um conhecimento e, portanto, capacidade de ação - de que está privado devido à educação atual.

Desde a Renascença busca-se um Humanista e os estudos que isso envolveu, abrem amplas perspectivas para as metas que podem ser alcançadas: auto-realização individual, ação em vez de passividade; uma vida em que a razão e a vontade podem ser usadas para melhorar as condições na Terra e para observar as Ições que a natureza e a sociedade reserva aos prudentes e aos atentos.

Os humanistas são leigos cultos ${ }^{91}$, mas não têm o conhecimento para uso numa torre de marfim. É um princípio humanista que se quiser conhecer a verdade, deve-se, à medida que o conhecimento vai ficando mais exato, extenso e especializado, e o fator originalidade decresce assim como a inspiração declina, perceber que a perfeição aumenta, não pelo gênio, que é raro, nem mesmo pelos numerosos talentos de um realizador, mas por uma espécie de trabalho sério de debate de idéias, pois o conhecimento uma obra coletiva. Recorrer à intervenção na esfera pública, promovendo o debate cultural pelos meios de ampla divulgação de opiniões, e assim formulando projetos éticos, jurídicos e políticos de caráter universalista, enraizando valores instituintes de uma ordem jurídica cosmopolita, baseada na racionalidade humana e na esperança legítima de paz perpétua, é a forma de propagar o humanismo.

O humanismo pode ensinar duas coisas: que a obrigação princ ipal de um cidadão é servir a sua comunidade; e que a participação ativa nos assuntos do Estado não deve necessariamente diminuir as capacidades intelectuais ou éticas, na realidade, deve estimulálas. Ele ambiciona levar o estudo para fora das salas escolares, com o fim de eliminar a

\footnotetext{
91. Essa posição de se colocar como um leigo, um leigo culto, diante dos fenômenos culturais é original e bastante filosófica, pois sobre certo sentido, um filósofo, um amigo do saber, não pode deixar de ser um leigo na sua trajetória de busca de sabedoria. Aqui estou me apropriando da idéia do "leigo culto" que conheci através dos textos sobre cultura Para Pensar a Cultura, Dificuldade de um Leigo e Uma Política da Cultura) de Renato Janine Ribeiro, no curso realizado em 2003, A Cultura pela Cultura, e que ficou mais claro através da leitura do seu livro "A Universidade e a Vida Atual: Fellini não via filmes". Compartilho dessas idéias e ideais preconizados pelo autor. Entretanto, tal idéia (não o termo leigo) tem se sedimentando em mim desde a leitura do diálogo de Platão - "Protágoras" - há muitos anos, onde se vê uma defesa brilhante da democracia, quando o autor afirma que os deuses ao distribuírem as qualidades, deram a medicina para uns, a matemática para outros, as artes para outros, mas quando chegaram na política distribuíram igualmente por todos. Hannah Arendt também compartilha dessa posição e em várias passagens de sua obra há referências a necessidade de uma não especialização hermética nessa atividade, sob pena de tirar seu lado ativo e deixa -la como um fenômeno meramente contemplativo e teórico. Bobbio também tem colocações desse teor, colocando-se contrário a uma especialização, ou um mero nominalismo na política sugerindo também a confluência dos saberes para uma abordagem mais abrangente do fenômeno político. É possível traçar uma historicidade dessa idéia, mas me parece mais importante adotá-la e colocá-la em prática.
} 
separação e o dissídio entre o erudito e o popular e, com o tempo, criar um projeto que leve a cultura intelectual mais perto de satisfazer as necessidades dos cidadãos. Os humanistas intentam fazer algo como uma educação para o cidadão ao mesmo tempo em que despertam uma disciplina e um método para surgir o estudioso.

Para o humanismo não se pode deixar os homens soltos, como animais sagrados, para pastarem livremente e ver se, por acaso e impulso próprio, venham a deparar coma virtude. Começando de pouquinho desde pequena, enquanto vive, deve a criança ser instruída e educada; desde que ela compreenda o que lhe diz, deve-se conjugar esforços para que se desenvolva da melhor maneira possível; toda palavra e todo ato enseja oportunidade para ensinar- lhe o que é justo ou o que é injusto, o que é honesto e o que é vergonhoso. Depois, deve-se enviar à escola e aos professores para que cuidem com mais rigor dos costumes da criança, assim como apresentem a vida para que apreenda o mundo sem uma visão puramente doméstica e particular: é quando começa a ação pública e se apresenta à sociedade.

História, bons autores clássicos, as grandes obras do pensamento não ensinam propriamente virtude, antes exercitam o pensamento e ampliam a sensibilidade tão somente. O objetivo maior desse gênero educativo e literário é apontar para as interpretações do passado que serviram de guia ético para o comportamento, e de forma pedagógica e também pragmática, dado seu conteúdo predominantemente político e sua apropriação imediatamente voltada para a ação individual, desenvolver hábitos mentais para pensar o conflito de interesses dos homens. A educação humanista tem como objetivo não só formar homens educados, mas também bons cidadãos, uma educação que infunde aos homens o desejo de participar na vida diária e nos assuntos públicos da comunidade.

Além disso, o humanismo ancora a aliança entre retórica e filosofia, numa concepção do papel da educação na vida da cidade e na formação do homem. Ora, o elogio da eloqüência implica a descoberta do espaço cívico e de sua importância para a vida dos homens, cuja ferramenta útil contida na contraposição entre interesses privado, estatal e público, é a possibilidade de fala e ação política na esfera pública, que pressupõe entender e se fazer entender. Esse uso retórico tem um óbvio significado prático, especialmente numa sociedade que lida com todos os seus negócios legais, políticos e diplomáticos, por meio de discursos e debates formalizados. 
Para o humanista não resta dúvida de que não existe transmissão da virtude e de que é preciso adquirí la ao longo da vida e manifestá-la através de atos por todos reconhecidos e que sirvam à cidade e não apenas aos próprios interesses. O caminho para atingir esse patamar de existência é se dedicar com afinco ao estudo, inclusive, para um autoaperfeiçoamento. Os estudos são ocasiões de prática da virtude cívica e não dependem em absoluto de qualidades herdadas, mas da disponibilidade e da oportunidade de se aprender. O humanismo propugna uma virtude adquirida por mérito e acessível a todos que forem capazes de se interessar pelos studia humanitatis - o conjunto de conhecimentos humanos.

Sócrates, o grande mentor do humanismo de todas as épocas, depurava as pessoas de suas opiniões, isto é, daqueles pré-julgamentos não examinados que impedem o pensar, ao sugerir que sabem o que não tanto não sabem como não podem saber, ajudando-os a se livrar das opiniões preconceituosas, sem, entretanto, torná-los necessariamente bons, mas dando-lhes a verdade. Como fazia isso? Interrogando seu interlocutores: as verdadeiras perguntas dizem respeito ao sentido da vida e elas nos despojam de nossas frágeis certezas, de nossas mesquinhas convicções, e nos põem em confronto com a vertigem de nossa insondável ignorância. A educação socrática é uma educação para a virtude, para a virtude do cidadão ou para a virtude do homem. As virtudes são similares à arte no modo que se adquirem: os homens aprendem a ser bons realizando ações boas. As virtudes morais surgem nos homens não por natureza nem são contrárias à mesma: os homens têm potencial natural para desenvolvê-las, porém, para fazê-lo precisa acostumar-se e esforçar-se.

O pensamento socrático é paradigma do humanismo que provoca a perplexidade, desaloja padrões estabelecidos, como se um dos resultados imediatos fosse interromper nossos julgamentos e ações cotidianas, baseadas em valores e princípios em geral não submetidos a exame. O conhecimento liberta não apenas por oferecer possibilidades mais amplas, entre as quais se pode realizar as escolhas, mas, por nos preservar da frustração de tentar o impossível. Contrapõe-se a dogmas cristalizados, regras de comportamento baseadas em hábitos silenciosamente incorporados e, na sua maioria, de antemão tomados como certos. O pensamento tem o poder de provocar espanto e perplexidade, assim como a consciência de si. A característica primária dessa consciência é evocar a pluralidade dentro de nós mesmos, a capacidade de criar um outro para si mesmo, de imaginar pontos de vistas alheios. Faz com que possamos aparecer para nós mesmos, trazer alteridade à reflexão. A 
atividade de pensar reforça a primazia da comunicabilidade, pluralidade e diversidade de pontos de vista, na formação de nossas opiniões, na forma como constituímos nossa visão particular e única do mundo.

Todavia, sempre que se fala em processo educativo logo se pensa no Estado ou no governo como executor das tarefas, omitindo o dever de cada um nessa função. Nem Estado nem governo podem obrigar os cidadãos a atuar moralmente, pois ainda que as ações possam ser reguladas, as intenções indispensáveis para a moral dessas ações não podem ser induzidas de fora. A lei não tem força com relação à obediência sem a força do hábito, e este só é criado sobre um largo período. O que significa que a consideração crítica não deve focar tanto as leis, mas antes a cultura duradoura ou o caráter político e civilizatório que subjaz na sociedade. Cumpre ao legislador inspirar aos cidadãos os sentimentos que convêm para estabelecer uma ordem, mas a lei só tem força para se fazer obedecer no hábito, e o hábito só se forma com o tempo, com os anos. O âmbito da sociedade civil está limitado até o momento de forma drástica pelo sentimento disseminado que por si mesma uma pessoa é incapaz de se conduzir à virtude, e que só a força da lei pode dirigir os homens.

Ora, um ensino público só é dever do Estado quando a sociedade civil assim impõe. É público não por ser estatal, mas por estar baseado em valores republicanos da sociedade, que necessariamente englobam a laicidade (incluindo a diferença de opiniões e o exercício do raciocínio crítico), a igualdade de todos, a liberdade de oportunidades e a fraternidade humanitária. O ensino é público, sobretudo, porque seus resultados devem difundir-se por toda a sociedade, pertencendo à esfera do direito, que é potencialmente universal, e não ao âmbito do privilégio, que é limitado. Um ensino público ministra também uma formação ética que consiste, antes de tudo, na responsabilidade ante a sociedade e na preocupação com a apropriação social dos resultados.

A idéia de que o Estado deve administrar escolas, gerir a educação, gerenciar o ensino é uma distorção da idéia de que o Estado deve garantir a educação de todos, uma idéia republicana por excelência. $\mathrm{O}$ que o Estado deve fazer não é necessariamente manter uma rede escolar ou uma suposta gratuidade ${ }^{92}$ no ensino, mas, garantir ensino para todos -

\footnotetext{
92. Aliás, nada mais falso do que isso, já que o Estado paga caríssimo por suas escolas.
} 
seja pagando escolas para alunos carentes, seja construindo escolas - àqueles que não tem possibilidade de pagar, garantindo que ricos e pobres possam desfrutar do mesmo nível de ensino, mas o que só é possível quando isso é produto da vontade da sociedade não apenas dos governantes.

O problema tem sido sempre tentar mudar da água para o vinho o comportamento humano e social, pressupondo que dele possa redundar num bom comportamento de todos. O regime que se deve buscar não pode pressupor a virtude da índole que está além das pessoas privadas ou que a educação colocou: um tipo intermediário que não se caracteriza tanto pela possessão de virtudes quanto pela ausência de vícios, e por circunstâncias externas, favoráveis à aquisição de virtude. Uma grande parte do pensamento político desde Maquiavel, mas, principalmente, depois dos Iluministas, tem um caráter doutrinário e revolucionário que gera uma expectativa de que o melhor regime ou o melhor governo pode ser realizado em qualquer parte e a qualquer hora: esperam assegurar a viabilidade da boa ordem social através do rebaixamento das normas da ação política e ética, isto é, definindo o melhor regime por referência à maneira como os homens vivem "realmente", e aos objetivos que todas as sociedades têm, de fato, em vista, mais preocupados em realizar os desejos que o bem estar social.

A República e a idéia de dever que nela está saliente, só pode ser construída por intensa educação, que permita ao cidadão conhecer os códigos sociais e sua legitimidade. Essa educação deve gerar a autonomia política e econômica do cidadão. A educação ensina que para haver acesso de todos aos bens e à justiça, para se satisfazer o desejo de ter, é preciso refrear o desejo de mandar, e compreender que quando todos mandam, todos igualmente obedecem e, por conseguinte, devem saber cumprir a lei que emana de sua própria vontade. Infelizmente, o clamor popular deseja da República a distribuição dos bens, quando ela existe para a gestão do poder dos cidadãos. É a participação política que empodera o cidadão, que traz conhecimento e, conseqüentemente, autonomia; não as garantias do Estado ou do governante.

Uma boa educação é tudo que uma pessoa precisa para sobreviver no mundo contemporâneo com dignidade: quem tem conhecimento tem poder, tem possibilidades, tem estendido seu mundo de oportunidades. Uma educação que disciplina a mente e promove a prudência põe em condições de administrar do melhor modo sua própria casa, e, 
nos negócios públicos deixará qualquer um apto para dirigi-los e para discorrer sobre eles. Mas, mesmo para perceber esse processo educativo, deve ocorrer um processo educacional que direcione o olhar e a sensibilidade para a coisa pública. Nesse sentido, a educação precisa fornecer ao povo, qualquer povo, instrumental retórico, emocional, maturidade política para os cidadãos expressarem os conflitos contemporâneos, que transitam em torno dos direitos humanos como processo civilizatório, nomeadamente, a igualdade jurídica entre os sexos e o respeito mútuo pela diversidade.

O fato é que o homem pode modificar-se para pior, ou por efeito do tempo, ou do cansaço, ou da doença, preguiça ou por qualquer outro motivo, pois o verdadeiro mal é verse alguém privado de conhecimento. E nenhum homem erra ou pratica deliberadamente qualquer mau ou coisa cruel, já que as pessoas cometem inúmeras ações involuntariamente: não se pode fazer censura, uma vez que a geração dos tolos é infinita (da qual não me excluo). Não se deve procurar a perfeição entre aqueles que nos relacionamos nessa extensa Terra; também não se deve louvar ninguém; satisfaçamo-nos com quem se mantém num meio-termo e não faz mal algum. É importante saber reconhecer voluntariamente quem quer que não pratique ato vil, mesmo que esteja incapacitado de praticar o bem.

A superação do individualismo egoísta, que beira ao mesquinho, é central ao desenvolvimento civilizatório. E mais um paradoxo: a ação individual é essencial nesse sentido, mesmo que a liberdade de ação esteja grandemente condicionada pelas oportunidades sociais, políticas e econômicas. Mas, há algo que se pode buscar ainda que todos os canais para a ação política aparentam estar fechados, refiro-me à auto-educação, missão de todo republicano, a busca sincera de seu aperfeiçoamento particular como forma de contribuir para o aprimoramento público. Fundamentalmente, melhora-se o mundo, a República, a sociedade, melhorando-se a si mesmo; se puder contribuir com o aperfeiçoamento ético e político dos demais, está sendo um cidadão dedicado também. 


\section{Referências:}

abBagnano, N.; VISAlBerghi, A.; História de la Pedagogia, traduzido por Jorge Hernandez Campos, Mexico: Fondo de Cultura Econômica, 1995.

AGAMBEN, G.; Homo Sacer: o poder soberano e a vida nua I, traduzido por Henrique Burigo, Belo Horizonte: Editora UFMG, 2002.

AGUIAR, Odílio A.; Filosofia e Política no pensamento de Hannah Arendt - tese de Doutorado em Filosofia, São Paulo: USP/FFLCH, 1998.

AL-JABRI, M. A.; Introdução à Crítica da Razão Árabe, traduzido por Roberto Leal Ferreira, São Paulo: UNESP, 1999.

ARANTES, A. A.; O Que é Cultura Popular, Coleção Primeiros Passos. São Paulo: Brasiliense, 1981.

ARENDT, H.; A Condição Humana, traduzido por Roberto Raposo, Rio de Janeiro: Forense-Universitária; Rio de Janeiro: Salamandra; São Paulo: EDUSP, 1981.

ARENDT, H.; Responsabilidade e Julgamento, traduzido por Rosaura Eichenberg, São Paulo: Companhia das Letras, 2004.

ARENDT, H.; Sobre a Violência, traduzido por André Duarte, Rio de Janeiro: Relume Dumará, 1994.

ARENDT, H.; A Dignidade da Política: Ensaios e Conferências, traduzido por Helena Martins e outros, Rio de Janeiro: Relume-Dumará, 1993.

ARENDT, H.; Entre o Passado e o Futuro, traduzido por Mauro W. Barbosa. São Paulo: Perspectiva, 1972.

ARENDT, H.; Origens do Totalitarismo, traduzido por Roberto Raposo, São Paulo: Companhias das Letras, 1989.

ARENDT, H.; A Vida do Espírito: o pensar, o querer, o julgar, traduzido por Antônio Abranches et alli, Rio de Janeiro: Relume-Dumará, 1992.

ARENDT, H.; O que é política?, organizado por Ursula Ludz, traduzido por Reinaldo Guarany, Rio de Janeiro, Bertrand Brasil, 1998.

ARENDT, H.; Eichmann em Jerusalém: um relato sobre a banalidade do mal, traduzido por José Rubens Siqueira, São Paulo: Companhias das Letras, 1999. 
ARENDT, H.; Homens em tempos sombrios, traduzido por Denise Bottmann, São Paulo: Companhias das Letras, 1987.

ARIÈS, P.; DUBY, G.; História da Vida Privada, v. 1, traduzido por Hildegar Feist, 11. Impressão, São Paulo: Companhias das Artes, 1989.

ARISTÓFANES; As Nuvens, V. Sócrates, traduzido por Jaime Bruna et alli. Coleção Os Pensadores. São Paulo: Abril Cultural, 1980.

ARISTÓTELES; A Política, traduzido por Nestor Silveira Chaves, São Paulo: Edipro, 1995.

ARISTÓTELES; Ética a Nicômaco, traduzido por Vincenzo Cocco et al., Coleção Os Pensadores, São Paulo: Abril Cultural, 1979.

ARON, R.; Estudos Políticos, traduzido por Sérgio Bath, 2. ed., Brasília: Editora Univer sidade de Brasília, 1985.

AVRITZER, L.; A moralidade da democracia: ensaios em teoria habermasiana e teoria democrática, São Paulo: Perspectiva; Belo Horizonte: UFMG, 1996.

BARON, Hans; Em Busca Del Humanismo Cícivo Florentino: ensayos sobre el cambio del pensamiento Medieval Moderno, Mexico: Fundo de Cultura Económica, 1992.

BARZUN, Jacques; Da Alvorada à Decadência : a história da cultura ocidental de 1500 aos nossos dias, traduzido por Álvaro Cabral, Rio de Janeiro: Campus, 2002.

BAUMAN, Z.; Ética Pós-moderna, traduzido por João Rezende Costa, São Paulo: Paulus, 1997.

BERLIN, Isaiah; Estudos sobre a humanidade: uma antologia de ensaios, traduzido por Rosaura Eichenberg, São Paulo: Companhia das Letras, 2002.

BICUDO, H.; Violência: o Brasil Cruel e sem Maquiagem, São Paulo: Moderna, 1994.

BIGNOTTO, Newton; Origens do Republicanismo Moderno, Belo Horizonte: Ed. UFMG, 2001.

BIGNOTTO, Newton (Org.); Pensar a República, Belo Horizonte: Ed. UFMG, 2000.

BOBBIO, N.; Estado, Governo, Sociedade : para uma teoria geral da política, traduzido por Marco Aurélio Nogueira, 6. ed., São Paulo: Paz e Terra, 1997.

BOBBIO, N.; Sociedade e Estado na filosofia política moderna, traduzido por Carlos Nelson Coutinho, São Paulo: Brasiliense, 1986. 
BObbiO, N.; MATTeucci, N.; PASQuinO, G.; Dicionário de Política, v. 1 e 2, 11. ed., traduzido por Carmen C. Varriale, Gaetano Lo Mônaco, João Ferreira, Luis Guerreiro Pinto Caçais e Renzo Dini, Brasília: Editora Universidade Brasília, 1998.

CANTO-SPERBER, M. (Org.); Dicionário de Ética e Filosofia Moral, traduzido por Ana Maria Ribeiro-Althoff e outros, v.1 e 2, São Leopoldo: Editora Unisinos, 2003.

CARDOSO Jr., N. N.; O Declínio da Esfera Pública no Pensamento de Hannah Arendt, Dissertação de Mestrado, Brasília: Universidade de Brasília, 2003.

CARDOSO, S. (org.); Retorno ao Republicanismo, Belo Horizonte: Editora UFMG, 2004.

CARValho, J. M.; Pontos e Bordados: escritos de história política, Belo Horizonte: UFMG, 1999.

CASSIRER, E.; Ensaio sobre o homem: introdução a uma filosofia da cultura humana, traduzido por Tomás Rosa Bueno, São Paulo: Martins Fontes, 2001.

CASSIRER, E.; Kant, Vida Y Doctrina, traduzido por Wenceslao Roces, 5. ed., Mexico: Fondo de Cultura Econômica, 1993.

CASSIRER, E.; Indivíduo e Cosmo na Filosofia do Renascimento, traduzido por João Azenha Jr., São Paulo: Martins Fontes, 2001.

CHÂTEleT, F.; DUHAMEL, O.; PISIER-KOUCHNER, É.; História das Idéias Políticas, traduzido por Carlos Nelson Coutinho, Rio de Janeiro: Zahar, 1994.

CONSTANT, B.; "Da Liberdade dos Antigos Comparada à dos Modernos”. In: Filosofia Política, Porto Alegre: L\&PM, 1985, n. 2.

COURTINE-DERNAMY, S.; O cuidado com o mundo: diálogo entre Hannah Arendt e alguns de seus contemporâneos, traduzido por Maria Juliana Gambogi Teixeira, Belo Horizonte: UFMG, 2004.

CRespigny, A. de \& Minogue, K. R.; Filosofia Política Contemporânea, traduzido por Yvonne Jean, Brasília: Editora Universidade de Brasília, 1982.

DADOUN, R.; A Violência: Ensaio acerca do "homo violens", traduzido por Pilar Ferreira de Carvalho e Carmem de Carvalho Ferreira, Rio de Janeiro: Difel, 1998.

DALlARI, D. de Abreu; O Que é Participação Política, São Paulo: Brasiliense, 1984.

DAHL, R.; Sobre a Democracia, traduzido por Beatris Sidou, Brasília: UNB, 2001. 
DARNTON, R.; Boemia Literária e Revolução: o submundo das letras no Antigo Regime, traduzido por Luis Carlos Borges, São Paulo: Companhia das Letras, 1987.

DE BONI, L. A.; De Abelardo a Lutero: estudos sobre filosofia prática na Idade Média, Porto Alegre: Edipucrs, 2003.

DE MASI, D.; A sociedade Pós-Industrial, traduzido por Anna Maria Capovilla e outros, São Paulo: Editora Senac, 2000.

Dicionário Houaiss da Língua Portuguesa, $1^{\text {a }}$. Edição, Rio de Janeiro: Objetiva, 2001.

ELIAS, N.; O Processo Civilizador: formação do Estado e Civilização, v. 2, traduzido por Ruy Jungmann, Rio de Janeiro: Zahar, 1993.

ELIAS, N.; O Processo Civilizador: Uma História dos Costumes, v. 1, traduzido por Ruy Jungmann, Rio de Janeiro: Zahar, 1994.

ELIAS, N.; Os Estabelecidos e os outsiders, traduzido por Vera Ribeiro, Rio de Janeiro: Zahar, 2000.

ELIAS, N.; A sociedade dos indivíduos. Schröter, M. (Org.); traduzido por Vera Ribeiro. Rio de Janeiro: Zahar, 1994.

ESTEVES, Paulo L. M. L.; “Cordialidade e familismo amoral: os dilemas da modernização". In Revista Brasileira de Ciências Sociais, v.13, n.36, São Paulo: Anpocs, fev. 1998.

DELEUZE, G.; GUATTARI, F.; O Anti-édipo: capitalismo e Esquizofrenia, traduzido por George Lamazière, Rio de Janeiro: Imago, 1976.

DUSO, Giuseppe (Org.); O Poder: história da Filosofia Política Moderna, traduzido por Andréa Ciacchi, Líssia da Cruz e Silva e Giuseppe Tosi, Petrópolis, RJ: Vozes, 2005.

FEIJÓ, M. C.; O Que é Política Cultural, Coleção Primeiros Passos, São Paulo: Brasiliense, 1992.

FINLEY, M. I.; Democracia antiga e moderna, traduzido por Waldéa Barceloos at ali, Rio de Janeiro: Graal, 1988.

FOUCAUlT, M.; Microfísica do Poder, traduzido por Roberto Machado, Rio de Janeiro: Edições Graal, 1979.

FOUCAUlT, M.; Vigiar e Punir história da violência nas prisões, traduzido por Ligia M. Ponde Vassallo, 7. ed., Petrópolis, RJ: Vozes, 1989. 
GARCIA CANCLINI, N.; Culturas Híbridas: estratégias para entrar e sair da modernidade, traduzido por Heloíza Pezza Cintrão, Ana Regina Lessa, 2. ed., São Paulo: EDUSP, 1998.

GinZBurg, E.; CAStelnuOvo, E.; PONI, C.; A Micro-História e outros ensaios; traduzido por António Narino Lisboa, Rio de Janeiro: Bertrand Brasil: Difel, 1991.

GLOTZ, Gustave; A Cidade Grega, traduzido por Henrique de Araújo Mesquita e Roberto Cortes de Lacerda, Rio de Janeiro: Difel, 1980.

GOULEMOT, J.; Esses Livros que se lêem com uma só mão, traduzido por Maria Aparecida Correa, São Paulo: Discurso Editorial, 2000.

HALL, S.; Identidades Culturais na Pós-modernidade, traduzido por Tomaz Tadeu da Silva e Guacira Lopes Louro, Rio de Janeiro: DP\&A, 1997.

HARDT, M. e NEGRI, A.; O Império, traduzido por Berilo Vargas, 3. ed. - Rio de Janeiro: Record, 2001.

HEIDEGGER, Martin - Sobre o Humanismo, traduzido por Emmanuel Carneiro Leão,

Rio de Janeiro: Tempo Brasileiro, 1967.

HOBBES, Thomas; Leviatã, traduzido por João Paulo Monteiro e Maria Beatriz Nizza da Silva, São Paulo: Nova Cultural, 2000.

HOBSBAWM, E.; Era dos extremos: o breve século XX - 1914-1991, traduzido por Marcos Santarrita, São Paulo: Companhia das Letras, 1995.

HUME, D.; Ensaios Morais, Políticos e Literários, traduzido por Luciano Trigo, Rio de Janeiro: Topbooks Editora, 2004.

JAEGER, W.; Paidéia: a formação do homem grego, traduzido por Artur M. Parreira, São Paulo: Martins Fontes, 1986.

JASMIN, M. G.; Racionalidade e História na Teoria Política, Belo Horizonte: Ed. UFMG, 1998.

JOHNSON, R. et alli; O Que é, afinal, Estudos Culturais?, organizado e traduzido por Tomaz Tadeu da Silva, Belo Horizonte: Autêntica, 1999.

KANT, I.; À Paz Perpétua, traduzido por Marco A. Zigano, São Paulo/Porto Alegre: L\&PM, 1989.

KANT, I.; Critica de la Razon Practica, traduzido por J. Rovira Armengol, Buenos Aires: Losada, 1961. 
KANT, I.; Crítica da Razão Pura, traduzido por Valério Rohden e Udo Baldur Moosburger, Coleção Os Pensadores, São Paulo: Abril Cultural, 1980.

KANT, I.; Doutrina do Direito, traduzido por Edson Bini, 3. ed., São Paulo: Ícone, 1993.

KANT, I.; Fundamentação da Metafísica dos Costumes, traduzido por Tânia Maria Bernkopf, Paulo Quintela e Rubens Rodrigues Filho, Coleção Os Pensadores, São Paulo: Abril Cultural, 1980.

KANT, I.; Idéia de uma História Universal de um Ponto de Vista Cosmopolita, traduzido por Rodrigo Naves e Ricardo Terra, Coleção Elogio da Filosofia, São Paulo: Brasiliense, 1986.

KANT, I.; Prolegômenos, traduzido por Tânia Maria Bernkopf, Paulo Quintela, Rubens Rodrigues Filho, Coleção Os Pensadores, São Paulo: Abril Cultural, 1980.

KANT, I.; Resposta à Pergunta: Que é Esclarecimento?, traduzido por Raimundo Vier, Coleção Textos Seletos, Petrópolis, RJ: Vozes, 1974.

KRAUSE, S.; SCHMITT, R.; Partidos e Coligações Eleitorais no Brasil, Rio de Janeiro: Fundação Adenauer; São Paulo: Editora da UNESP, 2005.

LA BOÉTIE, E.; Discurso da servidão voluntária, 4. ed., traduzido por Laymert Garcia dos Santos, São Paulo: Brasiliense, 1987.

LAFER, Celso; A Reconstrução dos Direitos Humanos: um diálogo com o pensamento de Hannah Arendt, São Paulo: Companhia das Letras, 1988.

LAFER, Celso; Ensaios sobre a Liberdade, São Paulo: Perspectiva, 1980.

LEBRUN, G.; O Que é Poder, traduzido por Renato Janine Ribeiro e Silvia Lara Ribeiro, São Paulo: Brasiliense, 1981.

LÉVI-STRAUSS, C.; A noção de Estrutura em Etnologia, Raça e História, traduzido por Eduardo P. Graeff e outros, Coleção Os Pensadores, São Paulo: Abril Cultural, 1980.

LOCKE, J.; Segundo Tratado sobre o Governo, traduzido por Anoar Aiex, Coleção Os Pensadores, $1^{\text {a }}$. Edição, São Paulo: Abril Cultural, 1973.

LULLIEN, F.; Fundar a Moral: diálogo de Mêncio com um filósofo das Luzes, traduzido por Maria das Graças de Souza, São Paulo: Discurso Editorial, 2001.

MACFARlane, A.; A Cultura do Capitalismo, traduzido por Ivo Korytowski, Rio de Janeiro, Zahar, 1989. 
MAfFettone, S.; VECA, S.(Orgs.); A Idéia de Justiça de Platão a Rawls, traduzido por Karina Jannini, São Paulo: Martins Fontes, 2005.

MANDEVILLE, Bernard; La Fabula de las Abejas o los vicios privados hacen la prosperidad publica. Comentário crítico, histórico e explicativo de F. B. Kaye, traduzido por José Ferrater Mora. Mexico: Fondo de Cultura Económica, 2001.

MAQUIAVEL, N.; O Príncipe, traduzido por Sérgio Bath, Brasília: Editora Universidade de Brasília, 1987.

MARQUES DE SADE; A Filosofia na Alcova, traduzido por Martha A. Haecker, Rio de Janeiro: JCM Editores, 1968.

MENDOZA, P. A.; MONTANER, C. A.; LlOSA, A. V.; Manual do Perfeito Idiota Latino -americano, traduzido por Rosemary Moraes e Reinaldo Guarany, 2. ed., Rio de Janeiro: Bertrand Brasil: Instituto Liberal, 1998.

“Mesa Redonda: Por que rir da Filosofia Política?”. In Revista Brasileira de Ciências Sociais, v. 13, n. 36, São Paulo: Anpocs, fev. 1998.

MILL, J. S.; Sobre a Liberdade, traduzido por Alberto da Rocha Barros, Petrópolis, RJ: Vozes, 1991.

MONTAIGNE, Michel de; Ensaios, traduzido por Sergio Millet, Coleção Os Pensadores, $1^{\text {a }}$. Edição, São Paulo: Abril Cultural, 1972.

MONTESQUIEU; Do Espírito das Leis, traduzido por Fernando Henrique Cardoso e Leôncio Martins Rodrigues, 2a . ed., São Paulo: Abril Cultural, 1979.

NASCIMENTO, Maria das G. de S.; Voltaire: a razão militante, 4. ed., Coleção Logos, São Paulo: Moderna, s/data.

NEGT, O.; KLUGE, A.; O que há de Político na política?, traduzido por João Azenha Jr., São Paulo: UNESP, 1999.

NIETZSCHE, F.; Humano, Demasiado Humano: um livro para espíritos livres, $6^{\text {a }}$. reimpressão, tradução, notas e posfácio de Paulo César de Souza, São Paulo: Companhia das Letras, 2000.

NIETZSCHE, F.; Obras Incompletas, 2. ed., tradução e notas de Rubens Rodrigues Filho, Coleção Os Pensadores, São Paulo: Abril Cultural, 1978. 
NOVAES, R.; VANNUCHI, P. (Org.); Juventude e Sociedade: Trabalho. Educação, cultura e Participação, São Paulo: Editora Fundação Perseu Abramo; São Paulo: Instituto Cidadania, 2004.

ORTEGA Y GASSET, José; A Rebelião das massas, traduzido por Herrera Filho, Rio de Janeiro: Ibero-americano, 1971.

PERELMAN, C.; Ética e Direito, traduzido por Maria Ermantina Galvão G. Pereira, São Paulo: Martins Fontes, 1996.

PLATÃO; Defesa de Sócrates, traduzido por Jaime Bruna. Coleção Os Pensadores. São Paulo: Abril Cultural, 1980.

PLATÃO; Górgias, traduzido por Carlos Alberto Nunes, 2. ed. revisada, Belém: EDUFPA, 2002.

PLATÃO; Protágoras, traduzido por Carlos Alberto Nunes, 2. ed. revisada, Belém: EDUFPA, 2002.

PLATÃO; República, traduzido por Maria Helena da Rocha Pereira, 3. ed., Lisboa: Fundação Calouste Gulbenkian, 1980.

POCOCK, J. G. A.; Linguagens do Ideário Político, traduzido por Fábio Fernandez, São Paulo: EDUSP, 2003.

POPPER, K.; A miséria do historicismo, traduzido por Octanny S. da Mota e Leônidas Hegenberg, São Paulo: Cultrix/EDUSP, 1980.

POPPER, K.; "Previsão e profecia nas ciências sociais", In. GARDINER, Patrick, Teorias da História, traduzido por Vitor Matos Sá, 3. ed., Lisboa: Fundação Calouste Gulbenkian, 1984.

PRACONTAL, M.; A impostura científica em dez lições, traduzido por Álvaro Lorencini, São Paulo: Ed Unesp, 2004.

PUENTE, F. R. (Org.); Os Filósofos e a Mentira, Belo Horizonte: Editora da UFMG, 2002.

PUTNAM, R. D.; Comunidade e Democracia : a experiência da Itália moderna, traduzido por Luiz Alberto Monjardim, Rio de Janeiro: Ed. FGV, 2000.

RAWLS, J.; O Liberalismo Político, traduzido por Dinah de Abreu Azevedo, São Paulo: Ática, 2000. 
RIBAS, C. M.; Justiça em Tempos Sombrios : a justiça no pensamento de Hannah Arendt, Ponta Grossa: Ed. UEPG, 2005.

RIBEIRO, R. J.; A Democracia, São Paulo: Publifolha, 2001.

RIBEIRO, R. J.; “A Filosofia Política na História”. In: Filosofia Política, Porto Alegre: L\&PM, 1985, n. 2.

RIBEIRO, R. J.; A República, São Paulo: Publifolha, 2001.

RIBEIRO, R. J.; A Sociedade contra o social: o alto custo da vida pública no Brasil, São Paulo: Companhia das Letras, 2000.

RIBEIRO, R. J.; A Última Razão dos Reis : ensaios sobre filosofia e política, São Paulo: Companhia das Letras, 1993.

RIBEIRO, R. J.; A Universidade e a Vida Atual: Fellini não via filmes, Rio de Janeiro: Campus, 2003.

RIBEIRO, R. J., Ao Leitor sem medo: Hobbes escrevendo contra o seu tempo, São Paulo: Brasiliense, 1984.

RIBEIRO, R. J.; O Afeto Autoritário: televisão, ética e democracia, São Paulo: Ateliê Editorial, 2004.

RIBEIRO, R. J.; Por uma Nova Política: uma campanha na SBPC, São Paulo: Ateliê Editorial, 2003.

ROSENFIELD, D. L.; Lições de Filosofia Política: O Estatal, o Público e o Privado, Porto Alegre: L\&PM, 1996.

ROUSSEAU, J.J.; Os Devaneios do Caminhante Solitário, traduzido por Fúlvia Maria Luiza Moretto, Brasília: Ed. da Universidade de Brasília, 1986.

ROUSSEAU, J.J.; O Contrato Social, traduzido por Rolando Roque da Silva, São Paulo Cultrix, 1975.

SANTO AGOSTINHO; O Livre-Arbítrio, traduzido por Nair de Assis Oliveira, São Paulo: Paulus, 1995.

SANTO TOMÁS DE AQUINO; Escritos Políticos de Santo Tomás de Aquino, traduzido por Francisco Benjamin de Souza Neto, Petrópolis, RJ: Vozes, 1995.

SANTOS, J. L.; O que é cultura, Coleção Primeiros Passos, 5. ed., São Paulo: Brasiliense, 1986. 
SCHOPEnhauer, A.; Da Morte, Metafísica do Amor e do Sofrimento do Mundo, traduzido por Pietro Nassetti, São Paulo: Editora Martin Claret, 2001.

SCHOPENHAUER, A.; Sobre O Fundamento da Moral, traduzido por Maria Lucia Oliveira Cacciola, São Paulo: Martins Fontes, 2001.

SENNET, R.; O declínio do Homem público: as tiranias da intimidade, traduzido por Lygia Araújo Watanabe, São Paulo: Companhia das letras, 1988.

SINGER, Peter; Ética Prática, traduzido por Jefferson Luís Camargo, São Paulo: Martins Fontes, 1998.

SKINNER, Quentin; As Fundações do Pensamento Político Moderno, traduzido por Renato Janine Ribeiro e Laura Teixeira Motta, São Paulo: Companhia das Letras, 1996.

SKINNER, Quentin; Liberdade antes do Liberalismo, traduzido por Raul Fiker, São Paulo: UNESP, 1999.

SPOONER, L.; Vícios Não São Crime ; traduzido por Miguel Serras Pereira, São Paulo: Aquariana, 2003.

STRAUSS, Leo y CROPSEY, Joseph; Historia de la Filosofia Política, Mexico: Fondo de Cultura Económica, 1992.

TAYLOR, C.; Argumentos Filosóficos, traduzido por Adail Ubirajara Sobral, São Paulo: Loyola, 2000.

TOCQUEVILlE, A.; O Antigo Regime e a Revolução, traduzido por Yvonne Jean, 4. ed., Brasília: Ed. Universidade de Brasília, 1997.

TZU, Sun; A Arte da Guerra, adaptação e prefácio de James Clawell, traduzido por José Sanz, 18. ed., São Paulo: Record, 1996.

VAZQUEZ, A. S.; Ética, traduzido por João Dell'Anna, 11. ed., Rio de Janeiro: Civilização Brasileira, 1989.

VOLTAIRE; O Filósofo Ignorante, traduzido por Marilena Chauí, São Paulo: Abril Cultural, 1978.

WEBBER, M.; Economia e Sociedade, v. 1 e 2, traduzido por Regis Barbosa e Karen Elsabe Barbosa, Brasília: Editora da UNB, 1999.

WITTGENSTEIN, L.; Investigações Filosóficas, traduzido por José Carlos Bruni, Coleção

Os Pensadores, $1^{\text {a }}$. Edição, São Paulo: Abril Cultural, 1975. 
WOLFF, F.; Aristóteles e a Política, traduzido por Thereza Christina Ferreira Stummer e Lygia Araújo Watanabe, São Paulo: Discurso Editorial, 2001. 